TIAGO GUGLIELMETI CORREALE

\title{
A Membrana e seus Canais: \\ Um Modelo Computacional de Neurônio
}


TIAGO GUGLIELMETI CORREALE

\section{A Membrana e seus Canais: Um Modelo Computacional de Neurônio}

Tese apresentada à Escola Politécnica da Universidade de São Paulo para a obtenção do título de Doutor em Ciências.

Área de Concentração:

Engenharia de Sistemas 


\section{A Membrana e seus Canais: Um Modelo Computacional de Neurônio}

Tese apresentada à Escola Politécnica da Universidade de São Paulo para a obtenção do título de Doutor em Ciências.

Área de Concentração:

Engenharia de Sistemas

Orientador: Professor Doutor Luiz Henrique Alves Monteiro 
Este exemplar foi revisado e corrigido em relação à versão original, sob responsabilidade única do autor e com a anuência de seu orientador.

São Paulo, de de

Assinatura do autor:

Assinatura do orientador:

Catalogação-na-publicação

Correale, Tiago Guglielmeti

A Membrana e seus canais: um modelo computacional de neurônio / T. G. Correale -- versão corr. -- São Paulo, 2017. $137 \mathrm{p}$.

Tese (Doutorado) - Escola Politécnica da Universidade de São Paulo. Departamento de Engenharia de Telecomunicações e Controle.

1.NEUROCIÊNCIAS 2.SIMULAÇÃO DE SISTEMAS 3.MODELAGEM COMPUTACIONAL 4.AUTÔMATOS CELULARES I.Universidade de São Paulo. Escola Politécnica. Departamento de Engenharia de Telecomunicações e Controle II.t. 
Dedico esta tese a Deus, meus pais, meus familiares, meu orientador e a todos os que buscam o conhecimento. 


\section{AGRADECIMENTOS}

Quero agradecer ao meu orientador, Professor Doutor Luiz Henrique Alves Monteiro, pela grande ajuda na elaboração deste trabalho. Agradeço também aos meus pais, pela grande paciência e dedicação que tiveram comigo, desde a minha infância, até o presente momento. Também quero agradecer aos membros da banca, por terem dedicado tempo e esforço na leitura deste trabalho. 
“...I am conscious of imperfection when (I look at) the scholars of (past and contemporary) times. I confess my inability to penetrate so difficult subject. I wish that men of scholarly competence and wide knowledge would look at this work with a critical, rather than a complacent eye, and silently correct and overlook the mistakes they come upon. The capital of knowledge that an individual scholar has to offer is small. Admission (of one's shortcomings) saves from censure.

Kindness from colleagues is hoped for." Abdulrahman ou Ibn Khaldun, adaptado pelo autor, no livro "Muqaddimah", 


\section{Resumo}

Modelar a dinâmica de neurônios é relevante em estudos de neurociências. Neste trabalho, propõe-se um modelo computacional de neurônio baseado no comportamento dos canais iônicos presentes na sua membrana. O modelo combina elementos microscópicos, como o comportamento dos canais individuais, com elementos macroscópicos, como a tensão ao longo de um trecho de membrana. Simulações foram realizadas com o objetivo de reproduzir dados biológicos e resultados obtidos de modelos teóricos clássicos da área. Foi possível reproduzir com boa concordância o potencial de ação, o fenômeno da adaptação, a curva da corrente de entrada versus a frequência de disparos e o potencial excitatório pós-sináptico.

Palavras-chave: autômato celular, canais iônicos, modelo matemático, neurodinâmica. 


\begin{abstract}
Modelling the dynamics of neurons is relevant in studies on neurosciences. In this work, a computational model of neuron based on the behavior of the ionic channels found in its membrane is proposed. The model comprises microscopic elements, as the behavior of the individual channels, and macroscopic elements, as the tension along a membrane patch. Simulations were performed with the aim of reproducing biological data and results derived from classical theoretical models of the field. It was possible to reproduce with good agreement the action potential, the phenomenon of adaptation, the curve of the input current versus the spike frequency, and the excitatory postsynaptic potential.
\end{abstract}

Keywords: cellular automaton, ion channels, mathematical model, neurodynamics. 


\section{Lista de Figuras}

1.1 Escalas de estudo da neurociência. . . . . . . . . . . . . . . . . 4

1.2 Posicionamento da pesquisa com relação a algumas áreas do conhecimento. 6

2.1 Permeabilidade relativa de uma camada dupla de lipídios, que funciona de forma similar a uma membrana artificial. As flechas representam o grau de permeabilidade da membrana, que pode permitir a passagem completa de algumas substâncias (como na flecha do topo), parcial (como nas duas flechas ao meio), ou ser totalmente impermeável para outras substâncias (como na flecha inferior). . . . . . . . . . . . . . . . . . . . 12

2.2 Diagrama simplificado de um neurônio e suas principais partes. . . . . . . . 25

2.3 Diagrama simplificado de uma sinapse. . . . . . . . . . . . . . . . . . . . . 27

2.4 O potencial de ação. No eixo das ordenadas tem-se a tensão do trecho de membrana, em milivolts, e no eixo das abscissas tem-se o tempo, em milissegundos. . . . . . . . . . . . . . . . . . 32

2.5 O agrupamento das vesículas sinápticas dentro do neurônio. . . . . . . . . 34

2.6 Alguns tipos de disparo de um neurônio. . . . . . . . . . . . . . . . . . . . . 35

3.1 Modelo elétrico da membrana da lula. . . . . . . . . . . . . . . . . . 39

3.2 Circuito elétrico equivalente a uma aproximação ôhmica da membrana celular de um neurônio. . . . . . . . . . . . . . . . . . . . . . . . . . . . . 41

3.3 Circuito elétrico modelando uma sinapse inibitória. . . . . . . . . . . . . . . 43

3.4 Modelo de cadeia de Markov do canal de sódio, baseado no modelo determinista de Hodgkin e Huxley, obtido inicialmente em Fitzhugh (1965) . . . . 56

4.1 Modelo do axônio e sua discretização. . . . . . . . . . . . . . . . . . . . . . 59 
4.2 Gráfico da potencial elétrico da membrana $E$ em um trecho central, utilizado para calcular $\tau_{m}$. Neste gráfico, a linha cheia corresponde aos resultados obtidos por meio da simulação do modelo proposto, enquanto os pontos identificados com um $\times$ representam os valores teóricos de acordo com o modelo de Rall. Nessa simulação, $n_{x}=80, n_{y}=5, d_{N a}=0$, e $d_{K}=0 . \quad \ldots$.

4.3 Gráfico do potencial de membrana ao longo da superfície do axônio, para o instante de tempo $t=5 \mathrm{~ms}$. Esses valores foram utilizados para a determinação de $\lambda_{m}$. Neste gráfico, a linha cheia corresponde aos resultados obtidos por meio da simulação do modelo proposto, enquanto os pontos identificados com um $\times$ representam os valores teóricos de acordo com o modelo de Rall. Os valores dos parâmetros utilizados foram os mesmos da figura (4.2).

4.4 Distribuição do potencial de membrana $E$ ao longo do axônio também em $t=5 \mathrm{~ms}$ e com os mesmos parâmetros da figura (4.2) . . . . . . . . . . .

4.5 O modelo proposto em (DESTEXHE et al., 1994). Na figura, c corresponde ao estado fechado, o corresponde ao estado aberto e i corresponde a inativado. As probabilidades de transição são determinadas pelos parâmetros $r_{1}(V), r_{2}(V), r_{3}$ e $r_{4}(V)$, sendo que os parâmetros $r_{1}, r_{2}$ e $r_{4}$ também dependem da tensão da membrana, enquanto $r_{3}$ é uma probabilidade fixa. . . . . .

4.6 Simulação do modelo proposto em (DESTEXHE et al., 1994) com os seguintes parâmetros: $a_{1}=1500 / \mathrm{s}, a_{2}=200 / \mathrm{s}, a_{4}=150 / \mathrm{s}, b=5 \mathrm{mV}$, $c_{1}=c_{2}=-27 m V, c_{4}=-65 m V$ e $r_{3}=3000 / s$. Na figura, i significa o estado inativado, c significa fechado e o significa aberto. . . . . . . . . . . .

4.7 O modelo aproximado proposto, em condições similares a figura (4.6). $\mathrm{Na}$ figura, i significa estado inativado, c significa fechado e o significa aberto.

4.8 Potencial elétrico da membrana. A linha tracejada representa o potencial elétrico no início do axônio (o estímulo, durante $t=9 \mathrm{~ms}$ até $t=21 \mathrm{~ms}$ ), enquanto a linha contínua representa o potencial elétrico no centro do axônio, em $n_{x}=80, n_{y}=5$. Além disso, $d_{N a}=30$ e $d_{K}=5 . \ldots \ldots 1$

4.9 Detalhe do potencial de ação. . . . . . . . . . . . . . . . . . . 82

4.10 Gráfico da propagação do potencial ao longo da membrana e do tempo, utilizando os mesmos valores de parâmetros da simulação da figura (4.8). .

4.11 Potencial elétrico da membrana ao longo do axônio na última iteração. Os parâmetros utilizados são os mesmos da simulação da figura (4.8). . . . . . .

4.12 Resposta do modelo em $m V$ (linha contínua) frente a diversas entradas (linha tracejada) com variação da intensidade do potencial (potenciais gradativos). 
4.13 fenômeno da adaptação no modelo proposto. Para calcular cada um dos pontos, mediu-se a diferença de tempo $\Delta t$ entre o valor máximo de dois potenciais de ação consecutivos(o período), e adotou-se como valor de frequência o inverso desse valor, $f=\frac{1}{\Delta t}$. Além disso, o axônio simulado possui um comprimento de $2000 \mu m$ e perímetro de $500 \mu m$, com $d_{N a}=6$ e

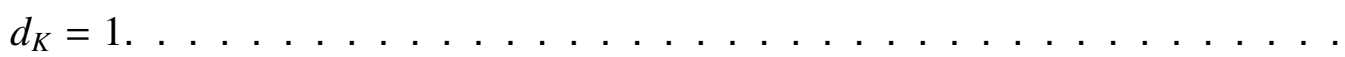

4.14 Comparação entre o modelo (linha tracejada) e dados gravados do hipocampo de ratos (linha contínua). . . . . . . . . . . . . . . .

4.15 Frequência de um neurônio de gato em função de um pulso de corrente de entrada. Os pontos foram ajustados por uma curva quadrática.

4.16 Curvas fl para os neurônios dos tipos I e II.

4.17 Comparação do intervalo entre disparos para o modelo proposto de neurônio e o modelo de Hodgkin e Huxley. . . . . . . . . . . . . . . . . . . . . . . .

4.18 Frequência de disparos do potencial de ação para o modelo modificado. Observe que para baixas correntes de entrada a frequência de disparo é pequena, subindo de forma gradual até chegar um valor máximo, o comportamento característico dos neurônios tipo-l.

4.19 Comparação dos disparos de potencial de ação no modelo proposto no presente trabalho (linha grossa) e o modelo de Hodgkin e Huxley (linha fina).

4.20 Curvas fl obtidas com o modelo proposto (representado por $\times$ ) e com o modelo de Hodgkin e Huxley (representado por •). . . . . . . . . . . . . . . . .

4.21 Curvas fl obtida com a modificação do modelo proposto, de tipo-II para tipo-I. Foi mantida a mesma escala vertical da figura (4.20) para facilitar a comparação.

5.1 Estrutura geral da zona ativa. . . . . . . . . . . . . . . . . . . 108

5.2 Comparação do potencial de membrana pós-sináptico. Na simulação, $d_{v}=$ $5 \mathrm{~nm}$ (para cada quadrado). A linha tracejada é o gráfico de uma função alfa com $\tau_{m}=660 \mu$ s enquanto a linha contínua é a média de 100 execuções do modelo. A figura corresponde apenas ao primeiro PEPS.

5.3 Zona ativa com dois canais de cálcio.

5.4 Gráfico do número de potencias excitatório pós-sináptico versus a distância $d_{v}$ entre as vesículas, para diferentes configurações de canais. . . . . . . . . 112

5.5 Agrupamento de canais iônicos de cálcio. . . . . . . . . . . . . . . . . . . . 113 
5.6 PEPS gerados por um agrupamento de canais (linha contínua) comparado com a função alfa (linha tracejada, com os mesmos parâmetros da figura (5.2)). . . . . . . . . . . . . . . . . . . . 114 


\section{Lista de Tabelas}

2.1 Concentrações iônicas dentro e fora do meio celular, para os íons de potássio, sódio e cloro. . . . . . . . . . . . . . . . . . . . . . . . 18

4.1 Descrição dos intervalos de tempo utilizado no modelo para cada tipo de canal. . . . . . . . . . . . . . . . . . . 65

4.2 Parâmetros utilizados nas simulações. . . . . . . . . . . . . . . . . 71

4.3 Comprimento eletrotônico para diversos organismos (nervos e músculos). . 75

4.4 Parâmetros utilizados para a simulação da figura (4.19) . . . . . . . . . . . . 95 


\section{Sumário}

1 Introdução 1

1.1 A neurociência na atualidade . . . . . . . . . . . . . . 2

1.2 Motivação . . . . . . . . . . . . . . . . . 7

2 Aspectos conceituais da pesquisa 9

2.1 A membrana celular . . . . . . . . . . . . . . . . . . . . . . . . . . . . . . . 10

2.1.1 A membrana celular e seus canais iônicos . . . . . . . . . . . . . . . 12

2.2 A tensão de repouso da membrana . . . . . . . . . . . . . . . . . . 15

2.3 Descrição de um canal iônico . . . . . . . . . . . . . . . . . . . . . . . . 19

2.3.1 Tipos de canais iônicos . . . . . . . . . . . . . . . . . . 21

2.3.2 A anatomia de um canal iônico: O canal de potássio . . . . . . . . . 22

2.4 O neurônio . . . . . . . . . . . . . . . . . . . . . . . . . . . . . . . . 24

2.4.1 Aspectos evolutivos dos neurônios . . . . . . . . . . . . . . . . . . 28

2.5 O potencial de ação . . . . . . . . . . . . . . . . . . . . . . . . . . . 31

2.6 Sinapses químicas e elétricas . . . . . . . . . . . . . . . . . 35

2.7 O sistema nervoso . . . . . . . . . . . . . . . . . . . . 37

3 Modelos em neurociência 38

3.1 Modelos matemáticos e computacionais em neurociência . . . . . . . . . . 38

3.2 Neurônios e circuitos elétricos . . . . . . . . . . . . . . . . . . . . . . 42

3.2.1 Considerações sobre os modelos baseados no trabalho de Hodgkin e Huxley . . . . . . . . . . . . . . . . . . . 45

3.3 Exemplos de alguns modelos em neurociência . . . . . . . . . . . . . 48

3.4 Justificativa para a estratégia utilizada . . . . . . . . . . . . . . . . . 52

3.5 A abordagem seguida no presente trabalho . . . . . . . . . . . . . . . . 53

3.6 Modelos cinéticos . . . . . . . . . . . . . . . . . . . . . . 55 
4 O modelo do axônio 58

4.1 Propondo um modelo . . . . . . . . . . . . . . . . . . . . . . . . 58

4.1.1 A origem do potencial elétrico da membrana . . . . . . . . . . . 61

4.1 .2 A dinâmica dos canais . . . . . . . . . . . . . . . . . . . 63

4.1.3 Características locais da membrana . . . . . . . . . . . . . . 66

4.1 .4 O cálculo da tensão . . . . . . . . . . . . . . . . . . . . . . 67

4.2 Resultados . . . . . . . . . . . . . . . . . . . . . . . 70

4.2.1 Simulações da membrana sem canais iônicos ativos . . . . . . . . . 71

4.2 .2 Simulação dos canais de sódio . . . . . . . . . . . . . . . . . . . . 77

4.2.3 Simulações da membrana com todos os canais . . . . . . . . . . . . 80

4.2.4 Incorporando o mecanismo de adaptação . . . . . . . . . . . . . . . 84

4.2 .5 Comparação com dados biológicos . . . . . . . . . . . . . . . . . . 87

4.3 A curva fl . . . . . . . . . . . . . . . . . . . . . . . . . . 90

4.3.1 Mudando o tipo de neurônio . . . . . . . . . . . . . . . . . . . . 93

4.3 .2 Simplificando o modelo . . . . . . . . . . . . . . . . . . . . 94

5 O modelo da sinapse $\quad 100$

5.1 A construção de um modelo de sinapse . . . . . . . . . . . . . . . . . . . . 101

5.1 .1 Definindo a resolução . . . . . . . . . . . . . . . . . . . . . . . . 102

5.2 O modelo da zona ativa . . . . . . . . . . . . . . . . . . . . . . . . . 102

5.3 A fenda sináptica . . . . . . . . . . . . . . . . . . . . 105

5.4 O lado pós-sináptico . . . . . . . . . . . . . . . . 106

5.4.1 O cálculo do potencial na membrana pós-sináptica . . . . . . . . . 106

5.5 Resultados . . . . . . . . . . . . . . . . . . . . . . . . . . . . . 108

5.5.1 Resultados para uma zona ativa simples . . . . . . . . . . . . . . . 109

6 Conclusões $\quad 115$

6.1 A utilidade de diferentes modelos . . . . . . . . . . . . . . . . 116

6.2 Algumas considerações sobre os resultados obtidos . . . . . . . . . . . . 118

6.2 .1 O modelo axonal . . . . . . . . . . . . . . . . . . . . . . . . 118

6.2.2 Curva de frequência versus corrente de entrada . . . . . . . . . . . 119

6.2 .3 Sinapses e processamento . . . . . . . . . . . . . . . . . . . . . . 119

6.3 Direções futuras de pesquisa baseadas no modelo proposto . . . . . . . . . 120

Referências Bibliográficas 122 


\section{Capítulo 1}

\section{Introdução}

The best material model of a cat is another, or preferably the same, cat.

Norbert Wiener

O objetivo da presente pesquisa é elaborar um modelo computacional de um neurônio baseado no comportamento da membrana e dos seus canais iônicos, e buscar elucidar a relação entre o comportamento microscópico dos canais iônicos e o comportamento macroscópico do neurônio. O estudo dos canais iônicos vai muito além da neurociência, sendo fundamental para a biologia celular em geral. Várias tipos de células possuem canais iônicos em sua membrana. Canais iônicos existem até mesmo em organismos unicelulares, como o paramécio (HILLE, 2001).

Para evitar distorções decorrentes da arbitrariedade na construção de modelos (sejam eles matemáticos ou computacionais), optou-se por uma abordagem iterativa e incremental. Inicialmente, buscam-se replicar os aspectos mais simples e triviais dos neurônios, adicionando-se elementos mais complexos em pequenas etapas, conforme se observa uma boa adequação do modelo com os aspectos mais básicos. Na abordagem seguida, o canal iônico funciona como base da modelagem, tendo sido criado um modelo simplificado do seu funcionamento, que é utilizado para o cálculo do potencial da membrana.

O presente texto está dividido nos seguintes capítulos:

1. Introdução e motivação do trabalho;

2. Aspectos conceituais do problema, em que se faz uma pesquisa bibliográfica dos temas relacionados, bem como um resumo dos aspectos relevantes para a pesquisa; 
3. Modelos em neurociência, em que se discutem diversas abordagens utilizadas na modelagem de neurônios;

4. O modelo do axônio, em que se descreve como o axônio foi construído, e se apresentam os resultados do modelo proposto;

5. O modelo da sinapse, em que se descreve como o modelo da sinapse foi construído, e os resultados obtidos;

6. Conclusão, na qual são feitas as considerações finais obtidas com o presente trabaIho, bem como são feitas sugestões de continuação da abordagem apresentada;

7. Referências bibliográficas utilizadas.

\subsection{A neurociência na atualidade}

Devido à dificuldade gigantesca em entender o cérebro (mesmo que não necessariamente o cérebro humano), os neurocientistas costumam dividir a sua análise em diferentes níveis de detalhes, partindo de um nível mais fundamental até um nível mais global. Seguindo a abordagem de Bear et al. (2007), porém com algumas alterações, podem-se definir os seguintes níveis de pesquisa:

1. O nível molecular: nesse nível, busca-se compreender o comportamento das moléculas e íons que atuam no sistema nervoso, tanto de forma direta (ou seja, uma molécula ou íon afetando o funcionamento de um único neurônio) como de forma indireta (influenciando outras moléculas ou células que por sua vez podem alterar o funcionamento de outros neurônios ou do sistema nervoso).

2. O nível celular: estudam-se especialmente os neurônios bem como as diversas outras células que fazem parte do sistema nervoso. Nesse caso, o modelo situa-se um nível acima do anterior, e seu objetivo é compreender qual é o papel de um tipo específico de célula (dado um contexto) e descrever seu funcionamento (normal ou defeituoso), bem como suas consequências. Ainda que o foco permaneça no funcionamento de uma única célula, um número maior de fatores é levado em consideração. 
3. O nível sistêmico: busca-se o entendimento de mais de uma célula e não de apenas um único neurônio, mas de um conjunto de neurônios ${ }^{1}$. Procura-se entender a organização de um conjunto de células, e como essa organização dá origem a diversas funções, como por exemplo (no caso do cérebro humano): o sistema visual, o motor, entre outros. Também procura-se entender como um conjunto de neurônios recebe, processa e integra informações vindas de outras áreas do cérebro e do meio externo.

4. O nível comportamental: nesse nível, estuda-se como o sistema nervoso dá origem ao comportamento. Busca-se entender a relação entre o comportamento observado de um animal (por exemplo, o comportamento de fuga) e o seu cérebro. Frequentemente, observa-se um grau de especialização no cérebro, em que áreas específicas têm uma correlação direta com certos comportamentos. Entretanto, deve-se ter cautela ao atribuir uma "função" específica para uma área, dado que o cérebro (bem como os outros órgãos) é resultado de um processo evolutivo contínuo: ao contrário de um mecanismo artificial, em que cada parte tem uma "função específica", como as partes de um carro ou de um computador, no cérebro humano cada área influencia as demais, e muitas vezes de formas sutis (MCGILCHRIST, 2009). É perigoso utilizar uma abordagem excessivamente reducionista, atribuindo funções únicas às partes, como faríamos com uma máquina (ou um sistema artificial/sintético, que foi projetado de forma reducionista).

5. Finalmente, no nível cognitivo, busca-se entender aspectos muito mais complexos e sofisticados, como o funcionamento da mente, a consciência e a linguagem. Essencialmente, busca-se a resposta da pergunta: como o cérebro cria a mente?

1 Uma brincadeira entre cientistas da área diz que o estudo de um único neurônio é o domínio da neurociência, enquanto o estudo de mais de um neurônio é o domínio da psicologia. 
Figura 1.1: Escalas de estudo da neurociência.

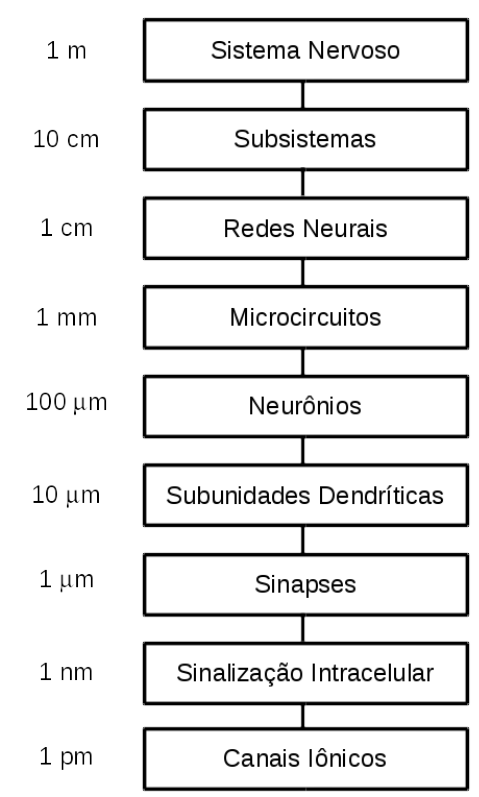

Fonte: Adaptado de Sterratt et al. (2011).

Uma outra possível abordagem é a de se pensar em uma divisão de níveis baseada na dimensão física das interações. Nessa caso, pensa-se em uma escala dimensional, começando no nível atômico (em uma escala de ordem de $1 \mathrm{pm}$ ) até o nível mais elevado (da ordem de $1 \mathrm{~m}$, ou do tamanho do organismo sendo estudado), como podemos ver na figura (1.1), adaptada de Sterratt et al. (2011).

Por ser uma ciência essencialmente multidisciplinar, a neurociência se beneficia de várias áreas do conhecimento, como a medicina, a psicologia, a biologia, a bioquímica, a física, a matemática, a computação e a engenharia. A presente pesquisa pode ser vista tanto como uma contribuição da área de sistemas dinâmicos quanto da computação, resultando no que costuma ser chamado de neurociência computacional. O interrelacionamento entre cada uma dessas áreas é bastante forte, sendo difícil estabeler uma fronteira clara. Observa-se essa diversidade de pontos de vista na literatura da área, em que podem ser encontrados livros com foco mais matemático, como os livros de Gabbiani et al. (2010) e Izhikevich (2007), sendo que o último poderia ser considerado um excelente livro introdutório também para área de sistemas dinâmicos. Outros livros focam em aspectos computacionais e na construção de modelos, como o livro de Sterratt et al. (2011). Os tradicionais livros da área normalmente são os utilizados nos cursos de medicina e outros 
cursos da área de biologia, como os livros de Kanldel et al. 2012 e Bear et al. 2007, que focam muito mais em uma descrição qualitativa do que quantitativa da neurociência ${ }^{2}$.

Adicionalmente, deve-se ressaltar que muitos dos objetivos da neurociência atual são similares aos da cibernética, termo que nos últimos anos, infelizmente, não vem sendo muito utilizado. Wiener (1965), em seu livro clássico sobre cibernética, já destacava muitos problemas que atualmente se associam com a neurociência ${ }^{3}$.

A multidisciplinaridade da área torna difícil até mesmo a classificação de alguns livros, como os livros de Koch e Segev (1998) e Koch (1999), que podem ser classificados tanto como da área da física ou da matemática (além de serem, naturalmente, trabalhos associados com a neurociência). A necessidade de conhecer vários conceitos da área de engenharia elétrica, como o cálculo de correntes e tensões e o relacionamento com diversos aspectos da teoria de controle, mostra a interdisciplinaridade inerente da neurociência. Em um nível macroscópico, especialmente quando se trata dos aspectos cognitivos, a psicologia e a filosofia são muito úteis, como pode ser observado em trabalhos como os de O’Reilly e Munakata (2000), em que se exploram modelos computacionais na área cognitiva, e livros como o de Bechtel (2008), que explora alguns aspectos filosóficos da neurociência. Um artigo publicado no periódico Reviews of Modern Physics procura ressaltar como as áreas de sistemas dinâmicos e a neurociência se relacionam e se complementam (RABINOVICH et al., 2006). Além disso, outras áreas também se beneficiam do conhecimento da neurociência. Por exemplo, uma nova área da filosofia foi proposta por P.S. Churchland, a chamada neurofilosofia, que aplica conhecimentos vindos da neurociência na filosofia (em específico na epistemologia) (CHURCHLAND, 1989, 2002). Na figura (1.2), há um diagrama que ilustra o posicionamento do presente trabalho.

2 Contudo, observa-se uma tendência no uso de métodos quantitativos na área, como pode ser observado no livro de (KANDEL et al., 2012).

3 O autor vê na cibernética uma ferramenta fundamental para a neurociência, e gostaria que este trabalho fosse visto como uma tentativa de utilização dessa abordagem. 
Figura 1.2: Posicionamento da pesquisa com relação a algumas áreas do conhecimento.

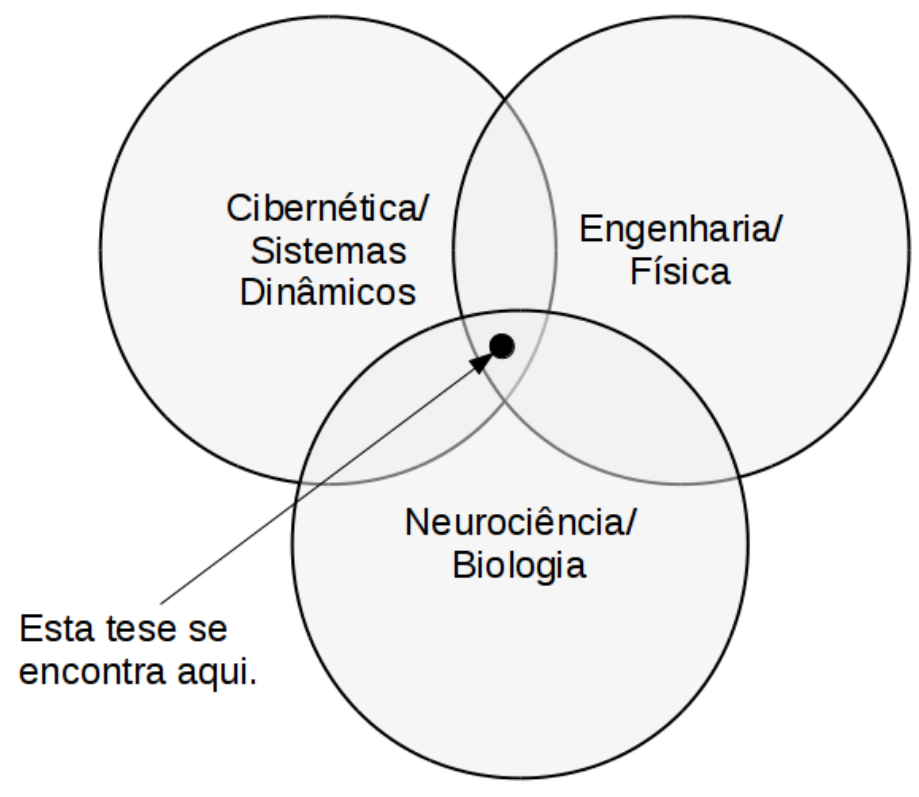

Fonte: Autor.

Atualmente existe um esforço muito grande na construção de modelos computacionais realistas de neurônios e de redes neurais ${ }^{4}$. Um dos exemplos mais notáveis é o chamado Blue Brain Project5(MARKRAM, 2006), com a participação de diversos países europeus. Originalmente, esse projeto consistiu na simulação de uma coluna do neocórtex do rato, contendo aproximadamente 10000 neurônios e $10^{8}$ sinapses. O projeto conta com vários cientistas e supercomputadores, e envolve um orçamento elevado. Hoje o projeto vem sendo direcionado na tentativa de simulação de um cérebro completo de um ser humano.

Do outro lado do Atlântico vem sendo desenvolvido um outro projeto, similar, chamado de BRAIN project ${ }^{6}$ (ALIVISATOS et al., 2012). O projeto foi oficialmente lançado em 2012. A abordagem é um pouco diferente do projeto europeu: existe uma grande ênfase em desenvolver novas tecnologias que auxiliem nas pesquisas na área da neurociência ${ }^{7}$.

Porém, deve-se observar que também é possível fazer pesquisas relevantes na área de neurociência com orçamentos pequenos, como, por exemplo, os trabalhos do neurocientista V. Ramachandran, ilustrados no livro Phantoms in the Brain (RAMACHANDRAN,

\footnotetext{
4 No presente trabalho, o termo rede neural tem a conotação de rede neuronal, ou seja, uma rede de neurônios ou uma rede artificial neural com o objetivo de ser um modelo realista de uma rede neural biológica.

5 O site do projeto pode ser acessado em http://bluebrain.epfl.ch/.

6 O site do projeto é http://www.braininitiative.nih.gov/index.htm .

7 O que pode dar origem a novos produtos.
} 
1998). Muitas vezes, com aparelhos simples (como uma caixa com espelhos), ideias sobre o funcionamento do cérebro podem ser testadas (dado que se disponha de pacientes com problemas neurológicos específicos). As doenças neurológicas dão pistas da forma como o cérebro está estruturado, sendo historicamente uma importante fonte de informação. O linguista S. Pinker argumenta que a linguagem (bem como as diversas patologias associadas à linguagem) é uma espécie de janela para o cérebro ${ }^{8}$, e muitos de seus livros ilustram os aspectos evolutivos da linguagem (PINKER, 1995). Para cientistas cognitivos e alguns neurocientistas, até mesmo um simples texto pode ser um instrumento para a neurociência, como pode ser visto no artigo de Bedi et al. (2015).

Outro ponto que deve ser ressaltado em qualquer pesquisa científica que envolva a construção de modelos é o grau de complexidade versus o grau de realismo empregado na modelagem. Esse é um aspecto fundamental: frequentemente, o aumento no realismo de um modelo implica um aumento da sua complexidade, seja na sua sofisticação ou na sua complexidade computacional. Por outro lado, modelos muito complexos podem ser difíceis de serem compreendidos. Talvez exista um ponto ótimo entre complexidade e utilidade: modelos muito simples (ou simplistas) podem ser considerados inúteis, apenas reafirmando o que já se sabe, enquanto modelos muito complexos podem perder o caráter explicativo, e em vez de auxiliarem o entendimento, tornam-se uma peculiaridade científica.

\subsection{Motivação}

A motivação deste trabalho vem da necessidade, especialmente na neurociência, em se obter modelos que sejam simples e úteis. Essa é uma abordagem seguida em outras áreas do conhecimento, como por exemplo na área de Vida Artificial (LANGTON, 1997), na qual busca-se compreender os princípios genéricos que organizam a vida, em vez de se ter um foco em mecanismos específicos. Essa abordagem pressupõe que tais princípios efetivamente existam, o que significa dizer que a vida é baseada em princípios que podem ser identificados, estudados e generalizados a partir dos exemplos que existem ao nosso redor.

Se, por outro lado, supusermos que essa premissa não se sustenta, e que não exista nenhuma generalização possível, então pode-se dizer que o trabalho dos cientistas, especialmente daqueles envolvidos nas chamadas ciências complexas (MONTEIRO, 2011; SAYAMA, 2015) está profundamente comprometido. Por mais fatos que coletem, nessas

8 O vídeo https://www.youtube.com/watch?v=Q-B_ONJIEcE, apresentado pelo próprio Steven Pinker, tem o título Linguistics as a Window to Understanding the Brain. 
circunstâncias não seria possível obter uma teoria que permita entender como esses fatos se relacionam. Dessa forma, todos os detalhes seriam necessários para entender um organismo, nada seria contingente e não se poderia abstrair nenhum padrão de organização.

Por outro lado, supondo que realmente existam princípios fundamentais que organizam a vida, então uma tarefa da ciência é a de identificar esses princípios. A natureza está repleta de instâncias desses princípios. Essas instâncias possuem detalhes que caracterizam como um organismo se adaptou a um ambiente em particular. Mas em meio a esses detalhes, existem princípios básicos de organização. Pode-se dizer que esse é o papel do cientista teórico: buscar nos fatos os elementos que caracterizam a melhor abstração possível, levando a uma teoria que seja plausível, realista e que possa ser entendida. São dos fatos que nasce a teoria. E é da teoria que nasce o conhecimento. O cientista tece o conhecimento a partir dos fatos.

Nessa tese, desenvolve-se um modelo de neurônio baseado no comportamento dos canais iônicos presentes em sua membrana. O modelo proposto é bastante simplificado, especialmente com relação à modelagem dos canais iônicos. Porém, ao se construir modelos e ao se investigar como esses se comportam em comparação com os dados de laboratório, podem-se contextualizar os fatos científicos de uma forma mais clara, auxiliando no entendimento. Os modelos podem ser artificiais, mas como os outros trabalhos na área, sua utilidade não está em substituir a realidade, mas sim em ajudar a entendê-la. 


\title{
Capítulo 2
}

\section{Aspectos conceituais da pesquisa}

Cognitive psychology has shown that the mind best understands facts when they are woven into a conceptual fabric, such as a narrative, mental map, or intuitive theory. Disconnected facts in the mind are like unlinked pages on the Web: They might as well not exist.

Steven Pinker

Uma das abordagens para se criar um modelo válido de um neurônio consiste em compreender, em detalhes, seu funcionamento do ponto de vista molecular e bioquímico. Devido à enorme complexidade da células neuronais, e da enorme quantidade de interações físicas e químicas envolvidas no seu funcionamento, é notável que uma célula dessa natureza seja capaz de manter o seu funcionamento de forma tão organizada e robusta durante décadas. Pode-se dizer ainda que o comportamento do neurônio é um fenômeno emergente, decorrente de um processo da auto-organização dos elementos que compõem a célula. Aqui, utiliza-se a ideia de auto-organização como definida por Camazine (2003) ${ }^{1}$ :

\begin{abstract}
A auto-organização é um processo no qual um padrão no nível global de um sistema emerge apenas devido às diversas interações dos seus componentes nos níveis inferiores. Além disso, as regras que especificam as interações entre os componentes do sistema devem ser executadas utilizando apenas informações locais, sem uma referência direta ao padrão global.
\end{abstract}

$\overline{1}$ O autor da tese traduziu o texto do inglês para português, sendo o texto original em inglês. 
Essa ideia não é nova. Nos trabalhos de Ashby, um dos fundadores da Cibernética, no livro Design for a Brain (ASHBY, 1954), citam-se três aspectos para que um sistema possa ter adaptação:

1. O sistema deve conter muitas variáveis que possam se comportar como funções binárias;

2. o sistema deve conter funções-partes²;

3. o sistema deve ser construído, pelo menos em parte, de forma aleatória, de maneira que o seu comportamento seja determinado não individualmente, mas estatisticamente.

Deve-se observar que esse livro faz parte de trabalhos pioneiros na área de cibernética, feitos ainda no final da década de 50 do século XX. Porém, claramente, o livro faz alusão ao comportamento do todo como sendo um fenômeno emergente das partes interconectadas. A presente tese segue uma abordagem similar, contudo, aqui o foco é ainda mais microscópico: busca-se simular o comportamento do neurônio a partir da caracterização das suas partes, especificamente os canais iônicos.

Para isso, deve-se inicialmente buscar entender o funcionamento da membrana celular do neurônio, uma vez que o comportamento dos neurônios é, em grande parte, mediado pela sua membrana, e também porque é nela que os canais iônicos estão presentes ${ }^{3}$. A partir do funcionamento dos canais (e de acordo com a sua diversidade), pode-se investigar o comportamento do neurônio, comparando-se o comportamento do modelo com os dados publicados na literatura da área. Nas próximas seções, faz-se um pequeno resumo das características biofísicas da membrana relevantes para o presente trabalho.

\subsection{A membrana celular}

It is notoriously difficult to define the word living.

Francis Crick

2 Por funções-partes, Ashby se refere à ideia de que partes do sistema devem possuir um grau de equilíbrio e robustez em relação a perturbações ao sistema como um todo, próximo da ideia que modernamente se chama de atrator.

3 Também existem canais iônicos em algumas organelas citoplasmáticas, que também contribuem para o funcionamento do neurônio (ALBERTS et al., 2008). 
Ao menos na vida como conhecida no planeta Terra, as células de todos os organismos definidos como vivos ${ }^{4}$ precisam estar definidas e separadas do meio exterior por algum tipo de membrana, ou algo capaz de separar o interior do exterior da célula e também proteger e definir seus limites ${ }^{5}$. A membrana citoplasmática faz esse papel, mas faz também muito mais do que ser apenas uma simples parede. Além de funcionar como elemento estrutural e protetor, sua constituição físico-química permite um funcionamento sofisticado, sendo ao mesmo tempo um meio para a difusão bidimensional de substâncias e de informações, uma barreira seletiva, e, no caso dos neurônios, atuando como um elemento computacional. Muito se fala sobre a genética e sobre suas implicações, mas frequentemente se ignora a importância da membrana, que pode ter sido o primeiro elemento constituinte da (ou talvez das) primeira(s) célula(s), ou um dos seus primeiros elementos a possibilitarem um metabolismo complexo (LOVEJOY, 2005; EDWARDS, 1998).

A ideia de que as membranas podem ser consideradas um elemento computacional é relativamente recente, mas vem atraindo a atenção de pesquisas na área de ciência da computação (especificamente na área de computação com membranas ou sistemas- $P$ (PĂUN; ROZENBERG, 2002)). Além disso, pode-se ainda ver a computação com membranas como um paradigma de modelagem de uma célula, ou mesmo da sua estrutura interna, uma vez que nos organismos eucariontes, as organelas citoplasmáticas internas ao meio celular são frequentemente envolvidas por membranas, que possuem um papel fundamental no comportamento da célula como um todo. As mitocôndrias e o núcleo da célula são exemplos clássicos desse aspecto. Na computação com membranas, as membranas formam uma espécie de hierarquia computacional e pode-se perguntar se o mesmo não ocorre em uma célula biológica real.

De um ponto de vista evolutivo, as membranas definiram as fronteiras entre os organismos, mas impuseram também uma necessidade de detecção e/ou comunicação, uma vez que criaram uma barreira entre o meio externo e o meio interno. Além disso, muitos resíduos do metabolismo celular devem ser periodicamente removidos do interior da célula, exigindo algum mecanismo de excreção. Esses "problemas" tiveram que ser resolvidos por meio de diversos mecanismos de troca de substâncias entre o meio interno e o meio externo, e esses mecanismos tiveram que se tornar cada vez mais precisos, sendo capazes de identificar quais elementos devem ser excretados, quais elementos devem ser absorvidos e quais elementos devem ser mantidos do lado de dentro ou do lado de fora

4 Existem várias definições possíveis de vida, e não se quer entrar no debate da sua definição. Aqui entende-se como organismos vivos os procariontes e os eucariontes, e exclui-se os vírus e os príons.

5 Especialmente no caso de um organismo unicelular. 
da célula. Essa elevada seletividade na permeabilidade da membrana celular vai ser um aspecto recorrente no decorrer da presente pesquisa.

\subsubsection{A membrana celular e seus canais iônicos}

A membrana celular consiste em uma dupla camada de lipídios na qual diversas proteínas estão embutidas (ALBERTS et al., 2008). Devido à sua constituição química, essa camada possui permeabilidade seletiva: permite a passagem de algumas substâncias, sendo impermeável para muitas outras.

Dessa forma, a membrana celular provê um elevado grau de isolamento e proteção, mas é necessário algum mecanismo adicional para possibilitar a troca de moléculas entre o interior e o exterior da célula. Os canais iônicos constituem um desses mecanismos.

Figura 2.1: Permeabilidade relativa de uma camada dupla de lipídios, que funciona de forma similar a uma membrana artificial. As flechas representam o grau de permeabilidade da membrana, que pode permitir a passagem completa de algumas substâncias (como na flecha do topo), parcial (como nas duas flechas ao meio), ou ser totalmente impermeável para outras substâncias (como na flecha inferior).
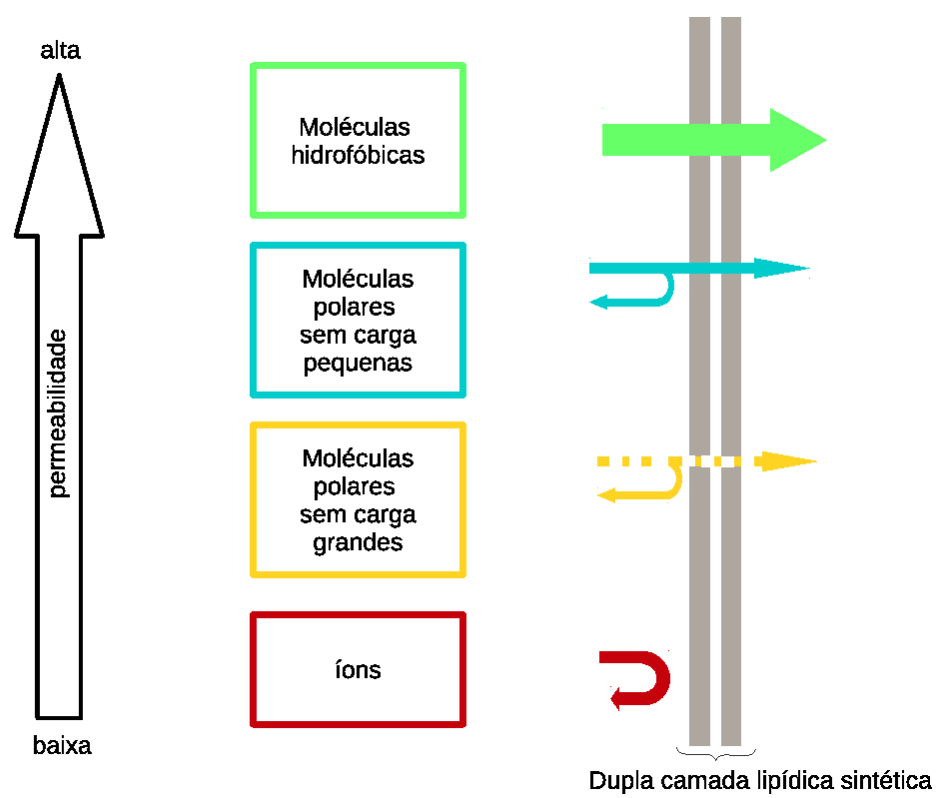

Fonte: Adaptado de Alberts et al. (2008).

A figura (2.1) ilustra um exemplo da permeabilidade relativa de diversas substâncias em uma camada dupla de lipídios, sintética, essencialmente uma membrana artificial. Em diversos experimentos feitos com membranas artificiais, observa-se que a permeabilidade da membrana é muito baixa para íons, mas é bastante elevada para moléculas hidrofóbi- 
cas. A membrana celular também é bastante permeável para gases como o gás oxigênio e para o dióxido de carbono. É importante observar que a membrana em si é formada por moléculas que possuem um lado hidrofóbico e outro lado hidrofílico. Dessa forma, moléculas hidrofóbicas têm facilidade em se difundir na membrana, enquanto substâncias hidrofílicas têm dificuldade ${ }^{6}$.

As pesquisas feitas com membranas biológicas reais (não sintéticas) obtiveram resultados similares às pesquisas feitas com membranas artificiais (ALBERTS et al., 2008), confirmando as expectativas.

Para resolver o "problema" da permeabilidade das membranas, permitindo a entrada e saída de substâncias úteis de dentro da célula, uma série de canais, constituídos por proteínas, estão embutidos na membrana. Essas proteínas provêm um caminho para a entrada e saída de certos íons e moléculas de dentro da célula. Contudo, é fundamental que essas proteínas tenham um elevado grau de seletividade, sendo permeáveis somente a certas substâncias, mas não às demais. O mundo exterior da célula pode estar repleto de substâncias tóxicas ou mesmo de outros organismos que podem querer se aproveitar dos recursos de uma célula viva. Ao prover um caminho extremamente específico para a entrada de substâncias para dentro da célula, as proteínas da membrana permitem que uma célula seja capaz de manter seu equilíbrio e se alimentar sem ter que lidar com substâncias nocivas vindas do meio (pelo menos de um ponto de vista ideal: evidentemente, alguns organismos parasitas podem ser capazes de driblar essa barreira, como é o caso dos vírus (WAGNER et al., 2009)).

Dessa forma, é possível afirmar (de forma simplificada ${ }^{7}$ ) que se os lipídios constituem a base estrutural das membranas, e as proteínas dão à membrana seu aspecto funcional (ALBERTS et al., 2008). Dentre as diversas proteínas que constituem a membrana, destacam-se os canais iônicos, que estão diretamente ligados ao estabelecimento do potencial de membrana(ALBERTS et al., 2008; MILLER, 2000; HILLE, 2001).

Ainda que a neurociência seja uma das grandes beneficiadas no entendimento do funcionamento dos canais iônicos, especialmente por causa da bioquímica dos neurônios, no qual os canais são absolutamente essenciais, o estudo dos canais tem uma importância muito mais ampla. Canais iônicos podem ser encontrados em todos os tipos de células de organismos multicelulares (BREHM et al., 1991; HILLE, 2001), em todos tipos de organismos, inclusive unicelulares, procariontes ou eucariontes (ANDERSON; GREENBERG, 2001; BREHM et al., 1991; STRONG et al., 1993; RANGANATHAN, 1994; HILLE, 2001).

6 Lembrando a regra da química: semelhante dissolve semelhante.

7 Lipídios também podem ter aspectos funcionais, sendo essa afirmação uma generalização simplificada da realidade. 
Por exemplo, em organismos unicelulares, como o paramécio, os canais permitem que este seja capaz de identificar uma colisão com um objeto, fazendo com que ele nade no sentido contrário (HILLE, 2001). Em plantas como a Mimosa, os canais permitem que esta feche as suas folhas em resposta ao toque (HILLE, 2001). Nos mamíferos, os canais possuem funções não apenas em células com membrana excitáveis, mas também em não excitáveis como os hepatócitos (células do fígado), células exócrinas das glândulas lacrimais, parótidas e fibroblastos (BREHM et al., 1991). Estudos fisiológicos em células não neurais indicam que os canais podem ter diversas funções, como regulação osmótica, secreção, mobilidade, morfogênese, mitogênese e recepção sensorial (BREHM et al., 1991).

Nas células cuja membrana é excitável, os canais iônicos afetam a tensão da membrana (a diferença de potencial entre o interior e o exterior da célula) por meio da sua abertura (ou fechamento), permitindo a passagem seletiva de íons, que por sua vez afetam a diferença de potencial. Por outro lado, o potencial de membrana também pode afetar o comportamento de alguns canais, que podem se abrir ou fechar baseado na tensão da membrana. Dessa forma, os canais tanto podem ser promotores das mudanças no potencial de membrana, como também podem ser influenciados pelo potencial. Além disso, outros fatores (como interações químicas e até mesmo mecânicas) também afetam a abertura e fechamento dos canais iônicos.

Nas chamadas células $\beta$ do pâncreas, a concentração da glicose influencia a abertura de canais iônicos, gerando atividade elétrica na membrana da célula. Devido a essa atividade, canais de cálcio se abrem na célula, permitindo a entrada desses íons. O cálcio estimula a produção e a secreção da insulina por essas células (MACDONALD; RORSMAN, 2006). Nas células musculares, a atividade dos canais iônicos está diretamente relacionada à contração a ao relaxamento, dando origem aos movimentos (BEAR et al., 2007).

Nos neurônios, os canais desempenham um papel essencial: eles permitem que seja gerado o potencial de ação, que por sua vez possibilita a comunicação entre as diversas células do sistema nervoso (ALBERTS et al., 2008; BEAR et al., 2007; KANDEL et al., 2012). Nos axônios, os canais permitem que o potencial de ação seja gerado e se propague de forma confiável por distâncias que podem chegar a mais de um metro (BEAR et al., 2007; STERRATT et al., 2011). Nas sinapses, os canais permitem que diversas substâncias interajam entre si, dando origem a comportamentos não lineares e características computacionais (ABBOTT; REGEHR, 2004; PELAEZ; ANDINA, 2013). 
No artigo que deu origem ao Prêmio Nobel de química de 2003 (DOYLE et al., 1998), MacKinnon e seus colegas mostram que as dimensões de um canal de potássio são da ordem de apenas alguns ångströms (a cavidade interna tem apenas $10 \AA$ ). Essencialmente, estamos diante de nanotecnologia funcional, no cotidiano. Portanto, o entendimento do funcionamento dos canais também podem nos dar pistas de como construir dispositivos de tamanho nanométrico. Certamente, a engenharia tem muito o que aprender com a biologia.

\subsection{A tensão de repouso da membrana}

A maioria das membranas dos organismos vivos possui uma tensão de repouso diferente de zero, o que significa que existe uma diferença de potencial entre o interior e o exterior da célula (ALBERTS et al., 2008; BEAR et al., 2007; KANDEL et al., 2012). Normalmente essa diferença é negativa, e é originada pelo acúmulo de ânions negativamente carregados (normalmente moléculas grandes) dentro da célula. Já os cátions, que inicialmente acompanhavam essas moléculas, são normalmente íons simples, pequenos, que podem trafegar pelos canais de um lado para outro da célula.

Mesmo antes da descoberta dos canais iônicos, já se conheciam alguns fatos sobre o funcionamento das membranas biológicas. Contudo, não se conheciam os mecanismos exatos que permitem o tráfego dos íons através da membrana celular. Os primeiros modelos costumavam supor que a membrana era de alguma forma semipermeável aos íons, e que esse transporte era feito por algum tipo de molécula que transportava os íons de um lado para o outro da membrana. Pode-se perceber esse tipo de pensamento nos artigos originais de Hodgkin e Huxley (1952), que sugeria, baseado em alguns experimentos, que essa visão poderia estar incorreta (provavelmente, foi a partir desses questionamentos que surgiu a ideia dos canais iônicos).

Para testar a hipótese dos canais, pode-se fazer um experimento em que se constrói uma membrana artificial e nela se inserem algumas proteínas (especificamente, proteínas que vão formar os canais iônicos). Se todos os canais estiverem abertos e permitirem a passagem de íons em ambas as direções, pode-se utilizar essa membrana para dividir um compartimento em duas partes. Inicialmente, cada um dos lados deve ser preenchidos com soluções que contenham concentrações específicas. Em um dos lados do compartimento, podem-se ter íons de sódio, potássio e cloro, com as mesmas concentrações encontradas no interior de uma célula. No outro lado, há os mesmos íons com as concentrações como no exterior da célula. Dessa forma, os íons contidos em qualquer um 
dos dois lados da membrana sofrem a atuação de dois fenômenos: a difusão, que tende a fazer com que os íons se espalhem para equalizar o gradiente de concentração, e a força elétrica, que tende a fazer com que íons tendam a atrair outros íons ou substâncias com carga oposta, e se deslocar de acordo com a diferença de potencial elétrico (e o sinal da sua carga). Costuma-se modelar esses fenômenos como duas forças, que no caso do experimento estão em sentidos opostos. Essas duas forças podem chegar a um equilíbrio, fazendo com que em média nenhuma carga atravesse a membrana (e portanto a corrente elétrica seja nula). Esse cenário define o potencial de equilíbrio da célula ${ }^{8}$.

Segue-se agora a abordagem descrita no livro de Johnston e Wu (1995), em que se obtém a equação inicialmente derivada por Goldman, Hodgkin e Katz, chamada de "equação de corrente de Goldman-Hodgkin-Katz (GHK)". Para isso, deve-se levar em consideração a contribuição de ambos os tipos de correntes (ou, de forma mais correta, da densidade de corrente) para um dado íon.

Considerando $D_{X}$ como sendo o coeficiente de difusão, $[X]$ como sendo a concentração do íon arbitrário $\mathrm{X}$ e $x$ como sendo a coordenada da posição do íon (considerando uma situação simplificada unidimensional), pode-se utilizar a lei de Fick para calcular a difusão:

$$
J_{X, d i f}=-D_{X} \frac{d[X]}{d x}
$$

obtendo o fluxo da difusão $J_{X, \text { dif }}$.

Agora, deve-se levar em conta a força elétrica, ou seja, a lei de Ohm:

$$
J_{\text {Ohm }}=\partial_{e l} E=-\mu z[X] \frac{\partial V}{\partial x}
$$

sendo $\partial_{e l}$ a condutividade elétrica, $E$ é campo elétrico, $V$ o potencial elétrico, $\mu$ a mobilidade, $z$ a valência do íon, e $[X]$ a concentração do íon $X$.

Ainda é necessário calcular a relação entre a difusão e a mobilidade, modelada inicialmente por Einstein (1905), dando origem à seguinte relação:

$$
D_{X}=\frac{k T}{q} \mu
$$

sendo que $k$ é a constante de Boltzmann em $J / K, T$ é a temperatura absoluta em Kelvins, $q$ é a carga da molécula em coulombs e $\mu$ é a mobilidade em $\frac{\mathrm{cm}^{2}}{V \cdot \mathrm{seg}}$ (JOHNSTON; WU, 1995)

8 Localmente pode existir uma corrente passando de um lado ou para outro da célula, mas a corrente líquida ou média passando por toda a membrana é nula. 
Como hipóteses, assume-se que os íons cruzam a membrana de forma independente (também chamado de princípio da independência); que existe uma conservação aproximada de cargas (exceto na região da membrana); e que o campo elétrico é constante dentro da membrana (JOHNSTON; WU, 1995). Considerando agora a contribuição tanto da difusão quanto da atração (ou repulsão) elétrica, obtém-se a chamada equação de Nernst-Planck:

$$
J=J_{\text {Ohm }}+J_{d i f}=-\mu z[X] \frac{\partial V}{\partial x}-D_{X} \frac{\partial[X]}{\partial x}
$$

em que os símbolos têm os mesmos significados descritos nos parágrafos anteriores.

Agora, substituindo o coeficiente de difusão $D_{X}$ em função da mobilidade, de acordo com a relação de Einstein, obtém-se:

$$
J=J_{\text {ohm }}+J_{d i f}=-\left(\mu z[X] \frac{\partial V}{\partial x}+\frac{\mu k T}{q} \frac{\partial[X]}{\partial x}\right)
$$

Dividindo (2.5) pelo número de Avogrado $N_{A}$, pode-se obter uma equação na forma molar:

$$
J=-\left(u z[X] \frac{\partial V}{\partial x}+\frac{u R T}{F} \frac{\partial[X]}{\partial x}\right)
$$

em que $R$ é a constante universal dos gases $\left(8,314 \frac{\mathrm{J}}{\mathrm{mol} \cdot \mathrm{K}}\right), F$ é a constante de Faraday $\left(9,648 \times 10^{4} \frac{\mathrm{C}}{\mathrm{mol}}\right), T$ é a temperatura em Kelvins e $u=\frac{\mu}{N_{A}}$ é chamada de mobilidade molar em $\left(\frac{\mathrm{cm}^{2}}{V \cdot s e g \cdot m o l}\right)$ (STERRATT et al., 2011; JOHNSTON; WU, 1995).

Nesse ponto, podem ser obtidas duas relações importantes. Considerando uma condição de equilíbrio, em que não existe corrente passando na membrana ${ }^{9}$, encontra-se a equação de Goldman-Hodgkin-Katz para tensão (STERRATT et al., 2011). Para isso, basta considerar a corrente ${ }^{10}$ nula em (2.6), obtendo:

$$
u z[X] \frac{\partial V}{\partial x}=-\frac{u R T}{F} \frac{\partial[X]}{\partial x}
$$

ou:

$$
\frac{\partial V}{\partial x}=-\frac{R T}{[X] z F} \frac{\partial[X]}{\partial x}
$$

Agora, fazendo uma mudança de variável, pode-se resolver a integral:

$$
\int_{V_{1}}^{V_{2}} d V=-\frac{R T}{z F} \int_{[X]_{1}}^{[X]_{2}} \frac{d[X]}{[X]}
$$

\footnotetext{
9 Lembrando, porém, que na realidade sempre existe um certo movimento de íons.

10 Ou a densidade de corrente.
} 
Em (2.9), $V_{1}$ é a tensão de equilíbrio na membrana (também chamada de $E_{m}$ ), $V_{2}=0$ é a tensão externa (normalmente assumida como nula) e $[X]_{1}$ é a concentração do íon $X$ interna, enquanto $[X]_{2}$ é a concentração externa. Dessa forma, resolvendo essa equação para um íon arbitrário $X$, obtém-se:

$$
E_{m}=\frac{R T}{z_{X} F} \ln \frac{[X]_{e x t}}{[X]_{\text {int }}}
$$

Por exemplo, considerando apenas os íons de potássio, sódio e cloro, pode-se obter a tensão de equilíbrio (repouso) da membrana para esses três íons da seguinte forma:

$$
E_{m}=\frac{R T}{F} \ln \frac{P_{K}\left[K^{+}\right]_{e x t}+P_{N a}\left[\mathrm{Na}^{+}\right]_{e x t}+P_{C l}\left[\mathrm{Cl}^{-}\right]_{i n t}}{P_{K}\left[K^{+}\right]_{i n t}+P_{N a}\left[\mathrm{Na}^{+}\right]_{i n t}+P_{C l}\left[\mathrm{Cl}^{-}\right]_{e x t}}
$$

em que $P_{K}, P_{N a}$ e $P_{C l}$ correspondem às permeabilidades da membrana para os íons de $\mathrm{K}^{+}, \mathrm{Na}^{+}$e $\mathrm{Cl}^{-}$(STERRATT et al., 2011).

Porém, resolvendo a equação (2.6) para uma corrente arbitrária $I_{X}$ diferente de zero, encontra-se a equação de Goldman-Hodgkin-Katz para a corrente (STERRATT et al., 2011; JOHNSTON; WU, 1995):

$$
I_{X}=P_{X} z_{X} F \frac{z_{X} F V}{R T}\left(\frac{[X]_{i n t}-[X]_{e x t} e^{-\frac{z X F V}{R T}}}{1-e^{-\frac{z X F V}{R T}}}\right)
$$

As equações (2.11) e (2.12) são chamadas de equações de campo constante devido ao fato de que uma das hipóteses para a sua dedução é que o campo elétrico na membrana seja constante. Além disso, $[X]_{\text {int }}$ e $[X]_{\text {out }}$ representam as concentrações do íon $X$ dentro (interno) e fora (externo) da célula. $P_{X}$ representa a permeabilidade da membrana ao íon $X$, em $\frac{\mathrm{cm}}{\mathrm{s}}$.

Tendo apenas as permeabilidades dos íons e suas concentrações, pode-se calcular, com a equação (2.11), a tensão de repouso da membrana. Por exemplo, considerando os seguintes valores (referentes à lula) é possível obter a tabela (2.1), retirada de Sterratt et al. (2011).

Tabela 2.1: Concentrações iônicas dentro e fora do meio celular, para os íons de potássio, sódio e cloro.

\begin{tabular}{|c|c|c|c|}
\hline Íon & $\mathrm{K}^{+}$ & $\mathrm{Na}^{+}$ & $\mathrm{Cl}^{-}$ \\
\hline \hline Concentração interna (mM) & 400 & 50 & 40 \\
\hline Concentração externa (mM) & 20 & 440 & 560 \\
\hline Potencial de equilíbrio (mV) & -72 & 52 & -64 \\
\hline
\end{tabular}

Fonte: Sterratt et al. (2011). 
Considerando ainda que as permeabilidades relativas do $\mathrm{K}^{+}, \mathrm{Na}^{+}$e $\mathrm{Cl}^{-}$são de 1,0, 0,03 e 0,1 (também vindo de Sterratt et al. (2011)), a tensão de equilíbrio obtida pela fórmula (2.11) é de aproximadamente $-60,0 \mathrm{mV}$, na temperatura de $6,3^{\circ} \mathrm{C}$.

Esses modelos matemáticos estão entre os primeiros modelos aplicados na neurociência. Eles representam uma base inicial de conhecimento fundamental para qualquer neurocientista, especialmente na área teórica. Além disso, esses modelos se tornaram uma espécie de referencial padrão, sendo comparado com muitas outras abordagens.

\subsection{Descrição de um canal iônico}

Os canais iônicos podem ser encarados como poros na membrana de uma célula (HILLE, 2001). Quimicamente, os canais são formados por proteínas, que se encaixam na membrana permitindo o fluxo de substâncias (normalmente íons ou pequenas moléculas hidrofílicas) de um lado para o outro ${ }^{11}$.

Um canal iônico possui duas características essenciais para o seu funcionamento: uma elevada seletividade, ou seja, cada canal permite a passagem de uma substância específica, mas não permite a passagem de outras (ou, caso isso ocorra, a permeabilidade é bastante inferior para outros tipos de íons (KEW; DAVIES, 2010; STERRATT et al., 2011; BEAR et al., 2007)). Para a substancia que o canal tem máxima seletividade, a taxa de difusão é muito elevada, próximo do que seria possível com uma membrana permeável à substância ou ao íon em questão.

Outra característica que diferencia os canais iônicos de outros meios de comunicação entre o interior e o exterior da célula é que os canais funcionam sem a necessidade de consumo de ATP (STERRATT et al., 2011; HILLE, 2001) (ou seja, eles atuam aproveitando a energia potencial acumulada nos gradientes de concentração ou diferença de potencial elétrico). O fluxo de íons ocorre essencialmente de acordo com duas forças: a difusão e a atração elétrica. Dessa forma, os canais não precisam de energia para o seu funcionamento, uma vez que o fluxo dos íons ocorre de forma natural, no sentido do restabelecimento do equilíbrio ${ }^{12}$.

Além dessas características, a maioria dos canais iônicos possui meios de abertura e fechamento, mediante condições específicas. Contudo, deve-se ressaltar que isso não

11 Alguns canais podem impor um sentido preferencial de íons, enquanto outros permitem a passagem em ambos os sentidos.

12 Por outro lado, o estabelecimento do gradiente de concentração dos íons precisa de energia, e é essencialmente feito pelas bombas. Dessa forma, o gradiente de concentração poderia ser considerada uma forma de acumulação de energia potencial, que depois é aproveitada pelos canais. 
ocorre sempre, e muitos canais podem ficar constantemente no estado aberto ou fechado. Por exemplo, nas membranas dos neurônios, alguns canais de potássio ficam constantemente abertos, dando origem a uma pequena corrente elétrica chamada de corrente de vazamento (ou leak current) presente nessas células (ALBERTS et al., 2008). Esses canais permanecem sempre no estado aberto e afetam a tensão de repouso da membrana celular (ALBERTS et al., 2008).

Um outro tipo de canal (também chamado de poro) presente nas membranas são as chamadas aquaporinas. Diferentemente dos canais iônicos, que permitem a passagem de íons como o cálcio, sódio ou potássio, as aquaporinas permitem apenas a passagem de água. Isso é fundamental para que as células possam controlar a quantidade interna de água bem como o seu volume (ALBERTS et al., 2008). Apenas como uma nota histórica, vale lembrar que o Prêmio Nobel de química de 2003 foi dado simultaneamente a P. Agre (pela descoberta das aquaporinas) e R. Mackinnon (pelos seus trabalhos com os canais de potássio). Dessa forma, é possível perceber como as aquaporinas e os canais iônicos estão relacionados.

Ainda que os canais estejam presentes em várias células do corpo humano, excitáveis ou não (HILLE, 2001; ALBERTS et al., 2008), nos neurônios os canais desempenham um aspecto absolutamente fundamental, trabalhando não só na geração e propagação do potencial de ação, mas também permitindo o funcionamento das sinapses. A grande variedade de tipos de canais iônicos gera uma grande variedade de comportamentos da tensão das membranas, o que por sua vez gera diferentes tipos de funcionamento celular e variações nas suas características essenciais, como a excitabilidade. Para entender o funcionamento dos neurônios, é fundamental entender o funcionamento dos canais e da sua membrana.

Problemas com os canais iônicos também estão na origem de diversas doenças do sistema nervoso, chamadas de canalopatias (BEAR et al., 2007). Alguns tipos de epilepsia têm sua origem no mal funcionamento dos canais iônicos em alguns tipos de neurônios (MULLEY et al., 2003; GEORGE, 2004; NOEBELS et al., 2012).

Os canais iônicos trabalham em conjunto com as bombas, porém de forma muito diferente. Ambos trabalham com o transporte de íons através da membrana, mas as bombas necessitam de alguma forma de energia para o seu funcionamento. Isso explica o porquê do fluxo do íons através das bombas ser várias ordens de magnitude inferior ao fluxo dos canais: o funcionamento das bombas requer energia. Já os canais, por não necessitarem do consumo direto energia, tendem a ser mais rápidos. Por outro lado, é preciso haver um gradiente de concentração preestabelecido para que os íons atravessem os canais. Esse 
gradiente é construído essencialmente pelo contínuo trabalho das bombas, que fazem com que os íons se acumulem contra o sentido energeticamente mais favorável (BEAR et al., 2007; KANDEL et al., 2012; ALBERTS et al., 2008).

Dessa forma, pode-se sumarizar o funcionamento dos canais e das bombas como um comportamento complementar: enquanto os canais, devido ao seu funcionamento rápido, permitem que a membrana sofra uma rápida alteração de tensão, as bombas lentamente tentam restabelecer a situação inicial de repouso da célula, acumulando energia potencial e permitindo que novas alterações de tensão ocorram no futuro. Temporariamente, um neurônio pode funcionar sem suas bombas, desde que a sua condição inicial possua as diferenças adequadas na concentração de íons dentro e fora da célula. Porém, conforme um neurônio interage com outras células ao seu redor (especialmente outros neurônios) e com o meio, se dá a abertura dos canais. Quando os canais se abrem, ocorre a troca de íons entre o interior e o exterior do neurônio, de forma que as diferenças de concentração iônicas inicialmente estabelecidas vão sendo lentamente alteradas, e sem o contínuo funcionamento das bombas reestabelecendo as concentrações iniciais, o meio interno e o meio externo dos neurônios entram em uma situação de equilíbrio, fazendo assim com que o neurônio não seja mais capaz de funcionar e disparar o potencial de ação (ALBERTS et al., 2008; BEAR et al., 2007).

Pode-se concluir que, para a elaboração de um modelo computacional de neurônio que fosse válido apenas por um breve período de tempo, não é necessário a inclusão das bombas. Porém, se no modelo se consideram efeitos de médio e longo prazo na concentração dos íons, é necessário incluir algum elemento que tenha o papel de restabelecer as concentrações iônicas iniciais, trabalhando como as bombas.

\subsubsection{Tipos de canais iônicos}

Células possuem uma grande diversidade de canais iônicos, cada tipo com características específicas. Contudo, é possível agrupar os canais iônicos de acordo com o tipo de estímulo que muda o seu estado, de fechado para aberto. Alguns canais são sensíveis à tensão da membrana, os chamados canais chaveados por tensão ${ }^{13}$. Outros podem ser chaveados por estímulos mecânicos, como os canais chaveados mecanicamente. Alguns são sensíveis a substâncias químicas, ou canais chaveados por substâncias químicas. Nesse último caso, a substância pode ser um neurotransmissor, um íon ou ainda um nucleotídio (ALBERTS et al., 2008).

\footnotetext{
${ }^{13}$ Aqui traduziu-se o termo gated como chaveado, algo comum em engenharia elétrica. O nome em inglês
} é voltage gated channels, e poderia ser traduzido, alternativamente como canais ativados por tensão. 
Os canais iônicos possuem uma elevada seletividade, e ao mesmo tempo permitem a rápida passagem de íons, o que pode parecer contraditório. Contudo, pesquisas recentes mostram que a seletividade dos canais iônicos vem não apenas do diâmetro dos íons que passam pelos canais, mas da forma como cada íon se comporta quando hidratado. Quando íons estão diluídos (na água), cada um fica rodeado por moléculas de $\mathrm{H}_{2} \mathrm{O}$, o que é chamado de hidratação. Essa camada de moléculas que se forma ao redor do íon tem características diferentes para cada tipo de íon; por exemplo, a camada de hidratação do sódio é diferente da camada de hidratação do potássio. Cada canal iônico reproduz um tipo específico de camada, dando ao íon um caminho de mínima energia para a sua passagem. Contudo, essa minimização é particular a um dado tipo de íon (de acordo com a forma da camada de hidratação). Assim, o canal é capaz de selecionar um íon baseado principalmente no formato da camada de hidratação (PLOPPER et al., 2013; DEGRÈVE et al., 1996). Como consequência, a atuação dos canais é passiva e depende apenas da diferença de concentração dos íons, e a velocidade de difusão não é severamente limitada, como nos casos das bombas iônicas (MACKINNON, 2003; ALBERTS et al., 2008). Dessa forma, obtém-se elevada seletividade com uma elevada taxa de difusão.

De acordo com Kandel et al. (2012), as três principais características dos canais iônicos são:

1. Reconhecer e selecionar íons.

2. Abrir e fechar de acordo com algum tipo de estímulo (elétrico, químico ou mecânico).

3. Conduzir o íon selecionado através da membrana (para dentro ou para fora da célula).

Um aspecto essencial de um canal iônico é a forma como ele reproduz a hidratação de um dado íon. Como diferentes íons possuem diferentes hidratações, o canal é transparente apenas para um tipo específico de íon. Quando íons com com diferentes cascas de hidratação entram no canal, eles encontram uma barreira de potencial, devido á interação com os resíduos das moléculas que formam a estrutura (parede) do canal. A membrana em si é impermeável aos íons; são os canais que formam um caminho entre o interior e o exterior da célula.

\subsubsection{A anatomia de um canal iônico: $O$ canal de potássio}

O canal de potássio tem um papel importante no estudo dos canais iônicos, devido ao fato desse canal possuir uma assinatura genética conhecida (correspondente ao filtro 
seletivo para o potássio) (HEGINBOTHAM et al., 1994). Deve-se observar também que o filtro não é apenas baseado no diâmetro do íon, uma vez que o íon de sódio possui um diâmetro de $0,96 \AA ̊$, enquanto o potássio tem um diâmetro de 1,33Å. Logo, se a seletividade do canal fosse baseada apenas no diâmetro, o canal de potássio, por ser maior que o de sódio, deveria permitir a passagem de ambos os íons. Contudo, isso não é observado ${ }^{14}$. É a hidratação dos íons que permite ao canal ser seletivo (ZHENG; TRUDEAU, 2015).

Os íons de potássio devem formar uma espécie de "fila", e também devem perder sua hidratação para entrar no canal. Ao interagir com resíduos das moléculas que formam a cavidade interna do canal, os íons conseguem passar sem necessitar das moléculas de água que normalmente o acompanham. Essa interação entre os íons e as moléculas de água ao seu redor formam a base do processo de seleção: diferentes íons interagem de forma diversa com as moléculas de água, e o formato da cavidade interna do canal iônico tenta reproduzir o perfil de hidratação dos íons na água. O canal que possui um perfil mais similar ao perfil de hidratação de um determinado íon tende a oferecer uma barreira de potencial menor. Para outros íons, com diferentes perfis de hidratação, a barreira é maior ${ }^{15}$ (ZHENG; TRUDEAU, 2015).

A "fila de íons" de potássio é fundamental para o funcionamento normal do canal. Se a densidade de íons de potássio se torna muito baixa, e apenas um íon se encontra na parte interna do canal, esse sofre uma mudança no seu formato, mudando seu estado. Dessa forma, a existência de uma fila de íons é necessária para a estabilização do canal em sua posição aberta (ZHOU; MACKINNON, 2003). Curiosamente, isso foi previamente previsto por Hodgkin e Keynes (1955). Supõe-se (ZHOU; MACKINNON, 2003) que a fila mantém o balanço de cargas estável do sistema composto pelo canal mais os íons de potássio.

Essa é apenas uma breve descrição do grau de complexidade que um único canal iônico pode ter. Obviamente, seria possível aprofundar ainda mais o estudo dos canais, com o intuito de se obter modelos de canais iônicos extremamente sofisticados. Contudo, isso tornaria mais difícil a obtenção de um modelo completo de neurônio que fosse viável, tanto do ponto de vista computacional quanto do ponto de vista de complexidade na modelagem (ou seja, temos aí o problema da parcimônia). Um modelo com um número excessivo de detalhes costuma ser de difícil entendimento. No trabalho atual, buscou-se obter um modelo computacional que seja simples de ser simulado e simples de ser compreendido, porém, sem se tornar trivial.

14 Existe um pequeno vazamento de íons de sódio, mas isso ocorre em uma taxa várias vezes menor que para o íon principal.

15 No site http://www.proteopedia.org/wiki/index.php/Potassium_channel é possível visualizar um modelo tridimensional do canal de potássio, que pode ser rotacionado no próprio navegador. 
O modelo proposto possui um número limitado de estados (dois ou três, dependendo do tipo de canal), sendo que cada estado também contém uma memória (do intervalo de tempo em que o canal se encontra em um determinado estado). Além disso, o modelo é essencialmente determinista. Dessa forma, ainda que o modelo de canal seja bem mais simples que um modelo quântico sofisticado (VAZIRI; PLENIO, 2010; KAUFMAN et al., 2015), deve-se ter em mente que o objetivo do presente trabalho é obter um modelo de neurônio baseado no comportamento dos canais iônicos.

\subsection{O neurônio}

The brain immediately confronts us with its great complexity. The human brain weighs only three to four pounds but contains about 100 billion neurons. Although that extraordinary number is of the same order of magnitude as the number of stars in the Milky Way, it cannot account for the complexity of the brain. The liver probably contains 100 million cells, but 1000 livers do not add up to a rich inner life.

Gerald D. Fischbach

Subindo um nível na hierarquia de complexidade proposta no primeiro capítulo, analisase agora o funcionamento do neurônio. O neurônio é uma célula excitável, que pode ser didaticamente dividida em três partes: corpo celular, axônios e dendritos. Essas três partes são distintas e identificáveis, e possuem um elevado grau de especialização. Grosso modo, pode-se dizer que os dendritos funcionam como uma espécie de "entrada" do neurônio (lembrando que existem muitas exceções para essa regra), recebendo sinais de outras células (especialmente de outros neurônios). Posteriormente, o corpo celular do neurônio (onde se localiza o núcleo da célula) é o local para onde todos os dendritos convergem, sendo uma espécie de "integrador" da informação recebida pelos dendritos. Saindo do corpo celular, tem-se o axônio, que pode ser visto como uma espécie de "cabo", sendo capaz de gerar e conduzir o potencial de ação por longas distâncias, sem perda de informação (contudo, isso requer o consumo de energia). Neurônios podem transmitir e processar 
essas informações. A principal forma de transmissão de informações entre neurônios é feita por meio das sinapses.

Figura 2.2: Diagrama simplificado de um neurônio e suas principais partes.

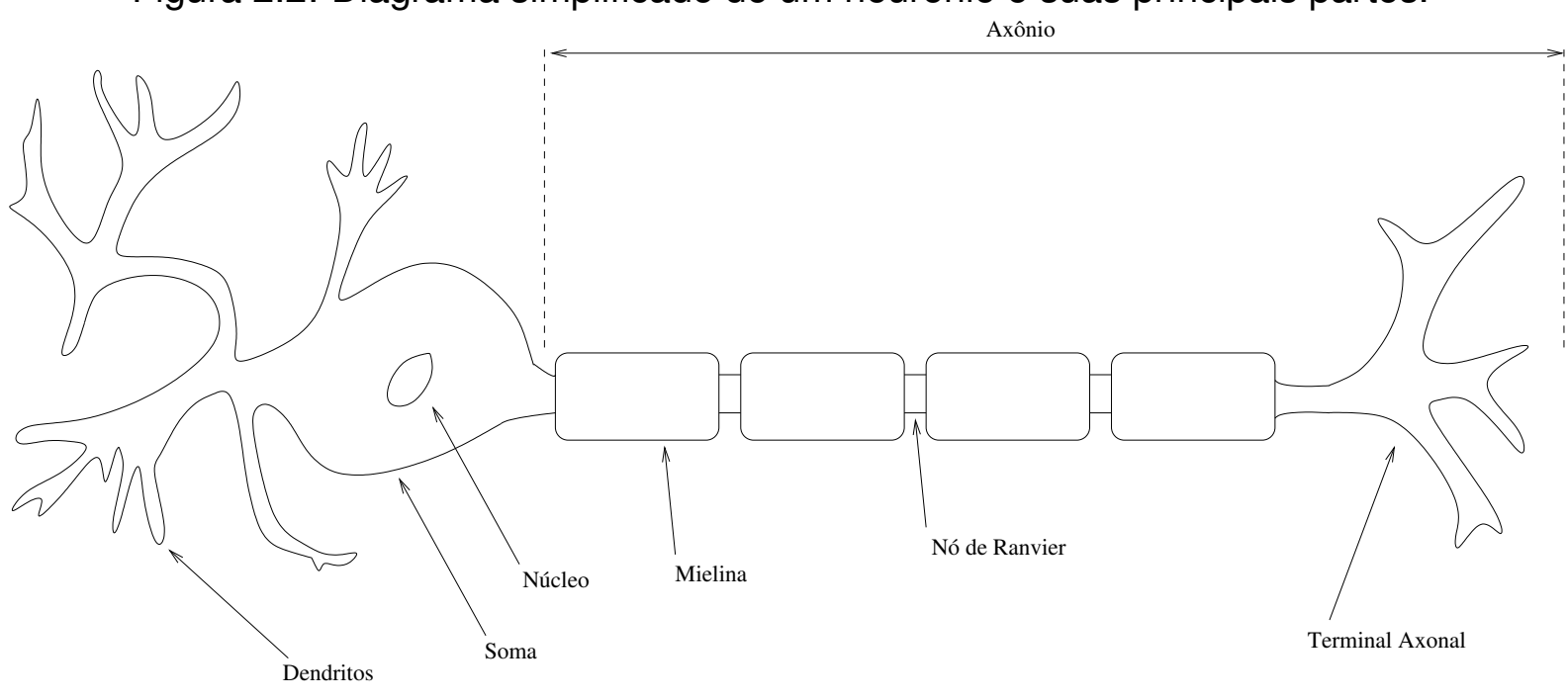

Fonte: Autor.

Na figura (2.2), mostra-se um diagrama simplificado de um neurônio. Deve-se observar que esse neurônio esquematizado é baseado em um neurônio típico do sistema nervoso de um organismo sofisticado, por exemplo, um mamífero. Nesse desenho também é mostrada a presença da mielina. A mielina está presente em uma célula separada que se fixa ao redor do neurônio, formando uma espécie de capa protetora. Essas células são chamadas de células de Schwann quando ocorrem no sistema nervoso periférico e de oligodendrócitos quando ocorrem no sistema nervoso central, provendo isolamento elétrico para o axônio, e também aumentando a velocidade e a distância de propagação. Nem todos os organismos possuem mielina em seus sistemas nervosos. Por exemplo, no neurônio da lula o potencial de ação tem uma elevada velocidade de propagação devido ao diâmetro grande desta célula, sendo praticamente visível a olho nu, e não possuem mielinização (a velocidade de propagação já é naturalmente elevada devido ao seu grande diâmetro, da ordem de $1 \mathrm{~mm}$ ). Todavia, se organismos como os seres humanos tivessem que utilizar a mesma abordagem (aumento do diâmetro para aumentar a velocidade de propagação), nosso cérebro seria do tamanho de uma sala de aula (BEAR et al., 2007). A mielina permite $o$ aumento da velocidade de propagação em um ambiente com dimensões restritas.

A visão apresentada do neurônio é bastante conveniente e simplificada, mas infelizmente omite uma realidade da neurociência: existem tantas exceções à regra que é difícil 
sequer estabelecer uma regra. Por exemplo, pode-se dizer que normalmente os dendritos funcionam como entradas e os axônios como saídas, porém existem várias situações em que existem conexões apenas entre axônios (no tálamo, por exemplo), ou apenas entre dendritos (BRADY et al., 2005). Além disso, o corpo celular do neurônio também recebe muitas sinapses inibitórias, mostrando a dificuldade do estabelecimento de regras gerais na neurociência.

A geometria dos neurônios também é bastante diversa, estando profundamente ligada ao seu papel na rede em que ele está inserido. E mesmo algumas partes, como o axônio, também podem ter subpartes. Por exemplo, é possível dividir o axônio em três partes: uma região inicial responsável pelo disparo do potencial de ação e uma etapa intermediária de condução, potencialmente para longas distâncias. No final do axônio tem-se a região présináptica, onde ocorre o contato com outro neurônio. Nessa parte, a membrana celular também sofre diversas modificações, para facilitar a comunicação com outros neurônios. Dessa forma, diversos fatores alteram a geometria e a estrutura de membrana celular de um neurônio. Adicionalmente, a diversidade de neurônios está ligada a variedade de tecidos ao qual eles se conectam, e também com a sua funcionalidade, como por exemplo (KANDEL et al., 2012; BEAR et al., 2007):

- A entrada de informações, como nos neurônio sensoriais;

- A saída de informações, como nos neurônios motores ou nas células neuroendócrinas;

- O processamento ou transmissão de informações, como nos interneurônios locais e os de projeção.

Além da classificação com relação ao papel do neurônio no organismo, é possível classificá-los de acordo com a sua estrutura geométrica. Nesse caso, o número de processos que saem do corpo celular, bem como a direção geral desses processos podem funcionar como uma forma de classificação adicional (KANDEL et al., 2012).

De um ponto de vista funcional, pode-se dizer que os neurônios constituem uma espécie de unidade computacional (BRUNEL et al., 2014), sendo que o poder computacional vem em grande parte da sua capacidade de interligação com outros neurônios, formando uma rede. Isso faz sentido, especialmente quando se pensa do ponto de vista evolutivo, uma vez que existe a necessidade dos organismos produzirem respostas rápidas e coerentes em um ambiente complexo e frequentemente perigoso, e ao mesmo tempo tendo limitações energéticas (NIVEN; LAUGHLIN, 2008). 
Figura 2.3: Diagrama simplificado de uma sinapse.

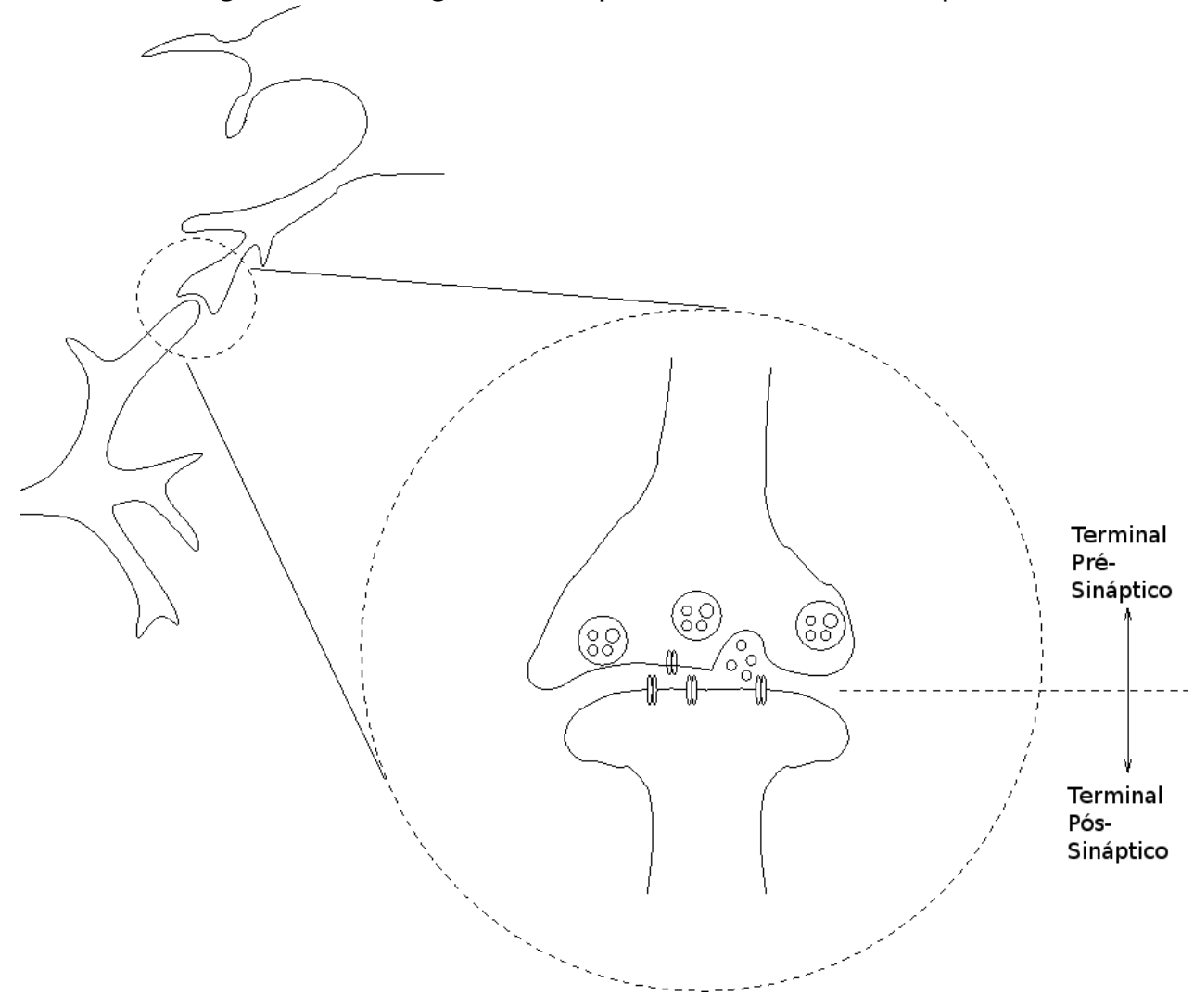

Fonte: Autor. 
As conexões entre neurônios, chamadas de sinapses, também podem ser divididas em dois tipos, elétricas e químicas. Na figura (2.3), mostra-se um diagrama simplificado de uma sinapse química típica.

\subsubsection{Aspectos evolutivos dos neurônios}

Um estudo de Sakarya et al. (2007) mostrou uma particularidade sobre as proteínas que compõem as sinapses: elas são bastante conservadas entre diversos organismos, inclusive entre aqueles que não possuem neurônios. Especula-se que essas proteínas podem ter sido parte de algum sistema primitivo de comunicação entre células (em algum organismo primitivo), ou talvez de algum órgão sensorial primordial. Curiosamente, substâncias como a serotonina podem ser encontradas em organismos como plantas (KANG et al., 2007), e receptores acoplados à proteína $G$ podem ser encontrados mesmo em organismos unicelulares (ROTH, 2008). Dessa forma, é possível perceber como soluções do passado podem ser reutilizadas de forma nova no futuro.

Baseado nesses estudos, pode-se fazer uma série de perguntas: qual é a origem evolutiva dos neurônios? Existe um protoneurônio? Qual seria o primeiro organismo a possuir uma rede neural? Qual seria o primeiro organismo a possuir um neurônio? Até o momento da redação do presente texto, não existe uma resposta definitiva para todas essas questões, porém, um conjunto de teorias procura elucidar, ao menos em parte, muitas delas.

Essencialmente, existem duas grandes abordagens para a origem dos neurônios: monofilética (HIRTH; REICHERT, 2007) e polifilética (MOROZ, 2009). No caso monofilético, supõe-se que um ancestral comum a todos os organismos (que atualmente possuem neurônios) possuía um sistema nervoso primitivo (ou algo parecido) e que todos os sistemas nervosos evoluíram a partir desse sistema nervoso primordial (HIRTH; REICHERT, 2007). Por outro lado, no caso polifilético, o sistema nervoso teria surgido diversas vezes em diferentes grupos, com características similares devido ao tipo de pressão evolutiva que esses organismos sofreram ao longo de sua trajetória (MOROZ, 2009; MOROZ et al., 2014). Além disso, não existiria um único neurônio precursor, mas sim um grupo de células similares, que, ao longo de diversos processos convergentes deram origem a sistemas nervosos complexos e similares.

O problema de responder a essa questão vem da dificuldade em se encontrar fósseis de organismos primitivos que permitam a análise da presença (ou não) do sistema nervoso. Não se pode dizer que a simples ausência de evidência seja uma evidência da ausência.

Dessa forma, a pesquisa sobre a evolução dos neurônios deve ter como foco as respostas à duas perguntas fundamentais: 
1. O que é um neurônio?

2. Por que um neurônio é o que ele é?

Entender o processo evolutivo do sistema nervoso depende de um critério claro para a sua identificação, o que pode nos auxiliar a entender a sua forma e função atuais. Essas questões são fundamentais para a Ciência em geral e para a neurociência em particular.

Em algumas pesquisas, as similaridades entre os sistemas nervosos do clado Bilateria apontam para uma origem comum (HIRTH; REICHERT, 2007):

The available data suggest that only one ancestral, albeit rather complex, nervous system was at the origin of bilateral $\mathrm{CNS}^{16}$ evolution (HIRTH; REICHERT, 2007).

Por outro lado, em outros estudos, as diferenças são mais relevantes que as similaridades (MOROZ, 2009):

The observed diversity of bilaterian nervous systems (especially from less investigated groups such as brachiopods, phoronids, echiurids, priapulids, hemichordates, echinoderms including crinoids, Xenoturbella, etc.) and recent reconstructions of the animal phylogeny can challenge this view of a monophyletic origin of bilaterian CNS from an ancestral centralized nervous system in the Urbilateria (MOROZ, 2009).

Um artigo publicado na revista Nature por Moroz et al. (2014) apresenta argumentos para hipótese do surgimento independente do sistema nervoso dos ctenóforos.

O objetivo do presente trabalho não é resolver nem explorar o problema da origem dos neurônios, mas de criar um modelo de neurônio que seja simples, porém (razoavelmente) realista. Contudo, para alcançar esse objetivo, é preciso saber quais seriam as características essenciais mais significativas de um neurônio. Esse mesmo tipo de questionamento surge na busca em se reconhecer qual é o (potencial) protoneurônio e quais são as características que podem ser atribuídas a esse protoneurônio, como visto em (MOROZ, 2009):

1. Neurônios são células assimétricas ${ }^{17}$, altamente polarizáveis, secretoras, com múltiplos compartimentos especialistas (adaptado de Moroz (2009)).

16 CNS quer dizer central neuron system, ou sistema nervoso central.

17 Por assimetria se entende não apenas sua morfologia, mas também que partes diferentes do neurônio possuem funções diferentes. 
2. Neurônios devem ser capazes de se conectar a outros neurônios (sinapses) ou a outros tecidos (por exemplo, a junção neuromuscular). Observa-se, contudo, que nem todos os organismos com neurônios formam essas conexões (em alguns organismos primitivos, algumas células excitáveis similares aos neurônios possuem uma capacidade de resposta individual, não se comunicando de nenhuma forma óbvia com o restante do organismo). Alguns organismos podem possuir outra forma de comunicação, utilizando substâncias similares aos hormônios (adaptado de Moroz (2009)).

3. Neurônios normalmente expressam uma quantidade significativa dos genes de um organismo. Essa característica possui uma grande vantagem: ela pode ser medida de forma objetiva (adaptado de Moroz (2009)).

Do ponto de vista do desenvolvimento de um organismo em particular (por exemplo, no caso de um mamífero), sabe-se claramente de onde os neurônios se originam. Nos humanos, os neurônios se originam da ectoderme, ou seja, da camada mais externa do embrião (KANDEL et al., 2012). Adicionalmente, sabe-se que as células da ectoderme que não vão formar órgãos do sistema nervoso irão dar origem à pele (KANDEL et al., 2012).

Dessa forma, a questão não é simplesmente identificar neurônios em humanos ou cachorros, mas sim identificar quando, na escala evolutiva, surgiu a especialização que deu origem aos neurônios.

Dado que diversos genes e substâncias associadas ao funcionamento dos neurônios podem ser encontradas em organismos que não possuem neurônios (e algumas vezes são unicelulares), pode-se pensar que muitos dos "ingredientes" para a construção dos neurônios (e mesmo das redes neurais) já se encontravam à disposição em células primitivas.

Uma outra possível abordagem para a investigação desse problema consiste em se encarar o neurônio como um fenômeno emergente (ou um epifenômeno) de elementos básicos que já existiam. Entre esses elementos, os canais e algumas substâncias (como por exemplo os neurotransmissores) formam os principais ingredientes. O neurônio, atuando como um sensor ou de forma computacional, é, portanto, uma combinação desses elementos. Assim, uma forma de criar um modelo de neurônio é justamente se basear nesses mesmos elementos fundamentais, essencialmente uma estratégia botton-up, ao invés das diversas abordagens top-down, em que o neurônio é modelado a partir de equações que descrevem o seu comportamento global.

A busca de uma explicação para a origem evolutiva dos neurônios deve ser cautelosa com relação a ideia de "soluções ótimas". Organismos biológicos reais não precisam ne- 
cessariamente obter a melhor resposta possível, mas uma resposta que seja a melhor do ponto de vista competitivo, ou seja, uma resposta "boa o bastante" para garantir a sobrevivência e a reprodução (o artigo de Loeb (2012) desenvolve melhor essa ideia, contudo, pode-se confrontar essa posição com o artigo de Niven e Laughlin (2008), que sugere fortemente a existência de um processo de otimização). As implicações dessa visão são muito importantes para a elaboração de um modelo que vise não apenas explicar o funcionamento de uma determinada característica biológica (por exemplo, a formação das redes neurais e o seu desempenho), mas essencialmente explicar também como essa rede surgiu.

\subsection{0 potencial de ação}

O potencial de ação pode ser visto como um pulso, um sinal estereotipado de transmissão. Essa é uma ideia bastante comum na área de engenharia elétrica: ondas quadradas são um exemplo frequente, e sistemas digitais de telecomunicações estão repletos de pulsos estereotipados. Por outro lado, é incomum pensar em sistemas biológicos com características digitais. Ao menos à primeira vista, a ideia de um sistema análogo pode ser mais convincente ${ }^{18}$.

Contudo, ao menos com relação ao sistema nervoso, as pesquisas indicam que rapidamente os sistemas biológicos evoluíram na direção de técnicas digitais de codificação e transmissão de sinais. Ainda que as sinapses (que são discutidas mais adiante) sejam muito mais complexas que simples chaves do tipo aberto/fechado, o disparo do potencial de ação é um típico evento tudo ou nada (BEAR et al., 2007; KANDEL et al., 2012). Sua propagação ao longo do axônio mantém o seu formato de forma notável, mesmo em distâncias relativamente longas, com alguns neurônios podendo ter mais de um metro de comprimento (BEAR et al., 2007).

Na figura (2.4), pode-se observar o formato de um potencial de ação típico, obtido como resultado da simulação das equações de Hodgkin e Huxley (mais adiante esse modelo será detalhado). O formato gerado pelo modelo é bastante similar ao encontrado no neurônio da lula, e não é muito diferente, ao menos de forma geral, dos encontrados nos neurônios de outros animais. Ainda que as medidas do potencial de ação sejam de caráter puramente elétrico (essencialmente o que se mede é a magnitude da tensão ou corrente elétrica em uma região da membrana), fisicamente tem-se a interação de fenômenos químicos e elétricos. Dessa forma, pode-se afirmar que o potencial de ação é resultado de um

\footnotetext{
18 O termo comum é analógico, mas esse é na realidade um erro de tradução que se tornou lugar-comum.
} 
Figura 2.4: O potencial de ação. No eixo das ordenadas tem-se a tensão do trecho de membrana, em milivolts, e no eixo das abscissas tem-se o tempo, em milissegundos.

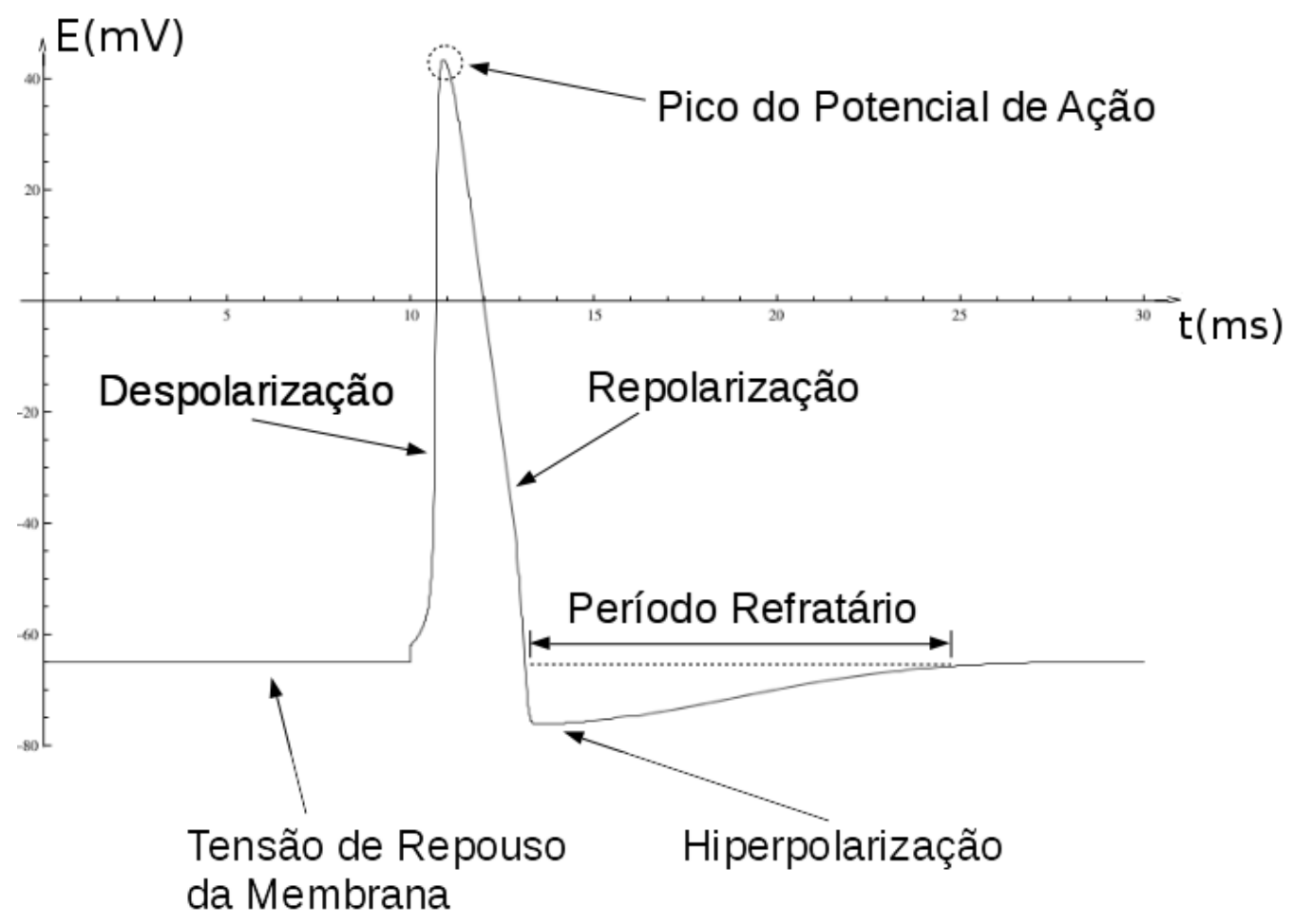

Fonte: Autor. 
processo físico-químico, ainda que as suas medidas e muitos de seus modelos sejam essencialmente elétricos.

Costuma-se dividir o potencial de ação em fases: inicialmente existe uma rápida despolarização da membrana, em função da abertura dos canais de sódio. O valor de tensão da membrana sobe, até atingir um valor de pico, de duração bastante breve, seguido pelo fechamento dos canais de sódio e da abertura dos canais de potássio, que revertem a situação, levando à repolarização da membrana, fazendo com que a tensão diminua. Esse processo leva à chamada hiperpolarização, em que os valores de tensão da membrana ficam inferiores ao valor de repouso, por um certo período de tempo. Esse período normalmente é chamado de período refratário (esse mesmo também pode ser dividido em duas partes, mas no momento esse aspecto não é relevante).

Evidentemente, essa descrição é uma simplificação, baseada no modelo original da lula de Hogkin e Huxley (HODGKIN; HUXLEY, 1952). Se a variedade de tipos de canais disponíveis na membrana for aumentada, pode-se ter uma série de mudanças no comportamento dinâmico do neurônio. Mesmo assim, esse modelo simplificado é bastante didático e útil, e é a principal explicação encontrada em livros introdutórios de neurociência.

Não se pode confundir o comportamento do potencial de ação que serve como um pulso de comunicação em "longas distâncias" com as mudanças dos valores de tensão causadas nas sinapses (químicas). Em um neurônio típico, o fim do axônio está conectado ao lado pré-sináptico, onde a membrana celular sofre novamente uma série de modificações estruturais, tendo agora outros tipos de canais. Além dos canais de sódio e potássio, existe um aumento no número de canais de cálcio (BEAR et al., 2007; STERRATT et al., 2011), entre outras mudanças. O cálcio tem um papel bastante diferente dos íons anteriores. Se o sódio e o potássio servem como agentes que carregam (ou descarregam) a membrana, o cálcio atua mais como um mensageiro: seu papel é disparar uma série de reações internas na célula, especialmente aquelas que levam à liberação de neurotransmissores. Dessa forma, nas sinapses, a mudança do potencial de membrana tem um papel diferente do encontrado no axônio, e nesse caso tem um caráter mais "analógico".

Os neurotransmissores, uma vez lançados na fenda sináptica (o pequeno espaço que separa as duas células), influenciam a célula seguinte, o terminal pós-sináptico, onde existem uma série de receptores. Esses receptores, uma vez abertos, podem afetar a tensão da membrana (observe que agora fala-se da membrana de outra célula, que recebe a informação). Essa influência depende do tipo do neurotransmissor, da quantidade de neurotransmissores liberada, dos receptores envolvidos e da sensibilidade desses receptores ao neurotransmissor em questão. Todos esses fatores vão essencialmente afetar a forma 
Figura 2.5: O agrupamento das vesículas sinápticas dentro do neurônio.

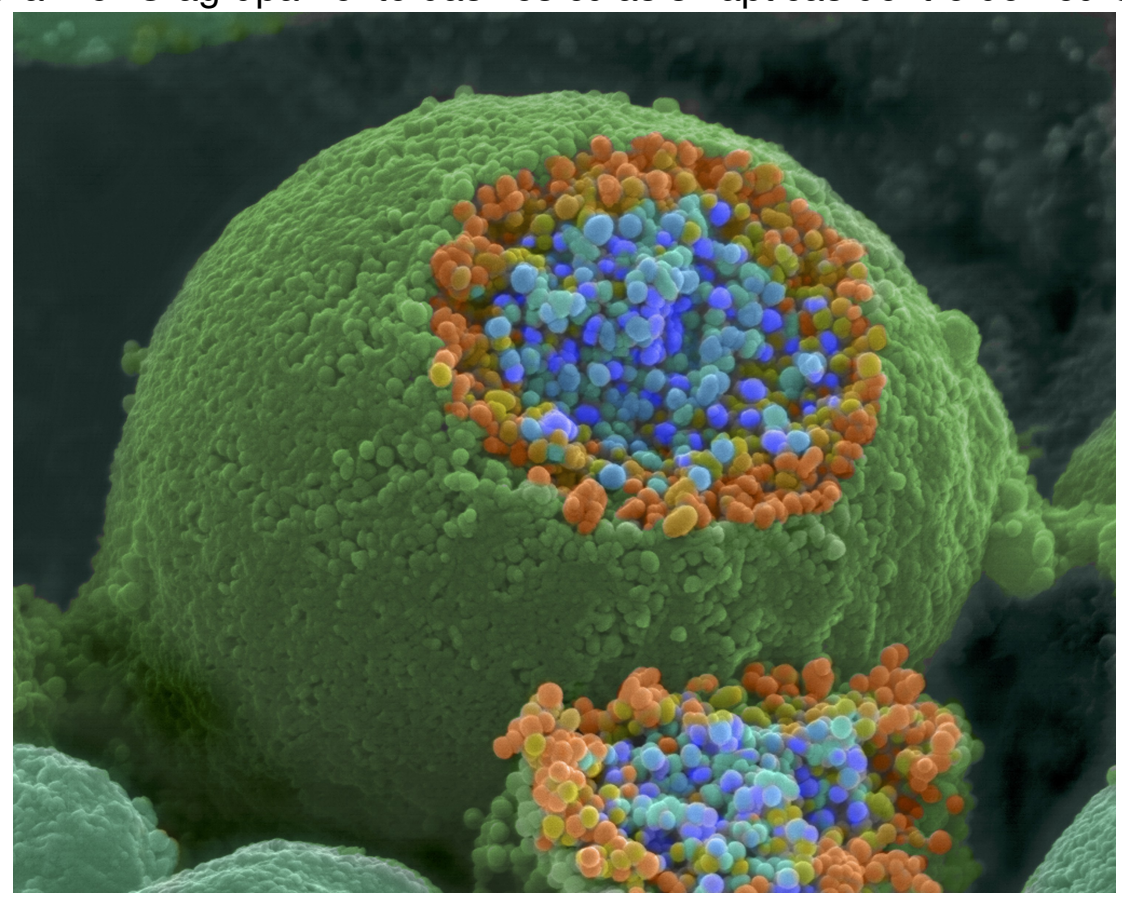

Fonte: Carvalho (2010).

como o potencial de membrana é gerado. Na figura (2.5), mostra-se uma foto obtida por um microscópio eletrônico de varredura (colorida artificialmente) que ilustra o final de um neurônio aberto, mostrando as vesículas sinápticas (em laranja e azul) dentro da membrana da célula (CARVALHO, 2010).

O neurônio receptor de uma conexão pode então disparar ou não. Caso ele dispare, esse disparo pode ocorrer de diversas formas: um único disparo, um disparo contínuo de potenciais de ação (como um trem de pulsos), ou pequenas rajadas de disparos, seguidas de um silêncio e novamente um conjunto de pulsos. O repertório de tipos de disparos é bastante elevado e normalmente é característico de um conjunto de células com funções específicas. A figura (2.6), retirada de Izhikevich (2003), ilustra alguns tipos de disparos apresentados por um modelo artificial de neurônio, porém com base em neurônios reais. 
Figura 2.6: Alguns tipos de disparo de um neurônio.
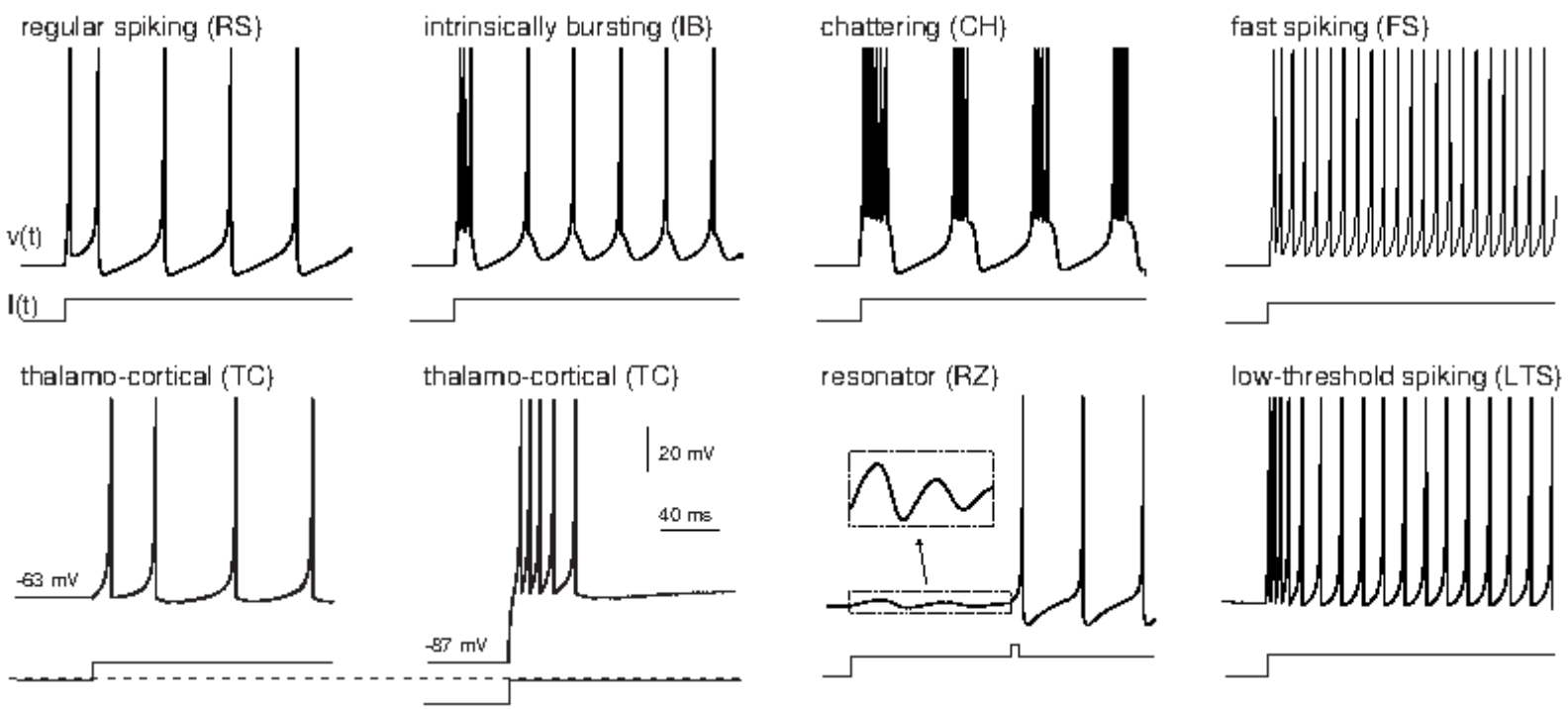

Fonte: adaptado de (IZHIKEVICH, 2003).

\subsection{Sinapses químicas e elétricas}

A neurociência já nasceu com um debate de gigantes, entre os cientistas C. Golgi e S. Ramón y Cajal. Esses cientistas trabalharam entre o final do século XIX e início do século XX, na então infância da neurociência. Ambos tiveram um papel essencial. Golgi desenvolveu uma técnica capaz de "corar" uma célula de um tecido biológico de forma seletiva, fazendo com que uma única célula se destacasse na multidão de células vizinhas. Dada a limitação dos microscópios da época e a complexidade dos tecidos, esse avanço foi fundamental. Sem isso, os tecidos apareciam de uma forma homogênea e sem características discerníveis no microscópio, sendo impossível um estudo detalhado (BEAR et al., 2007).

Seu "rival", Ramón y Cajal, aplicou exatamente as técnicas de Golgi para estudar os tecidos do cérebro. Com essas foi possível discernir as células do sistema nervoso central. O resultado foi tão brilhante que ambos ganharam o Prêmio Nobel de Medicina em 1906.

Mas ambos discordavam com relação ao funcionamento do sistema nervoso. Para Golgi, o sistema nervoso funcionava como um sistema contínuo, similar ao sistema vascular. Para Cajal, era o contrario: essa situação seria uma violação do postulado de que os organismos são compostos de células, e que as células são a unidade básica de organização. As células deveriam estar ligadas de "alguma forma", porém atuavam de forma separada, construindo uma rede com conexões. Hoje, costuma-se dizer que Cajal tinha razão, pois de fato, as sinapses químicas representam exatamente uma forma de comuni- 
cação entre células próximas e separadas, e também permitem que o potencial de ação se propague de uma célula para outra. Dessa forma, cada célula (neurônio) atua como uma unidade independente.

Contudo, mesmo a abordagem de Cajal levava a uma nova pergunta: como funciona a conexão entre os neurônios? Essa discussão era baseada em uma dicotomia: um grupo de cientistas achava que a conexão era de natureza elétrica, enquanto outro grupo achava que a conexão ocorria de forma química.

Em 1921, O. Loewi fez o seu famoso experimento descobrindo o Vagusstoff, o neurotransmissor que hoje é chamado de acetilcolina. Essa descoberta validou a hipótese de que as sinapses (as conexões entre os neurônios) ocorrem de forma química, e não elétrica. Loewi é considerado o pai da neurociência ${ }^{19}$.

Porém, experimentos posteriores apontavam para um outro tipo de conexão entre neurônios. Ao estudar o peixe-elétrico (entre outros organismos), M. Bennett e seus colegas foram capazes de identificar claramente conexões de natureza elétrica (BENNETT, 1985, 2000, 1997). Essas conexões, chamadas de sinapses elétricas, são na realidade formadas por pequenos poros que conectam fortemente duas células, criando uma espécie de "cano" em que íons e mesmo pequenas moléculas podem passar, conectando o citoplasma de duas células. Em inglês, essas sinapses são chamadas de gap junctions, e são formadas por proteínas chamadas de conexinas (LAIRD, 2006; NIELSEN et al., 2012). Além disso, pesquisas feitas posteriormente por outros grupos mostraram que as sinapses elétricas existem no sistema nervoso de vários animais, inclusive nos seres humanos, ainda que em números consideravelmente inferiores aos das sinapses químicas.

Portanto, existem ao menos dois tipos de sinapses no sistema nervoso: sinapses químicas e sinapses elétricas. Ambas são muito importantes para o funcionamento do sistema nervoso, mas cada uma tem um papel diferente. A sinapse química é mais numerosa e essencialmente adiciona uma capacidade de "processamento" (ABBOTT; REGEHR, 2004), sendo muito mais do que uma simples chave que liga duas células. A sinapse elétrica, por outro lado, atua diretamente integrando o citoplasma das células envolvidas. Como Bennett comentou: "Cajal escreveu que o sistema nervoso é formado de neurônios individuais, de forma descontínua. Mas ele também escreveu que a doutrina dos neurônios também pode resistir a certas exceções. A conexão direta entre o interior de várias células provida pelas junções comunicantes pode ser vista como uma exceção" (BEAR et al., 2007)20. De

\footnotetext{
19 A neurociência tem a estranha característica de ter vários pais, como Otto Loewi, Santiago Ramón y Cajal ou até mesmo Galeno na antiguidade.

20 A tradução foi feita pelo autor do presente trabalho.
} 
certa forma, pode-se dizer que restou para Golgi um "pequeno triunfo", ainda que Cajal tenha sido o grande "vencedor".

\title{
2.7 O sistema nervoso
}

\author{
You think that because you understand \\ one that you must therefore understand \\ two because one and one make two. \\ But you forget that you must also \\ understand and.
}

Pensamento Sufista, retirado de Meadows e Wright (2008)

Pode-se considerar o sistema nervoso como um órgão de processamento e controle. Seu objetivo é fornecer um ajuste de curto prazo, ou seja, alterar o comportamento de um organismo no curto prazo baseado em um modelo da sua situação atual. A genética provê um ajuste de longo prazo e o metabolismo químico (como por exemplo, os hormônios) fornece um ajuste intermediário, de médio prazo.

Nessa visão, pode-se dizer que há uma hierarquia de memórias. O genoma é a base, consistindo da memória mais permanente e que dura gerações. Nele são armazenados as estratégias de sobrevivência absolutamente fundamentais e necessárias para a existência do organismo (e da sua espécie).

O genoma constitui uma memória de longo prazo, mas os organismos vivos precisam lidar também com situações mais imediatas. O metabolismo químico pode ser visto como uma outra forma de memória, que pode durar poucos minutos ou toda uma vida. Assim, por exemplo, quando um organismo altera seu metabolismo de forma a se adaptar ao inverno, hibernando, o metabolismo funciona ao mesmo tempo como controle e memória: os ciclos do metabolismo constituem a memória de suas adaptações.

Mas os organismos precisam também de uma escala muito mais rápida de adaptação, da ordem de segundos (ou até menor), aliado a um controle preciso e rápido de diversas funções e movimentos. E nessas circunstâncias que o sistema nervoso possui um papel fundamental.

No próximo capítulo, apresentam-se diversos modelos de neurônios utilizados em neurociência. Além disso, discute-se como esses modelos inspiraram o desenvolvimento do presente trabalho. 


\title{
Capítulo 3
}

\section{Modelos em neurociência}

\author{
The sciences do not try to explain, they \\ hardly even try to interpret, they mainly \\ make models. By a model is meant a \\ mathematical construct which, with the \\ addition of certain verbal \\ interpretations, describes observed \\ phenomena. The justification of such a \\ mathematical construct is solely and \\ precisely that it is expected to work - \\ that is correctly to describe phenomena \\ from a reasonably wide area. \\ Furthermore, it must satisfy certain \\ esthetic criteria - that is, in relation to \\ how much it describes, it must be rather \\ simple.
}

John von Neumann

\subsection{Modelos matemáticos e computacionais em neuroci- ência}

A neurociência pode ter sido uma das primeiras ciências a se utilizar da computação, ainda na época em que o computador era um humano repetindo manualmente um algoritmo (HUXLEY, 2002). No quarto artigo da série que deu origem ao Prêmio Nobel de 1963 
de Medicina (HODGKIN; HUXLEY, 1952), há essencialmente a exposição de um modelo elétrico (e computacional) para a dinâmica da tensão elétrica da membrana da lula.

Figura 3.1: Modelo elétrico da membrana da lula.

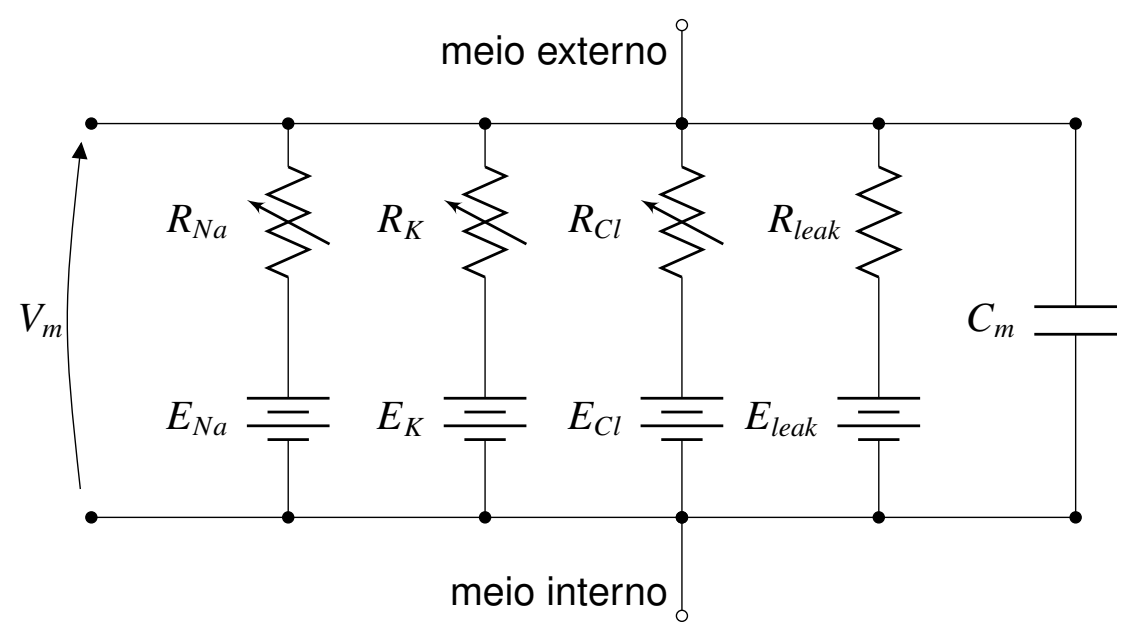

Fonte: Adaptado de Hodgkin e Huxley (1952).

$\mathrm{Na}$ figura (3.1), mostra-se a estrutura básica desse modelo, composta basicamente de três resistências variáveis, $R_{N a}, R_{K}$ e $R_{C l}$, que simulam os canais de sódio, potássio e cloro, que se alteram conforme a abertura ou o fechamento dos canais em um trecho de membrana. Uma quarta resistência $R_{\text {leak }}$ (fixa) modela a passagem de uma corrente conhecida como a corrente de vazamento, ou seja, uma corrente que continuamente "vaza" da célula, provavelmente devido a alguns tipos de canais de potássio que se mantêm continuamente abertos, independente da tensão da membrana. Supõe-se que esses canais continuamente abertos ajudem a manter o potencial de repouso da membrana próximo do valor do potencial de reversão do potássio (ALBERTS et al., 2008). Ainda na figura (3.1), as baterias $E_{N a}, E_{K}, E_{C l}$ e $E_{\text {leak }}$ representam os potencias de equilíbrio para os respectivos íons de sódio, potássio, cloro e para a corrente de vazamento.

Nesse modelo, o capacitor $C_{m}$ representa a capacitância da membrana celular. Devese lembrar que a membrana é praticamente impermeável a íons, funcionando como uma espécie de dielétrico. Além disso, a membrana celular possui uma espessura muito pequena, fazendo com que os íons de ambos os lados da membrana consigam interagir eletricamente. Dessa forma, íons de carga opostas tendem a se acumular de ambos os lados da membrana. Os íons que atravessam a membrana tendem a ficar acumulados ao seu redor, essencialmente "carregando um capacitor". Essa capacitância representa esse fenômeno, e é usualmente expressa na unidade $\frac{F}{\mathrm{~cm}^{2}}$. Esse modelo pode ser utilizado para o cálculo da tensão da membrana. 
Considerando apenas os canais de vazamento, de sódio e de potássio, bem como a presença de uma corrente axial (ou seja, uma corrente líquida entre os trechos vizinhos da membrana, e não apenas entre o interior e o exterior da célula), é possível obter uma equação diferencial que descreve a evolução temporal do potencial de membrana $E$ em função das correntes associadas aos canais iônicos (HODGKIN; HUXLEY, 1952; STERRATT et al., 2011):

$$
C_{m} \frac{\partial E}{\partial t}=-\bar{g}_{L}\left(E-E_{\text {leak }}\right)-\bar{g}_{N a} m^{3} h\left(E-E_{N a}\right)-\bar{g}_{K} n^{4}\left(E-E_{K}\right)+\frac{d}{4 R_{a}} \frac{\partial^{2} V}{\partial x^{2}}
$$

$\mathrm{Na}$ equação (3.1), $R_{a}$ corresponde à resistência axial do axônio, $d$ corresponde ao diâmetro do axônio em questão, e as variáveis $m, h$ e $n$ são as variáveis de chaveamento, que definem a evolução temporal das condutâncias. Os parâmetros $\bar{g}_{K}, \bar{g}_{N a}$ e $\bar{g}_{\text {leak }}$ correspondem aos valores máximos de condutância para cada uma das respectivas correntes. Observe a existência de derivadas parciais tanto no tempo quanto no espaço.

Para o sódio, as variáveis de chaveamento de ativação e inativação $m$ e $h$ evoluem de acordo com o seguinte conjunto de equações:

$$
\begin{array}{r}
\frac{d m}{d t}=\alpha_{m}(1-m)-\beta_{m} m \\
\alpha_{m}=0,1 \frac{E+40}{1-e^{-(E+40) / 10}} \\
\beta_{m}=4 e^{-(E+65) / 18} \\
\frac{d h}{d t}=\alpha_{h}(1-h)-\beta_{h} h \\
\alpha_{h}=0,07 e^{-(E+65) / 20} \\
\beta_{h}=\frac{1}{e^{-(E+35) / 10}+1}
\end{array}
$$

Para o potássio, a variável de ativação $n$ varia de acordo com:

$$
\begin{gathered}
\frac{d n}{d t}=\alpha_{n}(1-n)-\beta_{n} n \\
\alpha_{n}=0,01 \frac{E+55}{1-e^{-(E+55) / 10}} \\
\beta_{n}=0,125 e^{-(E+65) / 80}
\end{gathered}
$$


A simulação dessas equações (normalmente feitas em um computador digital, mas originalmente integradas manualmente com máquinas de calcular, por Hodgkin e Huxley) permite uma descrição precisa do potencial elétrico da lula. Contudo, essas equações são bastante complexas, e é bastante comum a simplificação em que a corrente elétrica axial é nula (ou seja, na condição de voltage-clamp) (STERRATT et al., 2011):

$$
C_{m} \frac{\partial E}{\partial t}=-\bar{g}_{L}\left(E-E_{\text {leak }}\right)-\bar{g}_{N a} m^{3} h\left(E-E_{N a}\right)-\bar{g}_{K} n^{4}\left(E-E_{K}\right)
$$

A partir do modelo original de Hodgkin e Huxley, é possível calcular a tensão de repouso de membrana, um cálculo ainda mais simples, uma vez que nesse estado as derivadas (temporais) são nulas.

Figura 3.2: Circuito elétrico equivalente a uma aproximação ôhmica da membrana celular de um neurônio.

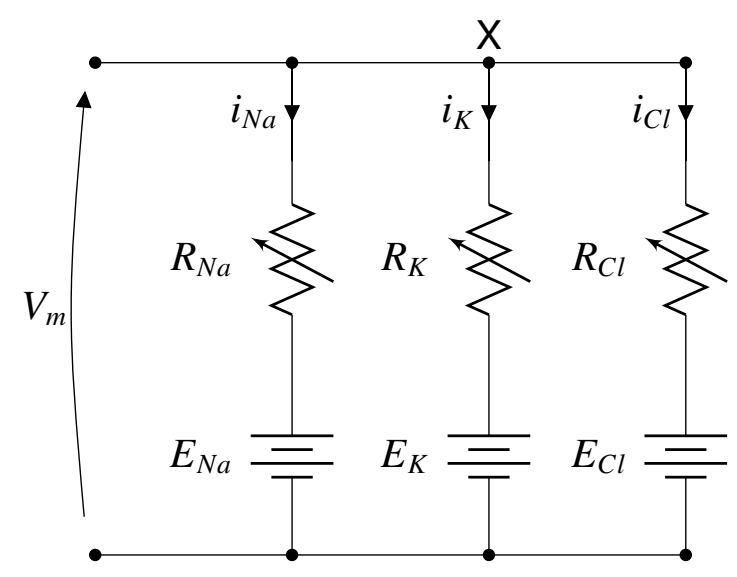

Fonte: Adaptado de Sterratt et al. (2011).

$\mathrm{Na}$ figura (3.2), apresenta-se essencialmente o mesmo modelo da figura (3.1), porém considerando uma condição de repouso (ou seja, em corrente contínua). Além disso, despreza-se $o$ efeito da corrente de vazamento. Ainda na mesma figura, $i_{N a}, i_{K}$ e $i_{C l}$ correspondem às correntes de sódio, potássio e cloro passando pela membrana (essas correntes correspondem ao somatório das correntes passando em todos os respectivos canais do trecho da membrana, e não a corrente de um único canal). Sabe-se que:

$$
i_{N a}+i_{K}+i_{C l}=0
$$


aplicando-se a lei de conservação de cargas no nó $X$ da figura (3.2). Fazendo $g_{N a}=\frac{1}{R_{N a}}$, $g_{K}=\frac{1}{R_{K}}$ e $g_{C l}=\frac{1}{R_{C l}}$ :

$$
\begin{array}{r}
V_{m}-E_{N a}=i_{N a} / g_{N a} \\
V_{m}-E_{K}=i_{K} / g_{K} \\
V_{m}-E_{C l}=i_{C l} / g_{C l}
\end{array}
$$

Isolando as correntes $i_{N a}, i_{C l}$ e $i_{K}$ nas equações (3.6a), (3.6b) e (3.6c), e substituindo na equação (3.5), obtém-se:

$$
g_{N a} E_{N a}+g_{K} E_{K}+g_{C l} E_{C l}=\left(g_{N a}+g_{C l}+g_{K}\right) V_{m}
$$

e finalmente isolando $V_{m}$, obtém-se:

$$
V_{m}=\frac{g_{N a} E_{N a}+g_{K} E_{K}+g_{C l} E_{C l}}{g_{N a}+g_{C l}+g_{K}}
$$

Considerando os seguintes valores, retirados de Kandel et al. (2012): $g_{N a}=0.510^{-6} S$, $g_{K}=1010^{-6} S, g_{C l}=2.510^{-6} S, E_{N a}=+55 m V, E_{K}=-75 m V$ e $E_{C l}=-69 m V$, obtém-se:

$$
V_{m}=\frac{g_{N a} E_{N a}+g_{K} E_{K}+g_{C l} E_{C l}}{g_{N a}+g_{C l}+g_{K}}=-68.85 m V
$$

Esse valor difere um pouco do valor obtido da equação de Nernst (no caso $-60 \mathrm{mV}$ ), mas ainda sim é um valor próximo do valor típico (que é por volta de $-65 \mathrm{mV}$ na temperatura de $\left.6.3^{\circ} \mathrm{C}\right)$.

\subsection{Neurônios e circuitos elétricos}

A teoria de circuitos elétricos tem uma utilidade surpreendente na área de neurociência. Livros como o de Gabbiani e Cox (2010) e o de Sterratt et al. (2011) ilustram a utilização de diversos circuitos elétricos para a construção de vários tipos de modelos. 
Figura 3.3: Circuito elétrico modelando uma sinapse inibitória.

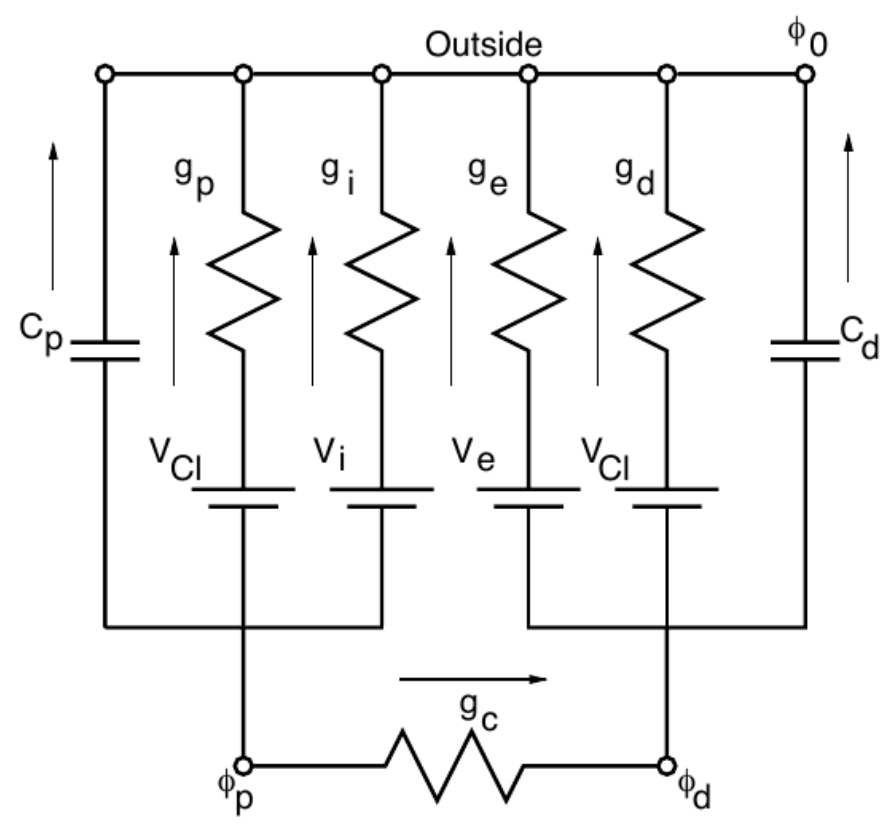

Fonte: Gabbiani e Cox (2010).

Na figura (3.3), mostra-se um exemplo de um modelo de sinapse inibitória (também chamada de sinapse inibitória proximal, uma vez que essa ocorre próxima ao corpo celular do neurônio), retirado de Gabbiani e Cox (2010). Nessa figura, $g_{p}$ e $c_{p}$ representam a condutância e a capacitância próxima ao corpo celular do neurônio, enquanto $g_{d}$ e $c_{d}$ representam a condutância e a capacitância distantes do corpo celular. Nesse neurônio também existe uma sinapse excitatória distal, longe do corpo celular, representada pela condutância $g_{e}$ e pela bateria $V_{e}$ (o potencial de equilíbrio), e uma outra sinapse inibitória próximal, mais próxima do corpo celular, representada pela condutância $g_{i}$ e pela bateria $V_{i}$. Além disso, $\phi_{p}$ corresponde à tensão próxima do corpo celular, $\phi_{d}$ corresponde à tensão em uma região distante do corpo celular e $\phi_{0}$ corresponde à tensão fora da membrana, que se pode associar ao terra do circuito (ou zero volts). Assumindo que $g_{e}$ e $g_{i}$ são constantes, e suponto $V_{i}=V_{C l}$, pode-se determinar, para esse circuito, $v_{p}=V_{p}-V_{C l}$, obtendo (GABBIANI; COX, 2010):

$$
v_{p}=\frac{g_{c} g_{e} v_{e}}{\left(g_{c}+g_{p}+g_{i}\right)\left(g_{c}+g_{d}+g_{e}\right)-g_{c}^{2}}
$$


com $v_{e}=V_{e}-V_{C l}$. Supondo que a condutância $g_{e}$ pode ser arbitrariamente elevada ${ }^{1}$ obtém-se:

$$
\lim _{g_{e} \rightarrow \infty} v_{p}=\frac{g_{c} v_{e}}{g_{c}+g_{p}+g_{i}}
$$

Essa última relação é chamada de propriedade de veto da inibição próxima: pode-se fazer a condutância $g_{i}$ ser grande o suficiente para anular a excitação $v_{e}$ no neurônio. Esse modelo elétrico simples mostra como duas áreas aparentemente diferentes do conhecimento (neurociência e circuitos elétricos) podem cooperar para se tirarem conclusões úteis sobre a natureza do sistema nervoso.

Por outro lado, modelos baseados em circuitos elétricos são modelos macroscópicos, construídos de forma top-down. Isso não é necessariamente um problema, mas pode limitar o modelo caso se queira levar em consideração aspectos microscópicos do neurônio. Por exemplo, suponha que se queira modelar o efeito de algum tipo de droga no neurônio. Suponha ainda que essa droga altere o comportamento dos canais de forma não linear (ou até mesmo não contínua). Em um modelo baseado em circuitos elétricos, seria necessário incluir condutâncias que simulem o efeito da droga em um conjunto de canais (potencialmente, essa condutância também seria baseada em uma função não linear e desconhecida a priori, o que pode gerar problemas para o algoritmo de integração).

Em vez de se utilizar uma abordagem macroscópica, em que o modelo não simula diretamente o comportamento de cada canal, mas apenas o comportamento agregado de um grande grupo de canais (que é o caso das condutâncias no modelo de Hodgkin e Huxley), pode-se construir um modelo que simule o comportamento de cada canal isoladamente, inclusive simular como uma droga afeta o comportamento de cada canal. O comportamento do conjunto completo de canais vai dar origem às diversas alterações na tensão da membrana, que podem ser medidas em laboratório e comparadas com os valores do modelo. Essa abordagem, do tipo botton-up, é a abordagem que é utilizada no presente trabalho. Adicionalmente, pode-se encarar a construção de modelos como um problema inverso: ou seja, dado um conjunto de dados obtidos em laboratório, busca-se um modelo (matemático ou computacional) que tenha um comportamento similar e reproduza os dados obtidos (CANNON; D’ALESSANDRO, 2006).

\footnotetext{
1 As sinapses inibitórias no corpo celular do neurônio normalmente envolvem íons de cloro, e podem ser
} bastante numerosas, tendo um efeito combinado de uma condutância elevada (GABBIANI; COX, 2010). 


\subsubsection{Considerações sobre os modelos baseados no trabalho de Hodg- kin e Huxley}

Hodgkin e Huxley ganharam o Prêmio Nobel de Medicina devido ao seu trabalho com o neurônio da lula. Eles construíram um modelo notável, sendo capazes de gerar um conjunto de equações com resultados numéricos próximos aos valores reais medidos. Seu sucesso é inegável, e o objetivo dessa seção não é, de forma alguma, desmerecer esse grande feito. Contudo, existem alguns problemas que devem ser observados.

O primeiro problema se refere à natureza do modelo, em que vários parâmetros não possuem significado físico direto: alguns coeficientes simplesmente foram ajustados para que o resultado final fosse similar às curvas levantadas em laboratório. Isso não é um "problema", pelo menos do ponto de vista de obtenção de resultados numéricos, e foi sem dúvida algo importante no início da neurociência, mas é importante lembrar que essa abordagem aponta mais para uma forma de ajuste de dados do que um modelo baseado em considerações físicas. Modelos de caráter físico são uma espécie de realização numérica da teoria, baseada em seus princípios. Na física, em geral, os modelos matemáticos são obtidos à partir de considerações teóricas. Fórmulas empíricas podem ser muito úteis, especialmente do ponto de vista de engenharia, mas elas tendem a ser fragmentos isolados e não uma base conceitual. Por outro lado, desde a sua concepção inicial, muito foi dito no sentido de se justificar o modelo de neurônio de Hodgkin e Huxley, e certamente hoje é possível encontrar uma explicação (algumas de caráter físico) para boa parte dos seus parâmetros.

Um dos aspectos contraditórios do modelo é que as resistências, do ponto de vista elétrico, apenas dissipam calor. Dessa forma, o modelo de Hodgkin e Huxley prevê um gasto energético muito maior que o real. Alguns estudos indicam que o modelo de Hodgkin e Huxley prevê uma dissipação de calor incompatível com os valores medidos (ANDERSEN et al., 2009; HOWARTH et al., 1968; HOWARTH, 1975; TASAKI et al., 1989; TASAKI; BYRNE, 1992; APPALI et al., 2012). Além disso, o modelo não é capaz de simular o comportamento da anestesia, o que levou à criação do modelo de sóliton do neurônio (HEIMBURG; JACKSON, 2005; ANDERSEN et al., 2009; HEIMBURG, 2008), que não é universalmente aceito pelos neurocientistas ${ }^{2}$. Esses esforços, no sentido da construção de

\footnotetext{
2 A lei de Meyer-Overton (MEYER, 1937) é uma regra empírica que relaciona o coeficiente de partição óleoágua de um anestésico e sua potência em um organismo. Essa lei, de caráter empírico, é difícil de ser explicada cientificamente. Vários modelos buscam explicar o mecanismo exato de funcionamento dessa relação, como o modelo de Cantor (1997) assim como os modelos baseados em sólitons.
} 
novos modelos, devem ser apreciados, uma vez que a Ciência é feita de questionamentos, que podem levar a revoluções no seu desenvolvimento (KUHN; HACKING, 2012).

Outro problema da abordagem de Hodgkin e Huxley é que o modelo precisa ser constantemente modificado para prever o comportamento de neurônios que não sejam o neurônio da lula. Na realidade, mesmo um comportamento básico como a adaptação (a mudança da frequência de disparos com o tempo) não foi originalmente obtida pelo modelo padrão de Hodgkin e Huxley. Para tal, é necessário incorporar a existência de outros canais ou outros mecanismos (CONNOR et al., 1977). O modelo de Ermentrout (1998) adiciona a concentração de cálcio para gerar o processo de adaptação. Contudo, a constante adição de novos termos, como o efeito das concentrações iônicas, faz com que o modelo se torne cada vez mais complexo. Em alguns casos, até mesmo regras do tipo se, então são adicionadas às equações diferenciais, tornando a resolução dessas equações (ainda) mais problemática, e aumentando de forma considerável a complexidade do modelo. Para aliviar esse problema, algumas simplificações podem ser feitas no modelo original, obtendo-se modelos mistos (BRETTE; GERSTNER, 2005).

Isso nos leva a um outro problema, de caráter prático: a resolução das equações de Hodgkin e Huxley é computacionalmente complexa ${ }^{3}$ (IZHIKEVICH, 2007). Considerando a propagação espacial, deve-se buscar uma solução numérica cuidadosa, caso contrário, o programa simplesmente não converge para a solução real. A adição de novos canais e mecanismos de adaptação agrava ainda mais o problema.

O modelo original não leva em consideração os aspectos espaciais do neurônio, como a sua geometria (o modelo original supunha uma geometria linear simples). Costuma-se tirar proveito disso: um neurônio real é divido em compartimentos equipotenciais, cada um correspondendo a uma particular instância do modelo de Hodgkin e Huxley. O problema é que isso faz com que um neurônio seja na realidade composto não apenas de uma equação diferencial, mas na prática dezenas ou mesmo centenas, dependendo da quantidade de compartimentos e do tamanho (ou geometria) do neurônio. A complexidade computacional pode crescer de forma considerável (HERZ et al., 2006; GERSTNER; NAUD, 2009; GERSTNER et al., 2012; STERRATT et al., 2011).

Também é preciso ter em mente o fato de que os parâmetros medidos na abordagem original são macroscópicos. Essencialmente, as condutâncias representam o comportamento global (ou médio) de todos os canais. O comportamento individual dos canais é perdido, restando apenas o resultado final agregado do modelo. Isso pode ser remedi-

\footnotetext{
3 Aqui refere-se ao modelo espacial completo, e não ao modelo voltage-clamp, que é bem mais simples de ser calculado.
} 
ado adotando-se modelos estocásticos, contudo, mesmo nessas circunstâncias, tem-se um problema: se o modelo corresponder ao comportamento de um segmento muito pequeno de membrana, e portanto se for baseado em poucos canais, a validade do modelo passa a ser limitada, tornando o resultado final de utilidade questionável: no limite, para um único canal, o modelo é completamente errado: um canal nunca se encontra meio aberto. Dessa forma, a variável que representa a condutância deveria variar em níveis discretos, e o formalismo da equação (agora uma equação de diferenças, e não mais uma equação diferencial) seria diferente. Se por outro lado, for modelado um grupo grande de canais, perdem-se informações locais, pois nesse caso está sendo simulado um trecho maior de membrana. Deve-se ressaltar que se está lidando com um meio em que a eletricidade não se propaga de forma perfeita.

Normalmente, esse último problema é resolvido com uma aproximação que é considerada "boa o bastante". O critério corresponde simplesmente ao quão próximo dos resultados experimentais o modelo se encontra. Contudo, pode-se perguntar: seria o objetivo de um modelo apenas reproduzir os resultados experimentais? Se a resposta for sim, então por que se preocupar em fazer um modelo que apenas repete o conhecimento que já se tem? Qual seria a vantagem nisso?

Finalmente, um último problema não está no modelo em si, mas no fato de que existe uma quantidade enorme de modelos derivados, que simplesmente adicionam "alguma característica útil" ao modelo original de Hodgkin e Huxley, com o objetivo de incorporar alguma informação adicional ou melhorar a aderência aos resultados obtidos em laboratório (o livro de Koch e Segev (1998) possui vários exemplos dessa natureza). Isso certamente tem algum valor, mas é importante se perguntar até quanto vale a pena considerar originais os trabalhos que simplesmente são variações em cima de um tema que é constantemente repetido e reinterpretado há mais de meio século.

O objetivo dessas críticas, como já dito anteriormente, não é desmerecer o modelo original de Hodgkin e Huxley, mas sim de contextualizar um problema: esse modelo não é a única forma de abordar um neurônio. Modelos simplificados, como o de Izhikevich (2003) ou o modelo integrate-and-fire são úteis pela sua simplicidade e elegância. O modelo de Izhikevich (2003), por exemplo, pode ser considerado um exemplo de simplicidade e elegância, mantendo um bom grau de realismo na modelagem. 


\title{
3.3 Exemplos de alguns modelos em neurociência
}

\author{
The mechanical brain does not secrete \\ thought "as the liver does bile", as the \\ earlier materialists claimed, nor does it \\ put it out in the form of energy, as the \\ muscle puts out its activity. Information \\ is information, not matter or energy.
}

Norbert Wiener

A premissa básica do modelo proposto nessa tese é de que o comportamento básico do neurônio (ao menos do ponto de vista do processamento da informação) é fundamentalmente determinado pelo comportamento dos canais presentes na sua membrana. Essa premissa, ainda que forte, é amplamente ancorada na visão científica atual da dinâmica dos neurônios (KANDEL et al., 2012), e possui a vantagem de possibilitar um caminho para o entendimento do funcionamento do neurônio. Evidentemente que outros fatores também complementam ou alteram essa dinâmica. Por exemplo, substâncias químicas podem alterar o funcionamento dos canais (por exemplo, o comportamento de substâncias como os endocanabióides). Porém, o modelo aqui proposto busca focar no comportamento dos canais iônicos como a unidade básica de processamento e propagação da informação. Muitas das substâncias químicas que alteram o comportamento global do neurônio essencialmente afetam o comportamento dos canais, e esses, por sua vez, alteram o comportamento do neurônio.

A estrutura básica do presente modelo é muito similar a de um automato celular (ILACHINSKI, 2001). Esse tipo de modelagem não é a mais popular na área de neurociência, mas os esforços mais significativos nesse sentido são brevemente detalhados a seguir.

O modelo CoDi (GERS et al., 1998) é um modelo de rede neural baseado em autômatos celulares. Nesse caso, a arquitetura da rede neural é formada pelo reticulado do autômato celular, e cada célula (do autômato) pode representar o corpo do neurônio, o axônio, o dendrito ou um espaço vazio (sem nenhuma célula). A conectividade é sempre local, o que facilita a simulação em máquinas paralelas. Contudo, esse modelo vem sendo utilizado mais como um paradigma de computação do que como um modelo biológico.

No artigo de Avella et al. (2008) é proposto um modelo simplificado de uma junção neuromuscular, utilizando uma estratégia baseada em autômatos celulares. Contudo, o utilização do automato celular se restringia ao processo de difusão, e o funcionamento dos 
canais e receptores foi baseado em um modelo cinético anterior (ANDERSON; STEVENS, 1973). O trabalho de Cheng et al. (2007) segue uma abordagem similar.

Alguns modelos procuram focar em reproduzir o comportamento de uma área cerebral grande, como o córtex visual (HOFMANN, 1987). Nesses casos, cada célula do autômato celular simula não apenas uma única célula do cérebro, mas um conjunto de células de uma dada região. Essa abordagem possui suas vantagens, especialmente do ponto de vista do desempenho computacional, mas o modelo é muito menos específico que o modelo apresentado no presente trabalho, buscando simular diretamente aspecto comportamentais. Outros modelos, como o proposto por Tatsuno et al. (2001), baseado em um sistema de regras, procuram simular a rede neural do hipocampo.

No artigo de Volk (2001), cria-se um modelo de neurônio muito simples, cujo potencial de ação é uma variável binária, e com um período refratário. O objetivo é modelar não apenas um único neurônio, mas o comportamento de um conjunto de neurônios, uma rede, buscando identificar sincronismos que levem ao comportamento epilético. De forma similar, há modelos que procuram simular aspectos da dinâmica de uma população grande de neurônios, especialmente buscando fazer paralelos com medidas de eletroencefalogramas (EEGs), como o modelo de Acedo (2009).

Outros modelos, como o de Martins e Monteiro (2013), estudam a dinâmica da rede com relação ao efeito da sua arquitetura básica e à sincronização dos seus diversos neurônios. Nesse modelo, investigou-se a ocorrência de sincronismo entre duas redes neurais, essencialmente representando o núcleo geniculado lateral e o córtex visual de um mesmo hemisfério cerebral.

Com relação à modelagem específica dos canais, existem alguns (poucos) modelos deterministas, como os mostrados no capítulo The physical basis of ion channel kinetics: the importance of dynamics de Layton e Weinstein (2002). Nesse capítulo, os autores procuram mostrar a importância de como um modelo determinista e com dinâmica caótica pode ser utilizado para modelar o comportamento dos canais iônicos. Os autores buscam ressaltar que características não lineares das moléculas envolvidas podem levar a comportamentos bastante complexos. Os modelos apresentados não são baseados em autômatos celulares, mas buscam utilizar sistemas deterministas na sua modelagem.

Existem artigos que comparam os resultados dos diversos modelos de canais, como 0 trabalho de Sansom et al. (1989). Contudo, a comparação procura levar em consideração mais a precisão numérica do que a simplicidade ou o grau de realismo físico dos modelos. Vale ressaltar que ao fim desse artigo, os autores preferem os modelos baseados em cadeias de Markov (e portanto de caráter estocástico). 
Dessa forma, é possível observar duas grandes estratégias de modelagem. Uma estratégia macroscópica, em que se simula o comportamento do neurônio de forma global, ou seja, com um conjunto de equações diferenciais simulando completamente o comportamento do neurônio. O modelo de Hodgkin e Huxley é o exemplo clássico dessa abordagem (HODGKIN; HUXLEY, 1952), e até hoje vem sendo a base para a construção de muitos outros modelos (como boa parte dos modelos discutidos por Sterratt et al. (2011) e por Gabbiani e Cox (2010)). Mas existe também uma abordagem mais granular, que corresponde a dividir o neurônio em compartimentos e criar modelos para cada um desses compartimentos; contudo, mesmo nesses casos, a descrição corresponde a um trecho grande de membrana em relação ao número de canais.

Uma outra possível estratégia para a simulação de neurônios seria uma de natureza totalmente microscópica, trabalhando no nível atômico, fazendo uma simulação direta dos átomos que compõem o canal, a membrana e os meios externos e internos. Existem diversas abordagens para esse tipo de simulação, como se pode ver em Becker et al. (2001), Adcock e McCammon (2006) e Roux (2002). Nesses casos, foram feitas simulações computacionais biofísicas que são extremamente fiéis aos dados coletados em laboratório (de um único canal), e podem-se obter resultados extremamente úteis na caracterização dos canais do ponto de vista microscópico.

A simulação de canais é alvo de muitas pesquisas, e diversas abordagens podem ser utilizadas, dependendo do poder computacional disponível, do grau de realismo que se busca com o modelo ou da necessidade em se reproduzir resultados de medidas de laboratório. Alguns artigos apresentam uma lista de diversos tipos de modelos, com os artigos de Levitt (1999) e o de Capener et al. (2002). A base comum desses modelos consiste em uma detalhada simulação molecular do comportamento do canal, envolvendo técnicas como (LEVITT, 1999):

- Solução exata da dinâmica molecular;

- Abordagem baseada no movimento browniano tridimensional;

- Abordagem tridimensional de Poisson-Nernst-Planck;

- Abordagem unidimensional de browniana e de Poisson-Nernst-Planck;

- Abordagem baseada na taxa de reação.

Essas técnicas permitem a simulação detalhada de um canal iônico, como descrito nas seções 2.3.1 e 2.3.2. O objetivo desse tipo de modelo é simular o comportamento de 
um único canal por um período de tempo relativamente curto (da ordem de centenas de nanosegundos). Porém, quando se busca considerar um conjunto grande de canais em um período longo de tempo (da ordem de milissegundos), essas abordagens tornam-se computacionalmente inviáveis. O principal objetivo dessas abordagens não é a simulação de um trecho grande de membrana, muito menos de um único neurônio, mas sim em apenas entender a estrutura física de um (único) canal. Mesmo utilizando várias máquinas em um cluster de alto desempenho, é apenas possível simular o funcionamento de alguns milhares (ou, em um futuro, milhões) de átomos, o que significa que o número de canais a ser simulado (e o tamanho da membrana) é muito pequeno. Diante dessa realidade, a possibilidade de simular um neurônio completo, ou ainda uma rede de neurônios, torna-se remota.

Contudo, a simulação com precisão atômica só faz sentido se o problema a ser pesquisado requerer este tipo de precisão. Isso pode ser necessário para a construção de modelos de um único canal, mas não para o funcionamento de um (ou mais) neurônio(s). Muitos dos modelos atuais de neurônios, mesmo os modelos compartimentais, não são construídos na escala atômica.

A dificuldade em entender e trabalhar com o mundo microscópico levou à construção de modelos estocásticos. A utilização desses modelos constitui uma forma de se modelar a complexidade dos fenômenos atômicos microscópicos que caracterizam a membrana e os canais. Dessa forma, o modelista pode "esquecer" parte da complexidade atômica e simplesmente utilizar as probabilidades como uma forma de simular uma série de comportamentos cuja verdadeira natureza se desconhece (ou se ignora).

Deve-se ressaltar que uma outra abordagem possível está em se enxergar o problema da propagação (ou da geração) de um sinal no neurônio como um problema de meios excitáveis. Essa foi a abordagem seguida por N. Wiener e A. Rosenblueth, que publicaram, em 1946, um artigo propondo um modelo para a contração do músculo cardíaco (WIENER; ROSENBLUETH, 1946; LETICHEVSKII; RESHODKO, 1972). Há quem ainda atribua a esse artigo o início da cibernética, como pode-se ver em (LETICHEVSKII; RESHODKO, 1972). De forma similar, mas tratando de um problema um pouco diferente, tem-se também o artigo de A. Turing sobre a morfogênese (TURING, 1952). O modelo de Wiener e Rosenblueth tem um forte caráter contínuo, e não pode ser visto como um autômato celular. A completa discretização do modelo foi dada posteriormente por Greenberg e Hastings (1978).

A abordagem utilizada na presente tese é uma espécie de abordagem microscópica simplificada, que contém alguns elementos dos vários modelos apresentados. Adota- 
se um modelo simples de canal, que possa ser rapidamente simulado, e com estados que tenham uma correspondência com o comportamento real dos canais. Dessa forma, assume-se que o comportamento do global do neurônio seja um fenômeno emergente do comportamento dos canais (um epifenômeno). Busca-se um modelo de canal que seja suficientemente simples para explicar os fenômenos macroscópicos observados nos neurônios, levando em consideração aspectos físicos microscópicos que se conhece sobre o comportamento dos canais.

\subsection{Justificativa para a estratégia utilizada}

Para criar um modelo de algum fenômeno físico é necessário que se possua um bom conhecimento do comportamento do sistema que se pretende modelar. Para modelar um neurônio, devemos nos questionar: qual é a melhor forma de começar? Uma vez que um neurônio é essencialmente dividido em axônio, corpo celular e dendritos, deve-se escolher qual dessas partes vai ser inicialmente modelada.

Ao se iniciar a modelagem pelo corpo celular, deve-se levar em consideração as complexas reações bioquímicas nas quais o corpo celular está envolvido, lembrando que é nessa região que o núcleo se encontra, e é nessa região onde ocorre a produção de diversas proteínas necessárias ao funcionamento da célula (que depois podem ser transportadas para outras regiões, caso necessário). Além disso, deve-se levar em consideração o efeito de sinapses inibitórias (que frequentemente ocorrem no corpo celular) e pensar em como o corpo celular vai "decidir" sobre o disparo ou não do potencial de ação. Como o corpo celular tem um papel de integrador de sinais (vindo dos dendritos), é preciso pensar em como esse processo de incorporação e integração vai ser feito, e como esse processo vai disparar o potencial de ação. Assim, percebe-se que, para modelar o corpo celular, é necessário identificar previamente um modelo adequado dos dendritos, do axônio e das sinapses.

As sinapses são mais do que simples conexões, mas constituem verdadeiros elementos computacionais (ABBOTT; REGEHR, 2004; PELAEZ; ANDINA, 2013), sendo altamente não lineares. Como as sinapses frequentemente conectam axônios com dendritos, é preciso identificar a influência de um no outro. As sinapses também são influenciadas por outros fatores, inclusive o meio intercelular.

Algumas pesquisas indicam que os dendritos possuem um papel importante na memória (HÄUSSER, 2004; FRICK et al., 2004; GOLDING et al., 2002) e possuem uma forma limitada de potencial de ação (chamada de dendritic spikes). Dessa forma, pode-se per- 
ceber que os dendritos têm um papel mais sofisticado do que uma simples "antena" que conduz sinais para o corpo celular.

Nesta tese, o axônio é tomado como um ponto de partida para a modelagem do neurônio. Existem alguns motivos para essa decisão. Em primeiro lugar, é possível encontrar muitos dados de diferentes pesquisas feitas sobre axônios (inclusive, deve-se lembrar que boa parte das primeiras pesquisas experimentais feitas em neurociência começaram justamente com os axônios, especialmente devido ao seu diâmetro maior). Em segundo lugar, os axônios possuem um comportamento mais previsível e estereotipado: o potencial de ação é um evento claro e distinto, e quando não há potencial de ação, seu comportamento é gradativo (também chamado de graded potentials).

\subsection{A abordagem seguida no presente trabalho}

O abordagem utilizada na presente pesquisa envolve a conexão entre o comportamento microscópico dos canais com o comportamento macroscópico da membrana e do neurônio. Ao se iniciar o modelo por um elemento altamente caracterizado (o axônio), é possível identificar, ao longo das diversas etapas de modelagem, se o modelo proposto está caminhando em uma direção certa ou errada.

A abordagem para a modelagem dos dendritos foi uma variação da abordagem utilizada para o axônio: com outros tipos de canais e com uma menor quantidade desses. Esse modelo pode ser refinado posteriormente, conforme a necessidade.

A modelagem das sinapses foi posterior ao modelo do axônio e do dendrito, e foi feita tendo-se em mente um tipo específico de neurônio e de neurotransmissor. Do ponto de vista de implementação, as sinapses são uma variação do modelo do axônio, já que o comportamento das sinapses também decorre do comportamento microscópico dos seus elementos constituintes. Porém, aqui, os canais têm um comportamento muito diferente, sendo especialmente sensíveis a um neurotransmissor. Além disso, nas sinapses (especialmente no terminal pré-sináptico) o cálcio tem um papel fundamental, influenciando diretamente na quantidade de neurotransmissores liberados na fenda sináptica (BEAR et al., 2007). As vesículas que liberam os neurotransmissores são controladas devido à ação de proteínas chamadas SNAREs (ou Soluble NSF Attachment protein REceptor), que controlam o processo de exocitose (SUTTON et al., 1998; BEAR et al., 2007). Essas proteínas são influenciadas pela concentração de cálcio, que indica quanto e por quanto tempo o processo de exocitose deve ocorrer (BEAR et al., 2007). Deve-se lembrar que a concentração do cálcio dentro do neurônio é muito baixa, e uma pequena quantidade de cálcio 
é suficiente para disparar uma série de reações químicas e mudanças na forma de várias proteínas.

Assim, o modelo completo do neurônio incorpora:

- um modelo de potencial de ação, se propagando ao longo do axônio (o potencial de ação afeta a abertura dos canais do terminal pré-sináptico);

- o comportamento da entrada do cálcio e da liberação das vesículas (que contêm uma quantidade fixa de neurotransmissores);

- o modelo da difusão dos neurotransmissores na fenda sináptica e do seu tempo de duração nessa mesma;

- um modelo da parte pós-sináptica.

Uma das funções da conexão (sinapse química) entre neurônios é a geração do chamado potencial pós-sináptico (BEAR et al., 2007; KANDEL et al., 2012). O potencial excitatório pós-sináptico (PEPS) representa um estímulo que tende a aumentar a chance de disparo do neurônio seguinte. Já o potencial inibitório pós-sináptico (PIPS) tem o efeito inverso, diminuindo sua chance de disparo. Dessa forma, o efeito da sinapse em um neurônio pode ser uma pequena despolarização ou hiperpolarização, dependendo da quantidade e do tipo de neurotransmissor liberado (que também é uma função do tipo da sinapse).

O corpo celular é o local onde os estímulos de diversas sinapses vindas dos dendritos são combinados, e vão influenciar no chamado cone axonal (ou, no inglês, axon hillock), levando (ou não) ao disparo de um potencial de ação. Além disso, o corpo celular pode conter sinapses inibitórias, que têm o efeito de neutralizar o disparo de um potencial de ação em determinadas condições.

Esses elementos formam a base de um modelo computacional completo de neurônio, baseado diretamente no comportamento dos canais, dos neurotransmissores e da eventual difusão de algumas substâncias dentro da célula e na fenda sináptica. Como esse modelo incorpora os elementos necessários à interconexão dos neurônios, existe a possibilidade de integrar esse modelo em uma rede virtual de neurônios. Por exemplo, pode-se aplicar algum estímulo de entrada e observar o comportamento de como as sinapses alteram e/ou propagam esse estímulo entre os diversos neurônios, e pode-se também tentar identificar como se estabelece (ou não) um padrão de disparo (spikes) nessa rede virtual. 


\subsection{Modelos cinéticos}

Anyone who considers arithmetical methods of producing random digits is, of course, in a state of sin.

John von Neumann

Uma pergunta que pode ocorrer ao se analisar a estrutura do modelo apresentado neste trabalho: qual é a relação entre o modelo proposto e os modelos cinéticos? Existem algumas semelhanças, mas também existem importantes diferenças.

Ainda que o modelo proposto possua várias similidades com os modelos cinéticos e com os modelos baseados em cadeias de Markov (especialmente os exemplos no capítulo 8 de Bower e Bolouri (2001) ), o modelo do presente trabalho é totalmente determinista. Isso pode ser considerado uma vantagem, dado que o computador que roda as simulações também é totalmente determinista (ele apenas pode produzir números pseudoaleatórios, e não realmente aleatórios). Além disso, se a simulação for executada duas ou mais vezes, ela deve produzir os mesmos resultados, ou o programa está com algum erro.

Em um modelo cinético tradicional, a transição de um estado para outro segue uma abordagem probabilista, e no caso dos modelos baseados em cadeias de Markov, a transição de um estado para outro depende apenas do estado atual (e das probabilidades associadas com esse estado, evidentemente). Isso significa que esses modelos dependem:

- da correta identificação dos vários estados;

- de uma clara descrição desses estados;

- de uma forma de estimar as probabilidades associadas ao modelo;

- de um bom gerador de números pseudoaleatórios.

Além disso, quando se modela um canal iônico baseado em uma cadeia de Markov, assume-se que as probabilidades de transição de estado não possuem memória dos momentos anteriores, dado que a transição de estado depende apenas do estado atual e das probabilidades. Dessa forma, esses modelos assumem que os canais iônicos não possuem memória (KEW; DAVIES, 2010). Essa aproximação pode ser válida em muitas circunstâncias, como é indicado pela popularidade desses modelos (ZHENG; TRUDEAU, 2015; STERRATT et al., 2011; GABBIANI; COX, 2010; SANSOM et al., 1989). Por outro 
lado, essa aproximação pode ser questionada em algumas circunstâncias, como é o caso dos modelos fractais (LOWEN et al., 1997, 1999).

Nesse ponto, é preciso lembrar que uma célula possui várias formas de memória: as concentrações de substâncias químicas, por exemplo, podem funcionar como uma espécie de memória de eventos anteriores. Os processos de adição ou remoção do elemento fósforo de diversas moléculas também funcionam como uma espécie de memória (vide os diversos exemplos de LTP ${ }^{4}$ e LTD ${ }^{5}$ em Bear et al. (2007) ).

Em algumas circunstancias, compensa-se a inexistência de memória entre os estados (nos modelos baseado em cadeias de Markov) incorporando mais estados. Por exemplo, o modelo cinético no qual o canal de sódio é equivalente ao modelo de Hodgkin e Huxley (FITZHUGH, 1965) é representado pelo diagrama mostrado na figura (3.4).

Figura 3.4: Modelo de cadeia de Markov do canal de sódio, baseado no modelo determinista de Hodgkin e Huxley, obtido inicialmente em Fitzhugh (1965)

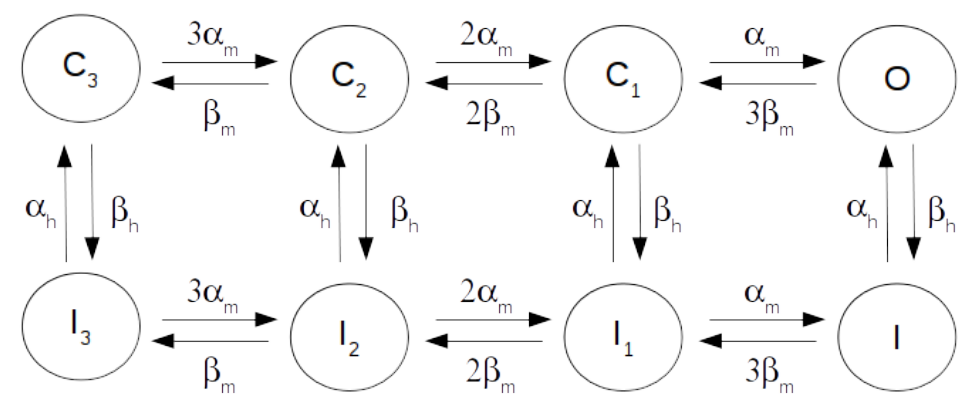

Fonte: Adaptado de Bower e Bolouri (2001).

Esse modelo tem várias similaridades com o modelo básico de Hodgkin e Huxley, mas deve-se observar que o número de estados teve que crescer, mesmo para uma modelagem relativamente simples como a indicada. Nessa figura, os estados que começam com a letra C representam os estados "fechados", I representam os estados "inativados" (quando o canal está fechado e está em um estado refratário, muito mais difícil de abrir) e $\mathrm{O}$ corresponde ao estado "aberto". As diversas variáveis $\alpha$ e $\beta$ têm o papel das probabilidades de mudança de estados. A necessidade de se modelar canais com comportamentos mais complexos leva à adição de novos estados, o que pode levar a uma explosão combinatorial , tornando a modelagem difícil de ser compreendida (BOWER; BOLOURI, 2001). Esse é um outro problema com os modelos baseados em cadeias de Markov: a proliferação

\footnotetext{
4 LTP quer dizer long-term potentiation.
}

5 LTD quer dizer long-term depression. 
dos estados. As probabilidades são convenientes para modelar a complexidade de algo que não se tem uma descrição completa, ou cuja descrição detalhada seria absurdamente longa. Mas se o próprio modelo probabilista passa se tornar complexo, a sua utilidade pode ser questionada.

No próximo capítulo descreve-se o modelo proposto e as justificativas das diversas decisões tomadas no seu desenvolvimento. 


\section{Capítulo 4}

\section{O modelo do axônio}

Remember that all models are wrong; the practical question is how wrong do they have to be to not be useful.

George E. P. Box

Neste capítulo, descreve-se como foi modelado o axônio. O potencial de membrana do axônio tem um comportamento estereotipado e representa um ponto de partida para a construção de modelos de neurônios. Os resultados apresentados neste capítulo foram publicados em dois artigos na revista Applied Mathematics and Computation (CORREALE; MONTEIRO, 2016, 2017)

\subsection{Propondo um modelo}

A estrutura básica do modelo apresentado consiste na divisão da membrana em pequenas regiões quadradas, similar ao reticulado de um autômato celular. Cada região, por sua vez, possui um conjunto de canais, que podem ser do mesmo tipo ou não. Diferentes regiões (trechos ou quadrados do reticulado) podem ter diferentes potenciais elétricos, mas todos os canais dentro de uma mesma região estão sujeitos ao mesmo potencial elétrico. A disposição geométrica dos canais dentro de uma região não é relevante, uma vez que cada região possui um mesmo valor de potencial elétrico e um mesmo valor de concentrações de substâncias químicas, de forma que um aumento da concentração de um íon (por exemplo, o cálcio) é percebida da mesma forma por todos os canais dentro de uma dada região. Assim, a discretização da membrana é um aspecto fundamental do modelo: quanto menor a região, maior a resolução e o realismo da simulação, porém, o custo computacional também aumenta. Nas simulações apresentadas, cada quadrado tem dimensões de 
$100 \mu m \times 100 \mu m$, e por representarem uma região equipotencial, essas dimensões devem ser inferiores ao comprimento eletrotônico do neurônio. Uma representação gráfica do modelo geométrico da membrana do axônio pode ser vista na figura (4.1).

Figura 4.1: Modelo do axônio e sua discretização.

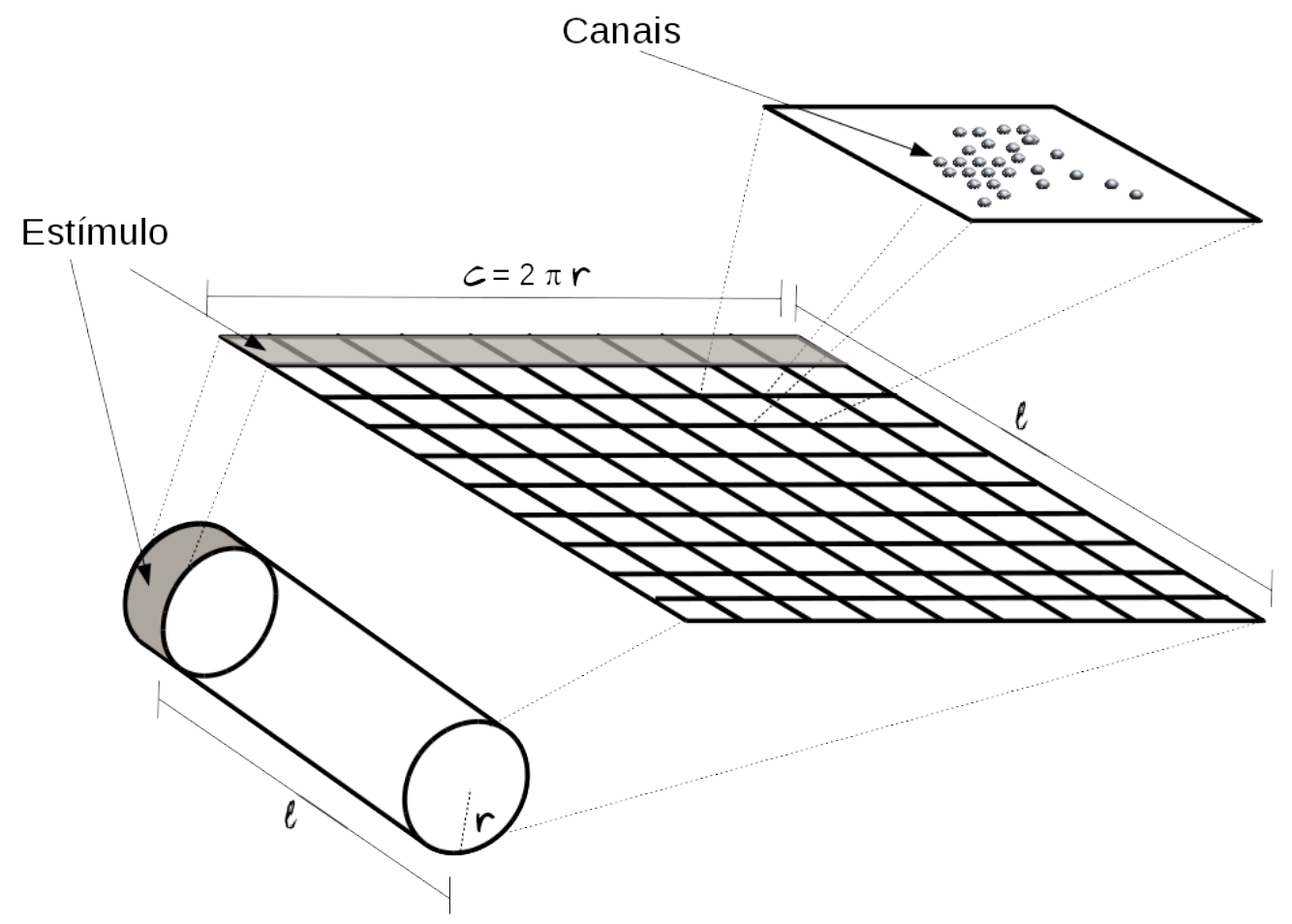

Fonte: Autor.

Quando um trecho de membrana não possui canal iônico, a sua tensão é determinada pela interação com os trechos vizinhos. Cada quadrado possui uma capacitância e o seu potencial é definido de acordo com a lei do capacitor: $Q_{\text {memb }}=C_{\text {memb }} \times V_{\text {memb }}$, em que $Q_{\text {memb }}$ é a quantidade de cargas acumuladas no trecho de membrana, $C_{m e m b}$ é a capacitância correspondente dessa área e $V_{\text {memb }}$ é a tensão da membrana (no trecho em questão). Cada trecho de membrana pode trocar cargas apenas com os seus vizinhos a norte, sul, leste e oeste, em um processo difusivo. A troca de cargas pode carregar (ou descarregar) eletricamente a membrana, alterando o seu potencial.

Em uma célula real, o efeito dos canais iônicos é permitir a entrada seletiva de íons dentro da célula. Cada canal iônico possui uma seletividade, ou seja, permite a passagem preferencial de alguns tipos íons e bloqueia a passagem de outros tipos. Dessa forma, um canal de sódio permite a passagem preferencial de íons de sódio, sendo a passagem de 
outros tipos de íons muito mais difícil (BEAR et al., 2007; KANDEL et al., 2012; STERRATT et al., 2011).

Sabe-se que a concentração dos íons do lado de dentro e de fora da membrana é bastante diferente. Essa diferença é principalmente fruto de dois processos: a presença das chamadas bombas iônicas e a permeabilidade seletiva da membrana (devido aos canais iônicos). Ao se observar as concentrações iônicas em um neurônio típico (como mostrado na tabela (2.1)), pode-se perceber, por exemplo, que a concentração interna do potássio (dentro da célula) é muito maior que a concentração externa. Dessa forma, existe uma tendência natural da difusão de íons do lado com maior concentração para o lado com menor concentração.

Quando uma célula precisa deslocar íons no sentido oposto ao seu gradiente de concentração, algum mecanismo ativo (que consome energia) deve entrar em ação. É para essa finalidade que existem proteínas na membrana como as bombas iônicas e os transportadores (Van Winkle, 1999; CLARKE; KHALID, 2015). Essas proteínas podem funcionar consumindo ATP ou por meio da troca de íons (no caso dos anti-transportadores (SIGEL et al., 2016)).

A ação conjunta dos canais iônicos e das bombas faz com que a membrana de uma célula neuronal possua um potencial de repouso por volta de $-65 \mathrm{mV}$. Dessa forma, existe uma concentração maior de cargas negativas no interior da célula do que no seu exterior.

Contudo, vale ressaltar que na construção do modelo proposto no presente trabalho, não foi necessária a inclusão de bombas iônicas, o que é justificado por duas razões. Primeiro, o intervalo de execução das simulações é pequeno o bastante para que a dinâmica das bombas iônicas não seja relevante. Em segundo lugar, deve-se ter em mente que uma característica do modelo proposto é que ele não armazena a concentração de cada íon, mas sim a concentração de cargas. O modelo impõe que, na situação de repouso, a tensão da membrana seja de $-65 \mathrm{mV}$. Essa imposição de tensão de repouso corresponde ao restabelecimento das concentrações iniciais iônicas pelas bombas iônicas.

Em uma membrana real, conforme a concentração de um dado íon vai se tornando igual em ambos os lados da célula, a força de caráter difusivo vai diminuindo. Contudo, no modelo proposto, apenas a proporção de canais iônicos é relevante para modificação da tensão da membrana, e não a concentração de cada íon. Dessa forma, no modelo proposto, quando os canais voltam para o estado fechado e a membrana volta para o repouso, é como se as bombas já tivessem entrado em ação e reconstruído os gradientes de concentração iniciais. 


\subsubsection{A origem do potencial elétrico da membrana}

Se a membrana de um neurônio for deixada em repouso, passado algum tempo (e supondo condições estáticas de condutividade), obtém-se uma situação de equilíbrio (JOHNSTON; WU, 1995; STERRATT et al., 2011). Deve-se destacar o fato de que o potencial de equilíbrio é diferente para cada tipo de íon, uma vez que a concentração dos íons é diferente no interior e no exterior da célula, e a condutividade dos canais é seletiva. Em muitos casos, a seletividade não se aplica apenas ao tipo de íon, mas também à direção (por exemplo, apenas entrada ou saída de íons da célula, existindo também canais permeáveis nos dois sentidos). Dessa forma, se permite que o sistema evolua continuamente até o equilíbrio entre essas duas forças, e para um dado tipo de canal iônico, o potencial da membrana tenderia ao potencial de equilíbrio do íon em questão.

Contudo, uma membrana não possui apenas um tipo de canal iônico, mas vários. Além disso, esses canais não ficam abertos o tempo todo ${ }^{1}$, fechando após algum tempo, devido a mudanças no ambiente físico a sua volta (como uma mudança de tensão da membrana, ou outra interação de natureza química ou mesmo mecânica). Ao se levar em conta a dinâmica dos canais, somada a sua diversidade, percebe-se que o potencial de membrana é o resultado da ação conjunta de diversos fatores.

Em um modelo microscópico preciso, a concentração de cada tipo de íon seria registrada de forma separada, bem como a permeabilidade da membrana para cada tipo de íon, e finalmente o potencial de membrana poderia ser calculado pela equação (2.11) de Goldman-Hodgkin-Katz. Essa abordagem, ainda que válida, é computacionalmente cara. Mesmo o modelo de condutâncias de Hodgkin e Huxley é muito mais simplificado do que isso, pois trabalha com condutâncias, em vez de permeabilidades e concentrações.

O presente modelo representa uma outra abordagem para essa simplificação. De forma similar aos modelos cinéticos, cada canal iônico possui um estado. Também é possível adicionar diversidade à população de canais, que não precisam ser absolutamente iguais nem precisam necessariamente compartilhar o mesmo estado. Por exemplo, em uma dada região da membrana, parte dos canais de sódio pode estar aberta e parte pode estar fechada, dependendo de seus parâmetros e do seu histórico de ativação. Contudo, diferentemente dos modelos cinéticos, o funcionamento dos canais é determinista e baseado em um conjunto de regras (comandos if), levando em consideração a tensão local ou a concentração de algum íon ou substância química (dependendo da natureza do canal em questão). Os canais também possuem memória. Por exemplo, certos canais podem ficar

Existem alguns tipos de canais que ficam sempre no estado aberto ou fechado (RIGATOS, 2014), mas no momento isso não é relevante para essa etapa da modelagem. 
em um determinado estado por um período de tempo especificado, tendo uma espécie de "cronômetro" que controla a duração desse intervalo.

Quando um dado canal iônico está no estado aberto, ele influencia a membrana fazendo com que o potencial elétrico do trecho de membrana onde o canal se encontra tenda ao potencial do equilíbrio do íon ao qual o canal é mais permeável. Dessa forma, para o canal de sódio, ele tende a deslocar o potencial de membrana em direção ao potencial de equilíbrio do íon de sódio. Como a membrana possui mais de um tipo de canal, o potencial final da membrana vai depender da proporção de canais abertos para cada tipo de íon. Por exemplo, se mais canais de potássio estiverem abertos do que de canais de sódio, o potencial de membrana tende a se deslocar em direção ao potencial de equilíbrio do potássio.

Se um canal iônico estiver fechado (ou em qualquer outro estado diferente do estado aberto) ele contribui como se fosse um trecho de membrana passivo (ou seja, ele contribui para deslocar o potencial de membrana em direção ao potencial que seria obtido por uma membrana de natureza puramente passiva, o potencial de equilíbrio da membrana).

O passo de tempo da simulação é de $1 \mu s$, um valor suficientemente pequeno para garantir uma boa resolução temporal, mas não excessivamente pequeno a ponto de tornar as simulações muito longas. Quanto menor o passo de tempo, maior é o número de iterações necessárias para simular um mesmo intervalo de tempo físico (real).

Cada canal iônico é modelado como um agente independente (seguindo uma abordagem similar aos modelos baseados em agentes (RAILSBACK; GRIMM, 2011; WILENSKY; RAND, 2015), possuindo as seguintes características:

Tipo de canal: O tipo de canal está ligado à sua forma de funcionamento, podendo ser sensível à tensão de membrana ou canais de vazamento (que estão sempre no estado aberto).

Íon associado: Cada canal permite a passagem de um tipo específico de íon, sendo que no modelo apresentado nesse capítulo consideram-se apenas os íons de sódio e potássio. Além disso, considera-se que um canal trabalha exclusivamente com um único tipo de íon, uma simplificação da realidade.

Estado: Em toda iteração do modelo, um canal iônico possui um estado associado. O repertório de estados pode variar dependendo do tipo de íon associado ao canal e do tipo de canal, porém, de forma geral, três estados são utilizados: aberto, fechado e inativado. 
Limiar de abertura: No caso dos canais sensíveis à tensão, o limiar de abertura corresponde à tensão de membrana na qual o canal muda de estado, de fechado para aberto. Esse parâmetro é baseado no ponto médio de ativação do canal iônico (CONLEY; BRAMMAR, 1999), dado em $m V$.

Intervalo de abertura: Quando um canal encontra-se no estado aberto, ele permanece nesse estado por um tempo determinado, mudando para um outro estado (fechado ou inativado, dependendo do canal) quando esse tempo expira. Esse parâmetro é dado em iterações e é um dos "cronômetros" fundamentais do modelo.

Atraso de abertura: Mesmo após o limiar de abertura ter sido alcançado, o canal pode não abrir imediatamente, levando um tempo para mudar a sua conformação molecular. Esse atraso representa esse tempo de mudança de conformação. Esse parâmetro também é dado em número de iterações.

Período de inatividade: Alguns canais (como o canal de sódio) possuem um estado similar ao estado fechado, na qual o canal não permite a passagem de íons. Assim, nesse estado, uma tensão que normalmente seria suficiente para permitir a abertura do canal não tem o efeito desejado. Esse é um dos fenômenos que leva ao chamado período refratário do potencial de ação disparado pelos neurônios. Também é dado em número de iterações.

Nas próximas seções, descrevem-se os modelos utilizados para os canais de sódio sensível à tensão e para o canal de potássio sensível à tensão. Nessas seções, a densidade de canais de sódio por trecho de membrana é chamada de $d_{N a}$, a densidade de canais de potássio por trecho de membrana é chamada de $d_{K}$, o número de células na direção longitudinal do axônio de $n_{x}$ e o número de células na direção transversal de $n_{y}$.

\subsubsection{A dinâmica dos canais}

\section{O canal iônico de potássio sensível à tensão}

Para o canal de potássio sensível à tensão, adotaram-se três possíveis estados: "fechado", "abrindo" e "aberto". A ordem de ativação é: fechado $\longrightarrow$ abrindo $\longrightarrow$ aberto $\longrightarrow$ fechado. O estado padrão é o estado fechado, no qual o canal se encontra normalmente (e permanece nesse estado por um período de tempo indeterminado). Como o canal modelado é sensível à tensão, a transição do estado "fechado" para o estado "abrindo" ocorre devido a uma mudança na tensão da membrana ao redor do canal. No modelo proposto, 
esse é o limiar de abertura e é medido como a tensão do trecho de membrana (quadrado) no qual o canal está inserido.

Quando a tensão do trecho de membrana em que o canal se encontra se torna maior que o limiar de abertura $E_{\text {LimAbertK }}$, o canal muda para o estado "abrindo". Esse estado representa sua configuraçao durante o intervalo de tempo que o canal leva para mudar a sua forma, normalmente um período muito curto (apenas uma iteração nas simulações do presente trabalho), definido como $\tau_{\text {abrindoK }}$ (o atraso de abertura). Contudo, durante o estado "abrindo", o comportamento do canal continua sendo idêntico ao do estado fechado. O próximo estado é "aberto". O tempo que o canal permanece nesse estado é definido pelo parâmetro $\tau_{\text {abertoK }}$ (o intervalo de abertura). Terminado esse período, o canal volta para o estado inicial "fechado". Pode-se sintetizar essas transições por meio da seguinte função de transição de estados:

$$
s_{K}(t+1)= \begin{cases}\text { fechado, } & \text { se }\left(E_{\text {memb }}[t]<E_{\text {KLimAbert }} \wedge s_{K}[t]=\text { fechado }\right) \\ & \vee\left(t_{\text {aberto }} \geq \tau_{\text {Kaberto }} \wedge s_{K}[t]=\text { aberto }\right) \\ \text { abrindo, }, & \text { se }\left(s_{K}[t]=\text { fechado } \vee s_{K}[t]=\text { abrindo }\right) \\ & \wedge\left(t_{\text {abrindo }}<\tau_{\text {Kabrindo }}\right) \\ \text { aberto }, & \text { se }\left(t_{\text {aberto }}<\tau_{\text {Kaberto }}\right) \wedge\left(s_{K}[t]=\text { aberto }\right) \\ & \left.\vee\left(t_{\text {abrindo }} \geq \tau_{\text {Kabrindo }}\right) \wedge s_{K}[t]=\text { abrindo }\right)\end{cases}
$$

$\mathrm{Na}$ equação (4.1), o símbolo $\wedge$ significa o operador lógico "e", enquanto o símbolo $\vee$ significa o operador lógico "ou". O estado do canal de potássio é denotado por $s_{K}$.

\section{O canal iônico de sódio sensível à tensão}

O canal de sódio possui quatro estados: "fechado", "abrindo", "aberto" e "inativado", seguindo a seguinte ordem de ativação: fechado $\longrightarrow$ abrindo $\longrightarrow$ aberto $\longrightarrow$ inativado $\longrightarrow$ fechado. Observe que existe um estado a mais que no canal de potássio, o estado "inativado". Os estados "fechado", "abrindo" e "aberto" funcionam de forma similar aos estados correspondentes do canal de potássio. Contudo, após o estado "aberto", o canal de sódio muda temporariamente para o estado "inativado". Nesse estado, o canal se comporta como se estivesse fechado, porém, mesmo que a tensão de membrana se torne superior ao limite de abertura $E_{\text {NaLimAbert }}$, o canal não permite a passagem de íons, e continua se comportando como se estivesse fechado, ficando nesse estado até o final do intervalo de tempo definido por $\tau_{\text {NaInativado }}$ (o período de inatividade). Após esse período, o canal volta ao estado fechado, ficando nesse estado indefinidamente, até o potencial de membrana 
Tabela 4.1: Descrição dos intervalos de tempo utilizado no modelo para cada tipo de canal.

\begin{tabular}{|l|l|l|}
\hline Cronômetro & Tipo do Canal & Descrição \\
\hline$\tau_{\text {Kaberto }}$ & $\mathrm{K}$ & Intervalo de tempo do estado "aberto". \\
\hline$\tau_{\text {Kabrindo }}$ & $\mathrm{K}$ & Intervalo de tempo do estado "abrindo". \\
\hline$\tau_{\text {NaAbrindo }}$ & $\mathrm{Na}$ & Intervalo de tempo do estado "abrindo" \\
\hline$\tau_{\text {NaAberto }}$ & $\mathrm{Na}$ & Intervalo de tempo do estado "aberto". \\
\hline$\tau_{\text {NaInativado }}$ & $\mathrm{Na}$ & Intervalo de tempo do estado "inativado". \\
\hline
\end{tabular}

Fonte: Autor.

$E_{m e m b}[t]$ ser superior ao limiar de abertura $E_{\text {NaLimAbert }}$. A função de transição de estado para $s_{N a}$ é dada por (4.2):

$$
s_{N a}(t+1)=\left\{\begin{aligned}
\text { fechado, }, & \text { se }\left(E_{\text {memb }}[t]<E_{\text {NaLimAbert }} \wedge s_{\text {Na }}[t]=\text { fechado }\right) \\
& \vee\left(t_{\text {inativado }} \geq \tau_{\text {NaInativado }} \wedge s_{N a}[t]=\text { inativado }\right) \\
\text { abrindo, }, & \text { se }\left(E_{\text {memb }}[t] \geq E_{\text {NaLimAbert }}\right) \wedge\left(s_{N a}[t]=\text { fechado } \vee s_{N a}[t]=\text { abrindo }\right) \\
& \wedge\left(t_{\text {abrindo }}<\tau_{\text {NaAbrindo }}\right) \\
& \text { se }\left(t_{\text {aberto }}<\tau_{\text {NaAberto }}\right) \wedge\left(s_{N a}[t]=\text { aberto }\right) \\
& \left.\vee\left(t_{\text {abrindo }} \geq \tau_{\text {abrindo }}\right) \wedge s_{N a}[t]=\text { abrindo }\right) \\
\text { aberto } & \text { se }\left(t_{\text {inactivated }}<\tau_{\text {NaInativado }}\right) \wedge\left(s_{\text {Na }}[t]=\text { inativado }\right) \\
\text { inativado } & \left.\vee\left(t_{\text {aberto }} \geq \tau_{\text {NaAberto }}\right) \wedge s_{N a}[t]=\text { aberto }\right)
\end{aligned}\right.
$$

\section{A importância dos cronômetros}

Como pode ser observado, o presente modelo descreve a dinâmica dos canais de uma forma determinista e baseada em intervalos de tempo, que aqui se chamam de cronômetros. Excetuando-se o estado fechado, todos os demais estados possuem uma duração pré-determinada. Esses intervalos de tempo são descritos na tabela (4.1).

Os cronômetros $\tau_{\text {Kaberto }}$ e $\tau_{\text {NaAberto }}$ definem o tempo no qual a conformação do respectivo canal (sódio ou potássio) permite a passagem máxima de íons. Já os cronômetros $\tau_{\text {Kabrindo }}$ e $\tau_{\text {NaAbrindo }}$ têm um significado diferente: eles representam o tempo que o canal iônico leva para mudar a sua conformação, saindo do estado fechado para o estado aberto. Na prática, esse intervalo de tempo corresponde à um grande número de mudanças de conformação físicas, agrupadas no formato de um cronômetro, para simplificar a cons- 
trução do modelo. Adicionalmente, o cronômetro $\tau_{\text {NaInativado }}$ está intimamente relacionado ao período refratário, sendo um estágio intermediário de conformação do canal de sódio anterior ao estado fechado.

Os parâmetros utilizados foram retirados de medições vindas da literatura (como o livro Conley e Brammar (1999)), e podem ser estimados em laboratório. Uma forma de se estimar esses cronômetros é utilizando-se a técnica de patch clamp (SAKMANN; NEHER, 1984), e observando-se a evolução da variação da corrente elétrica ao longo do tempo para um valor específico de tensão. Dessa forma, um experimento de laboratório pode identificar os parâmetros do modelo proposto a partir de medidas físicas executadas em um dado organismo e em um tipo específico de tecido biológico.

\subsubsection{Características locais da membrana}

Uma dos principais objetivos na elaboração do presente modelo é descrever o comportamento elétrico da membrana. Como esse comportamento é fortemente influenciado pelos canais iônicos, uma grande parte do modelo foca nesse aspecto. Contudo, a membrana também é afetada por outros fatores e possui outras características importantes. No modelo proposto, essas características podem ser sumarizadas por:

Posição vertical e horizontal: Identifica o posicionamento do quadrado na superfície do neurônio, por meio de suas coordenadas $x$ e $y$.

Número de íons armazenados: Identifica a quantidade de cargas elétricas armazenadas no trecho específico de membrana, em coulombs.

O modelo proposto trabalha com a quantidade de cargas e não com a concentração específica de cada tipo de íon. Dessa forma, apenas um valor correspondente ao número de portadores de carga armazenados na membrana é levado em consideração (esse valor pode ser convertido para coulombs, multiplicando-se o número de íons armazenados pela carga fundamental do elétron). Em um modelo super-realista, a concentração de cada íon (sódio, potássio, entre outros) seria armazenada separadamente. A corrente poderia então ser calculada pela equação de corrente de Goldman-Hodgkin-Katz (GHK). Idealmente, os parâmetros difusivos do meio seriam armazenados separadamente para cada um dos íons. Esse processo seria, por outro lado, caro computacionalmente e necessitaria de muito mais memória para armazenar as concentrações iônicas de forma independente.

Aqui trabalha-se com uma simplificação desse cenário. Em vez de armazenar cada uma das concentrações iônicas, registra-se o valor de apenas uma variável, a quantidade 
de cargas trocadas. Essa variável (que é equivalente a corrente elétrica, mas trabalha diretamente com o número de portadores de cargas, em vez do valor da corrente elétrica em Ampères) representa o efeito conjunto de todas as concentrações iônicas de todas as cargas presentes em um determinado trecho de membrana. Além disso, essa variável pode ser positiva ou negativa. Finalmente, esse valor é multiplicado pela carga elementar do elétron. Essa simplificação diminui o espaço em memória necessário para o programa rodar (uma vez que as estruturas de dados do programa podem ser menores), e simplifica o algoritmo, já que se consideram menos variáveis.

Dependendo da situação que se quer modelar, pode ser necessário adicionar mais informações ao trecho de membrana. Por exemplo, no modelo de uma sinapse, em que o estado dos canais depende da concentração de substâncias químicas como neurotransmissores, podem-se adicionar tais informações ao trecho de membrana em questão. 0 cuidado que deve ser tomado, nesses casos, é que a concentração deve ser a mesma em todo o trecho: se o tamanho do trecho de membrana for muito grande, não valendo a aproximação de que a concentração de uma dada substância é a mesma em todo o trecho, deve-se buscar uma outra abordagem (ou diminuir o tamanho de cada quadrado na discretização). No presente trabalho, no capítulo seguinte, apresenta-se uma extensão ao presente modelo, que corresponde à adição de um "sub-reticulado", ou uma subdivisão interna do trecho, permitindo assim modelar uma distribuição não homogênea de uma substância (essa alteração será discutida no próximo capítulo).

\subsubsection{0 cálculo da tensão}

$O$ cálculo do potencial $E$ da membrana leva em consideração dois fatores:

- A influência passiva que cada um dos trechos de membrana tem sobre os seus vizinhos. Isso corresponde à passagem de corrente elétrica entre esses trechos, um processo (no caso dos neurônios) essencialmente difusivo. Aqui, chama-se essa influência de "potencial de membrana passivo", $E_{\text {pass }}$.

- O efeito local e não linear dos canais iônicos. Cada canal no estado aberto tende a deslocar a tensão do trecho de membrana em direção ao potencial de equilíbrio do ín ao qual o canal é mais permeável. Por outro lado, canais em qualquer estado diferente do estado aberto tendem a deslocar o potencial de membrana em direção ao potencial de membrana passivo.

O cálculo do componente passivo do potencial de membrana é similar ao cálculo da tensão em um capacitor. Em um dado instante de tempo $t$, calcula-se a quantidade de 
cargas presentes em um trecho específico de membrana, $\sigma_{\text {local }}[t]$. Para isso deve-se considerar a troca de íons entre os trechos vizinhos (nos modelos compartimentais, essa é a chamada corrente axial). Considera-se uma vizinhança do tipo de Von Neumann de raio unitário, tendo quatro vizinhos (exceto nas extremidades, onde existem apenas dois ou três vizinhos): norte $(i=1)$, sul (i=2), leste $(i=3)$ e oeste $(i=4)$.

Posteriormente, calcula-se a diferença de cargas entre o trecho de membrana em questão $\sigma_{\text {local }}[t]$ e o seu vizinho $\sigma_{i}[t]$, e uma parcela $\beta$ dessa diferença é trocada, sempre na direção do lado que possui menos cargas, recebendo cargas do vizinho que possua mais cargas. O total de cargas trocado entre um trecho de membrana e os seus vizinhos é dado por $\Delta_{\text {local }}[t]$ :

$$
\Delta_{\text {local }}[t]=\sum_{i=1}^{4} \beta\left(\sigma_{i}[t]-\sigma_{\text {local }}[t]\right)
$$

Finalmente, obtém-se o novo valor de $\sigma_{\text {local }}[t+1]$ fazendo: $\sigma_{\text {local }}[t+1]=\sigma_{\text {local }}[t]+\Delta_{\text {local }}[t]$. No modelo proposto, foi utilizado utilizado $\beta=0,15$ baseado no comportamento passivo observado em membranas reais (STERRATT et al., 2011; BEAR et al., 2007; NARAHASHI, 1963). Finalmente, sabendo-se o valor da capacitância do trecho de membrana $C_{m e m b}$, pode-se calcular o valor do potencial de membrana em um dado instante $t$ utilizando a fórmula: $E_{\text {pass }}[t]=\sigma_{\text {pass }}[t] / C_{m}$.

O componente não linear, devido à ação dos canais iônicos, é calculado utilizando a proporção de canais no estado aberto em relação ao número total de canais, para cada tipo de íon. Dessa forma, considerando-se que em um dado instante de tempo $t$ existe uma quantidade numNaAberto de canais de sódio no estado aberto, e um total de canais (de todos os tipos) totCan, calcula-se a proporção de canais de sódio no estado aberto por meio da fórmula: $p_{N a}[t]=$ numNaAberto[t]/totCan. Esse valor é então multiplicado pelo potencial de equilíbrio do sódio, $E_{N a}$. Essas proporções são então calculadas para cada um dos tipos de canais considerados no modelo (neste caso, para o sódio e o potássio).

Uma vez que tenha sido feito o cálculo da proporção de canais no estado aberto para cada tipo de íon, deve ser incorporada a influência dos canais nos demais estados e das características passivas da membrana. Os canais que se encontram em um estado diferente de "aberto" tendem a fazer o potencial de membrana se deslocar em relação ao valor $E_{\text {pass }}$, calculado anteriormente levando-se em conta apenas o componente passivo. Dessa forma, armazena-se na variável numCanNaoAberto o número de canais em algum estado diferente de aberto, para todos os tipos de canais, e com isso calcula-se a proporção $p_{\text {naoAb }}[t]=$ numCanNaoAbert $[t] /$ totCan . Esse valor é então multiplicado por $E_{\text {pass }}[t]$. Com 
o somatório do valor de todas as proporções envolvidas, é possível calcular o potencial objetivo $E_{o b j}[t]$, descrito pela equação (4.4):

$$
E_{o b j}[t+1]=p_{N a}[t] \times E_{N a}+p_{K}[t] \times E_{K}+p_{\text {naoAb }}[t] \times E_{\text {pass }}[t]
$$

com $E_{N a}=50 m V$ e $E_{K}=-72 m V$ (STERRATT et al., 2011; BEAR et al., 2007).

A equação (4.4) é mais simples de ser computacionalmente resolvida quando comparada com a solução numérica de equações diferenciais, que pode apresentar problemas de convergência e estabilidade numérica.

Contudo, essa estratégia ainda possui algumas desvantagens. Um problema encontrado foi que a taxa de variação da tensão de membrana se tornou muito elevada. Para resolver esse problema, foi estabelecido um valor máximo de $\frac{d E}{d t}$ de $200 \mathrm{~V} / \mathrm{s}$, baseado em valores similares aos encontrados em estudos de laboratório² (JOHNSON; MCKINNON, 1957; KISHIDA et al., 1979; SCHWARZ; PUIL, 1998).

Para incorporar a limitação no valor máximo de $\frac{d E}{d t}$, primeiro calcula-se $\Delta E[t+1]=$ $E_{o b j}[t+1]-E[t]$, com $E_{o b j}[t+1]$ sendo o valor obtido pela equação (4.4) e $E[t]$ sendo o valor do potencial de membrana no instante atual (ou seja, antes da atualização). Posteriormente, se o valor de $\Delta E[t+1]$ for maior que $\left.\frac{d E}{d t}\right|_{\max }=200 \mathrm{~V} / \mathrm{s}$, toma-se $\Delta E[t+1]=\left.\frac{d E}{d t}\right|_{\max }$ (que é igual a $200 \mathrm{~V} / \mathrm{s}$ ). Se $\Delta E[t+1]$ for menor que esse valor, mantém-se valor calculado de $\Delta E[t+1]$. O cálculo do potencial de membrana para a próxima iteração é então calculado como: $E[t+1]=E[t]+\Delta E[t+1]$. Esse é o motivo pelo qual se usa $E_{o b j}$ na equação (4.4), e não $E[t+1]$ : esse não é o valor final do potencial de membrana, mas sim o valor anterior a aplicação do fator limitante na derivada.

Adicionalmente, deve ser observado que o cálculo de $\Delta E[t+1]$ é feito a cada iteração do algoritmo, que representa um intervalo de tempo de $1 \mu \mathrm{s}$.

Finalmente, também levou-se em conta a presença dos canais de "vazamento", que são canais que estão permanentemente no estado aberto, independentemente da tensão de membrana ou outros fatores (GOLDSTEIN et al., 2001; BEAR et al., 2007; STERRATT et al., 2011). Uma provável utilidade desses canais é a estabilização do valor da tensão de repouso da membrana por volta de $-65 \mathrm{mV}$. Além disso, de acordo com (ROTH; HÄUSSER, 2005), a densidade de canais de vazamento afeta a resistência da membrana. $\mathrm{Na}$ abordagem padrão de Hodgkin e Huxley, esses canais costumam ser modelados como uma corrente de vazamento, normalmente chamada de $I_{\text {leak }}$, com um valor fixo de condutância associada (GABBIANI; COX, 2010; STERRATT et al., 2011). No modelo proposto, a presença de canais de vazamento é feita alterando-se a proporção de canais no estado

\footnotetext{
2 Lembrando que $200 \mathrm{~V} / \mathrm{s}=0,2 \mathrm{mV} / \mu \mathrm{s}$.
} 
aberto, $p_{N a}[t]$ e $p_{K}[t]$ : antes do cálculo de $E_{o b j}$ pela função (4.4), adiciona-se 0,000048 a $p_{N a}[t]$ e 0,0008 ao valor de $p_{K}[t]$. Isso ocorre mesmo quando todos os canais normais encontram-se no estado fechado, fazendo com que os valores mínimos de $p_{N a}[t]$ e $p_{K}[t]$ sejam 0,000048 e 0,0008, respectivamente. Esses valores foram ajustados por meio de simulações, com o objetivo de manter o potencial de repouso da membrana no valor usual de $-65 m V$.

\subsection{Resultados}

Para avaliar a dinâmica do modelo proposto, foram testados seis cenários diferentes:

- Simulação da membrana sem nenhum canal iônico, com o objetivo de avaliar o comportamento passivo da membrana;

- Simulação da membrana com apenas canais de sódio e com o potencial de membrana fixo em um valor (voltage clamp);

- Simulação com dois tipos de canais iônicos (sódio e potássio), com disparos do potencial de ação, mas sem fenômenos mais complexos, como adaptação;

- Simulação com dois canais iônicos e com a incorporação do fenômeno da adaptação da frequência dos disparos do potencial de ação;

- Simulação de neurônios com curva de corrente versus frequência de entrada, sendo que essa curva pode ser contínua ou descontínua;

- Comparação do formato do potencial de ação com dados gravados de neurônios reais.

É útil comparar os resultados obtidos com outros modelos, como o modelo padrão de Hodgkin e Huxley (1952) ou o modelo de membrana passiva de Rall (1969a). Os trabaIhos de Hodgkin e Huxley são muito conhecidos, e frequentemente outras pesquisas são comparadas com essa abordagem. Pode-se dizer que esse modelo é uma espécie de "referencial padrão" na área. O mesmo se aplica ao modelo de membrana passiva de Rall (1967, 1969a). Também é possível alterar o modelo proposto visando a reprodução de dados biológicos reais. Tendo esse objetivo em mente, compararam-se os resultados obtidos com dados biológicos disponíbilizados pelo projeto "CRCNS - Collaborative Research in Computational Neuroscience" (http://crcns.org/) (MIZUSEKI et al., 2009b, 2009a). 
As simulações foram feitas em um computador com microprocessador Intel Core i74770 (4 núcleos) com clock de $3.4 \mathrm{GHz}$ e 16 Gb de memória RAM, rodando o sistema operacional GNU/Ubuntu Linux versão 14.04 na sua versão de 64 bits. Os programas foram escritos na linguagem de programação Python (www.python.org), mas foi utilizado um interpretador especial, com melhor desempenho para operações numéricas, o interpretador Pypy (pypy.org).

Os valores dos parâmetros do modelo foram baseados em estudos da área. Por exemplo, o potencial de abertura dos canais iônicos (o potencial de membrana no qual o canal iônico se abre) foi baseado no valor do ponto médio de ativação, retirado de Conley e Brammar (1999). Para o neurônio olfativo de ratos, o ponto médio de ativação dos canais de sódio registrado é de $-45 \mathrm{mV}$, e aqui foi utilizado $-55 \mathrm{mV}$. Para o canal iônico de potássio, os valores dos canais codificados pela subfamília genética Kv3 possui ponto médio de ativação superior a $-10 m \mathrm{~V}$. No caso, foi utilizado um valor de $-5 \mathrm{mV}$. Os valores dos parâmetros utilizados nas simulações estão sumarizados na tabela (4.2).

Tabela 4.2: Parâmetros utilizados nas simulações.

\begin{tabular}{|c|c|}
\hline Parâmetro & Valor \\
\hline \hline atraso de abertura do canal de $\mathrm{Na}^{+}$ & $2 \mu \mathrm{s}$ \\
\hline limite de abertura do canal de $\mathrm{Na}^{+}$ & $-55 \mathrm{mV}$ \\
\hline intervalo de abertura do canal de $\mathrm{Na}^{+}$ & $450 \mu \mathrm{s}$ \\
\hline período de inatividade do canal de $\mathrm{Na}^{+}$ & $5500 \mu \mathrm{s}$ \\
\hline potencial de equilíbrio do íon $\mathrm{Na}^{+}$(STERRATT et al., 2011) & $50 \mathrm{mV}$ \\
\hline atraso de abertura do canal de $\mathrm{K}^{+}$ & $1 \mu \mathrm{s}$ \\
\hline limite de abertura do canal de $\mathrm{K}^{+}$ & $-5 \mathrm{mV}$ \\
\hline intervalo de abertura do canal de $\mathrm{K}^{+}$ & $2500 \mu \mathrm{s}$ \\
\hline período de inatividade do canal de $\mathrm{K}^{+}$ & $0 \mu \mathrm{s}$ \\
\hline potencial de equilíbrio do íon $\mathrm{K}^{+}$(STERRATT et al., 2011) & $-72 \mathrm{mV}$ \\
\hline capacitância da membrana (STERRATT et al., 2011) & $1 \mu \mathrm{F} / \mu \mathrm{m}^{2}$ \\
\hline área de cada trecho de membrana (quadrado) & $10000 \mu \mathrm{m}^{2}$ \\
\hline
\end{tabular}

\subsubsection{Simulações da membrana sem canais iônicos ativos}

Sem a presença de canais iônicos sensíveis à tensão (mas com os canais de vazamento), o comportamento do potencial elétrico da membrana neuronal é similar a um circuito elétrico RC, ou seja, do tipo resistor-capacitor. Estímulos externos ou pulsos se propagando através da membrana tendem a carregar o "capacitor", enquanto que a resistência da membrana (que representa as perdas internas naturais) tendem a dissipar parte 
dessas cargas. Além disso, parte dos íons se propagam para as proximidades do trecho de membrana.

\section{O modelo teórico de Rall}

No artigo de Rall (1969b) são analisadas algumas soluções matemáticas possíveis para o comportamento puramente passivo das membranas biológicas. Nesse artigo, o modelo do comportamento da membrana passiva segue a seguinte equação:

$$
\frac{\partial^{2} V}{\partial X^{2}}=V+\frac{\partial V}{\partial T}
$$

na qual $X$ corresponde a posição ao longo do eixo do cilindro, $V$ é a tensão da membrana e $T$ é o tempo. As condições de contorno são:

$$
\begin{aligned}
& \frac{\partial V}{\partial X}=0, X=0, T>0 \\
& \frac{\partial V}{\partial X}=0, X=L, T>0
\end{aligned}
$$

com $L$ sendo o comprimento do cilindro (ou axônio). Além disso, não existem estímulos externos e apenas a condição inicial é responsável pelo transitório de tensão na membrana. A tensão de repouso da membrana é de aproximadamente $-65 \mathrm{mV}$, e foi aplicada uma despolarização inicial para o valor de $0 \mathrm{~V}$. A geometria corresponde ao chamado sealed end, um cilindro fechado, significando que tanto o início quanto o final do cilindro permanecem no valor de repouso da membrana durante o experimento.

$\mathrm{Na}$ análise de Rall, as soluções para a equação (4.5), obtidas pelo método da separação de variáveis, sendo $\alpha^{2}$ a constante de separação, são da forma ${ }^{3}$ :

$$
V(X, t)=(A \sin (\alpha X)+B \cos (\alpha X)) e^{\left(-\left(1+\alpha^{2}\right) t\right) / \tau_{m}}
$$

De uma forma empírica, a caracterização da membrana pode ser feita por meio de dois parâmetros: a constante de tempo da membrana $\tau_{m}$ e o comprimento eletrotônico $\lambda_{m}$ (RALL, 1969b; LUDWIG, 2007; NARAHASHI, 1963).

3 No artigo de Rall (1969b) é feita uma normalização da variável temporal, com $T=t / \tau_{m}$, sendo $\tau_{m}$ a constante de tempo da membrana. O mesmo é feito com relação ao espaço, em que $X=x / \lambda_{m}$. 
Figura 4.2: Gráfico da potencial elétrico da membrana $E$ em um trecho central, utilizado para calcular $\tau_{m}$. Neste gráfico, a linha cheia corresponde aos resultados obtidos por meio da simulação do modelo proposto, enquanto os pontos identificados com um $\times$ representam os valores teóricos de acordo com o modelo de Rall. Nessa simulação, $n_{x}=80, n_{y}=5$, $d_{N a}=0$, e $d_{K}=0$.

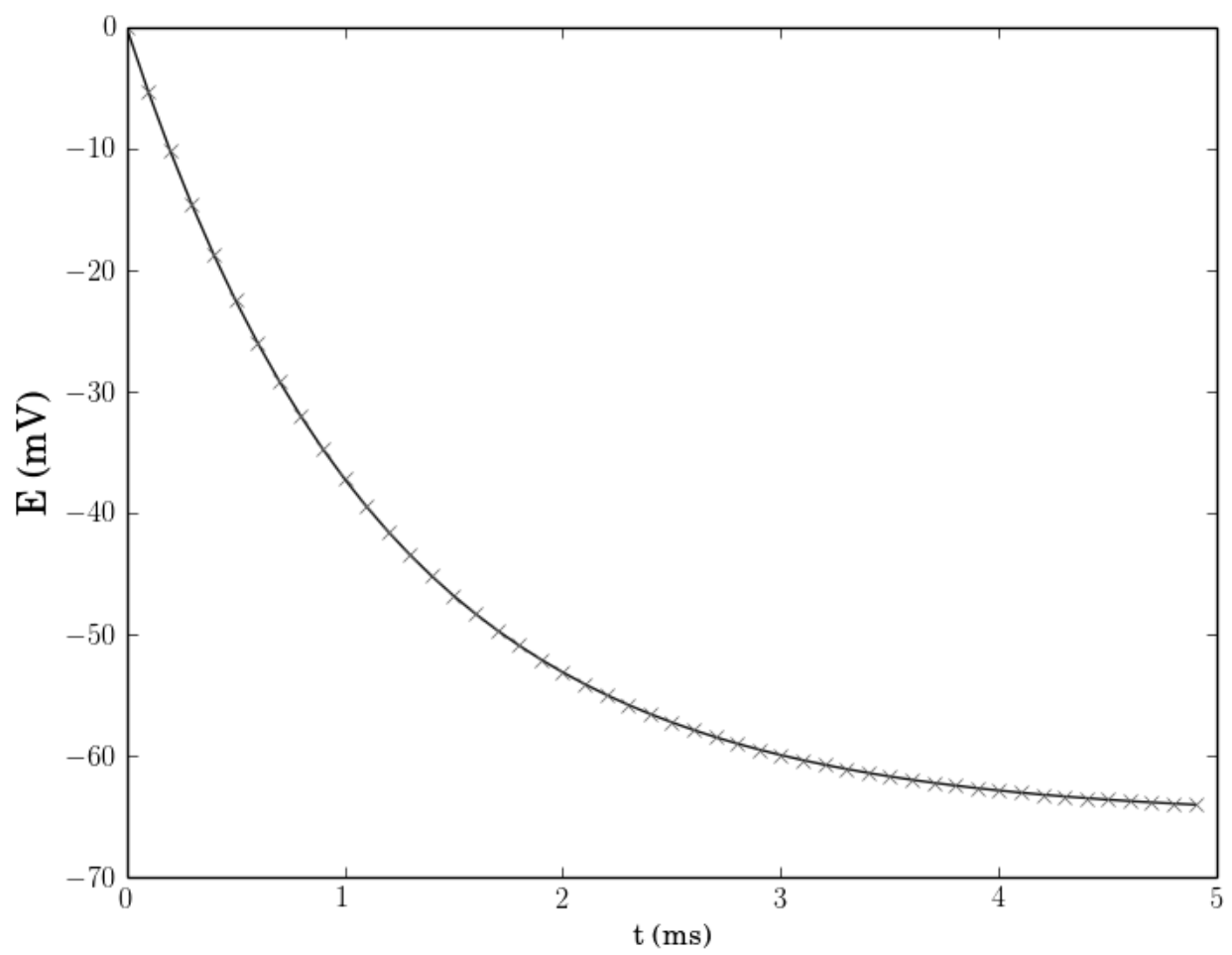

Fonte: Publicado originalmente em (CORREALE; MONTEIRO, 2016).

\section{Os resultados da simulação}

A fim de comparação, encontrou-se o valor de $\tau_{m}$ aplicando um pulso de tensão curto ${ }^{4}$ em toda a membrana, e foi medido o tempo de decaimento do potencial elétrico. Pode-se observar o resultado na figura (4.2) como a linha contínua. Nessa mesma figura, tem-se o gráfico da função (com $t$ em $m s$ e $v$ em $m V$ ):

$$
v_{1}(t)=-65+65 e^{\frac{-t}{1.18}}
$$

A função $v_{1}(t)$ (4.9) foi calculada por meio de um algoritmo simples de busca exaustiva com minimização de erro, em que o erro é o quadrado da subtração do resultado do valor da simulação menos o valor apresentado pela função candidata.

\footnotetext{
4 Por curto entende-se um estímulo de apenas duas iterações.
} 
A membrana simulada tem um comprimento de $8000 \mu n m$ e um perímetro de $500 \mu m$. A função exponencial (4.9) tem uma constante de tempo $\tau_{m}=1.18 m s$. Comparando os resultados obtidos com a análise previamente apresentada em Rall (1969a), observa-se que a equação (4.9) equivale ao modelo de Rall com $\alpha=0, B=-65 \mathrm{~V}$ e $\tau_{m}=1.18 \mathrm{~ms}$, indicando que o modelo proposto e o modelo de Rall são compatíveis.

A constante de membrana $\tau_{m}$ é definida como o capacitância da membrana multiplicada pela sua resistência (STERRATT et al., 2011). Estudos feitos com a lula (COLE; HODGKIN, 1939; HODGKIN et al., 1952) indicam uma condutância por unidade de área $1 / r_{m}$ de $1 / 700 \Omega^{-1} \mathrm{~cm}^{-2}$ e uma capacitância por unidade de área $c_{m}$ de $1 \mu \mathrm{F} / \mathrm{cm}^{2}$. Com esses valores, tem-se que $\tau_{m}=r_{m} \times c_{m}=0,7 m s$. O valor obtido de $1,18 m s$ está bastante próximo, especialmente levando em consideração que medidas como essas estão sujeitas a diversas formas de ruído, bem como variações nas condições de medida (como a temperatura).

Para obter-se o comprimento eletrotônico, deve-se identificar o quão "profundo" um estímulo em um ponto na membrana se propaga para os seus arredores (BEAR et al., 2007). Isso foi feito selecionando os dois primeiros "anéis" de trechos de membrana no início do axônio, mantendo um valor de tensão fixa nesse trecho, e observando como essa tensão decai ao longo do axônio. No caso, o trecho inicial do axônio é mantido em $0 \mathrm{~V}$ e os valores de tensão são medidos ao longo do comprimento do axônio. É importante ressaltar que a tendência da membrana é voltar para o seu potencial de repouso (no caso, $-65 \mathrm{mV}$ ). Os resultados são mostrados na figura (4.3). Nessa figura, além dos dados da simulação, mostra-se também uma curva dada pela seguinte equação (com $l$ em $\mathrm{mm}$ e $v$ em $\mathrm{mV}$ ):

$$
v_{2}(l)=-65+65 e^{\frac{-l}{1.33}}
$$

Obteve-se a função $v_{2}(l)$ utilizando o mesmo método anteriormente utilizado para o cálculo de $v_{1}(t)$ (essencialmente uma busca exaustiva). Dessa forma, é possível obter da equação (4.10) que $\lambda_{m}=1,33 \mathrm{~mm}$. Em Narahashi (1963) encontra-se uma tabela com o valor de $\lambda_{m}$, aqui parcialmente reproduzida na tabela (4.3).

$\mathrm{Na}$ figura (4.3) ilustra-se o gráfico do potencial de membrana após $5 \mathrm{~ms}$, ao longo do axônio. Devido à simetria do axônio, o mesmo resultado é encontrado em qualquer linha horizontal na direção do axônio. Para observar a distribuição do potencial ao longo de toda a membrana, na figura (4.4) mostra-se um mapa em escala de tons de cinza do potencial elétrico, também em $t=5 \mathrm{~ms}$. Na parte inicial do axônio, onde a figura possui um tom mais escuro, observa-se o ponto em que o estímulo foi aplicado, que gradualmente vai ficando mais claro, conforme o esperado. 
Figura 4.3: Gráfico do potencial de membrana ao longo da superfície do axônio, para o instante de tempo $t=5 \mathrm{~ms}$. Esses valores foram utilizados para a determinação de $\lambda_{m}$. Neste gráfico, a linha cheia corresponde aos resultados obtidos por meio da simulação do modelo proposto, enquanto os pontos identificados com um $\times$ representam os valores teóricos de acordo com o modelo de Rall. Os valores dos parâmetros utilizados foram os mesmos da figura (4.2).

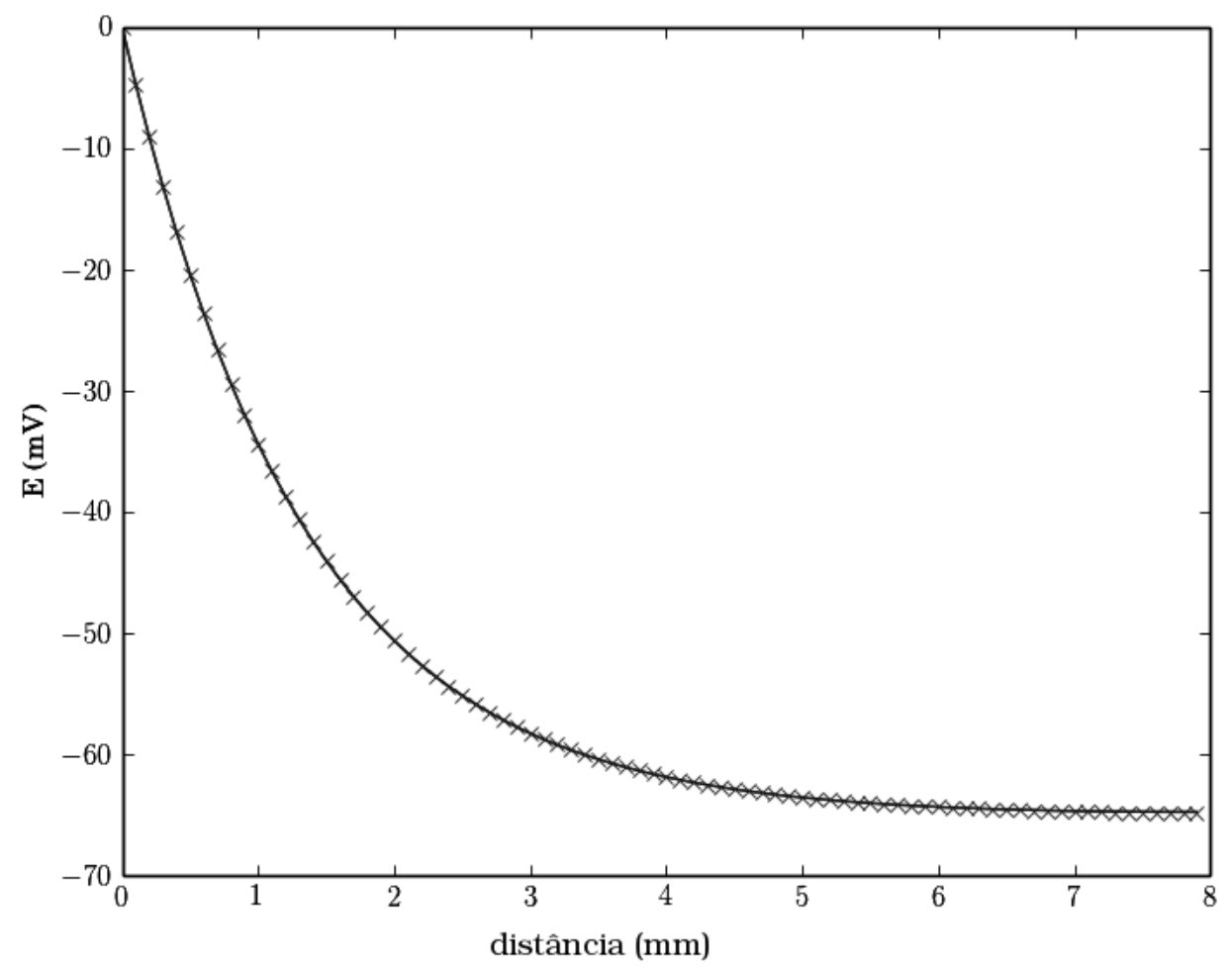

Fonte: Publicado originalmente em (CORREALE; MONTEIRO, 2016).

Tabela 4.3: Comprimento eletrotônico para diversos organismos (nervos e músculos).

\section{Espécie}

Axônio da lula (Loligo)

Axônio da lula (Sepia)

Axônio do caranguejo (Carcinus)

Axônio da lagosta (Homarus)

Músculo do sapo (Rana)

Músculo do caranguejo (Carcinus)

Célula de Purkinje de uma criança $\lambda_{m}(\mathrm{~mm})$

6,0

5,7

2,0

1,6

1,1

0,9

1,9

Fonte: Adaptado de (NARAHASHI, 1963). 
Figura 4.4: Distribuição do potencial de membrana $E$ ao longo do axônio também em $t=5 \mathrm{~ms}$ e com os mesmos parâmetros da figura (4.2).
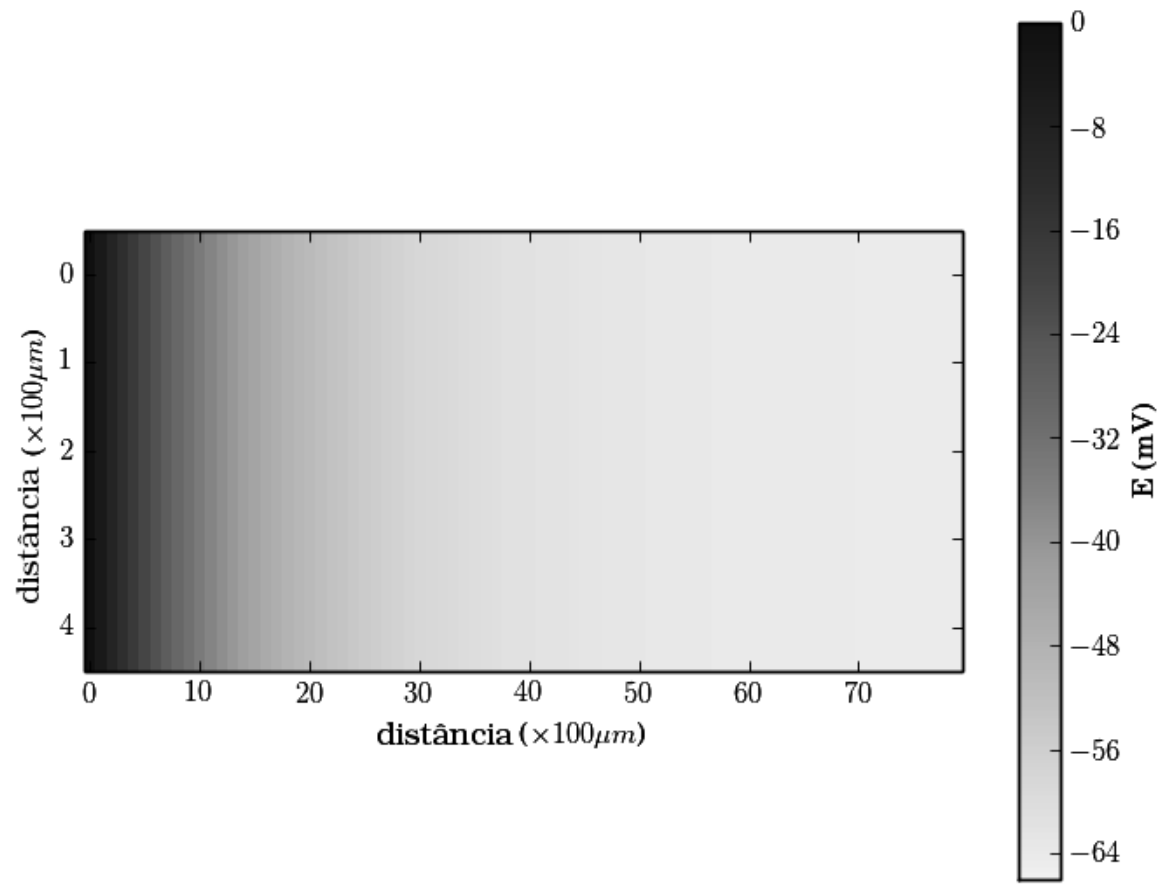

Fonte: Publicado originalmente em (CORREALE; MONTEIRO, 2016). 


\subsubsection{Simulação dos canais de sódio}

É possível contrastar o modelo proposto com a abordagem utilizando cadeias de Markov. Na abordagem markoviana, fala-se em diferentes estados e associa-se probabilidades às mudanças de estado. Nessa abordagem, a mudança em si não é determinista, e os tempos e condições de mudança de estado devem estar embutidas nas probabilidades associadas, ou em um modelo para o cálculo dessas probabilidades.

Existe uma ambiguidade inerente na construção de modelos utilizando cadeias de Markov, uma vez que cadeias diferentes podem ser capazes de reproduzir uma mesma forma de onda. Uma das abordagens mais simples capazes de reproduzir diversos aspectos dos canais de sódio presentes na membrana do neurônio da lula podem ser encontrados em Destexhe et al. (1994). Nesse artigo é proposto um modelo composto de apenas três estados e quatro transições, como ilustrado na figura (4.5).

Figura 4.5: O modelo proposto em (DESTEXHE et al., 1994). Na figura, c corresponde ao estado fechado, o corresponde ao estado aberto e i corresponde a inativado. As probabilidades de transição são determinadas pelos parâmetros $r_{1}(V), r_{2}(V), r_{3}$ e $r_{4}(V)$, sendo que os parâmetros $r_{1}, r_{2}$ e $r_{4}$ também dependem da tensão da membrana, enquanto $r_{3}$ é uma probabilidade fixa.

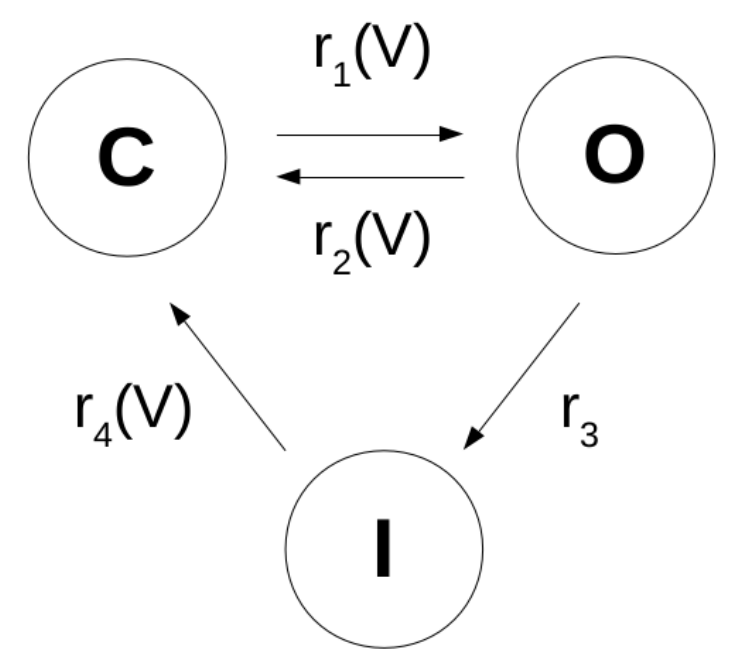

Fonte: Adaptado de (DESTEXHE et al., 1994).

A figura (4.6) representa a proporção de canais em cada um dos três possíveis estados, para o modelo de Destexhe et al. Foram simulados 5000 canais de sódio controlados por tensão, com a tensão de membrana fixa em $-20 m V$, por um intervalo total de tempo de $5 m s$. 
Figura 4.6: Simulação do modelo proposto em (DESTEXHE et al., 1994) com os seguintes parâmetros: $a_{1}=1500 / \mathrm{s}, a_{2}=200 / \mathrm{s}, a_{4}=150 / \mathrm{s}, b=5 \mathrm{mV}, c_{1}=c_{2}=-27 \mathrm{mV}, c_{4}=-65 \mathrm{mV}$ e $r_{3}=3000 / s$. Na figura, i significa o estado inativado, c significa fechado e o significa aberto.

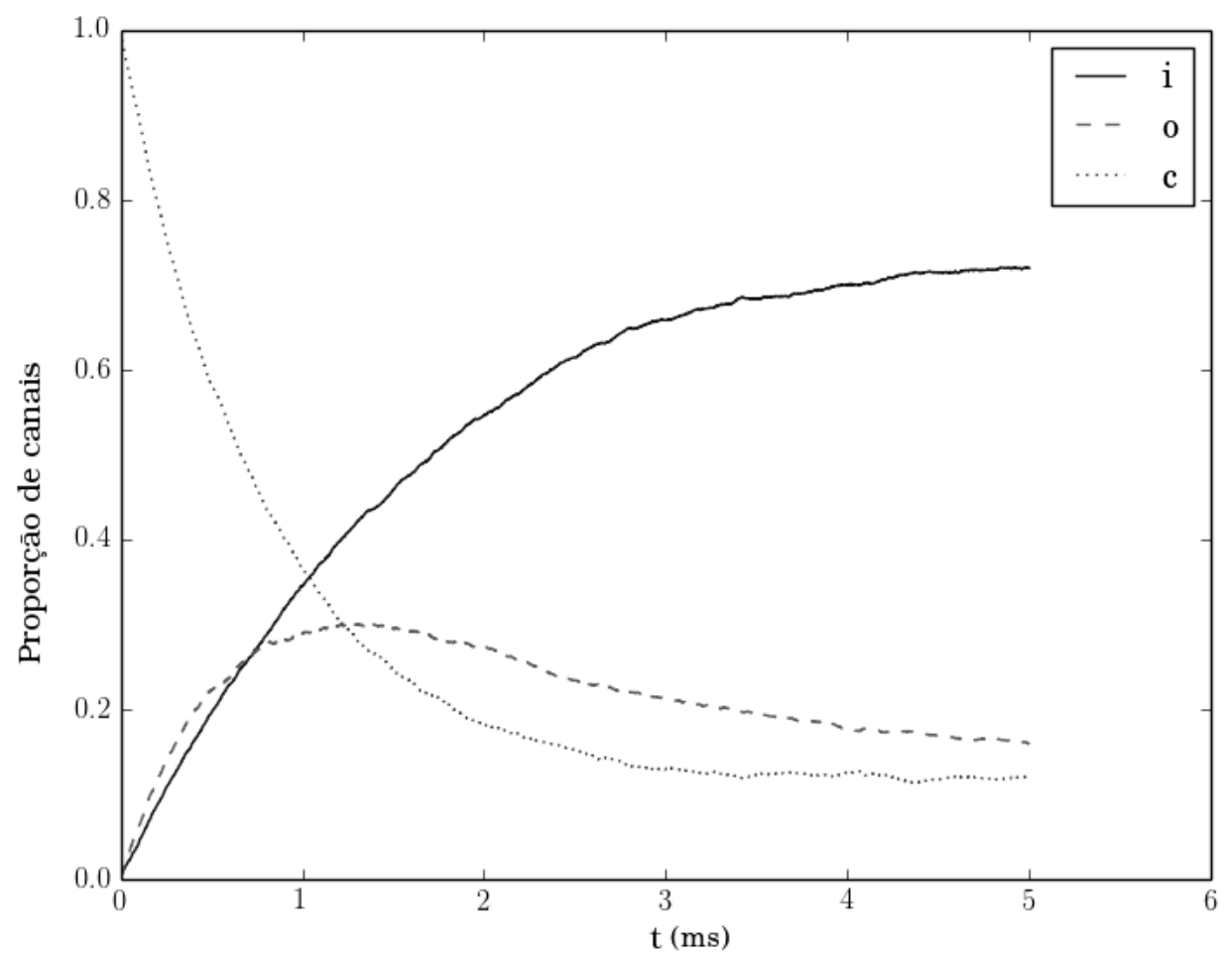

É possível construir um modelo similar ao apresentado em Destexhe et al. (1994), utilizando a abordagem proposta neste trabalho, como ilustrado na figura (4.7).

Pode-se observar que o resultado obtido na figura (4.7) representa uma aproximação linear por trechos do modelo apresentado por Destexhe et al. Nessa simulação também foram simulados 5000 canais, mas como o modelo proposto é determinista, para se obter um perfil variável de ativação dos canais é necessário adicionar um elemento de variabilidade nas características dos canais. No caso simulado, o atraso de abertura dos canais é agora uma função do número de canais (no caso, de 1 a 5000), dada por: $\tau_{\text {abrindo }}=2+\frac{2}{5} \times$ numCan, em que numCan é o número do canal. Com valores progressivos de $\tau_{\text {abrindo }}$ (o atraso de abertura do canal de sódio) é possível obter o resultado apresentado na figura (4.7).

Ainda com relação ao modelo de Destexhe et al, podem ser utilizadas diversas abordagens para a simulação das cadeias de Markov, como o método por força bruta (que foi o método utilizado para obter a figura (4.6)), que requer a geração de números aleatórios para cada etapa da simulação (isso significa que a cada iteração, o algoritmo de geração 
Figura 4.7: O modelo aproximado proposto, em condições similares a figura (4.6). $\mathrm{Na}$ figura, i significa estado inativado, c significa fechado e o significa aberto.

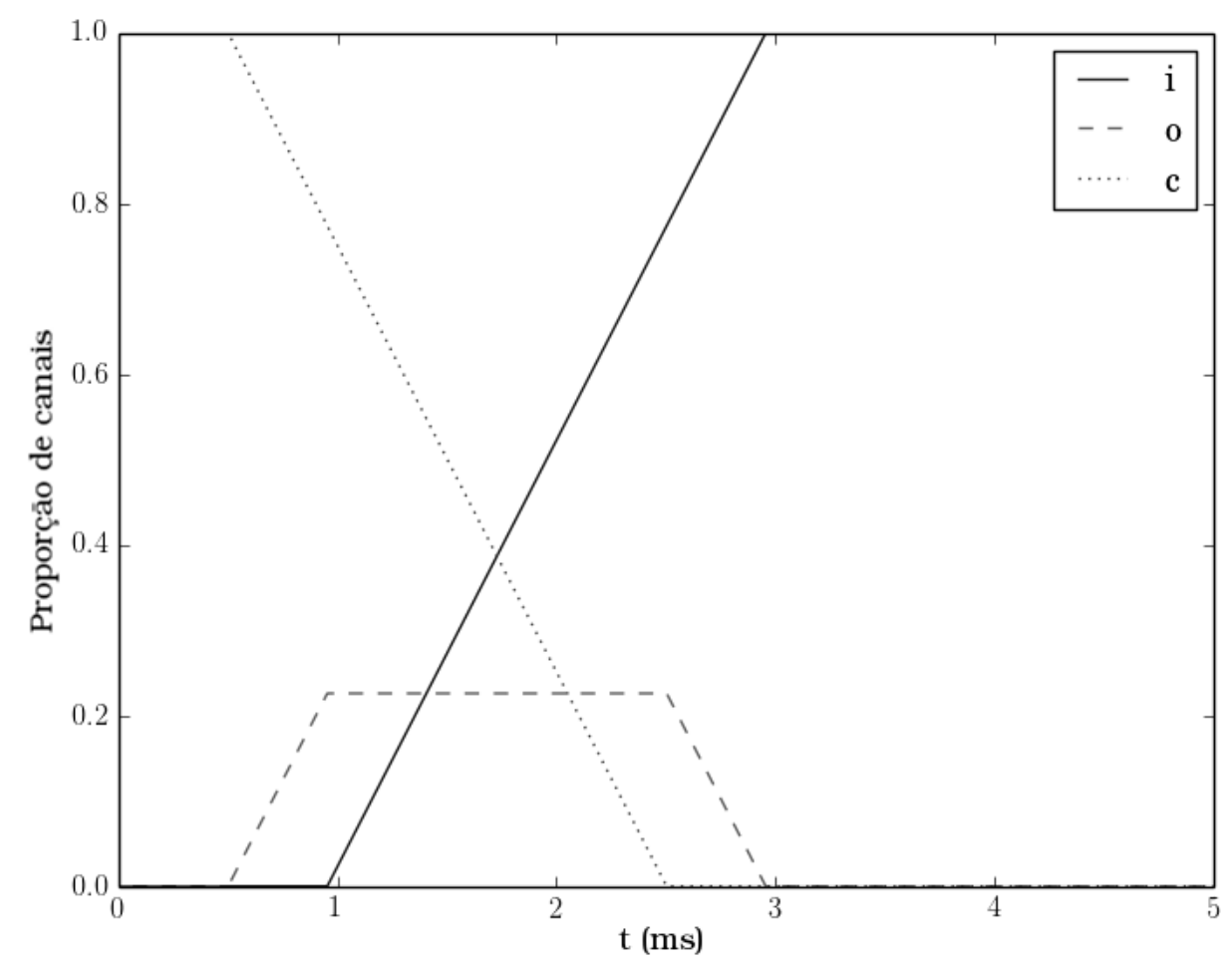

Fonte: Autor.

de números pseudo-aletórios deve sere executado, o que tem um elevado custo computacional). Outros modelos empregam o método de Gillespie (1977), mas nesse caso é necessário algumas simplificações no modelo (como a independência no comportamento dos canais) (SKAUGEN; WALLØE, 1979).

Ainda que o comportamento do modelo apresentado seja mais simples que o do modelo de Destexhe et al, o modelo proposto possui algumas vantagens. Em primeiro lugar, esse modelo não requer a geração de nenhum número aleatório, o que diminui a complexidade computacional (bem como diminui uma provável fonte de discordância com outras simulações, devido a existência de diversos tipos de algoritmos de geração de números aleatórios). As características dos canais devem ser geradas apenas uma vez (na primeira iteração). O programa que implementa o modelo proposto roda em apenas alguns segundos, ao contrário do modelo com cadeias de Markov, que requer alguns minutos para a sua completa execução. 


\subsubsection{Simulações da membrana com todos os canais}

Tendo explorado as características passivas da membrana e o comportamento de um único tipo de canal, o próximo passo é simular o funcionamento da membrana com os dois tipos de canais iônicos sensíveis à tensão, simultaneamente. No modelo proposto foram utilizados canais permeáveis a dois tipos diferentes de íons: sódio e potássio. O efeito desses canais é complementar: enquanto os canais de sódio trabalham para elevar a tensão da membrana, tornando o seu potencial mais positivo, os canais de potássio tem o efeito contrário, fazendo com que a membrana fique com um potencial mais negativo. $O$ potencial de ação, que é essencialmente um pulso de tensão com um pico positivo seguido de uma queda abrupta para um valor bastante negativo, precisa destes dois tipos de canais para a sua simulação.

Na modelagem clássica de Hodgkin e Huxley, existe um repertório relativamente restrito de comportamentos esperados: se for aplicado um estímulo de baixa intensidade, deve ocorrer uma perturbação do potencial de membrana, sem disparo do potencial de ação. Caso o estímulo seja grande o suficiente (acima de um certo limiar) ocorre o disparo do potencial de ação. A frequência dos potenciais de ação é constante para uma dada corrente de entrada, caso essa seja fixa, não ocorrendo alteração do intervalo de disparo (ou seja, sem ocorrer o fenômeno de adaptação).

O objetivo desta simulação é reproduzir esse comportamento. A figura (4.8) é o resultado de uma simulação em que o estímulo é aplicado no início do axônio (as duas primeiras colunas de trechos de membrana), sendo formado por uma sequência de ondas quadradas com saindo da tensão de repouso de membrana de $-65 \mathrm{mV}$ até o valor de $-40 \mathrm{mV}$, com início em $t=9 \mathrm{~ms}$ e término em $t=21 \mathrm{~ms}$, em uma simulação que representa um total de tempo de $30 \mathrm{~ms}$ (ou 30000 iterações), e levou 2 minutos para a execução. A linha contínua representa a tensão no centro do axônio, enquanto a linha pontilhada representa a tensão no início do axônio. Na linha pontilhada ainda é possível observar, ao final do estímulo (por volta de $t=21 \mathrm{~ms}$ ) o disparo de um potencial de ação. Isso ocorre conforme o esperado, porque nessa região também existem canais de sódio e potássio capazes de gerar um potencial de ação. Dessa forma, ao fim do estímulo, quando o trecho inicial de membrana se torna novamente livre para variar o seu potencial (com o fim do estímulo artificial), ocorre um disparo do potencial de ação. Nas condições apresentadas, o período de disparo é de 9,8ms, o que corresponde a uma frequência de $102 \mathrm{~Hz}$.

$\mathrm{Na}$ figura (4.9) pode-se observar em detalhes o potencial de ação gerado pela simulação. $O$ formato é similar ao gerado pelo modelo de Hodgkin e Huxley. 
Figura 4.8: Potencial elétrico da membrana. A linha tracejada representa o potencial elétrico no início do axônio (o estímulo, durante $t=9 \mathrm{~ms}$ até $t=21 \mathrm{~ms}$ ), enquanto a linha contínua representa o potencial elétrico no centro do axônio, em $n_{x}=80, n_{y}=5$. Além disso, $d_{N a}=30$ e $d_{K}=5$.

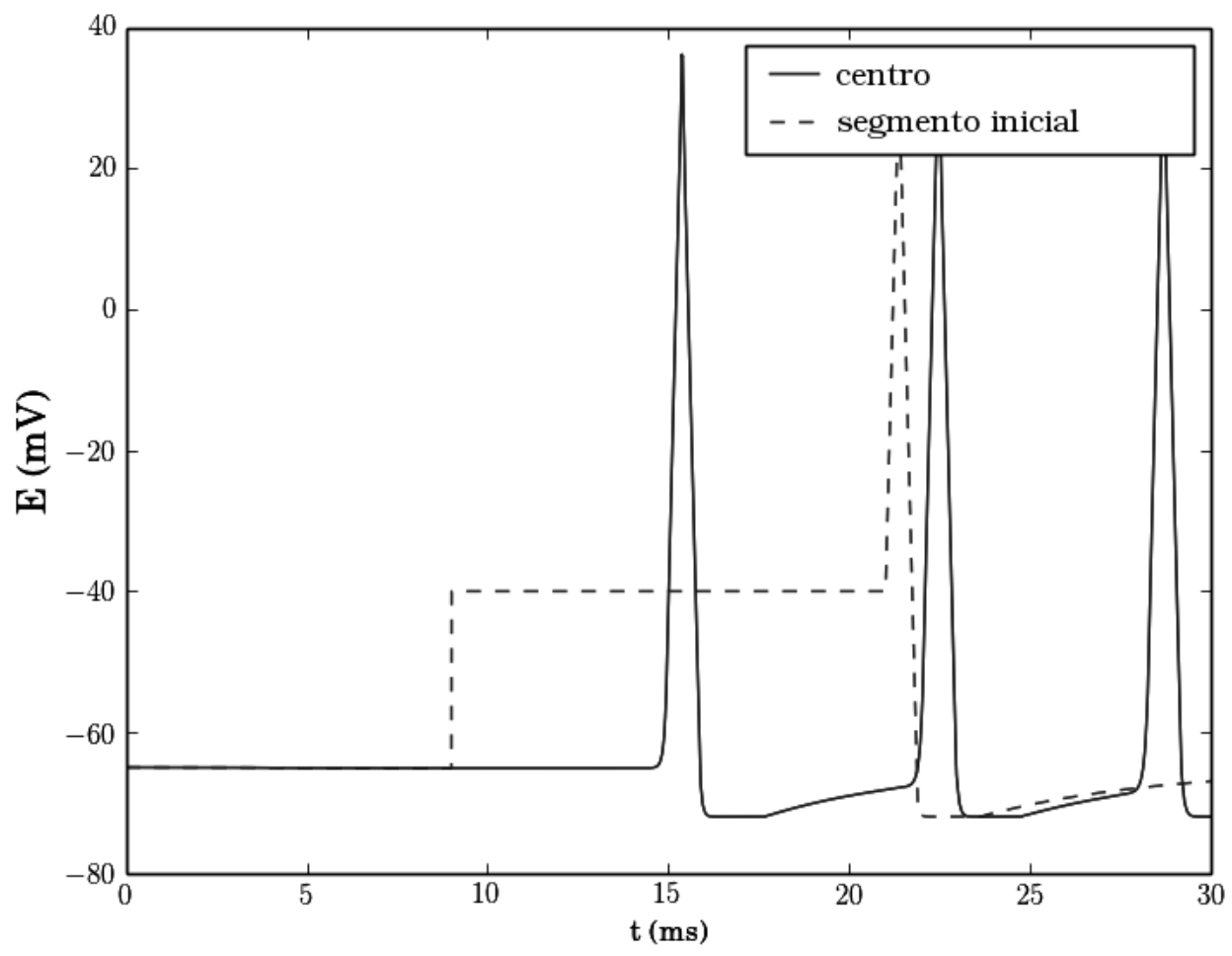

Fonte: Publicado originalmente em (CORREALE; MONTEIRO, 2016). 
Figura 4.9: Detalhe do potencial de ação.

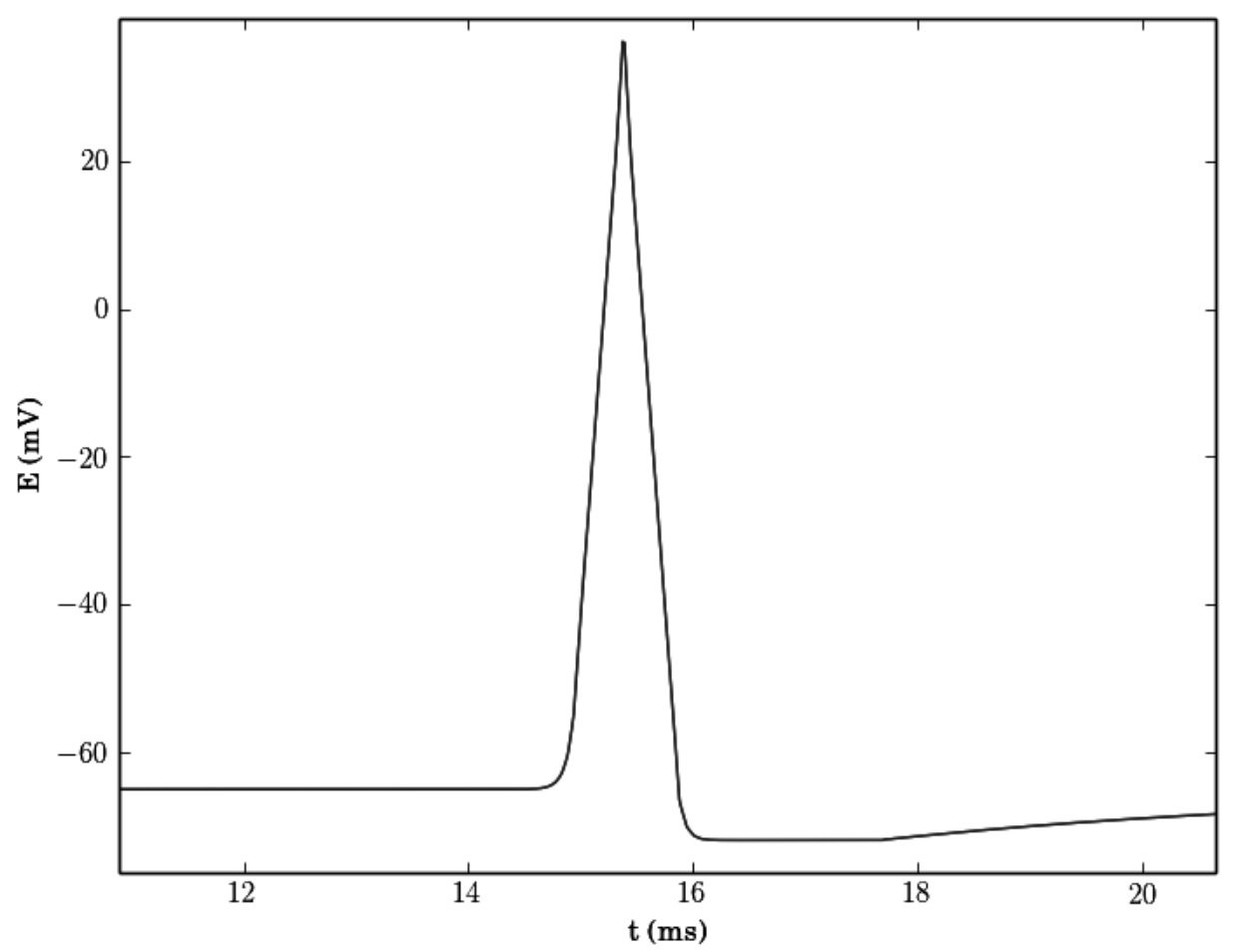

Fonte: Publicado originalmente em (CORREALE; MONTEIRO, 2016). 
Figura 4.10: Gráfico da propagação do potencial ao longo da membrana e do tempo, utilizando os mesmos valores de parâmetros da simulação da figura (4.8).

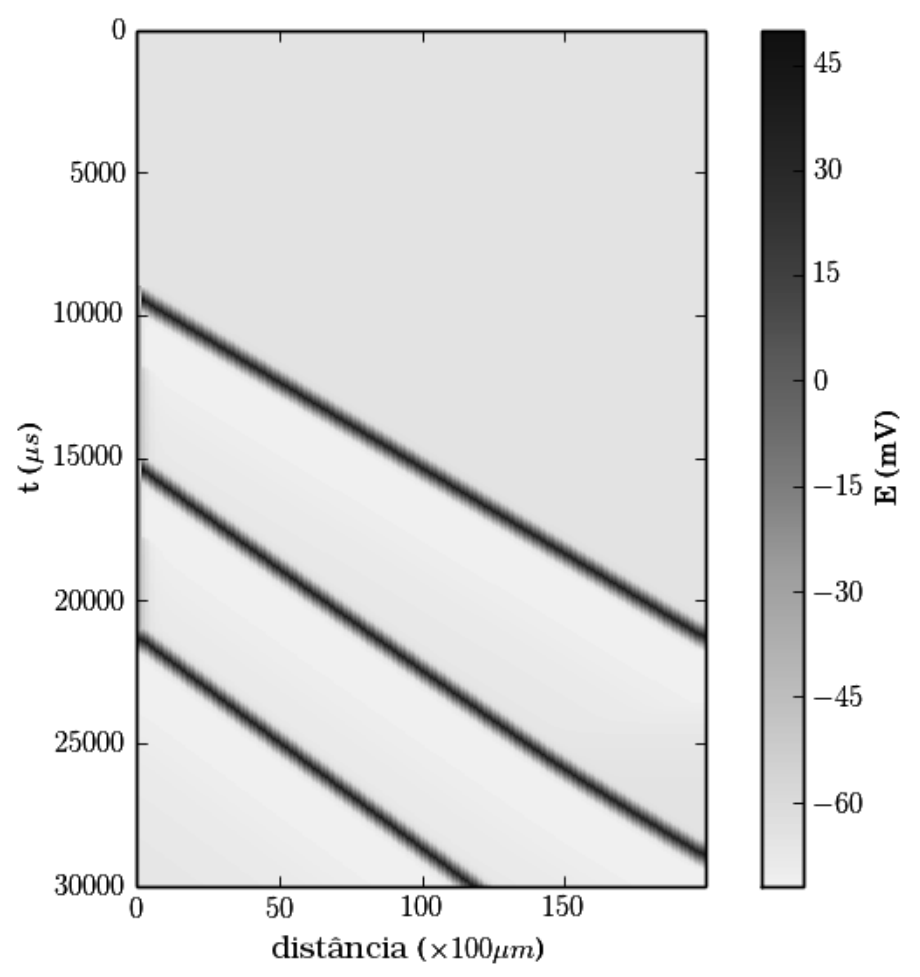

Fonte: Publicado originalmente em (CORREALE; MONTEIRO, 2016).

É possível ilustrar como ocorre a propagação espacial do potencial de ação ao longo do axônio. Devido ao fato do modelo ter uma simetria axial, qualquer linha ao longo do axônio modelado apresenta o mesmo comportamento. Dessa forma é possível gerar um gráfico (ou mapa) em duas dimensões, em que uma das dimensões representa pontos da membrana ao longo do comprimento do axônio, e a outra dimensão representa a passagem do tempo (ou seja, os mesmos pontos físicos da membrana em momentos diferentes). A intensidade da tonalidade de cinza do ponto (do mais claro para o mais escuro) representa a intensidade do potencial de membrana (em $m V$ ). Esse gráfico é mostrado na figura (4.10).

Com o gráfico mostrado na figura (4.10) é possível calcular a velocidade de propagação, e o valor obtido foi de $1,3 \mathrm{~m} / \mathrm{s}$, um valor que é similar ao valor encontrado para pequenos axônios sem a presença de mielina (HILLE, 2001; BEAR et al., 2007).

Finalmente, também é possível observar um retrato do potencial ao longo da membrana em um dado instante, como mostrado na figura (4.11). Nessa figura representa-se o perfil do potencial elétrico da membrana ao longo do axônio. Devido à simetria do problema, o 
Figura 4.11: Potencial elétrico da membrana ao longo do axônio na última iteração. Os parâmetros utilizados são os mesmos da simulação da figura (4.8).

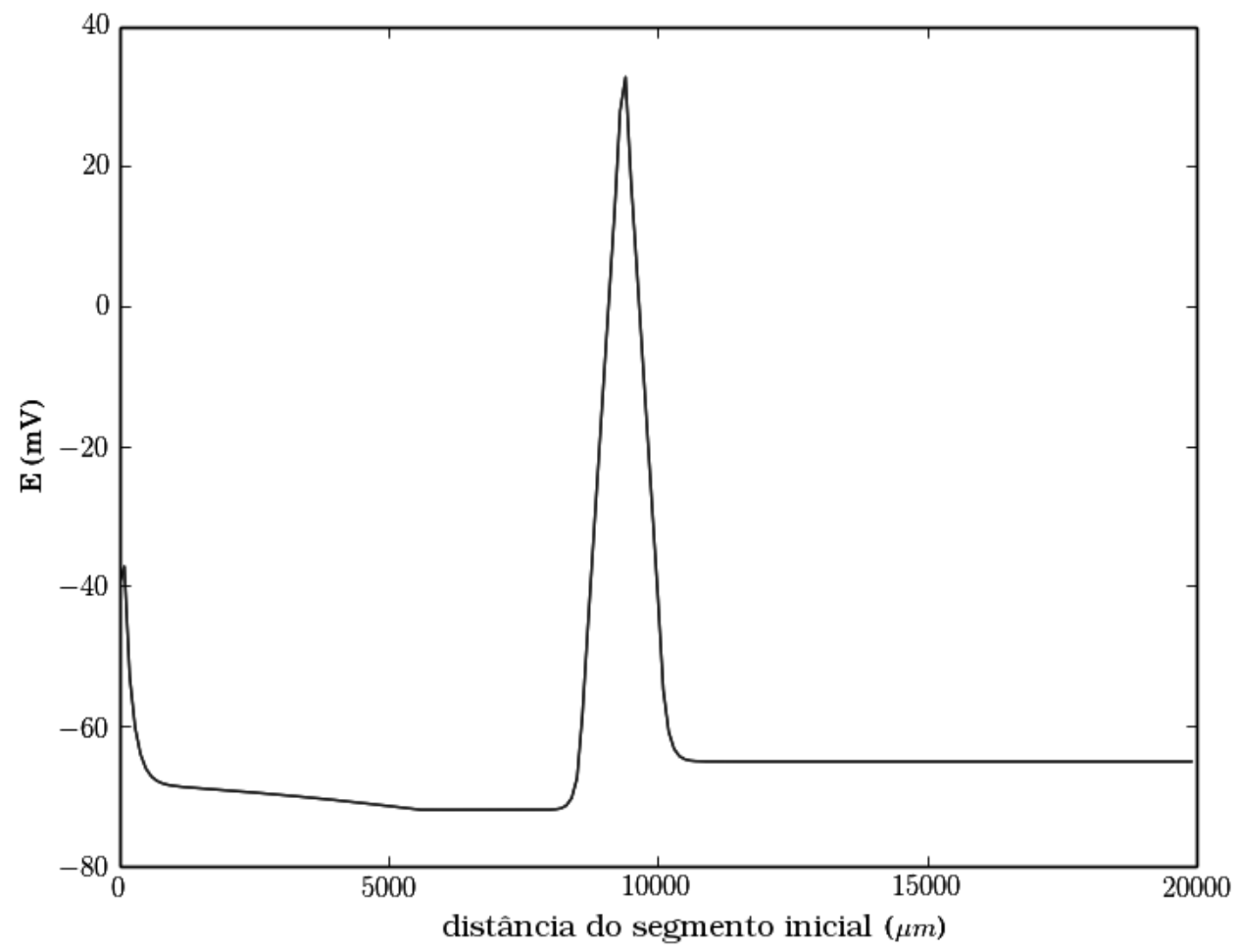

Fonte: Publicado originalmente em (CORREALE; MONTEIRO, 2016).

perfil é o mesmo para qualquer linha do reticulado. O resultado obtido é similar ao modelo estocástico obtido em Neishabouri e Faisal (2014).

Com a incorporação dos canais iônicos, somado aos elementos passivos do modelo, é possível reproduzir a geração de potenciais de membrana gradativos ("graded potentials"): ou seja, a uma resposta tipicamente passiva quando o estímulo é abaixo de um certo valor, ou o disparo do potencial de ação, quando o potencial é maior, como indicado na figura (4.12).

\subsubsection{Incorporando o mecanismo de adaptação}

O fenômeno da adaptação da frequência de disparo do potencial de ação ${ }^{5}$ corresponde à alteração (tipicamente diminuição) da frequência de disparo do potencial de ação ao

5 O nome adaptação possui outros usos na Ciência, podendo gerar, infelizmente, uma certa confusão. Contudo, na área de neurociência, o termo adaptação se tornou comum, e utilizar outra denominação dificultaria a comunicação com outros cientistas da área. 
Figura 4.12: Resposta do modelo em $m V$ (linha contínua) frente a diversas entradas (linha tracejada) com variação da intensidade do potencial (potenciais gradativos).

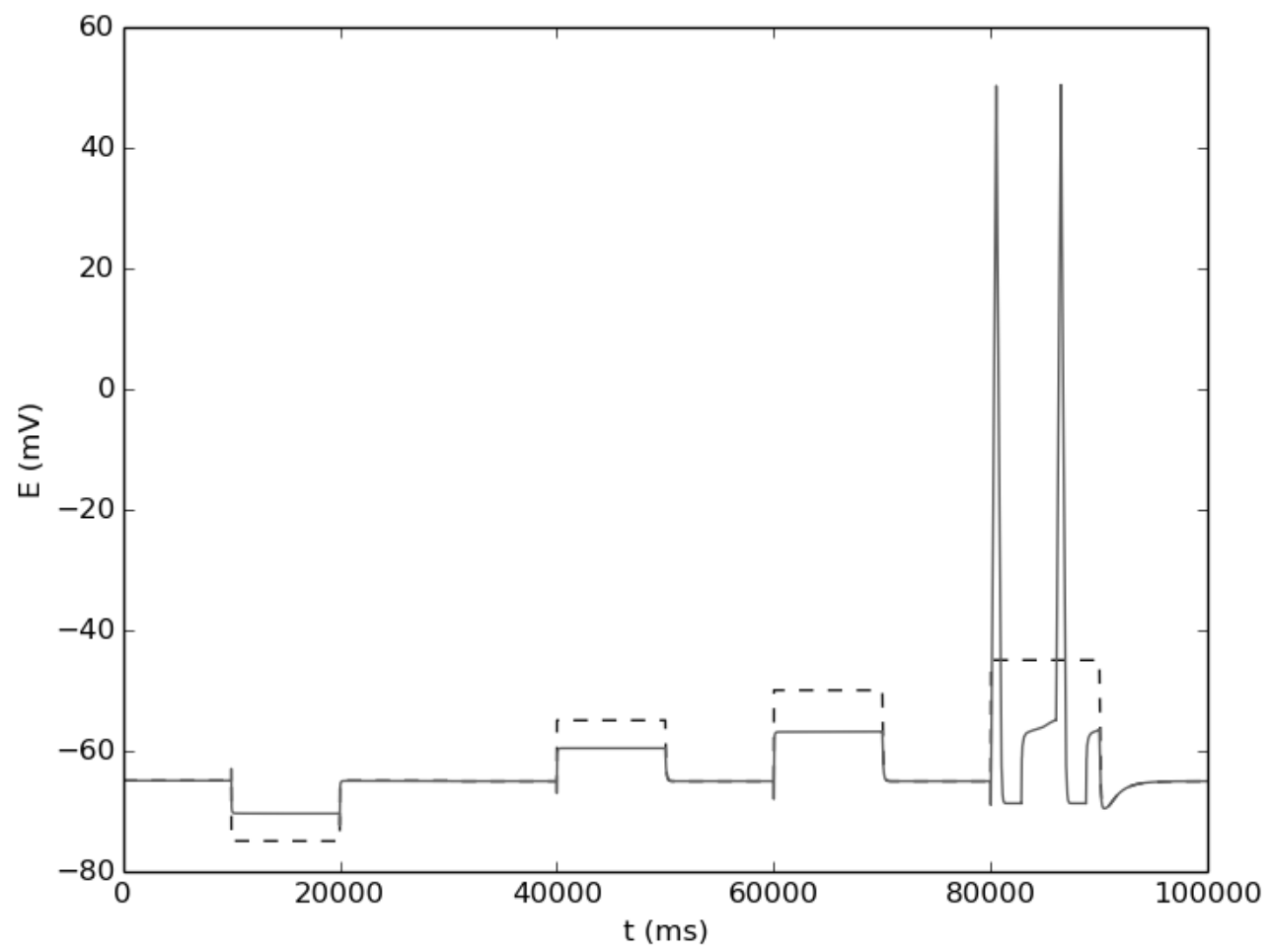

Fonte: Publicado originalmente em (CORREALE; MONTEIRO, 2016).

longo do tempo, para um estímulo com uma intensidade constante (RHOADES; BELL, 2009). O modelo original de Hodgkin e Huxley não possui um mecanismo de adaptação (GREGER; WINDHORST, 2013), o que levou a muitas outras pesquisas posteriores que buscam incorporar esse fenômeno (ERMENTROUT et al., 2001; BENDA; HERZ, 2003) no formalismo original de Hodgkin e Huxley.

A adaptação pode ocorrer em diferentes escalas de tempo, devido a diversos mecanismos (BENDA; HERZ, 2003; LA CAMERA et al., 2006). Um dos mecanismos prováveis é a inativação gradual dos canais de sódio (FLEIDERVISH et al., 1996; DO; BEAN, 2003), resultado de interações moleculares complexas (CHEN et al., 2006; VENKATESAN et al., 2014).

No presente trabalho, para incorporar esse fenômeno, alterou-se o período de inatividade do canal de sódio (FLEIDERVISH et al., 1996; DO; BEAN, 2003). Cada vez que o canal abre (por exemplo, após o disparo de um potencial de ação) aumenta-se a duração 
Figura 4.13: $O$ fenômeno da adaptação no modelo proposto. Para calcular cada um dos pontos, mediu-se a diferença de tempo $\Delta t$ entre o valor máximo de dois potenciais de ação consecutivos(o período), e adotou-se como valor de frequência o inverso desse valor, $f=\frac{1}{\Delta t}$. Além disso, o axônio simulado possui um comprimento de $2000 \mu m$ e perímetro de $500 \mu m$, com $d_{N a}=6$ e $d_{K}=1$.

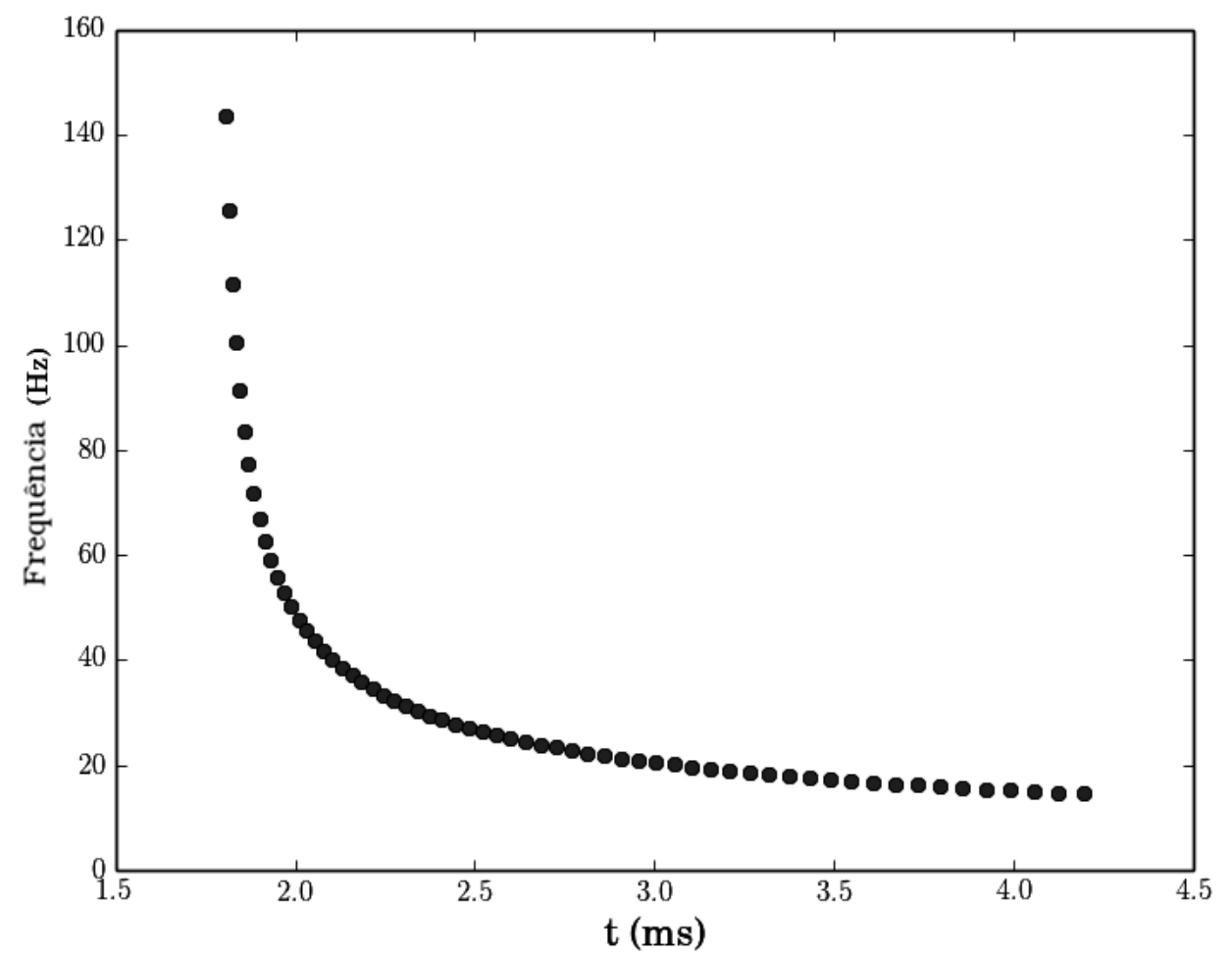

Fonte: Publicado originalmente em (CORREALE; MONTEIRO, 2016).

do período de inatividade, causando um aumento no período do disparo (ou seja, uma diminuição na frequência).

Cada vez que o canal de sódio se abre, adiciona-se $1 \mathrm{~ms}$ ao seu período de inatividade. Ao incorporar adaptação, pode-se gerar um gráfico da variação da frequência de disparo do potencial de ação ao longo do tempo, obtendo a figura (4.13). O estímulo utilizado foi uma onda quadrada com amplitude de $-40 \mathrm{mV}$, iniciando em $1,8 \mathrm{~s}$ com duração até $4,2 \mathrm{~s}$. $\mathrm{O}$ tempo total simulado foi de $6 s$ (ou um total de 6000000 iterações).

Do ponto de vista físico, modelou-se um axônio com $80 \mu \mathrm{m}$ de diâmetro e $2 \mathrm{~mm}$ de comprimento. Utilizou-se uma densidade de 0,0001 canais $/ \mu m^{2}$ de canais de potássio e 0,0006 canais $/ \mu m^{2}$ de sódio. Nessa situação, o tempo de simulação (computacional) foi de 10 minutos. 


\subsubsection{Comparação com dados biológicos}

O objetivo desta seção é mostrar que o ajuste do modelo proposto para simular dados biológicos reais pode ser feito apenas baseado em informações físicas do problema: em vez de otimizar parâmetros de forma "cega" utilizando algum algorítimo automático, os parâmetros foram escolhidos baseando-se nas características do fenômeno sendo modelado.

Nesse ponto, é possível discutir a utilidade de um modelo: um modelo não deve ser apenas um reprodutor automático de resultados, limitando-se a repetir um conjunto de dados (STACHOWIAK, 1973). Se esse fosse o caso, um modelo se tornaria apenas uma espécie de armazenamento compactado de dados. O objetivo do modelo proposto não é de apenas memorizar dados obtidos em laboratório, mas sim buscar uma compreensão mais profunda do fenômeno que está sendo estudado.

Além disso, o modelo proposto busca associar o comportamento dos canais diretamente com a tensão da membrana. Dessa forma, pode-se dizer que o comportamento do neurônio é uma espécie de fenômeno emergente, resultado da interação entre muitos agentes (como os canais e as substâncias ao redor da membrana).

Com o objetivo de verificar a capacidade de ajuste do modelo proposto, foi feita uma comparação dos resultados do modelo com um conjunto de dados obtidos do hipocampo de cobaias de laboratório. Os dados estão publicamente disponíveis no projeto CRCNS: Collaborative Research in Computational Neuroscience (http://crcns.org/). Especificamente, foi utilizado o conjunto de dados hc-2, um conjunto de experimentos nos quais os ratos deviam fazer tarefas em labirintos, em busca de alimento (MIZUSEKI et al., 2009b, 2009a).

Para essa simulação, foram feitas algumas alterações no modelo, com o objetivo de torná-lo ainda mais realista e aderente aos dados de laboratório. Espera-se, em um sistema biológico natural, mesmo canais de um mesmo tipo e em uma mesma membrana possam ter algumas diferenças e imperfeições. A forma como os canais são construídos, a partir de interações químicas complexas, pode levar a pequenas modificações nas características dos canais (OLIVERA et al., 1994; MILLAR et al., 2007).

Para reproduzir o efeito dessas perturbações, alterou-se a forma como alguns parâmetros do modelo são tomados. O intervalo de fechamento para o canal de sódio é agora uma variável aleatória com distribuição uniforme entre $1 \mu$ s e $500 \mu s$. O mesmo foi feito para o canal de potássio, cujo tempo de fechamento também se tornou uma variável aleatória com distribuição de probabilidade uniforme entre $1 \mu \mathrm{s}$ e $15500 \mu \mathrm{s}$. Além disso, o limiar de abertura se tornou uma variável aleatória com distribuição normal, com média $-5 m V$ e desvio padrão de $15 \mathrm{mV}$. 
É importante ressaltar que essas variáveis aleatórias são sorteadas apenas uma vez no início do programa. Uma vez que os seus valores tenham sido obtidos, eles se mantêm constantes durante toda a simulação. Dessa forma, a simulação do funcionamento da membrana continua sendo determinista; apenas os parâmetros iniciais dos canais foram obtidos de forma estocástica.

Diante de uma situação homogênea, em que todos os canais de um mesmo tipo possuem os mesmos parâmetros, não há necessidade de simular muitos canais (por tipo) para cada trecho de membrana (por outro lado, a proporção entre os diversos tipos de canais deve ser mantida, uma vez que o cálculo da tensão se baseia na proporção de canais abertos e fechados). Uma vez que o modelo se baseia em regras deterministas, o comportamento dos canais com parâmetros iguais é o mesmo.

Por outro lado, se há variedade nas características dos canais, é necessário a existência de não apenas um único canal de cada tipo, mas uma distribuição de canais, para evitar conclusões baseadas em artefatos de simulação. Dessa forma, deve-se aumentar a densidade de canais por trecho de membrana. No caso, foram utilizados 1000 canais por trecho de membrana do sódio e 100 canais por trechos de membrana para o potássio (antes, os valores eram 6 canais de sódio e 1 canais de potássio).. A membrana simulada possui $1000 \mu m$ de comprimento total e $500 \mu m$ de largura. $\mathrm{O}$ atraso de abertura continuou sendo um parâmetro fixo, de $2 \mu \mathrm{s}$ para o canal de sódio e $2500 \mu \mathrm{s}$ para o canal de potássio. A simulação representa $12,5 \mathrm{~ms}$ (12500 iterações), levando por volta de 1 minuto para a sua execução. Os demais parâmetros permaneceram iguais. O resultado é apresentado na figura (4.14). 
Figura 4.14: Comparação entre o modelo (linha tracejada) e dados gravados do hipocampo de ratos (linha contínua).

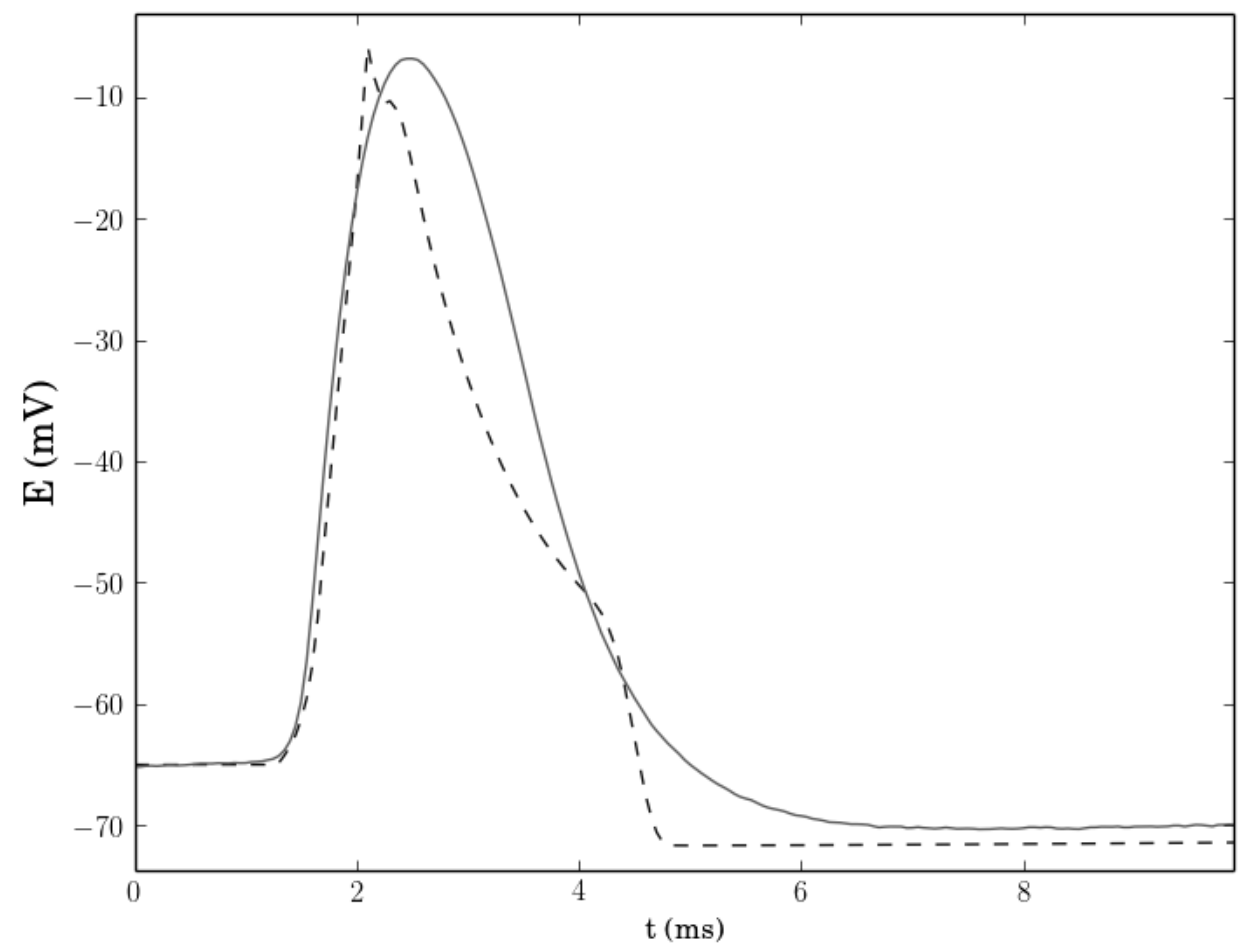

Fonte: Publicado originalmente em (CORREALE; MONTEIRO, 2016). 


\subsection{A curva fl}

Outro aspecto relevante na caracterização de um neurônio é a sua curva fl de frequência $(f)$ versus corrente de entrada $(I)$. Ela pode ser levantada experimentalmente por meio da injeção de uma corrente de valor constante em um ponto do neurônio, e observando a oscilação da tensão da membrana (se houver) para diversos valores de corrente de entrada. Na figura (4.15) apresenta-se um exemplo de curva fl para o neurônio de um gato, retirado de Ermentrout (1998).

Figura 4.15: Frequência de um neurônio de gato em função de um pulso de corrente de entrada. Os pontos foram ajustados por uma curva quadrática.

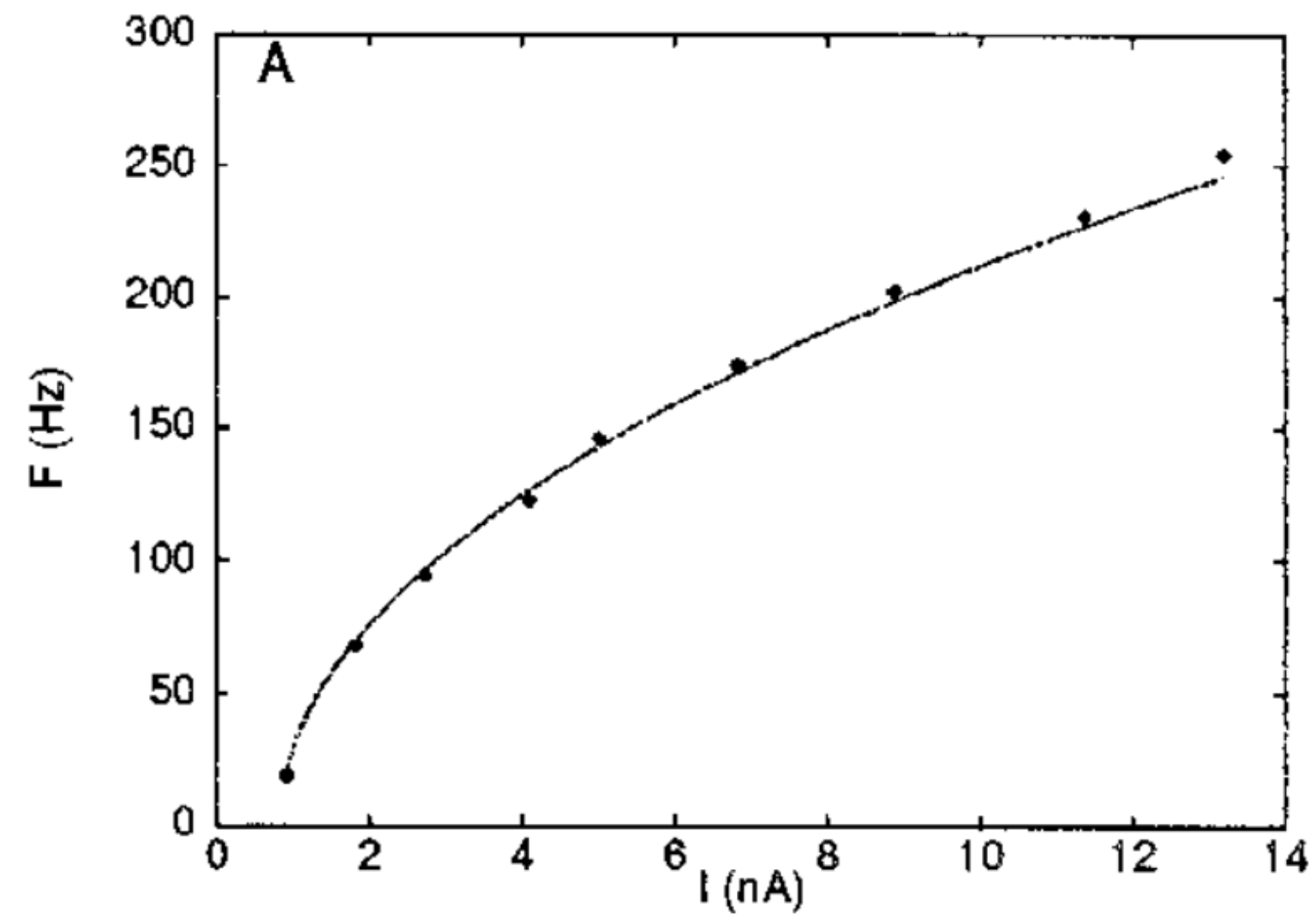

Fonte: Retirado de (ERMENTROUT, 1998) com dados de (STAFSTROM et al., 1984).

A dinâmica dos neurônios pode ser dividida em dois tipos: tipo-I e tipo-II. Neurônios do tipo-I possuem uma curva fl que é contínua, ou seja, iniciam a sua oscilação em frequências baixas tendo um aumento gradual de frequência conforme se aumenta o valor da corrente de entrada. 
Por outro lado, neurônios do tipo-Il possuem uma curva fl descontínua: eles saem do estado quiescente e vão direto para o estado oscilatório, iniciando a oscilação a partir de uma frequência elevada, havendo um "salto" na sua curva fl. O modelo clássico de Hodgkin e Huxley é to tipo-II, tendo uma frequência inicial de oscilação bastante elevada (por volta algumas dezenas de hertz) (GERSTNER et al., 2014). Na figura (4.16) é possível observar um desenho esquemático que representa a curva fl para esses dois tipos de neurônios.

Figura 4.16: Curvas fl para os neurônios dos tipos I e II.

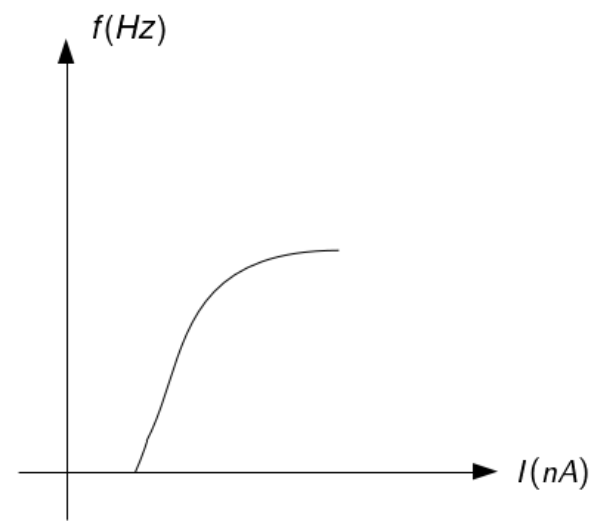

Neurônio Tipo-I

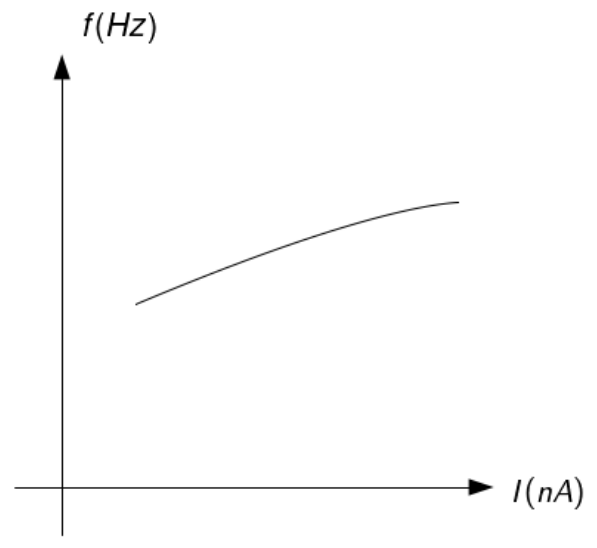

Neurônio Tipo-II

Fonte: Adaptado de Gerstner et al. (2014).

É possível entender essas curvas do ponto de vista de sistemas dinâmicos, especialmente utilizando a teoria de bifurcações. Nesse caso, deve-se analisar o comportamento do sistema com relação à variação de algum parâmetro, observando-se as variações qualitativas do sistema. No caso dos neurônios, costumam-se caracterizá-los pelo comportamento da curva de corrente versus frequência de oscilação (a curva fl).

Ao se analisar a dinâmica dos principais modelos de neurônio de um ponto de vista da teoria das bifurcações, é possível observar bifurcações de Hopf, sela-nó envolvendo ciclo limite(GUCKENHEIMER; LABOURIAU, 1993; IZHIKEVICH, 2007; GERSTNER et al., 2014; DRION et al., 2015; ZEBERG et al., 2015; CORREALE; MONTEIRO, 2017).

Em vez da frequência entre disparos, algumas vezes é analisado o período, sendo obtida uma curva da corrente elétrica de entrada versus o intervalo entre disparos (no inglês inter-spike interval, ou ISI). Na figura (4.17) compara-se o intervalo entre disparos do modelo proposto de neurônio (tipo-II) com o modelo de Hodgkin e Huxley (também do tipo-II). 
Figura 4.17: Comparação do intervalo entre disparos para o modelo proposto de neurônio e o modelo de Hodgkin e Huxley.

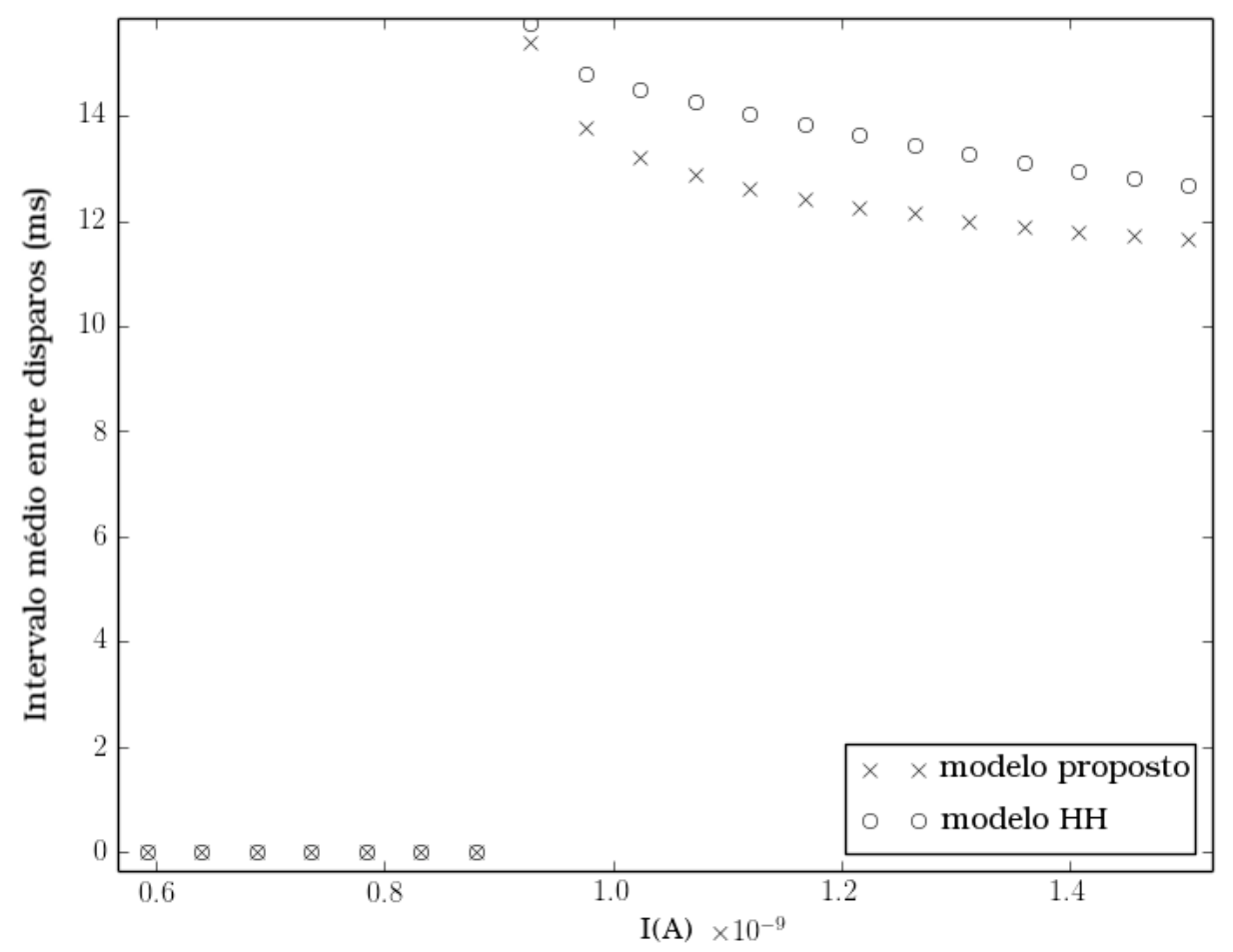

Fonte: Autor.

Observe que ambas as curvas possuem um formato no qual, conforme a corrente de entrada aumenta, o intervalo entre disparos diminui. Isso corresponde ao aumento da frequência de disparos gerada pelo aumento da corrente de entrada. A fim de que o modelo proposto se comporte de forma similar ao modelo de Hodgkin e Huxley, como mostrado na figura (4.17), foi feita uma mudança: o tempo de inativação do canal de sódio $\tau_{\text {NaInativado }}$ sofreu uma alteração na forma de cálculo. Nessa simulação, a cada iteração, o valor de $\tau_{\text {NaInativado }}$ é calculado de acordo com a equação (4.11):

$$
\tau_{\text {NaInativado }}[t+1]=\tau_{\text {NaInativado }}[t]-\delta_{\text {NaInativado }}[t]
$$

com $\delta_{\text {NaInativado }}[t]$ sendo obtido pela equação (4.12):

$$
\delta_{\text {NaInativado }}[t]=\operatorname{int}\left(\frac{E_{\text {memb }}[t]+66.0}{20.0}\right)
$$


Na equação (4.12) a função int retorna a parte inteira do seu argumento, funcionando como um arredondamento para o número inteiro inferior. $O$ valor máximo de $\delta_{\text {NaInativado }}[t]$ também é limitado (em 25), e o valor de $\tau_{\text {NaInativado }}[t]$ tem um limite inferior de $2000 \mathrm{~ms}$. Isso foi feito com o objetivo de se obter uma frequência máxima, uma vez que um neurônio biológico real possui um limite máximo de oscilação, limitado pelas suas características físico-biológicas. Dessa forma, foi possível reproduzir não apenas o formato geral da curva $\mathrm{fl}$, mas também os valores específicos, que podem ser ajustados alterando-se os valores dos parâmetros do modelo proposto.

\subsubsection{Mudando o tipo de neurônio}

Nas condições previamente apresentadas, o modelo simulado é do tipo-II. Nessa seção avalia-se como é possível mudar o modelo do neurônio para o tipo-I.

Uma das hipóteses para a variação dos tipos de neurônios está ligada a variação nas características dos canais iônicos. No artigo de (DRION et al., 2015), discutem-se algumas formas pelas quais neurônios podem ser do tipo-I ou do tipo-II. Em modelos puramente matemáticos, a mudança do tipo-Il para tipo-l é feita adicionando-se uma condutância adicional referente ao íon de potássio, muitas vezes chamadas de condutância de inativação.

Contudo, esse mesmo artigo explora uma outra possibilidade: a chamada "degeneração", ou seja, a possibilidade de múltiplas correntes devido à existência de canais com características variadas, mas de um mesmo tipo de ín (isso ocorre provavelmente devido a pequenas alterações na forma como os canais são construídos)(DRION et al., 2015).

Para transformar o modelo proposto de tipo-II para tipo-I, foi utilizada uma abordagem em alguns aspectos similar a do artigo de Drion et al. (2015). Foi criado um conjunto de canais de potássio com características similares aos utilizados nas outras simulações, exceto com relação ao tempo de abertura, que em vez de ser um valor fixo $(2500 \mu \mathrm{s})$ agora varia de forma linear. Dessa forma, em vez de termos um único valor para todos os canais de potássio, tem-se um conjunto de canais com valores de tempo de abertura variando de zero até $210000 \mu \mathrm{s}$ (em intervalos de $14000 \mu \mathrm{s}$ ). Dessa forma, cada trecho de membrana tem agora 15 canais de potássio, cada um com um valor de tempo de abertura ligeiramente diferente do outro.

Devido ao aumento do número de canais de potássio, e para manter a proporção de um canal de potássio para seis canais de sódio, o número total de canais de sódio por trecho de membrana subiu para 90. Com essas modificações, foi possível obter a resposta em frequência mostrada na figura (4.18). 
Figura 4.18: Frequência de disparos do potencial de ação para o modelo modificado. Observe que para baixas correntes de entrada a frequência de disparo é pequena, subindo de forma gradual até chegar um valor máximo, o comportamento característico dos neurônios tipo-I.

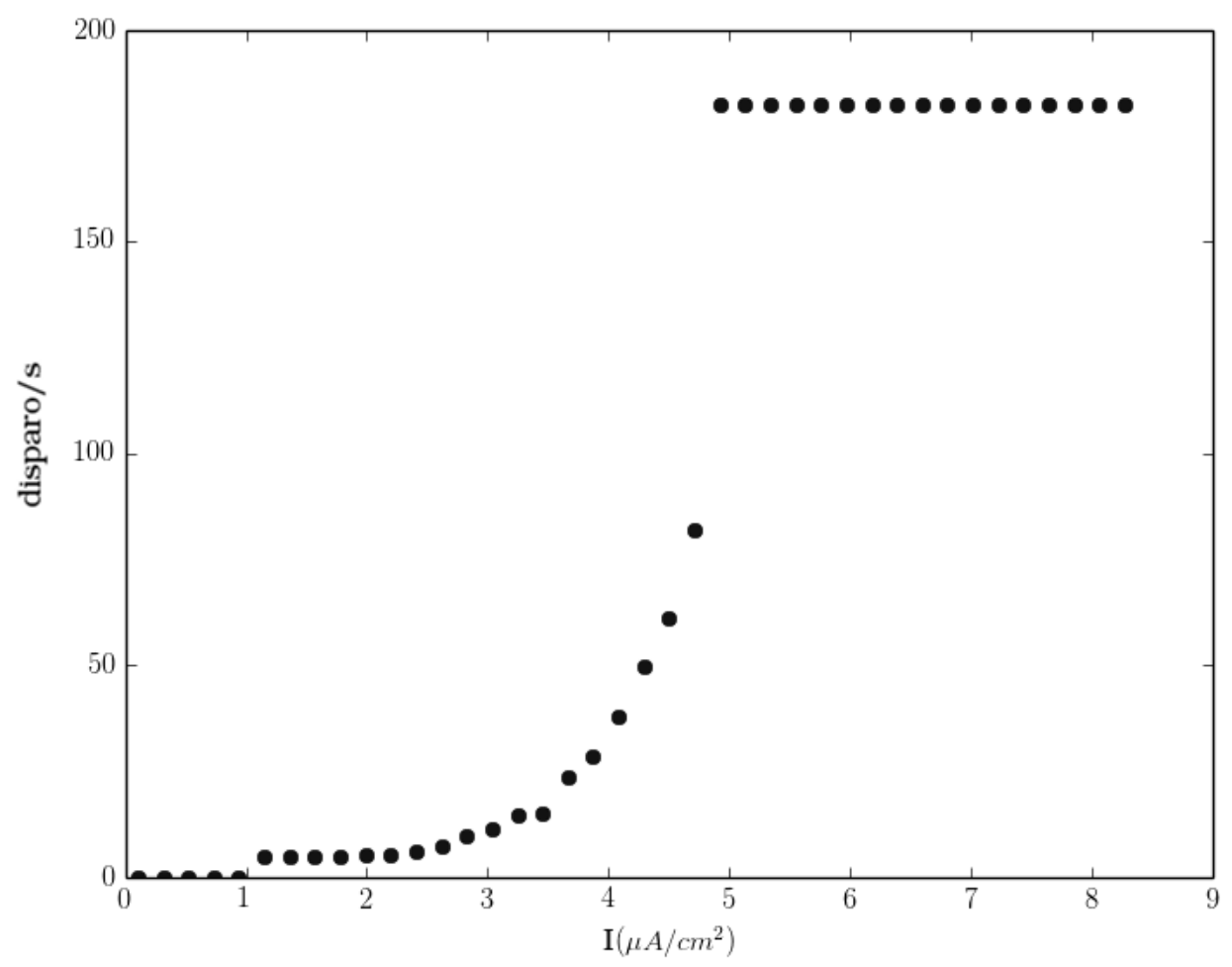

Fonte: Autor.

\subsubsection{Simplificando o modelo}

Um segundo artigo foi publicado, explorando o modelo proposto. Nesse artigo (CORREALE; MONTEIRO, 2017) foi utilizado um reticulado menor, com 25 quadrados em uma estrutura de $5 \times 5$ (sendo que cada quadrado do reticulado continua tendo a mesma dimensão de $100 \mu m \times 100 \mu m$ ), um comprimento de $500 \mu m$ e um diâmetro de $160 \mu m$. Neste novo modelo, a corrente de entrada foi aplicada no primeiro quadrado do reticulado - com posição $(1,1)$ - e o valor do potencial de membrana $E[t]$ foi calculado na posição central do axônio, de coordanadas $(3,3)$.

O objetivo dessa nova simulação é similar ao anterior, ou seja, partindo de um modelo do tipo II, fazer modificações que levem esse modelo se comportar como um neurônio do tipo I. Contudo, buscou-se também fazer uma simplificação do modelo, com o objetivo de identificar um conjunto mínimo de mudanças entre um neurônio do tipo I e do tipo II. 
Assim, para simular um neurônio do tipo-Il foram utilizados os parâmetros especificados na tabela (4.4). Com esses parâmetros, não foi necessário utilizar a equação (4.12).

Tabela 4.4: Parâmetros utilizados para a simulação da figura $(4.19)$
\begin{tabular}{|c|c|}
\hline Parâmetro & Valor \\
\hline$E_{N a}$ & $50 \mathrm{mV}$ \\
\hline$E_{\text {NaLimAbert }}$ & $-55 \mathrm{mV}$ \\
\hline$\tau_{\text {NaAbrindo }}$ & $20 \mu \mathrm{s}$ \\
\hline$\tau_{\text {NaAberto }}$ & $450 \mu \mathrm{s}$ \\
\hline$\tau_{\text {NaInativado }}$ & $5000 \mu \mathrm{s}$ \\
\hline$E_{K}$ & 6 \\
\hline número de canais de sódio por quadrado $d_{N a}$ & $-72 \mathrm{mV}$ \\
\hline$E_{\text {KLimAbert }}$ & $-5 \mathrm{mV}$ \\
\hline$\tau_{K \text { Abrindo }}$ & $2 \mu \mathrm{s}$ \\
\hline$\tau_{K A b e r t o}$ & $10000 \mu \mathrm{s}$ \\
\hline$C_{m}$ & 1 \\
\hline número de canais de potássio por quadrado $d_{K}$ & $1 \mu \mathrm{F} / \mathrm{cm}^{2}$ \\
\hline
\end{tabular}

Fonte: Autor.

Utilizando os parâmetros listados na tabela (4.4), e considerando uma corrente de entrada fixa de aproximadamente $I=3 \times 10^{-10} \mathrm{~A} / \mathrm{cm}^{2}$, obtêm-se as formas de onda ilustradas na figura (4.19). Para o modelo de Hodgkin e Huxley foram utilizados os seguintes parâmetros: $C_{m}=1 \mu \mathrm{F} / \mathrm{cm}^{2}, \bar{g}_{N a}=120 \mathrm{mS} / \mathrm{cm}^{2}, E_{N a}=50 \mathrm{mV}, \bar{k}_{K}=36 \mathrm{mS} / \mathrm{cm}^{2}$, $E_{K}=-77 \mathrm{mV}, \bar{g}_{\text {leak }}=0,3 \mathrm{mS} / \mathrm{cm}^{2}, E_{\text {leak }}=-54,4 \mathrm{mV}$. Além disso, as condições iniciais foram $E(0)=-65 m V, m(0)=0, h(0)=0$ e $n(0)=0$. As equações foram integradas utilizando o método de Adams.

É possível observar na figura (4.19) que ambas as formas de onda tem aproximadamente a mesma frequência (no caso, de aproximadamente $97 \mathrm{~Hz}$ ), e uma pequena diferença de fase. As duas formas de onda são similares.

Se compararmos a evolução da frequência de oscilação versus a corrente de entrada para ambos os modelos (o modelo proposto nessa seção e o modelo de Hodgkin e Huxley), obtém-se o gráfico da figura (4.20).

$\mathrm{Na}$ figura (4.20) é possível perceber que ambos os modelos possuem uma curva fl similar do tipo-II. A descontinuidade ocorre em ambos os modelos aproximadamente para a mesma corrente de entrada $\left(100 \mathrm{pA} / \mathrm{cm}^{2}\right)$.

É possível observar que nessa versão do modelo a curva fl é mais plana que no modelo anterior, em que se utiliza a equação (4.12) para controlar a variação da resposta em frequência. Seria possível aumentar ainda mais o grau de aderência das duas curvas fl 
Figura 4.19: Comparação dos disparos de potencial de ação no modelo proposto no presente trabalho (linha grossa) e o modelo de Hodgkin e Huxley (linha fina).

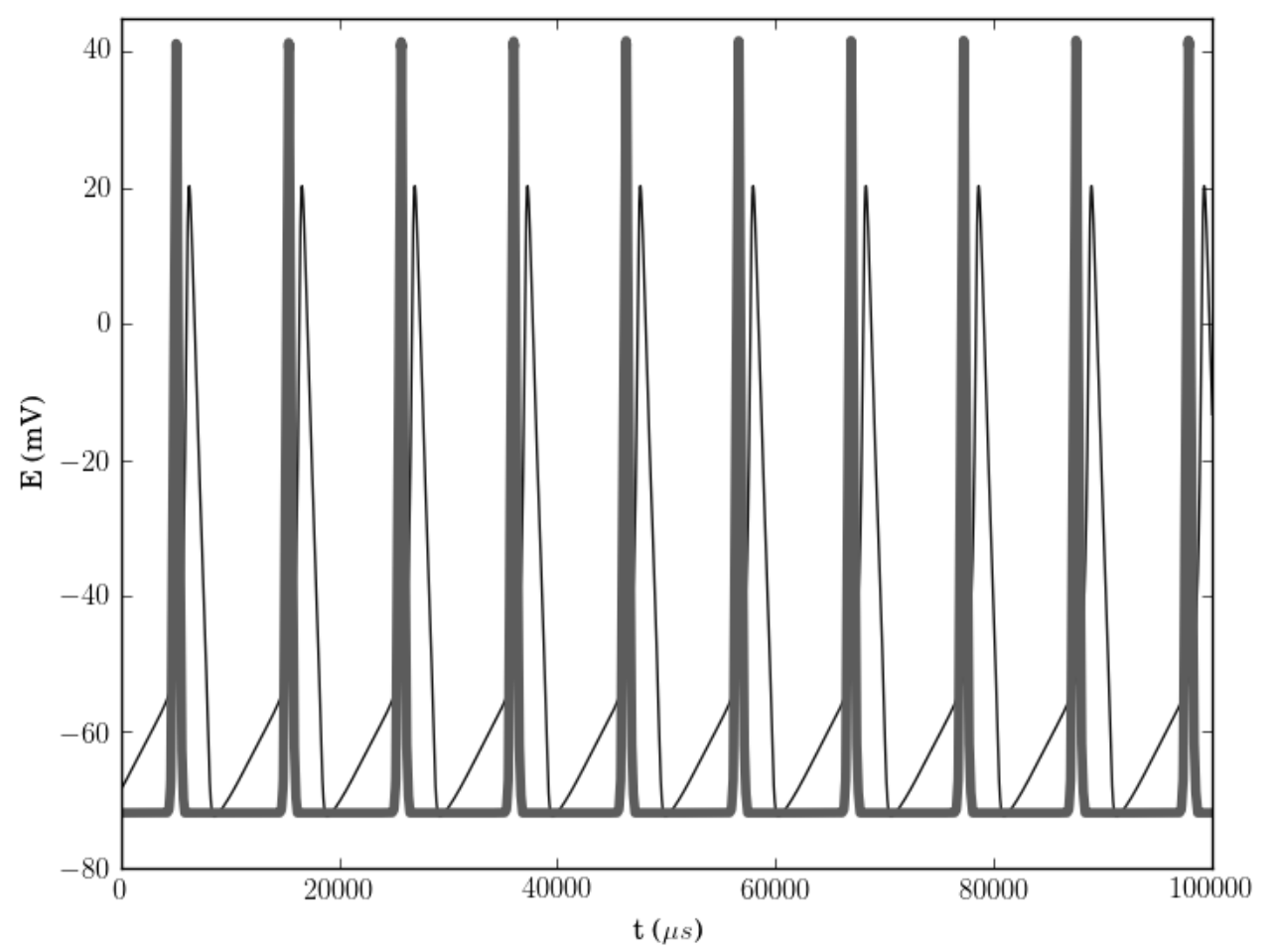

Fonte: Autor.

mostradas na figura (4.20) utilizando uma equação similar a equação (4.12). Contudo, eliminado-se essa equação é possível obter um modelo mais simples.

Para modificar o neurônio do tipo-Il para o tipo-I, foram feitas três modificações no modelo proposto inicialmente (CORREALE; MONTEIRO, 2017):

1. criou-se uma distribuição $0^{6}$ de valores para $\tau_{\text {KAberto }}$, variando igualmente entre $25000 \mu \mathrm{s}$ e $40000 \mu \mathrm{s}$, em vez de um valor igual e constante de $10000 \mu \mathrm{s}$ para todos os canais de potássio. De acordo com Drion et al. (2015), uma forma de transformar um canal do tipo-ll para o tipo-l é por meio da chamada "degeneração dos canais iônicos", ou seja, canais iônicos de um mesmo tipo, mas que possuem características diferentes (DRION et al., 2015; CORREALE; MONTEIRO, 2017);

6 Aqui, a palavra distribuição denota a ideia de distribuição de valores, e não do conceito estatístico de distribuição de probabilidades. O modelo continua sendo determinista. 
Figura 4.20: Curvas fl obtidas com o modelo proposto (representado por $\times$ ) e com o modelo de Hodgkin e Huxley (representado por $\bullet$ ).

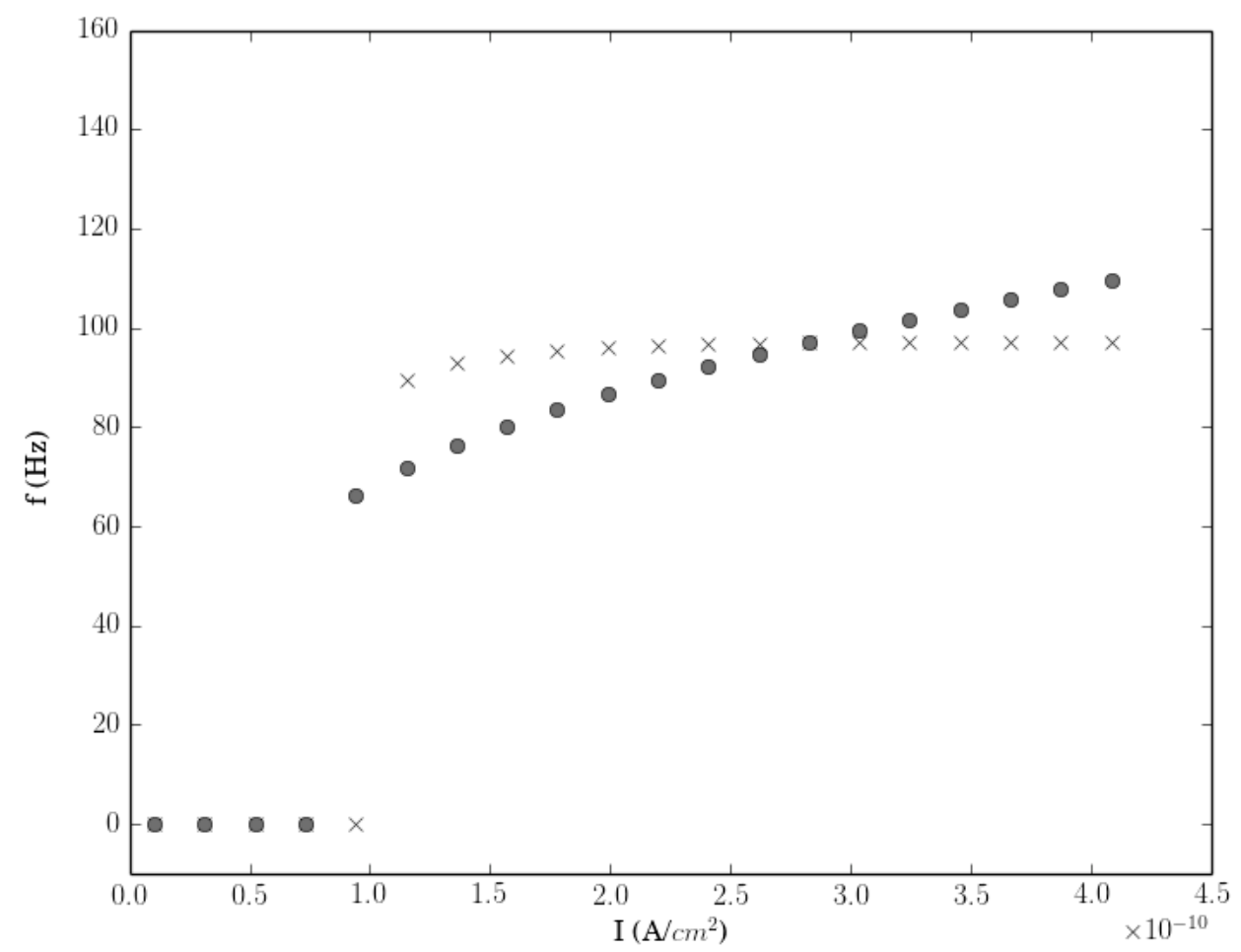

Fonte: Publicado originalmente em (CORREALE; MONTEIRO, 2017). 
Figura 4.21: Curvas fl obtida com a modificação do modelo proposto, de tipo-Il para tipo-I. Foi mantida a mesma escala vertical da figura (4.20) para facilitar a comparação.

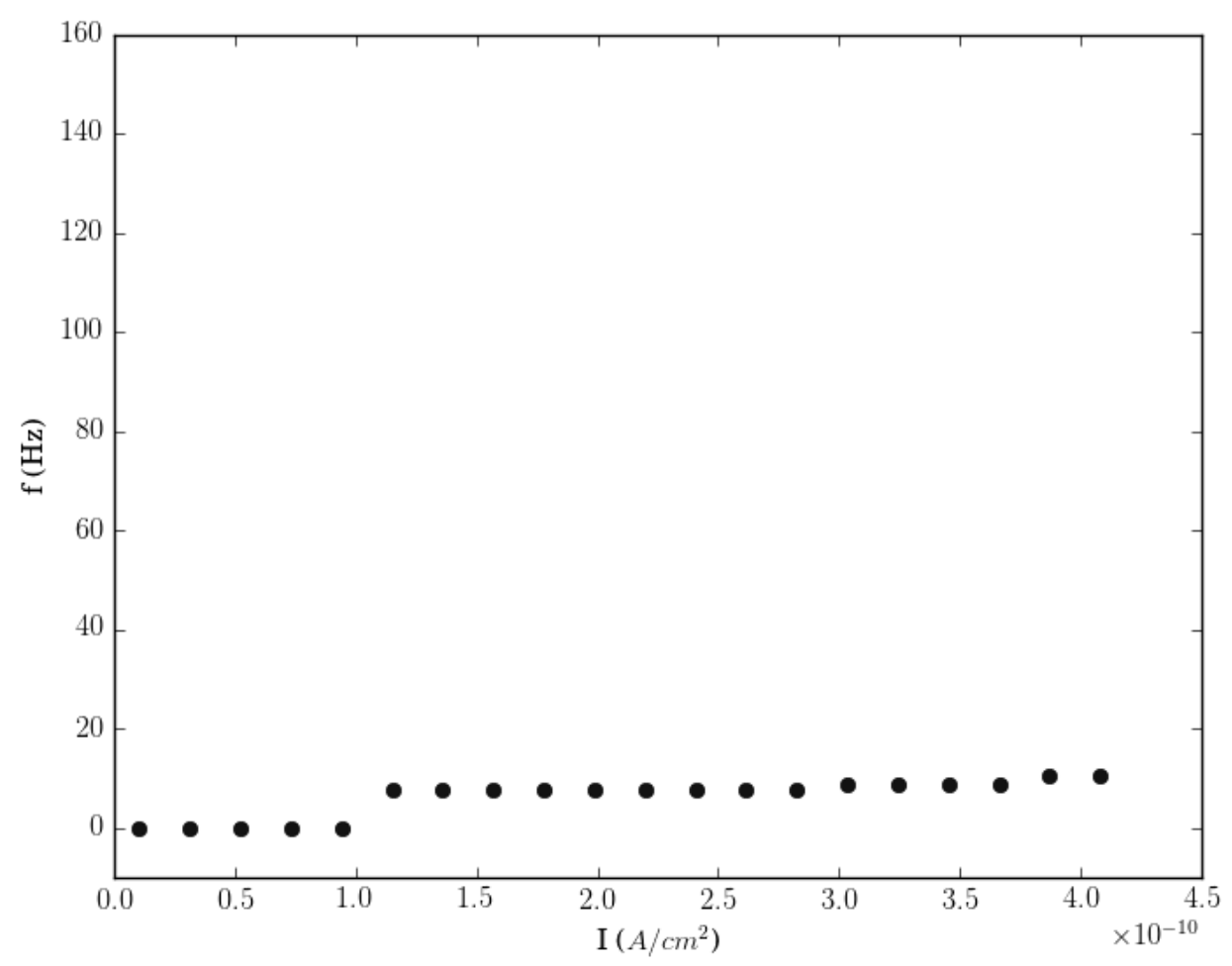

Fonte: Publicado originalmente em (CORREALE; MONTEIRO, 2017).

2. para criar uma variabilidade nos canais de um mesmo tipo, foi necessário aumentar a quantidade total de canais. No caso do potássio, a densidade de canais de íons de potássio por quadrado $d_{K}$ foi ampliada de 1 para 6 ;

3. a proporção de canais de íons $d_{K} / d_{N a}$ foi ampliada de $1 / 6$ para $1 / 3$, como indicado por alguns experimentos (ZEBERG et al., 2015).

Com essas três modificações, foi obtida a curva $f$ indicada na figura (4.21). Observe que a frequência inicial de disparo é muito menor que no gráfico anterior e permanece aproximadamente constante nesse valor.

Seria possível criticar esses resultados argumentando que continua ocorrendo um salto na frequência inicial. Contudo, é importante observar que qualquer modelo essencialmente discreto, ou que execute em um computador digital, sempre vai ter um salto na frequência, devido à natureza inerentemente descontínua do modelo. O que foi feito foi mostrar que é possível diminuir a frequência inicial de disparo para um valor arbitrariamente pequeno 
(no caso, de apenas alguns hertz, em vez de uma centena de hertz) modificando-se três características do modelo original. Além disso, essas modificações são coerentes com a estrutura física do fenômeno sendo estudado (como indicado no artigo de Zeberg et al. (2015)), e não apenas alterações matemáticas sem fundamento biológico. 


\section{Capítulo 5}

\section{O modelo da sinapse}

A significant idea of organization cannot be obtained in a world in which everything is necessary and nothing is contingent.

Norbert Wiener

Neste capítulo descreve-se a extensão do modelo previamente apresentado, incorporando o modelo de uma sinapse química. Em seres humanos, estima-se que existam 20 bilhões de neurônios, e que em média existam 7000 sinapses em cada um desses neurônios (DRACHMAN, 2005). Considerando apenas o neocórtex, estima-se uma quantidade de 0,15 quadrilhões de sinapses $\left(0,15 \times 10^{15}\right)$ (PAKKENBERG et al., 2003).

Existem fortes evidencias de que as sinapses possuam uma capacidade computacional intrínseca (ABBOTT; REGEHR, 2004; SOLTANI; WANG, 2010; PELAEZ; ANDINA, 2013). Se esse for o caso, é fundamental identificar os aspectos computacionais das sinapses e buscar compreender o seu funcionamento.

Em muitos modelos computacionais de redes neurais, como o modelo inicial de McCulloch e Pitts (1943) ou nas redes neurais do tipo Perceptron (ROSENBLATT, 1957), os modelos das sinapses são bastantes simples, correspondendo a uma operação numérica de multiplicação, adição ou contagem. O neurônio em si é representado por uma função de ativação do tipo degrau (ROJAS, 2013; HAYKIN, 2011). Dependendo do grau de detaIhe desejado, esses modelos podem ser insuficientes. Deve-se ter em mente que, de um ponto de vista biológico, as sinapses químicas são fenômenos extremamente complexos.

O modelo aqui proposto corresponde ao de uma sinapse química, que é a mais comum no cérebro humano (BEAR et al., 2007; STERRATT et al., 2011; KANDEL et al., 2012). Contudo, além das sinapses químicas, existem também as chamadas sinapses elétricas, 
que permitem a passagem direta de certas substâncias químicas entre neurônios e potencialmente auxiliam na sincronia entre algumas áreas do cérebro (uma vez que essas sinapses tendem a ser mais rápidas) (BENNETT; ZUKIN, 2004; BEAR et al., 2007; STERRATT et al., 2011).

\subsection{A construção de um modelo de sinapse}

Para construir o modelo de uma sinapse química, ao menos três elementos devem ser incorporados:

- O lado pré-sináptico, que corresponde ao ponto do neurônio que recebe a informação do potencial de ação, contém a zona ativa, permite a passagem controlada dos íons de cálcio de acordo com a tensão da membrana e libera neurotransmissores. Essa região também costuma ser chamada de botão sinápico (PATRICK, 2013);

- a fenda sináptica, onde os neurotransmissores são liberados e devem se difundir para influenciar o neurônio seguinte (no lado pós-sináptico);

- o lado pós-sináptico do neurônio (frequentemente localizado em um dendrito), onde canais sensíveis aos neurotransmissores vão permitir a entrada seletiva de íons na célula.

Existem muitas formas diferentes de sinapses e diferentes esquemas de classificação. Por exemplo, do ponto de vista fisiológico, sinapses podem ser classificadas em excitatórias ou inibitórias(BRADY et al., 2005). Por outro lado, também é possível uma classificação anatômica, dependendo dos locais de conexões entre as células (BRADY et al., 2005):

- axodendrítica: ligação entre um axônio e um dendrito;

- axossomática: ligação entre um axônio e o corpo celular;

- axoaxônica: ligação entre dois axônios;

- dendrodendrítica: ligação entre dois dendritos;

- somatossomática: ligação entre a soma (corpo celular) de dois neurônios;

- somatodendrítica: ligação entre a soma e o dendrito. 
O neurônio, ainda, pode-se conectar a ele mesmo, um fenômeno chamado de autápse (VAN DER LOOS; GLASER, 1972).

O modelo proposto é uma simplificação de uma sinapse axodendrítica típica, com apenas um tipo de receptor, do tipo AMPA (quisqualato) (HONORÉ et al., 1982). A ideia é investigar a dinâmica de uma sinapse simplificada mantendo aberta a possibilidade de melhorias posteriores no modelo, com elementos mais sofisticados.

\subsubsection{Definindo a resolução}

Uma das dificuldades enfrentadas, para incorporar no modelo previamente proposto uma sinapse, está na resolução espacial do reticulado. As dimensões de uma sinapse podem ser muito inferiores à dimensão do trecho de membrana utilizado nas simulações anteriores. A área de uma zona ativa de uma sinapse é estimada em 0,05-0,1 $\mu \mathrm{m}^{2}$ (SHENG et al., 2012; MEINRENKEN et al., 2002), enquanto a área de um único trecho de membrana utilizado no modelo descrito no capítulo anterior é de $10000 \mu \mathrm{m}^{2}$.

Uma possível forma de resolver o problema do conflito do tamanho da zona ativa e do tamanho do trecho de membrana poderia ser diminuindo o tamanho deste último, fazendo uma divisão muito mais fina do reticulado que discretiza o neurônio. Contudo, isso também faria com que o número de células do reticulado se tornasse muito maior, aumentando o tempo de simulação, e especialmente a quantidade de memória para a execução do programa.

No presente trabalho seguiu-se uma outra abordagem. No trecho de membrana onde ocorre a sinapse, foi criado um "sub-reticulado", uma subdivisão de cada trecho. Esse reticulado interno serve apenas para modelar a sinapse, mas está ligado ao potencial de membrana calculado no trecho de membrana em questão.

Nos demais trechos da membrana em que não há sinapse, o modelo continua como anteriormente, com apenas um reticulado. Assim, a granularidade da simulação muda conforme a necessidade, não havendo desperdício de tempo de processamento.

\subsection{O modelo da zona ativa}

Existem três elementos principais no modelo proposto de sinapse: canais de cálcio, íons de cálcio e as vesículas. No lado pré-sináptico do neurônio, as vesículas funcionam como pequenos reservatórios de neurotransmissores, previamente produzidos pelo neurônio e prontos para serem lançados na fenda sináptica (chamados de reservatórios 
de vesículas sinápicas, no inglês synaptic vesicle pools (RIZZOLI; BETZ, 2005)). As vesículas encontram-se presas à membrana por meio de proteínas chamadas SNARES, que são sensíveis à presença de íons de cálcio (BEAR et al., 2007; STERRATT et al., 2011). De forma simplificada, pode-se dizer que quando a tensão de membrana abre os canais iônicos permeáveis ao cálcio, a entrada desses íons ativa as proteínas SNARES, que se fundem à parede celular, liberando seu conteúdo. Posteriormente, essas vesículas podem ser novamente preenchidas com neurotransmissores, formando um ciclo (SÜDHOF, 1995, 2004; RIZZOLI; BETZ, 2005).

Existe uma grande variação nas dimensões da zona ativa, especialmente com relação aos tamanhos utilizados em simulações. Em Südhof (2012), estima-se que as zonas ativas, cuja superfície é circular, tenham um diâmetro entre $0,2 \mu m$ e $0,5 \mu m$. Em Dittrich et al. (2013), a zona ativa simulada possui um tamanho de $1,13 \mu \mathrm{m} \times 1,52 \mu \mathrm{m}$. No modelo de Pan e Zucker (2009), utiliza-se um valor de 1,6 $\mu \mathrm{m} \times 1,6 \mu \mathrm{m}$.

Devido à grande variabilidade de valores encontrados na literatura, optou-se por não criar um limite específico para o tamanho da zona ativa. Em vez disso, criou-se um reticulado de $100 \times 100$, em que cada quadrado corresponde a uma região de $50 \mathrm{~nm} \times 50 \mathrm{~nm}$, que é aproximadamente o tamanho de uma vesícula com neurotransmissores (DITTRICH et al., 2013).

O modelo proposto é bidimensional, simplificando as simulações. Existem modelos super-realistas de zonas ativas, como o modelo tridimensional da junção neuromuscular do sapo (DITTRICH et al., 2013). Nessa abordagem, cada vesícula foi modelada como uma esfera e o movimento é simulado no espaço tridimensional. Essa abordagem é muito precisa e detalhada, mas extremamente custosa do ponto de vista computacional. No modelo utilizado no presente trabalho, a abordagem é similar ao funcionamento de um autômato celular ou um sistema multiagente bidimensional (DE OLIVEIRA, 2010; UHRMACHER; WEYNS, 2009; GRIMM; RAILSBACK, 2013).

O reticulado menor, representando a zona ativa, pode conter canais iônicos de cálcio em algumas das suas posições. Esses são os únicos canais representados dentro do reticulado menor (o reticulado maior continua sendo igual ao modelo apresentado no capítulo anterior).

Os canais de cálcio agem como uma fonte de íons: quando o canal abre, um agente, representando um íon de cálcio, é colocado em uma das vizinhanças do canal (norte, sul, leste e oeste), de forma aleatória.

Do ponto de vista do modelo apresentado, o canal de cálcio funciona de forma similar ao canais de sódio ou potássio, tendo três estados: "fechado", "abrindo" e "aberto", com 
a seguinte ordem de ativação: fechado $\longrightarrow$ abrindo $\longrightarrow$ aberto $\longrightarrow$ fechado. O estado padrão é o estado fechado, no qual o canal permanece por tempo indeterminado enquanto $E_{\text {memb }}[t]<E_{\text {CaLimAb }}$. O estado "abrindo" é um estado intermediário em que o canal está mudando de conformação, seguido pelo estado "aberto", que é o estado que permite a entrada dos íons de cálcio dentro da célula. Os estados $s_{C a}$ do canal podem ser descritos pela equação:

$s_{\text {Ca }}[t+1]= \begin{cases}\text { fechado, } & \text { se }\left(E_{\text {memb }}[t]<E_{\text {CaLimAb }} \wedge s_{C a}[t]=\text { fechado }\right) \\ & \vee\left(t_{\text {CaAberto }} \geq \delta_{\text {CaAberto }} \wedge s_{C a}[t]=\text { aberto }\right) \\ \text { abrindo, }, & \text { se }\left(E_{\text {memb }}[t] \geq E_{\text {CaLimAb }}\right) \wedge\left(s_{C a}[t]=\text { fechado } \vee s_{\text {Ca }}[t]=\text { abrindo }\right) \\ & \wedge\left(t_{\text {CaAbrindo }}<\delta_{\text {CaAbrindo }}\right) \\ & \text { se }\left(t_{\text {CaAberto }}<\delta_{\text {CaAberto }}\right) \wedge\left(s_{C a}[t]=\text { aberto }\right) \\ & \left.\vee\left(t_{\text {CaAbrindo }} \geq \delta_{\text {CaAbrindo }}\right) \wedge s_{\text {Ca }}[t]=\text { abrindo }\right)\end{cases}$

O agente que representa o íon de cálcio pode se deslocar livremente pelo reticulado, escolhendo uma direção aleatória a cada instante da simulação e se deslocando para o vizinho adjacente. Existe uma probabilidade de $30 \%$ do íon de cálcio ser retirado da simulação, o que representa a possibilidade do íon se difundir para longe da zona ativa da sinapse (internamente ao neurônio). O íon de cálcio também pode ser retirado da simulação se ele atravessar uma das fronteiras do reticulado.

Entretanto, se o íon de cálcio entrar em uma posição na qual existe uma vesícula de neurotransmissores, ocorre uma interação. Se uma vesícula interagir com 8 íons de cálcio (não necessariamente ao mesmo tempo), ocorre a fusão da vesícula com a membrana (STANLEY, 1997; STEIN et al., 2007; SÜDHOF, 2013b, 2013a) (em Dittrich et al. (2013) é utilizado um valor de quatro interações, mas se obteve resultados melhores nas simulações com oito em vez de quatro interações). Após a interação de um íon de cálcio com uma vesícula, o íon é retirado da simulação.

Uma vez que a vesícula tenha liberado o seu conteúdo na fenda sináptica, ela pode ser absorvida pela membrana (BEAR et al., 2007; STERRATT et al., 2011) ${ }^{1}$ sendo então reciclada, repreenchida com neurotransmissores. Nessa situação, uma nova vesícula pode

1 O processo de interação entre a vesícula e a membrana pode possuir variações, como a possibilidade de fusão total com a membrana ou uma fusão parcial muito rápida, também chamada de "beijar e correr" (kiss and run). Essas diferentes possibilidades podem afetar algumas etapas desse processo (HE; WU, 2007). Contudo, essas diferentes estratégias iriam aumentar de forma considerável a complexidade do modelo, não sendo adequadas para um modelo simplificado. 
tomar o seu lugar, enquanto a vesícula antiga, agora novamente preenchida, pode ir para uma reserva de vesículas dentro da célula (STERRATT et al., 2011; RIZZOLI; BETZ, 2005).

\subsection{A fenda sináptica}

Para simular o ciclo de reabsorção, preenchimento e deslocamento das vesículas, utiliza-se uma simplificação do processo biológico: a vesícula permanece no mesmo local do reticulado, mas possui um intervalo de inativação, no qual ela não interage com a membrana. Esse intervalo corresponde ao período no qual uma vesícula deve se deslocar e se conectar à membrana, saindo do reservatório interno de vesículas (STERRATT et al., 2011).

Além disso, cada vesícula possuí uma quantidade fixa de neurotransmissores (2000 moléculas), de acordo com a teoria da liberação quantal (WU et al., 2007; BEAR et al., 2007; STERRATT et al., 2011). Os neurotransmissores são adicionadas à fenda sináptica cada vez que ocorre um evento de fusão.

Neurotransmissores liberados na fenda sináptica não ficam eternamente disponíveis. Eles podem se difundir para fora da fenda sináptica, sendo absorvidos pela glia (AULD; ROBITAILLE, 2003); podem ser reabsorvidos pelo neurônio que originou as vesículas (MASSON et al., 1999); podem ser destruídos por enzimas liberadas na fenda sináptica, como é o caso da acetilcolina com a enzima acetilcolinesterase (QUINN, 1987); ou podem se difundir até o neurônio pós-sináptico, potencialmente afetando receptores contidos na membrana pós-sináptica (como é o caso da serotonina e dos receptores 5-HT 1 (BRADY et al., 2005)).

Alem do processo de absorção, deve-se incorporar a dinâmica dos neurotransmissores na fenda sináptica. Dado que os processos mencionados podem ocorrer todos ao mesmo tempo, a concentração dos neurotransmissores é função de um conjunto de fatores simultâneos. Também sabe-se que a dinâmica da fenda sináptica implica um tempo de decaimento da concentração dos neurotransmissores (SCIMEMI; BEATO, 2009).

No modelo apresentado, incorporam-se esses fenômenos da seguinte forma: a fenda sináptica em si torna-se um agente (fixo) do modelo. Ela tem a finalidade de conectar dois neurônios e possui uma dinâmica específica. A concentração de neurotransmissores na fenda sináptica a cada instante de tempo $t$ é dada por $c_{\text {fenda }}$. O total de neurotransmissores liberados na fenda sináptica a cada instante é dado por $\sigma_{\text {libneu }}[t]$. Dessa forma, considerando que uma parcela dos neurotransmissores é perdida, e que uma parcela $\gamma$ permanece na fenda, pode-se descrever a dinâmica da fenda pela equação (5.1): 


$$
c_{\text {fenda }}[t+1]=\sigma_{\text {libneu }}[t]+\gamma \times c_{\text {fenda }}[t]
$$

O parâmetro $\gamma$ é um número entre 0 e 1 , e é ajustado de acordo com o tempo de decaimento $\tau_{d e c}$ desejado. No caso, utilizou-se o valor $\gamma=1$ que resulta em um $\tau_{d e c}$ de 1,5ms (SCIMEMI; BEATO, 2009).

\subsection{O lado pós-sináptico}

O terceiro elemento fundamental de uma sinapse corresponde ao lado pós-sináptico, onde se localiza a densidade pós-sináptica (no inglês PSD-Postsynaptic density) (ZIFF, 1997; KENNEDY, 2000; O'BRIEN et al., 1998). Normalmente localizado no dendrito, o lado pós-sináptico é responsável por receber os neurotransmissores e responder com uma mudança no potencial de membrana (como os PEPS ou PIPS), ou ainda responder com uma cadeia de reações químicas (BEAR et al., 2007; KANDEL et al., 2012; PURVES et al., 2012; STERRATT et al., 2011). Em muitas sinapses, a densidade pós-sináptica está presente em estruturas chamadas espinhos dendríticos, que são pequenas protuberâncias que permitem o contato entre as células (PURVES et al., 2012).

O lado pós-sináptico contém os receptores AMPA, que são sensíveis aos neurotransmissores liberados na fenda sinápica. Esses receptores são sensíveis à concentração do glutamato, em vez de serem sensíveis à tensão. No modelo proposto eles possuem apenas dois estados: aberto e fechado. A abertura ocorre assim que a concentração do glutamato no trecho de membrana onde o receptor se localiza for maior que um limiar, no caso, quatro. Esse limiar foi estabelecido com base no fato de que os receptores ionotrópicos de glutamato (iGluRs) são formados a partir de quatro ou cinco subunidades (PAAS, 1998). Além disso, a cada iteração em que o receptor permanece aberto, quatro moléculas são retiradas da concentração local de glutamato. Finalmente, quando essa concentração se torna inferior ao limiar de abertura (quatro), o canal se fecha. O canal pode se fechar após um tempo de 500 iterações (o que equivale a $500 \mu s$ ), valor que foi selecionado baseado no tempo de subida médio encontrada em pesquisas com esse tipo de canal (KLEPPE; ROBINSON, 1999).

\subsubsection{O cálculo do potencial na membrana pós-sináptica}

No lado pós-sináptico, foi utilizado um modelo similar do axônio para o cálculo do potencial de membrana. O objetivo é garantir que o formato e o pico do potencial da membrana 
pós-sináptico (PEPS) esteja de acordo com o formato desejado (no caso, o potencial gerado pelo glutamato nos receptores AMPA (PURVES et al., 2012)).

Para estimar os parâmetros desejados, considera-se que a zona ativa simulada possui $0,7 \mu \mathrm{m}^{2}$. De acordo com (TANAKA et al., 2005), a densidade de receptores AMPA é de $1280 \frac{\text { receptores }}{\mu m^{2}}$. Logo, simulou-se um total de 600 receptores AMPA.

Receptores AMPA são permeáveis a diversos íons, como sódio, potássio e até mesmo cálcio (em alguns casos) (ROGAWSKI, 2011; PURVES et al., 2012; BEAR et al., 2007). Dessa forma, para calcular o potencial de membrana, adiciona-se um termo numAMPA $A_{a b}[t]$

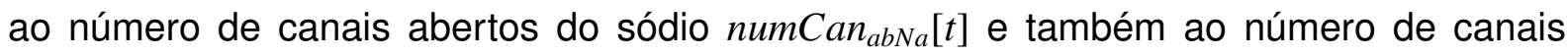
abertos do potássio $\operatorname{numCan}_{a b K}[t]$, que corresponde ao número de receptores AMPA no estado aberto, dividido por um fator $\xi$. Esse fator ajusta o valor máximo de despolarização causado pela liberação do glutamato, (o pico do PEPS). Portanto:

$$
\begin{aligned}
p_{a b N a}[t] & =\frac{\operatorname{numCan}_{a b N a}[t]+\frac{\operatorname{numAMPA_{ab}[t]}}{\xi}}{\operatorname{totCan}} \\
p_{a b K}[t] & =\frac{\operatorname{numCan}_{a b K}[t]+\frac{n u m A M P A_{a b}[t]}{\xi}}{\operatorname{totCan}}
\end{aligned}
$$

Dessa forma, $p_{a b N a}[t]$ e $p_{a b K}[t]$ correspondem às proporções corrigidas dos canais de sódio e potássio, respectivamente. Deve-se observar também que no presente modelo, na região pós-sináptica, o número de canais de sódio e de potássio é zero, sendo que apenas o termo $\frac{n u m A M P A_{a b}[t]}{\xi}$ é calculado para ambos os casos (logo, $\left.p_{a b K}[t]=p_{a b N a}[t]\right)$. Nas simulações foi utilizado $\xi=1000$, ajustado de acordo com o pico do PEPS desejado.

O modelo sinápico proposto é uma simplificação das sinapses reais. Especialmente no sistema nervoso central, sinapses químicas são extremamente complexas, envolvendo a interação de um grande número de substâncias, canais, receptores e íons (BEAR et al., 2007; PURVES et al., 2012; KANDEL et al., 2012; STERRATT et al., 2011). Contudo, o objetivo neste trabalho é propor um modelo simples, mas ainda capaz de exibir propriedades úteis. O modelo pode ser melhorado, com a finalidade de se incorporar outros aspectos. Por outro lado, o modelo proposto é bem mais sofisticado que o de muitas redes neurais artificiais propostas na literatura, em que as sinapses são apenas números reais que "conectam" neurônios. 
Figura 5.1: Estrutura geral da zona ativa.

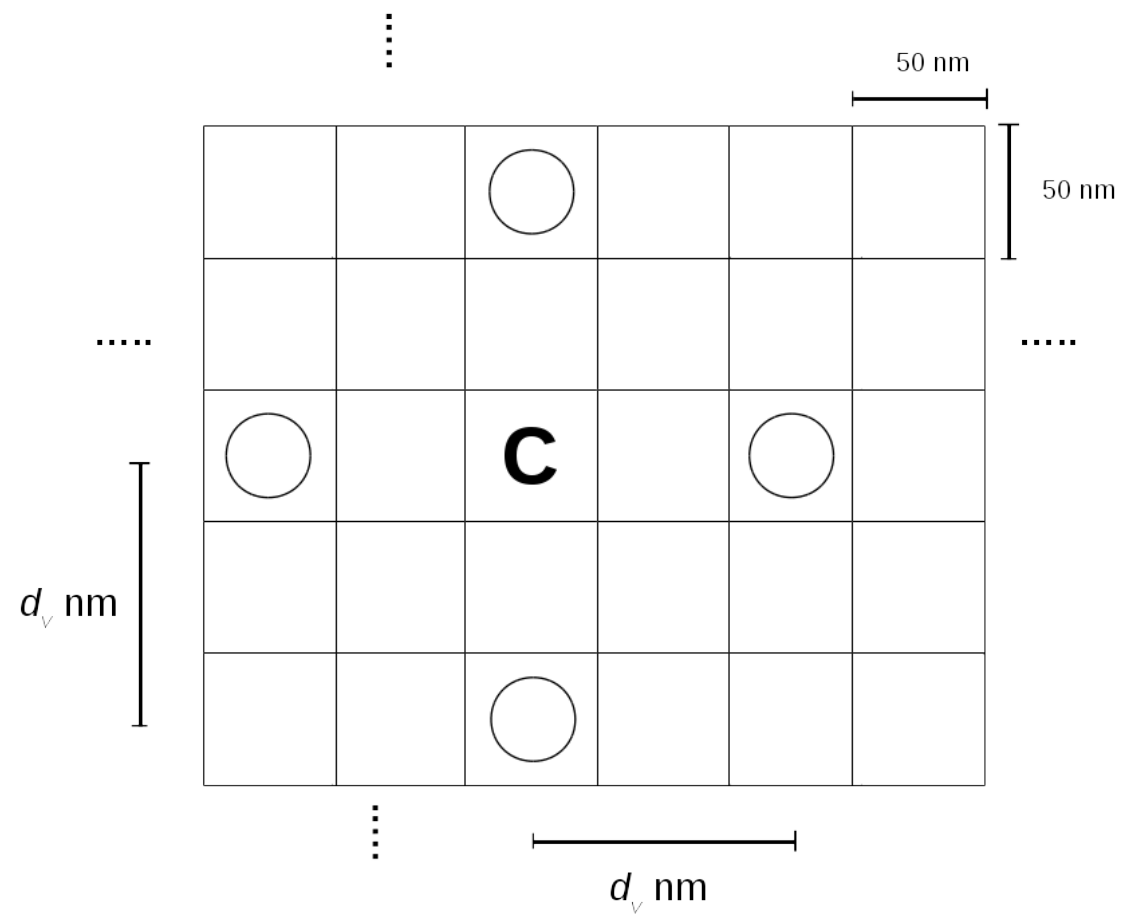

Fonte: Autor.

\subsection{Resultados}

A estrutura geral da zona ativa é mostrada na figura (5.1). Nesse primeiro modelo, apenas um canal de cálcio (denotado por c na figura) está no centro do reticulado, com quatro vesículas fixas ao redor do canal, todas distantes $d_{v}$ do canal central.

O comportamento do canal de cálcio é similar ao comportamento dos canais de sódio e potássio propostos anteriormente, exceto que nesse caso, quando o canal se abre, em vez de simplesmente mudar a tensão do trecho de membrana, ocorre a liberação de um íon de cálcio como um agente independente capaz de se deslocar livremente pela membrana (os íons de cálcio não estão representados na figura 5.1). Observe ainda que apenas os íons de cálcio podem se deslocar no reticulado, sendo os demais agentes fixos. 


\subsubsection{Resultados para uma zona ativa simples}

Se, por um lado, foi utilizado um modelo de comportamento dos canais iônicos determinista, o comportamento dos íons deve ter um componente estocástico. No modelo proposto, o deslocamento desses íons no reticulado ocorre de forma aleatória, sendo que a cada instante o agente que representa o íon deve sortear a direção de deslocamento (norte, sul, leste e oeste), sempre se deslocando de um único quadrado no reticulado, a cada passo de tempo.

A justificativa para a incorporação do componente aleatório foi baseado no artigo Über die von der molekularkinetischen Theorie der Wärme geforderte Bewegung von in ruhenden Flüssigkeiten suspendierten Teilchen(em português, Sobre o movimento de pequenas partículas suspensas em um líquido estacionário de acordo com a teoria molecular-cinética do calor ) (EINSTEIN, 1905). Esse artigo foi uma das primeiras análises rigorosas do movimento browniano, inicialmente observado por Brown (1828), mostrando o caráter essencialmente estocástico desse tipo de fenômeno. De acordo com Feynman et al. (2008): “... se olharmos para partículas minúsculas (coloides) em água através de um microscópio excelente, observaremos um movimento perpétuo das partículas, que é o resultado do bombardeamento dos átomos. Isso é chamado de movimento browniano".

Na simulação executada, um trem de pulsos é aplicado no início do axônio pré-sináptico, sendo uma onda quadrada com valor máximo de $40 \mathrm{mV}$, valor mínimo igual à tensão de repouso da membrana, período de $44 m s$ e ciclo de trabalho (duty cycle) de $9 \%$. Esse trem de pulsos simula um estímulo ou trem de potenciais de ação vindo de outros neurônios. Foram simuladas 300000 iterações $(300 \mathrm{~ms})$.

Devido ao caráter aleatório do movimento dos íons de cálcio, é importante realizar muitas simulações, para tentar evitar conclusões baseada em artefatos (ou eventos incomuns). Foram feitas 100 execuções, e o potencial de membrana pós-sináptico obtido foi o resultado da média dessas execuções. O resultado pode ser observado na figura (5.2), sendo que a curva com linha cheia representa a média do potencial na membrana póssináptica, no mesmo ponto onde ocorre a sinapse (na geometria do problema, na posição $x=0$ e $y=0$ da membrana pós-sináptica) e a linha pontilhada representa uma função alfa ${ }^{2}$ (STERRATT et al., 2011; RALL, 1967), para comparação, obtida de acordo com a equação $f_{\text {alfa }}(t)=18.75\left(t-t_{s}\right) e^{\frac{-\left(t-t_{s}\right)}{60 \mu \mu s}}$.

2 A condutância de uma sinapse pode ser modelada matematicamente por alguns tipos de funções, como uma exponencial simples, a função alfa ou a diferença de duas exponenciais. A escolha depende de um compromisso entre simplicidade e precisão, sendo que a função alfa é normalmente considerada uma boa aproximação (STERRATT et al., 2011). 
Figura 5.2: Comparação do potencial de membrana pós-sináptico. Na simulação, $d_{v}=5 \mathrm{~nm}$ (para cada quadrado). A linha tracejada é o gráfico de uma função alfa com $\tau_{m}=660 \mu \mathrm{s}$ enquanto a linha contínua é a média de 100 execuções do modelo. A figura corresponde apenas ao primeiro PEPS.

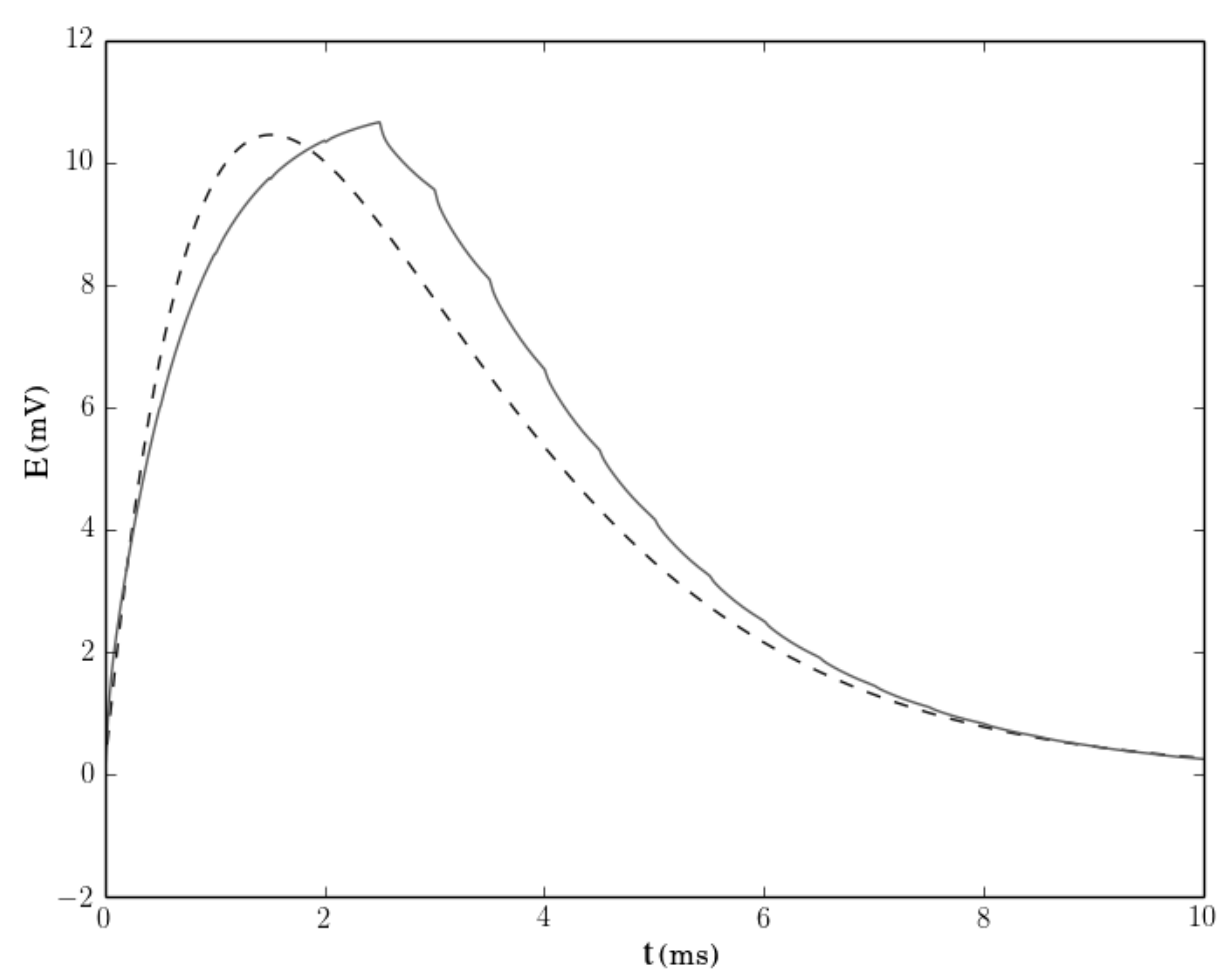

Fonte: Autor.

\section{Simulação com dois canais de cálcio}

Nessa simulação, foi adicionado mais um canal de cálcio, com uma geometria de acordo com a figura (5.3). Além do parâmetro $d_{v}$, que é a distância entre os canais e à vesícula, também foi adicionado o parâmetro $d_{c}$, a distância entre os dois canais.

Uma das formas de avaliar o efeito da distância entre os canais iônicos é observando quantos PEPS são gerados a partir de um mesmo estímulo, para diferentes distâncias entre os canais (o parâmetro $d_{c}$ ). Essa é uma forma de medir a "confiabilidade da conexão" entre os neurônios. Devido ao caráter estocástico de parte do modelo, é necessário fazer um conjunto de simulações. Dois aspectos devem ser levados em consideração:

- é preciso variar a distância entre os canais $d_{c}$ e observar o comportamento do sistema para cada distância; 
Figura 5.3: Zona ativa com dois canais de cálcio.

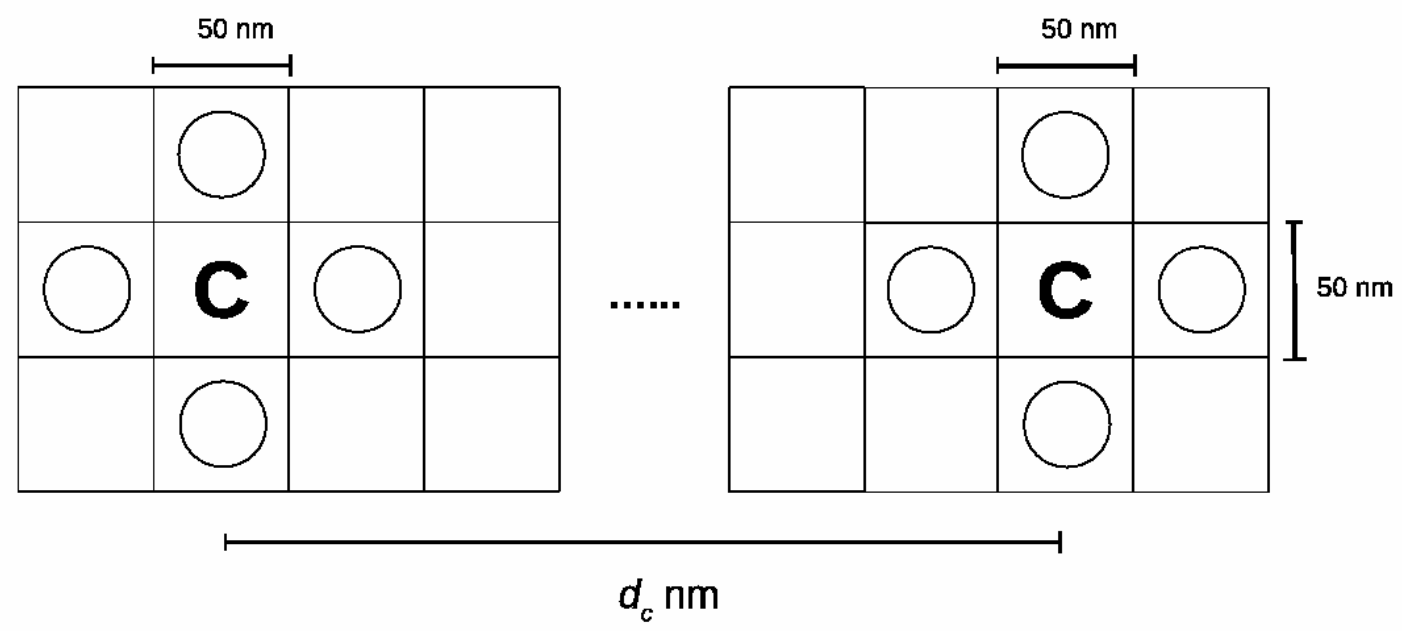

Fonte: Autor.

- cada valor deve resultar de uma média, para evitar artefatos devido ao comportamento aleatório dos íons.

Para cada distância $d_{c}$ foram feitas 20 execuções. Como medida do sucesso da comunicação, foram contados o número de picos no potencial da membrana pós-sináptica gerados ao longo da simulação. Foi utilizado um algoritmo simples de localização de picos: um máximo local (encontrado com uma estimativa de derivada próxima a zero). Em uma forma de onda real, com ruídos, esse tipo de abordagem não funcionaria, devido ao ruído. Contudo, o sinal obtido (das simulações) é bastante limpo, tendo picos claramente identificáveis.

Uma vez identificados os picos para cada execução, foi feita uma média e calculado o desvio padrão. O resultado é apresentado na figura (5.4). Nessa figura é possível observar o resultado da abordagem descrita tanto para a situação de um único canal, como para a situação com mais de um canal, e ainda variando-se a distância $d_{c}$ entre os dois canais. No eixo das abscissas tem-se a distância $d_{v}$ entre as vesículas e o canais de cálcio, sendo que essa distância é dada em múltiplos do número de células do reticulado (ou seja, em múltiplos de $50 \mathrm{~nm}$ ). No eixo das ordenadas tem-se o número médio de picos detectados (ou seja, o número de PEPS, não importado, nesse caso, o valor da amplitude máxima detectada). Além disso, foi calculado o desvio padrão (que só é mostrado no caso em que ele seja maior que zero). Em todas as execuções foi utilizado o mesmo estímulo, um trem de pulsos, o mesmo utilizado na simulação anterior. Cada execução simula $300 \mathrm{~ms}$ de atividade sinápica. 
Figura 5.4: Gráfico do número de potencias excitatório pós-sináptico versus a distância $d_{v}$ entre as vesículas, para diferentes configurações de canais.

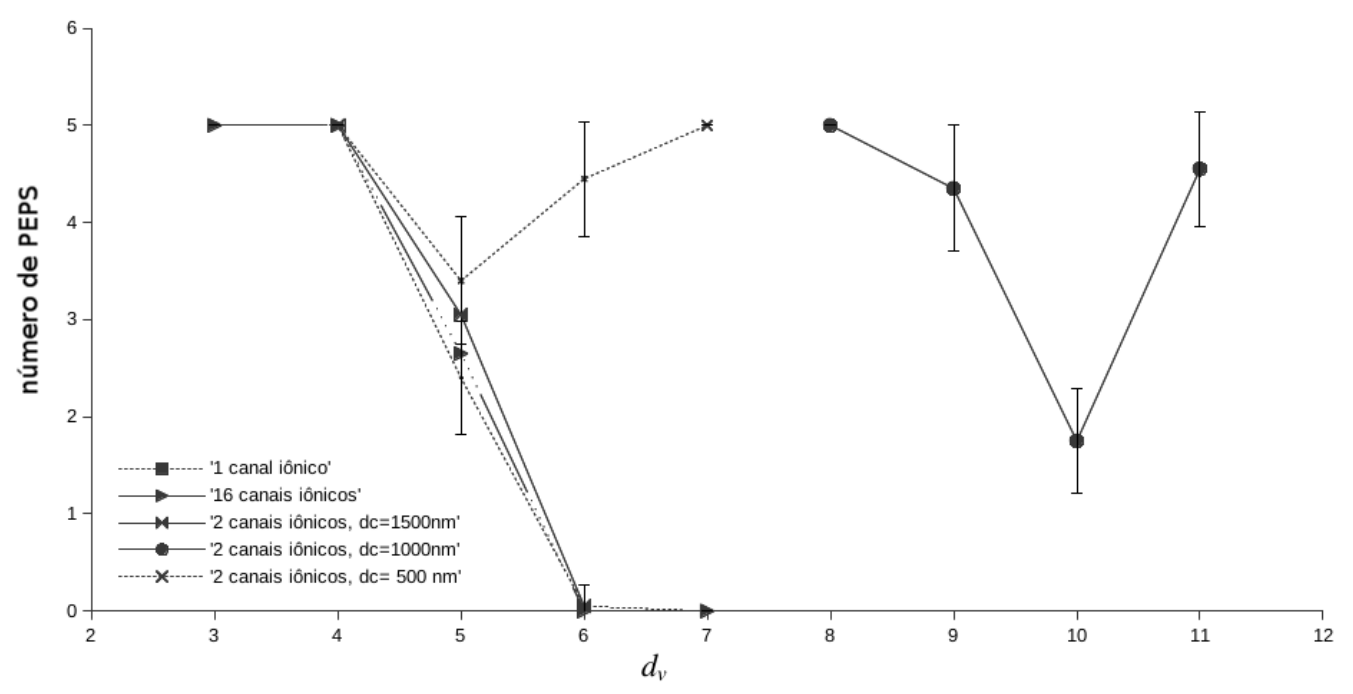

Fonte: Autor.

Ao observar o número de PEPS mostrados na figura (5.4)), pode-se ter uma ideia da eficiência da transmissão sinápica. No intervalo considerado (de 300 $\mathrm{ms}$ ), cinco pulsos foram aplicados no neurônio pré-sináptico. Isso significa que, considerando uma eficácia de $100 \%$, cinco PEPS deveriam ser observados no neurônio pós-sináptico. É possível identificar duas possíveis explicações para o caso quando se observam menos de cinco PEPS:

- ocorreu perda de informação na transmissão de um neurônio para outro ou;

- ocorreu um evento não-linear, potencialmente o processamento da informação.

Na figura (5.4) é possível observar que ao se variar as distâncias $d_{v}$ e $d_{c}$, pode-se alterar a quantidade de PEPS gerados no neurônio pós-sináptico. Isso indica que a estrutura pré-sináptica possui um caráter muito importante tanto na eficiência da transmissão da informação quanto no seu processamento.

\section{Simulação com um agrupamento de canais de cálcio}

Nessa simulação foi construído um agrupamento denso de 16 canais iônicos dentro de um quadrado, circundados por 16 vesículas. O objetivo é comparar o comportamento 
de uma situação com um pequeno números de canais versus uma situação em que a densidade e o número de canais é elevado. A geometria é ilustrada na figura (5.5). A estrutura dessa geometria é similar à encontrada em outros trabalhos (PAN; ZUCKER, 2009).

Figura 5.5: Agrupamento de canais iônicos de cálcio.

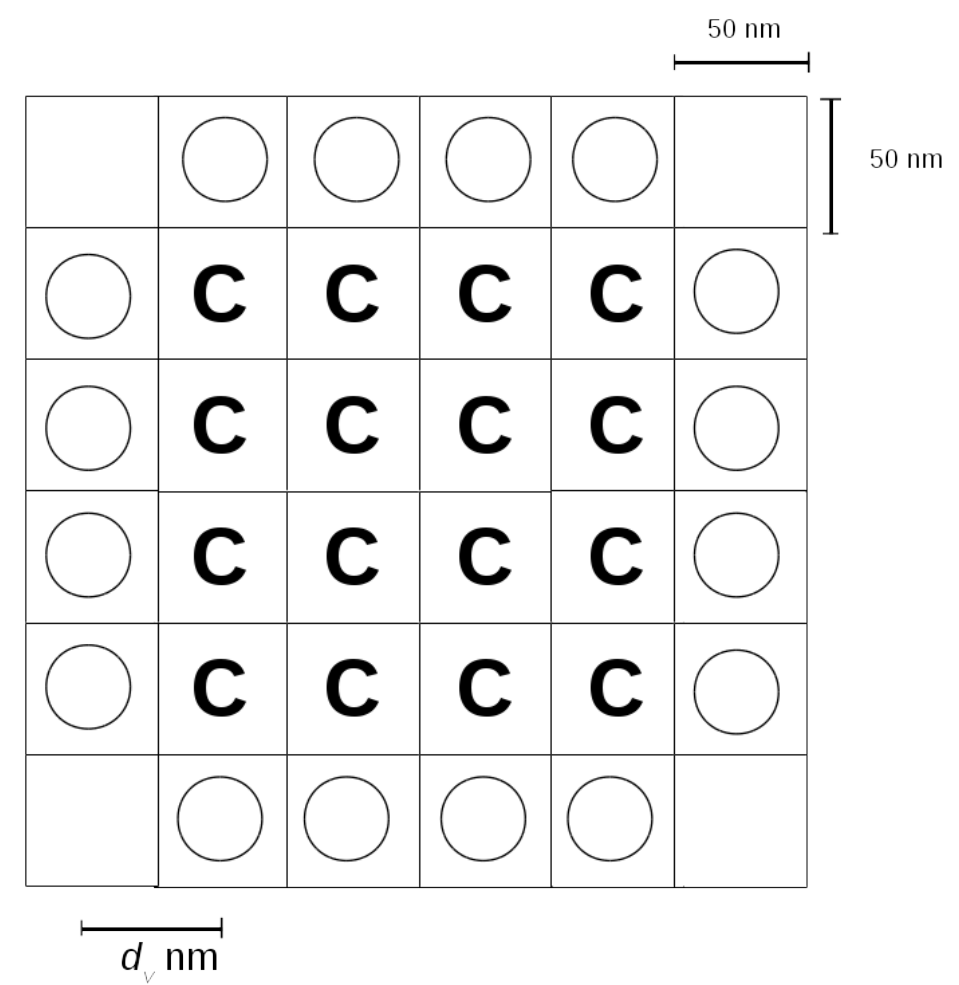

Fonte: Autor.

Primeiramente, é possível observar que o número de PEPS gerados não foi muito diferente das demais simulações, exceto para o caso com dois canais e $d_{c}=1000 \mathrm{~nm}$, que apresentou um número de PEPS muito superior. Esse resultado, que inicialmente pode parecer uma surpresa, apenas confirma uma observação há muito conhecida: as membranas não estão repletas de canais em elevada densidade (HILLE, 2001). Dessa forma, um grande agrupamento de canais não necessariamente implica um maior número de PEPS gerados.

Outro aspecto, que se pode observar na figura (5.6), é que o formato do PEPS gerado pelo agrupamento de canais é um pouco distorcido. Em vez de uma forma de onda similar à função alfa, o PEPS gerado parece ter sido "esticado". Esse comportamento pode ser explicado pelo fato de que um grande agrupamento de vesículas libera uma grande 
quantidade de neurotransmissores, levando a uma maior concentração na fenda sináptica. Como no modelo implementado o número de receptores AMPA é fixo, a amplitude máxima do PEPS é sempre a mesma, mas a maior concentração de neurotransmissores na fenda sináptica leva a uma duração maior do PEPS. Logo, pode-se concluir que esse comportamento está de acordo com o sistema biológico modelado.

Figura 5.6: PEPS gerados por um agrupamento de canais (linha contínua) comparado com a função alfa (linha tracejada, com os mesmos parâmetros da figura (5.2)).

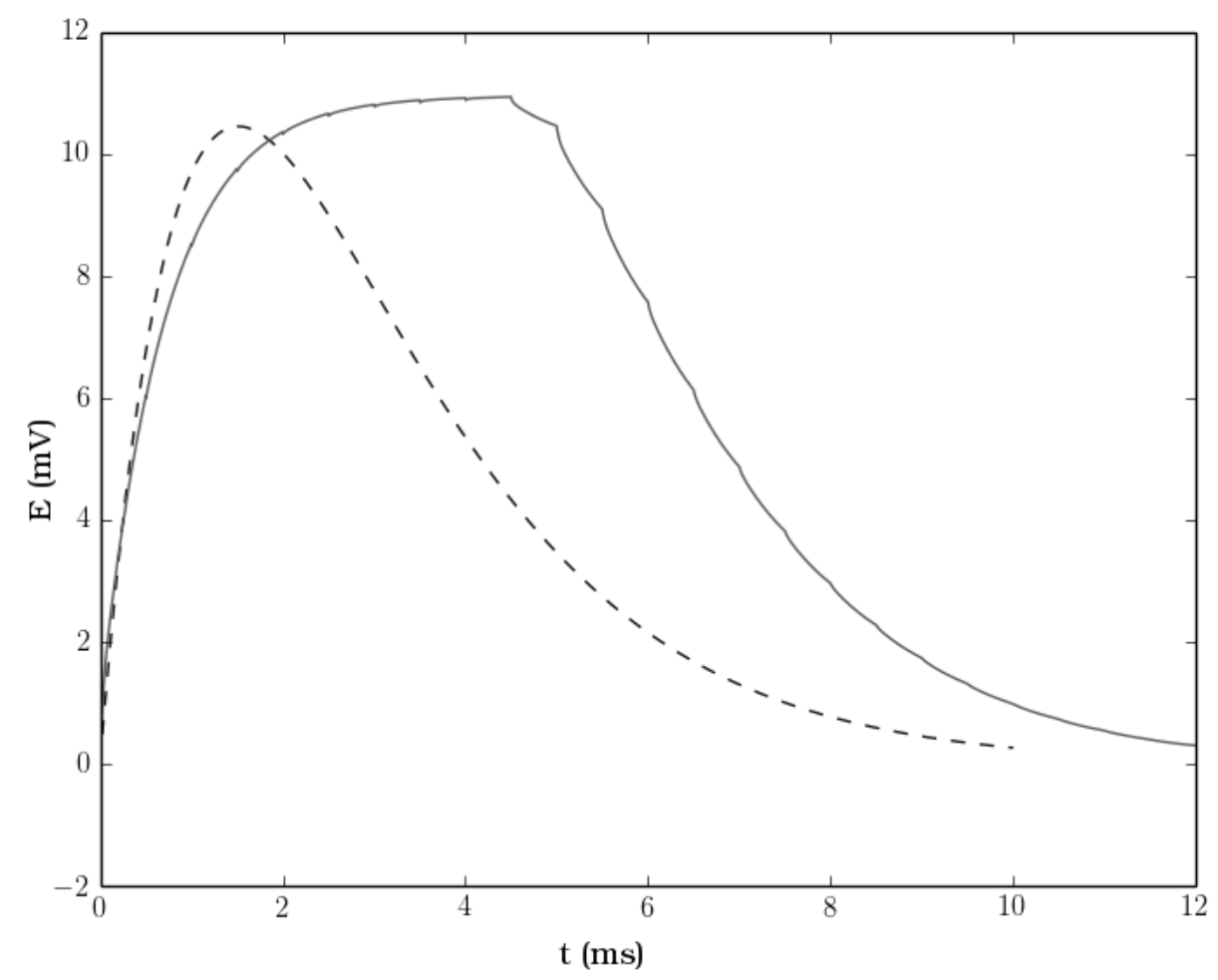

Fonte: Autor. 


\section{Capítulo 6}

\section{Conclusões}

The art of writing is the art of discovering what you believe.

Gustave Flaubert

Um dos aspectos mais fascinantes dos autômatos celulares, especialmente o "jogo da vida" de Conway (GARDNER, 1970), é como um conjunto de regras tão simples pode dar origem a um comportamento tão sofisticado, tendo computabilidade equivalente a qualquer máquina de Turing (ADAMATZKY; DURAND-LOSE, 2012). Isso significa que esse "jogo"1 é capaz de executar um algoritmo arbitrário ${ }^{2}$. Contudo, a estrutura básica do modelo é extremamente simples, sendo composto de apenas quatro regras locais. Muitos outros modelos de autômatos celulares também exibem comportamentos ricos, muitas vezes chamados de emergentes (WOLFRAM, 1983; HOLLAND, 2000).

Tendo-se em mente modelos dessa natureza, neste trabalho foi proposto um modelo de neurônio baseado em regras simples e locais, e capaz de reproduzir alguns resultados dos modelos convencionais de neurônios, como o disparo e propagação do potencial de ação, a propagação passiva do potencial na membrana, e o comportamento básico de uma sinapse.

Adotou-se como base do modelo o canal iônico, uma vez que o comportamento dos canais é fundamental para entender o funcionamento da rede neural (HILLE, 2001; KANDEL et al., 2012; BEAR et al., 2007). A natureza eletroquímica dos fenômenos celulares, especialmente do potencial de ação, sugere a adoção de um modelo que permita conexão e interação entre os fenômenos químicos e elétricos.

1 O nome mais correto seria modelo computacional.

2 Ou, mais corretamente, qualquer função computável. 
Modelos puramente elétricos dos fenômenos neurais possuem uma desvantagem. Nesse tipo de abordagem, qualquer fenômeno químico deve ser obrigatoriamente modelado como uma alteração de impedância, corrente elétrica ou tensão. Fenômenos que não possuam uma influência direta no potencial elétrico da membrana são mais difíceis de serem incorporados.

Um outro problema associado à abordagem tradicional baseado em circuitos elétricos é que essa teoria se baseia em uma discretização do eletromagnetismo de Maxwell $\left(\right.$ AGARWAL; LANG, 2005) ${ }^{3}$. Nesse processo, parte da informação geométrica de uma célula é perdida (o que é especialmente ruim no caso de um neurônio, que possui uma geometria complexa). Para mitigar esse problema, foi desenvolvida a técnica de análise de compartimentos, que emprega um conjunto de circuitos elétricos, cada um associado a uma certa posição espacial (STERRATT et al., 2011). Aspectos químicos são inseridos como modificações nas condutâncias envolvidas (KOCH; SEGEV, 1998).

Uma abordagem baseada em autômatos celulares, sendo uma discretização do espaço, é fundamentalmente geométrica. Os trechos da membrana possuem uma localização espacial específica, e interagem entre si seguindo regras locais. A estrutura básica do modelo é espacial e discreta.

Cada "célula" do modelo pode ter também uma natureza variada, representando fenômenos elétricos, químicos ou mecânicos. Em um modelo baseado em teoria de circuitos, as características elétricas formam a base do modelo, e ditam completamente sua dinâmica. Por outro lado, um modelo baseado na interação abstrata de agentes pode incorporar diferentes fenômeno físicos sem impor uma restrição que privilegie certos elementos sobre outros.

\subsection{A utilidade de diferentes modelos}

Herbert Stachowiak, em sua Teoria Geral da Modelagem (Allgemeine Modelltheorie) (STACHOWIAK, 1973), destaca que "um modelo não precisa capturar todos os atributos de um fenômeno original, mas apenas aqueles relevantes para o criador do modelo ou usuário deste mesmo"4. Esse é o aspecto "reducionista" da modelagem (no original "Verkürzungsmerkmal"). Além disso, Stachowiak destaca o aspecto pragmático da modelagem: quando

3 O termo utilizado em inglês é lumped element model, em que as características elétricas de um circuito são agrupadas em elementos com parâmetros específicos, como resistores, indutores e capacitores.

4 No original: Modelle erfassen im allgemeinen nicht alle Attribute des durch sie repräsentierten Originals, sondern nur solche, die den jeweiligen Modellerschaffern und/oder Modellbenutzern relevant scheinen. , tradução livre do autor. Infelizmente, o autor não tem conhecimento de nenhuma tradução do livro "Allgemeine Modelltheorie" de Stachowiak nem em inglês, nem em português ou em espanhol. 
se constrói um modelo, esse é feito tendo-se em mente alguém, um intervalo de tempo e um paradigma ${ }^{5}$. Esse é o aspecto pragmático ("Pragmatisches") da modelagem.

A abordagem seguida nesta tese busca simplificar o modelo do canal, com o objetivo de tornar a simulação mais rápida e, ao mesmo tempo, busca descrever o potencial de membrana diretamente a partir do modelo dos canais, com o objetivo de tornar o modelo da membrana mais realista.

Dessa forma, pode-se dizer que abordagem utilizada é simultaneamente emergente e reducionista. O axônio é modelado de um ponto de vista emergente, com o potencial de ação e a propagação da membrana sendo um fenômeno derivado da interação dos canais com a membrana (o reticulado). Por outro lado, o modelo dos canais é tipicamente reducionista, tendo-se levado em consideração apenas alguns elementos (macroscópicos) do seu funcionamento.

Ainda que usualmente o reducionismo seja visto como um ponto de vista rival dos modelos emergentes, deve-se ter em mente que modelos possuem níveis fenomenológicos. O nível mais atômico é quase sempre de natureza reducionista, normalmente originado de um conjunto de regras ou leis básicas que podem ser diretamente observadas e verificadas.

Contudo, conforme as partes interagem entre si, começam a surgir fenômenos de natureza emergente. Esses fenômenos decorrem das interações entre as partes básicas. Essas interações não estão explicitamente codificadas nas partes mais fundamentais do modelo, mas existem como uma possibilidade. Ao conectar diferentes elementos, tornase possível o surgimento de uma nova camada de comportamentos, que se vê como um fenômeno emergente.

No caso do neurônio, a membrana é o meio que conecta os canais iônicos. A interação dos canais com a membrana gera a possibilidade de diversos fenômenos, como o potencial de ação e potenciais de natureza gradual.

Quando neurônios são conectados por meio de sinapses, gerando uma rede neural, surge um novo universo de comportamentos. Esses comportamentos podem ser simples oscilações, ou, em outro extremo, o processamento complexo de informações. Essa nova camada de comportamentos também pode ser compreendida como um fenômeno emergente. Por esse motivo, é preciso ter cautela ao separar os modelos em emergentes ou

5 A frase no original é "Modelle sind ihren Originalen nicht per se eindeutig zugeordnet. Sie erfüllen ihre Ersetzungsfunktion a) für bestimmte - erkennende und/oder handelnde, modeltbenutzende - Subjekte, b) innerhalb bestimmter Zeit Intervalle und c) unter Einschränkung auf bestimmte gedankliche oder tatsächliche Operationen.". O trecho "gedankliche oder tatsächliche operationen" foi traduzido pelo autor como "paradigma". 
reducionistas. Modelos sofisticados podem possuir níveis emergentes e níveis reducionistas.

Outro aspecto que deve ser destacado é que, do ponto de vista da classificação dos diversos tipos de modelos científicos, como enumerado em (FRIGG; HARTMANN, 2009), pode-se dizer que o modelo de Hodgkin e Huxley é um modelo representativo de dados, ou seja, ele representa um conjunto de dados observados em um laboratório. Por outro lado, o modelo proposto neste trabalho poderia ser caracterizado como "um modelo idealizado típico de Galileu" (FRIGG; HARTMANN, 2009), (ou, potencialmente aristotélico): é uma simplificação da realidade diretamente baseada em uma idealização do fenômeno físico em questão (no caso, o potencial da membrana sendo fruto da interação dos canais iônicos).

\subsection{Algumas considerações sobre os resultados obtidos}

Nas próximas seções são feitas algumas observações sobre os resultados obtidos com o modelo proposto e sobre o significado desses resultados.

\subsubsection{O modelo axonal}

O modelo proposto apresentou um comportamento similar ao de Hodgkin e Huxley (HODGKIN; HUXLEY, 1952) ou FitzHugh-Nagumo (FITZHUGH, 1955). Contudo, em vez de ser baseado em um conjunto de equações diferenciais, o modelo é baseado diretamente no comportamento dos canais, sendo que cada canal é modelado com um conjunto de regras.

Uma das dificuldades ao se construir um modelo baseado no comportamento dos canais iônicos é que boa parte dos modelos que descrevem os canais tendem a ser extremamente complexos do ponto de vista computacional (MAFFEO et al., 2012; ROUX et al., 2004). Existem diversos tipos de modelos de canais, como os modelos quânticos (VAZIRI; PLENIO, 2010; KAUFMAN et al., 2015), modelos baseados em cadeias de Markov (MAFFEO et al., 2012; FINK; NOBLE, 2009), modelos baseados em dinâmica molecular (BECKER et al., 2001), entre outros. Para uma lista de várias possibilidades, consulte o artigo de Roux (ROUX et al., 2004).

Contudo, a finalidade de boa parte dos modelos de canais iônicos é modelar apenas um único canal (ou um conjunto pequeno de canais), com muito detalhes, em um intervalo de tempo muito pequeno. Nesses casos, o objetivo é obter uma descrição o mais deta- 
Ihada possível do comportamento do canal, mas não necessariamente de uma partição da membrana (muito menos de toda uma célula). Por esse motivo, simular um neurônio completo (ou, pior ainda, uma rede de neurônios) utilizando um modelo quântico de canal é ainda computacionalmente inviável.

Mesmo que a velocidade computacional necessária para simular um canal utilizando um modelo quântico complexo seja atingida algum dia, ainda sim pode ser útil ter um modelo mais simples, que permita uma simulação de redes neurais bem maiores, do que um modelo detalhado que permita apenas um número restrito de neurônios (supondo um mesmo poder computacional para ambas).

O modelo proposto do axônio é essencialmente determinista e, por ser baseado em um conjunto de regras simples e locais, pode ser rapidamente executado em um computador convencional. Diferentemente de modelos baseados na resolução numérica de equações diferenciais, o modelo proposto não apresenta problemas de convergência numérica. $O$ modelo também mostrou uma boa adequação com resultados vindos de laboratório (MIZUSEKI et al., 2009a, 2009b), sendo capaz de reproduzir os principais comportamentos observados em modelos baseados em equações diferenciais, como potenciais graduais e o disparo do potencial de ação.

\subsubsection{Curva de frequência versus corrente de entrada}

Ainda que a estrutura geral do modelo proposto corresponda a um neurônio do tipo-II, foi possível alterar seu comportamento para tipo-I, utilizando uma estratégia similar a de outros trabalhos (DRION et al., 2015).

O fato da estratégia para a mudança do tipo ser semelhante a utilizada nos modelos baseados nas equações de Hodgkin e Huxley é um indício de que o modelo apresentado se comporta de forma compatível com essas outras abordagens. As mudanças feitas foram coerentes com os princípios físicos que governam o comportamento dos canais.

\subsubsection{Sinapses e processamento}

Também foi construída uma extensão do modelo inicial, incorporando a sinapse. Foi utilizado como base uma sinapse excitatória típica (do neurotransmissor glutamato), com receptores AMPA.

Um aspecto fundamental na simulação da sinapse é que a geometria do posicionamento das vesículas e dos canais de cálcio tem uma profunda influência no seu comportamento. Pode-se inferir, baseado nessas observações, que a capacidade neural de 
transmitir e/ou processar informações está intimamente ligada à geometria dos canais e das vesículas na membrana pré-sináptica. Essa observação está de acordo com estudos que apontam para a organização microscópica da sinapse como um elemento fundamental (PHILLIPS et al., 2001; CINGOLANI; GODA, 2008; TURNER et al., 1999).

Uma das perguntas que cientistas vêm fazendo há décadas é com relação à origem da capacidade de processamento do cérebro humano (ROTH; DICKE, 2005). Essa pergunta ainda não tem uma resposta clara, mas é possível identificar alguma capacidade de processamento em um nível mais fundamental que o neurônio, nas próprias sinapses (KENNEDY, 2000; ABBOTT; REGEHR, 2004; PELAEZ; ANDINA, 2013). Fenômenos complexos, como a plasticidade cerebral, são frutos de processos que ocorrem em vários níveis, alguns microscópicos (como a química nas imediações da sinapse) outros macroscópicos (como a alteração de diversos circuitos cerebrais) (NEVES et al., 2008).

Dessa forma, não deveria ser uma surpresa quando observa-se, no modelo proposto, que a distribuição de vesículas e canais afeta a transmissão e processamento da informação. Essa observação indica ainda que o modelo possui aderência com a realidade, mesmo sendo bastante simplificado.

\subsection{Direções futuras de pesquisa baseadas no modelo proposto}

Os seguintes aspectos, em uma ordem crescente de dificuldade, foram abordados no presente trabalho:

- aspectos passivos de condução;

- geração e propagação do potencial de ação;

- adaptação da frequência de disparo;

- transmissão sináptica.

As simulações feitas exploraram situações relativamente simples, a fim de se verificar a qualidade do modelo proposto, e fazer diversos ajustes na sua estrutura básica.

Contudo, uma vez que foi verificada a aderência do modelo proposto, é possível partir para situações mais complexas. Um dos aspectos que pode ser explorado com esse modelo são geometrias neuronais mais sofisticadas. 
Outro aspecto que pode ser explorado é o efeito da diversidade dos canais iônicos. Especialmente no caso das sinapses, pode-se explorar o efeito da diversidade de receptores e o efeito dos diversos tipos de neurotransmissores. Adicionalmente, pode ser útil investigar o efeito da variação do número e tipo de canais na membrana ao longo do tempo (o chamado tráfego de receptores), e como isso afeta o comportamento dos neurônios e das sinapses (HENLEY; WILKINSON, 2013; KANDEL et al., 2012).

Trabalhos futuros também podem estudar a arquitetura dos circuitos neuronais e como ela se relaciona com o funcionamento de outros órgãos. Normalmente esse tipo de pequisa é feita com modelos que se utilizam de redes neurais artificiais convencionais (MCCLELLAND et al., 1995; PRENTICE et al., 2001). O modelo proposto pode ser utilizado como ponto de partida para a construção de outros modelos mais sofisticados de circuitos neuronais, levando em consideração aspectos físicos e químicos dos canais iônicos e da membrana.

O modelo proposto também pode ser útil para entender o efeito de substâncias psicoativas (PENDYAM et al., 2009; GHASEMZADEH et al., 2009). Como o modelo incorpora diretamente a dinâmica dos canais iônicos, pode ser possível explorar como tais substâncias afetam diretamente o seu funcionamento.

Deve-se destacar também que o modelo proposto não se restringe apenas à neurociência. A atividade das células beta do pâncreas também é profundamente influenciado pelos canais iônicos (BRAUN et al., 2008; MACDONALD; WHEELER, 2003). Nesse sentido, uma estrutura similar ao modelo proposto poderia ser utilizada para estudar doenças como a diabetes.

Células musculares também possuem canais iônicos (BEAR et al., 2007; RUDY, 2008; PURVES et al., 2012), sendo similares aos neurônios em alguns aspectos de seu funcionamento, e também podem ser modeladas utilizando uma modificação do modelo proposto. Há evidencias de que os canais iônicos têm um papel fundamental no tônus vascular e no sistema circulatório (JACKSON, 2000; BEECH, 2007; FIRTH et al., 2011), indicando que a abordagem proposta neste trabalho também pode ser util em outras áreas. 


\section{Referências Bibliográficas}

ABBOTT, L.F.; REGEHR, W.G. Synaptic computation. Nature, v. 431, n. 7010, p. 796-803, 2004.

ACEDO, L. A cellular automaton model for collective neural dynamics. Mathematical and Computer Modelling, v. 50, n. 5, p. 717-725, 2009.

ADAMATZKY, A.; DURAND-LOSE, J. Collision-Based Computing. London: Springer, 2012.

ADCOCK, S.A.; MCCAMMON, J.A. Molecular dynamics: survey of methods for simulating the activity of proteins. Chemical Reviews, v. 106, n. 5, p. 1589-1615, 2006.

AGARWAL, A.; LANG, J. Foundations of Analog and Digital Electronic Circuits. Amsterdam: [s.n.], 2005.

ALBERTS, B.; JOHNSON, A.; LEWIS, J.; RAFF, M.; ROBERTS, K.; WALTER, P. Molecular Biology of the Cell. New York: Garland Science, 2008.

ALIVISATOS, A.P.; CHUN, M.; CHURCH, G.M.; GREENSPAN, R.J.; ROUKES, M.L.; YUSTE, R. The brain activity map project and the challenge of functional connectomics. Neuron, v. 74, n. 6, p. 970-974, 2012.

ANDERSEN, S.S.L.; JACKSON, A.D.; HEIMBURG, T. Towards a thermodynamic theory of nerve pulse propagation. Progress in Neurobiology, v. 88, n. 2, p. 104-113, 2009.

ANDERSON, C.R.; STEVENS, C.F. Voltage clamp analysis of acetylcholine produced end-plate current fluctuations at frog neuromuscular junction. The Journal of Physiology, v. 235 , n. 3, p. $655-691,1973$.

ANDERSON, P.A.V.; GREENBERG, R.M. Phylogeny of ion channels: clues to structure and function. Comparative Biochemistry and Physiology Part B: Biochemistry and Molecular Biology, v. 129, n. 1, p. 17-28, 2001.

APPALI, R.; van Rienen, U.; HEIMBURG, T. A comparison of the hodgkin-huxley model and the soliton theory for the action potential in nerves. In: IGLIC, A. (Ed.). Cambridge, MA: Academic Press, 2012, (Advances in Planar Lipid Bilayers and Liposomes, v. 16). p. 275-299.

ASHBY, W.R. Design for a Brain. New York: Wiley, 1954.

AULD, D.S.; ROBITAILLE, R. Glial cells and neurotransmission: an inclusive view of synaptic function. Neuron, v. 40, n. 2, p. 389-400, 2003. 
AVELLA, O.J.; MUÑOZ, J.D.; FAYAD, R. Simulation of miniature endplate potentials in neuromuscular junctions by using a cellular automaton. Physica A: Statistical Mechanics and its Applications, v. 387, n. 2, p. 694-702, 2008.

BEAR, M.F.; CONNORS, B.W.; PARADISO, M.A. Neuroscience. Philadelphia: Lippincott Williams \& Wilkins, 2007.

BECHTEL, W. Mental Mechanisms: Philosophical Perspectives on Cognitive Neuroscience. New York: Routledge, 2008.

BECKER, O.M.; MACKERELL, A.D.; ROUX, B.; WATANABE, M. Computational Biochemistry and Biophysics. New York: Taylor \& Francis, 2001.

BEDI, G.; CARRILLO, F.; CECCHI, G.A.; SLEZAK, D.F.; SIGMAN, M.; MOTA, N.B.; RIBEIRO, S.; JAVITT, D.C.; COPELLI, M.; CORCORAN, C.M. Automated analysis of free speech predicts psychosis onset in high-risk youths. NPJ Schizophrenia, v. 1, 15030, 7 páginas, 2015.

$\mathrm{BEECH}$, D.J. Ion channel switching and activation in smooth-muscle cells of occlusive vascular diseases. Biochemical Society Transactions, v. 35, n. 5, p. 890-894, 2007.

BENDA, J.; HERZ, A.V.M. A universal model for spike-frequency adaptation. Neural Computation, v. 15, n. 11, p. 2523-2564, 2003.

BENNETT, M.V.L. Nicked by occam's razor: unitarianism in the investigation of synaptic transmission. Biological Bulletin, v. 168, n. 35, p. 159-167, 1985.

BENNETT, M.V.L. Gap junctions as electrical synapses. Journal of Neurocytology, v. 26, n. 6, p. 349-366, 1997.

BENNETT, M.V.L. Electrical synapses, a personal perspective (or history). Brain Research Reviews, v. 32, n. 1, p. 16-28, 2000.

BENNETT, M.V.L.; ZUKIN, R.S. Electrical coupling and neuronal synchronization in the mammalian brain. Neuron, v. 41, n. 4, p. 495-511, 2004.

BOWER, J.M.; BOLOURI, H. Computational Modeling of Genetic and Biochemical Networks. Cambridge, Mass.: MIT Press, 2001.

BRADY, S.; SIEGEL, G.; ALBERS, R.W.; PRICE, D. Basic Neurochemistry: Molecular, Cellular and Medical Aspects. Amsterdam: Elsevier Science, 2005.

BRAUN, M.; RAMRACHEYA, R.; BENGTSSON, M.; ZHANG, Q.; KARANAUSKAITE, J.; PARTRIDGE, C.; JOHNSON, P.R.; RORSMAN, P. Voltage-gated ion channels in human pancreatic $\beta$-cells: electrophysiological characterization and role in insulin secretion. Diabetes, v. 57, n. 6, p. 1618-1628, 2008.

BREHM, P.; OKAMURA, Y.; MANDEL, G. Ion channel evolution. Seminars in Neuroscience, v. 3, n. 5, p. 355-367, 1991. 
BRETTE, R.; GERSTNER, W. Adaptive exponential integrate-and-fire model as an effective description of neuronal activity. Journal of Neurophysiology, v. 94, n. 5, p. 3637-3642, 2005.

BROWN, R. A brief account of microscopical observations made in the months of june, july and august 1827, on the particles contained in the pollen of plants; and on the general existence of active molecules in organic and inorganic bodies. Philosophical Magazine Series 2, v. 4, n. 21, p. 161-173, 1828.

BRUNEL, N.; HAKIM, V.; RICHARDSON, M.J.E. Single neuron dynamics and computation. Current Opinion in Neurobiology, v. 25, p. 149-155, 2014.

CAMAZINE, S. Self-organization in Biological Systems. Princeton: Princeton University Press, 2003. (Princeton Studies in Complexity).

CANNON, R.C.; D'ALESSANDRO, G. The ion channel inverse problem: neuroinformatics meets biophysics. PLoS Computational Biology, v. 2, n. 8, p. 0862-0869, 2006.

CANTOR, R.S. The lateral pressure profile in membranes: a physical mechanism of general anesthesia. Biochemistry, v. 36, n. 9, p. 2339-2344, 1997.

CAPENER, C.E.; KIM, H.J.; ARINAMINPATHY, Y.; SANSOM, M.S.P. Ion channels: structural bioinformatics and modelling. Human Molecular Genetics, v. 11, n. 20, p. 2425-2433, 2002.

CARVALHO, T. A colorized scanning electron microscope picture of a nerve ending. CIL:214: The cell: An image library. 2010. Disponível em: <http://www. cellimagelibrary.org/images/214>. Acesso em: 04 nov. 2014.

CHEN, Y.; FRANK, H.Y.; SURMEIER, D.J.; SCHEUER, T.; CATTERALL, W.A.

Neuromodulation of na+ channel slow inactivation via camp-dependent protein kinase and protein kinase c. Neuron, v. 49, n. 3, p. 409-420, 2006.

CHENG, Y.; SUEN, J.K.; RADIĆ, Z.; BOND, S.D.; HOLST, M.J.; MCCAMMON, J.A. Continuum simulations of acetylcholine diffusion with reaction-determined boundaries in neuromuscular junction models. Biophysical Chemistry, v. 127, n. 3, p. 129-139, 2007.

CHURCHLAND, P.S. Neurophilosophy: Toward a Unified Science of the Mind-brain. Cambridge, Mass.: MIT Press, 1989.

CHURCHLAND, P.S. Brain-wise: Studies in Neurophilosophy. Cambridge, Mass.: MIT Press, 2002.

CINGOLANI, L.A.; GODA, Y. Actin in action: the interplay between the actin cytoskeleton and synaptic efficacy. Nature Reviews Neuroscience, v. 9, n. 5, p. 344-356, 2008.

CLARKE, R.J.; KHALID, M.A.A. Pumps, Channels and Transporters: Methods of Functional Analysis. Hoboken: Wiley, 2015.

COLE, K.S.; HODGKIN, A.L. Membrane and protoplasm resistance in the squid giant axon. The Journal of General Physiology, v. 22, n. 5, p. 671-687, 1939. 
CONLEY, E.C.; BRAMMAR, W.J. The Ion Channel FactsBook. London: Academic Press, 1999. (Factsbook Series, v. 4).

CONNOR, J.A.; WALTER, D.; MCKOWN, R. Neural repetitive firing: modifications of the hodgkin-huxley axon suggested by experimental results from crustacean axons. Biophysical Journal, v. 18, n. 1, p. 81-102, 1977.

CORREALE, T.G.; MONTEIRO, L.H.A. On the dynamics of axonal membrane: Ion channel as the basic unit of a deterministic model. Applied Mathematics and Computation, v. 291, p. 292-302, 2016.

CORREALE, T.G.; MONTEIRO, L.H.A. Typical frequency-current curves of neurons obtained from a model based on cellular automaton. Applied Mathematics and Computation, v. 304, p. 136-141, 2017.

DE OLIVEIRA, P.P.B. Drima: A minimal system for probing the dynamics of change in a reactive multi-agent setting. The Mathematica Journal, v. 12, n. 3-5, p. 1-18, 2010.

DEGRÈVE, L.; VECHI, S.M.; JUNIOR, C.Q. The hydration structure of the na+ and $\mathrm{k}+$ ions and the selectivity of their ionic channels. Biochimica et Biophysica Acta (BBA)-Bioenergetics, v. 1274, n. 3, p. 149-156, 1996.

DESTEXHE, A.; MAINEN, Z.F.; SEJNOWSKI, T.J. Synthesis of models for excitable membranes, synaptic transmission and neuromodulation using a common kinetic formalism. Journal of Computational Neuroscience, v. 1, n. 3, p. 195-230, 1994.

DITTRICH, M.; PATTILLO, J.M.; KING, J.D.; CHO, S.; STILES, J.R.; MERINEY, S.D. An excess-calcium-binding-site model predicts neurotransmitter release at the neuromuscular junction. Biophysical Journal, v. 104, n. 12, p. 2751-2763, 2013.

DO, M.T.H.; BEAN, B.P. Subthreshold sodium currents and pacemaking of subthalamic neurons: modulation by slow inactivation. Neuron, v. 39, n. 1, p. 109-120, 2003.

DOYLE, D.A.; CABRAL, J.M.; PFUETZNER, R.A.; KUO, A.; GULBIS, J.M.; COHEN, S.L.; CHAIT, B.T.; MACKINNON, R. The structure of the potassium channel: Molecular basis of k+ conduction and selectivity. Science, v. 280, n. 5360, p. 69-77, 1998.

DRACHMAN, D.A. Do we have brain to spare? Neurology, v. 64, n. 12, p. 2004-2005, 2005.

DRION, G.; O'LEARY, T.; MARDER, E. Ion channel degeneracy enables robust and tunable neuronal firing rates. Proceedings of the National Academy of Sciences, v. 112, n. 38, p. E5361-E5370, 2015.

EDWARDS, M.R. From a soup or a seed? Pyritic metabolic complexes in the origin of life. Trends in Ecology \& Evolution, v. 13, n. 6, p. 178-181, 1998.

EINSTEIN, A. Über die von der molekularkinetischen theorie der wärme geforderte bewegung von in ruhenden flüssigkeiten suspendierten teilchen. Annalen der Physik, v. 322, n. 8, p. 549-560, 1905. 
ERMENTROUT, B. Linearization of fi curves by adaptation. Neural Computation, v. 10, n. 7, p. 1721-1729, 1998.

ERMENTROUT, B.; PASCAL, M.; GUTKIN, B. The effects of spike frequency adaptation and negative feedback on the synchronization of neural oscillators. Neural Computation, v. 13, n. 6 , p. $1285-1310,2001$.

FEYNMAN, R.P.; LEIGHTON, R.B.; SAND, M. Lições de Física de Feynman, Volume 1. Porto Alegre: Artmed, 2008.

FINK, M.; NOBLE, D. Markov models for ion channels: versatility versus identifiability and speed. Philosophical Transactions of the Royal Society of London A: Mathematical, Physical and Engineering Sciences, v. 367, n. 1896, p. 2161-2179, 2009.

FIRTH, A.L.; REMILLARD, C.V.; PLATOSHYN, O.; FANTOZZI, I.; KO, E.A.; YUAN, J.X.J. Functional ion channels in human pulmonary artery smooth muscle cells: Voltage-dependent cation channels. Pulmonary Circulation, v. 1, n. 1, p. 48-71, 2011.

FITZHUGH, R. Mathematical models of threshold phenomena in the nerve membrane. The Bulletin of Mathematical Biophysics, v. 17, n. 4, p. 257-278, 1955.

FITZHUGH, R. A kinetic model of the conductance changes in nerve membrane. Journal of Cellular and Comparative Physiology, v. 66, n. S2, p. 111-117, 1965.

FLEIDERVISH, I.A.; FRIEDMAN, A.; GUTNICK, M.J. Slow inactivation of na+ current and slow cumulative spike adaptation in mouse and guinea-pig neocortical neurones in slices. The Journal of Physiology, v. 493, n. 1, p. 83-97, 1996.

FRICK, A.; MAGEE, J.; JOHNSTON, D. LTP is accompanied by an enhanced local excitability of pyramidal neuron dendrites. Nature Neuroscience, v. 7, n. 2, p. 126-135, 2004.

FRIGG, R.; HARTMANN, S. Models in science. In: ZALTA, E.N. (Ed.). The Stanford Encyclopedia of Philosophy. Summer 2009. Santa Clara: Metaphysics Research Lab, 2009. Disponível em: <http://plato.stanford.edu/archives/sum2009/entries/ models-science/>.

GABBIANI, F.; COX, S.J. Mathematics for Neuroscientists. Amsterdam: Elsevier Science, 2010. (Elsevier science \& technology books).

GARDNER, M. Mathematical games: The fantastic combinations of John Conway's new solitaire game "life". Scientific American, v. 223, n. 4, p. 120-123, 1970.

GEORGE, A.L. Inherited channelopathies associated with epilepsy. Epilepsy Currents, v. 4 , n. 2, p. $65-70,2004$.

GERS, Felix; GARIS, Hugo de; KORKIN, Michael. Codi-1bit : A simplified cellular automata based neuron model. In: Artificial Evolution: Third European Conference $A E$ ' 97 Nîmes, France, October 22-24, 1997 Selected Papers. Berlin: Springer, 1998. p. 315-333. 
GERSTNER, W.; KISTLER, W.M.; NAUD, R.; PANINSKI, L. Neuronal dynamics: From single neurons to networks and models of cognition. Cambridge: Cambridge University Press, 2014.

GERSTNER, W.; NAUD, R. How good are neuron models? Science, v. 326, n. 5951, p. 379-380, 2009.

GERSTNER, W.; SPREKELER, H.; DECO, G. Theory and simulation in neuroscience. Science, v. 338, n. 6103, p. 60-65, 2012.

GHASEMZADEH, M.B.; MUELLER, C.; VASUDEVAN, P. Behavioral sensitization to cocaine is associated with increased glutamate receptor trafficking to the postsynaptic density after extended withdrawal period. Neuroscience, v. 159, n. 1, p. 414-426, 2009.

GILLESPIE, D.T. Exact stochastic simulation of coupled chemical reactions. The Journal of Physical Chemistry, v. 81, n. 25, p. 2340-2361, 1977.

GOLDING, N.L.; STAFF, N.P.; SPRUSTON, N. Dendritic spikes as a mechanism for cooperative long-term potentiation. Nature, v. 418, n. 6895, p. 326-331, 2002.

GOLDSTEIN, S.A.N.; BOCKENHAUER, D.; O'KELLY, I.; ZILBERBERG, N. Potassium leak channels and the KCNK family of two-P-domain subunits. Nature Reviews Neuroscience, v. 2, n. 3, p. 175-184, 2001.

GREENBERG, J.M.; HASTINGS, S.P. Spatial patterns for discrete models of diffusion in excitable media. SIAM Journal on Applied Mathematics, v. 34, n. 3, p. 515-523, 1978.

GREGER, R.; WINDHORST, U. Comprehensive Human Physiology: From Cellular Mechanisms to Integration. Berlin: Springer, 2013.

GRIMM, V.; RAILSBACK, S.F. Individual-based modeling and ecology. Princeton: Princeton University Press, 2013.

GUCKENHEIMER, J.; LABOURIAU, J.S. Bifurcation of the hodgkin and huxley equations: a new twist. Bulletin of Mathematical Biology, v. 55, n. 5, p. 937-952, 1993.

HÄUSSER, M. Storing memories in dendritic channels. Nature Neuroscience, v. 7, n. 2, p. 98-100, 2004.

HAYKIN, S.O. Neural Networks and Learning Machines. New York: Pearson, 2011.

HE, L.; WU, L. The debate on the kiss-and-run fusion at synapses. Trends in Neurosciences, v. 30, n. 9, p. 447-455, 2007.

HEGINBOTHAM, L.; LU, Z.; ABRAMSON, T.; MACKINNON, R. Mutations in the k+ channel signature sequence. Biophysical Journal, v. 66, n. 4, p. 1061-1067, 1994.

HEIMBURG, T. Thermal Biophysics of Membranes. Weinheim: Wiley, 2008. (Tutorials in Biophysics). 
HEIMBURG, T.; JACKSON, A.D. On soliton propagation in biomembranes and nerves. Proceedings of the National Academy of Sciences of the United States of America, v. 102, n. 28, p. 9790-9795, 2005.

HENLEY, J.M.; WILKINSON, K.A. AMPA receptor trafficking and the mechanisms underlying synaptic plasticity and cognitive aging. Dialogues in Clinical Neuroscience, v. 15 , n. 1, p. 11-27, 2013.

HERZ, A.V.M.; GOLLISCH, T.; MACHENS, C.K.; JAEGER, D. Modeling single-neuron dynamics and computations: a balance of detail and abstraction. Science, v. 314, n. 5796, p. 80-85, 2006.

HILLE, B. Ion Channels of Excitable Membranes. Sunderland: Sinauer, 2001.

HIRTH, F.; REICHERT, H. Basic nervous system types: One or many? In: KAAS, J.H. (Ed.). Evolution of Nervous Systems. Oxford: Academic Press, 2007. p. 55 - 72.

HODGKIN, A.L.; HUXLEY, A.F. A quantitative description of membrane current and its application to conduction and excitation in nerve. The Journal of Physiology, v. 117, n. 4, p. 500-544, 1952.

HODGKIN, A.L.; HUXLEY, A.F.; KATZ, B. Measurement of current-voltage relations in the membrane of the giant axon of loligo. The Journal of Physiology, v. 116, n. 4, p. 424-448, 1952.

HODGKIN, A.L.; KEYNES, R.D. The potassium permeability of a giant nerve fibre. The Journal of Physiology, v. 128, n. 1, p. 61-88, 1955.

HOFMANN, M.I. A cellular automaton model based on cortical physiology. Complex Systems, v. 1, n. 1, p. 187-202, 1987.

HOLLAND, J.H. Emergence: From Chaos to Order. Oxford: Oxford University Press, 2000. HONORÉ, T.; LAURIDSEN, J.; KROGSGAARD-LARSEN, P. The binding of [3H]AMPA, a structural analogue of glutamic acid, to rat brain membranes. Journal of Neurochemistry, v. 38, n. 1 , p. $173-178,1982$.

HOWARTH, J.V. Heat production in non-myelinated nerves. Philosophical Transactions of the Royal Society of London B: Biological Sciences, v. 270, n. 908, p. 425-432, 1975.

HOWARTH, J.V.; KEYNES, R.D.; RITCHIE, J.M. The origin of the initial heat associated with a single impulse in mammalian non-myelinated nerve fibres. The Journal of Physiology, v. 194, n. 3, p. 745-793, 1968.

HUXLEY, A. From overshoot to voltage clamp. Trends in Neurosciences, v. 25, n. 11, p. 553-558, 2002.

ILACHINSKI, A. Cellular Automata: A Discrete Universe. River Edge: World Scientific, 2001. 
IZHIKEVICH, E.M. Simple model of spiking neurons. IEEE Transactions on Neural Networks, v. 14, n. 6, p. 1569-1572, 2003.

IZHIKEVICH, E.M. Dynamical systems in neuroscience. Cambridge, Mass.: MIT Press, 2007.

JACKSON, W.F. Ion channels and vascular tone. Hypertension, v. 35, n. 1, p. 173-178, 2000.

JOHNSON, E.A.; MCKINNON, M.G. The differential effect of quinidine and pyrilamine on the myocardial action potential at various rates of stimulation. Journal of Pharmacology and Experimental Therapeutics, v. 120, n. 4, p. 460-468, 1957.

JOHNSTON, D.; WU, S.M.S. Foundations of Cellular Neurophysiology. Cambridge, Mass.: MIT Press, 1995.

KANDEL, E.R.; SCHWARTZ, J.H.; JESSELL, T.M.; SIEGELBAUM, S.A.; HUDSPETH, A.J. Principles of Neural Science. New York: McGraw-Hill Education, 2012. (Principles of Neural Science).

KANG, S.; KANG, K.; LEE, K.; BACK, K. Characterization of tryptamine 5-hydroxylase and serotonin synthesis in rice plants. Plant Cell Reports, v. 26, n. 11, p. 2009-2015, 2007.

KAUFMAN, I.K.; MCCLINTOCK, P.V.E.; EISENBERG, R.S. Coulomb blockade model of permeation and selectivity in biological ion channels. New Journal of Physics, v. 17, n. 8, 083021, 15 páginas, 2015.

KENNEDY, M.B. Signal-processing machines at the postsynaptic density. Science, v. 290, n. 5492, p. 750-754, 2000.

KEW, J.N.C.; DAVIES, C.H. Ion Channels: From Structure to Function. Oxford: Oxford University Press, 2010.

KISHIDA, H; SURAWICZ, B; FU, L T. Effects of $\mathrm{K}+$ and $\mathrm{K}+$-induced polarization on $(\mathrm{dV} / \mathrm{dt}$ )max, threshold potential, and membrane input resistance in guinea pig and cat ventricular myocardium. Circulation Research, v. 44, n. 6, p. 800-814, 1979.

KLEPPE, I.C.; ROBINSON, H.P.C. Determining the activation time course of synaptic AMPA receptors from openings of colocalized NMDA receptors. Biophysical Journal, v. 77, n. 3, p. 1418-1427, 1999.

$\mathrm{KOCH}, \mathrm{C}$. Biophysics of Computation: Information Processing in Single Neurons. New York: Oxford University Press, 1999. (Computational Neuroscience Series).

KOCH, C.; SEGEV, I. Methods in Neuronal Modeling: From lons to Networks. Cambridge, Mass.: MIT Press, 1998.

KUHN, T.S.; HACKING, I. The Structure of Scientific Revolutions: 50th Anniversary Edition. Chicago: University of Chicago Press, 2012. 
LA CAMERA, G.; RAUCH, A.; THURBON, D.; LÜSCHER, H.R.; SENN, W.; FUSI, S. Multiple time scales of temporal response in pyramidal and fast spiking cortical neurons. Journal of Neurophysiology, v. 96, n. 6, p. 3448-3464, 2006.

LAIRD, D.W. Life cycle of connexins in health and disease. Biochemical Journal, v. 394, n. 3, p. 527-543, 2006.

LANGTON, C.G. Artificial Life: An Overview. Cambridge, Mass.: MIT Press, 1997.

LAYTON, H.E.; WEINSTEIN, A.M. Membrane Transport and Renal Physiology. New York: Springer, 2002.

LETICHEVSKII, A.A.; RESHODKO, L.V. Norbert Wiener's theory of the activity of excitable media. Cybernetics, v. 8, n. 5, p. 856-864, 1972.

LEVITT, D.G. Modeling of ion channels. The Journal of General Physiology, v. 113, n. 6, p. 789-794, 1999.

LOEB, G.E. Optimal isn't good enough. Biological Cybernetics, v. 106, n. 11, p. 757-765, 2012.

LOVEJOY, D.A. Neuroendocrinology: An Integrated Approach. Chichester: Wiley, 2005.

LOWEN, S.B.; CASH, S.S.; POO, M.; TEICH, M.C. Quantal neurotransmitter secretion rate exhibits fractal behavior. The Journal of Neuroscience, v. 17, n. 15, p. 5666-5677, 1997.

LOWEN, S.B.; LIEBOVITCH, L.S.; WHITE, J.A. Fractal ion-channel behavior generates fractal firing patterns in neuronal models. Physical Review E, v. 59, n. 5, p. 5970-5980, 1999.

LUDWIG, M. Dendritic Neurotransmitter Release. New York: Springer, 2007.

MACDONALD, P.E.; RORSMAN, P. Oscillations, intercellular coupling, and insulin secretion in pancreatic $\beta$ cells. PLoS Biology, v. 4, n. 2, p. 167-171, 2006.

MACDONALD, P.E.; WHEELER, M.B. Voltage-dependent K+ channels in pancreatic beta cells: role, regulation and potential as therapeutic targets. Diabetologia, v. 46, n. 8, p. 1046-1062, 2003.

MACKINNON, R. Potassium channels. FEBS Letters, v. 555, n. 1, p. 62-65, 2003.

MAFFEO, C.; BHATTACHARYA, S.; YOO, J.; WELLS, D.; AKSIMENTIEV, A. Modeling and simulation of ion channels. Chemical reviews, v. 112, n. 12, p. 6250-6284, 2012.

MARKRAM, H. The blue brain project. Nature Reviews Neuroscience, v. 7, n. 2, p. 153-160, 2006.

MARTINS, A.; MONTEIRO, L.H.A. Frequency transitions in synchronized neural networks. Communications in Nonlinear Science and Numerical Simulation, v. 18, n. 7, p. 1786-1791, 2013. 
MASSON, J.; SAGNE, C.; HAMON, M. e; MESTIKAWY, S. El. Neurotransmitter transporters in the central nervous system. Pharmacological Reviews, v. 51, n. 3, p. 439-464, 1999.

MCCLELLAND, J.L.; MCNAUGHTON, B.L.; O'REILLY, R.C. Why there are complementary learning systems in the hippocampus and neocortex: insights from the successes and failures of connectionist models of learning and memory. Psychological Review, v. 102, n. 3, p. 419-457, 1995.

MCCULLOCH, W.S.; PITTS, W. A logical calculus of the ideas immanent in nervous activity. The Bulletin of Mathematical Biophysics, v. 5, n. 4, p. 115-133, 1943.

MCGILCHRIST, I. The Master and His Emissary: The Divided Brain and the Making of the Western World. New Haven: Yale University Press, 2009.

MEADOWS, D.H.; WRIGHT, D. Thinking in Systems: A Primer. London: Earthscan, 2008.

MEINRENKEN, C.J.; BORST, J.G.G.; SAKMANN, B. Calcium secretion coupling at calyx of held governed by nonuniform channel-vesicle topography. The Journal of Neuroscience, v. 22 , n. 5 , p. $1648-1667,2002$.

MEYER, K.H. Contributions to the theory of narcosis. Transactions of the Faraday Society, v. 33, p. 1062-1064, 1937.

MILLAR, I.D.; BRUCE, J.I.E.; BROWN, P.D. Ion channel diversity, channel expression and function in the choroid plexuses. Cerebrospinal Fluid Research, v. 4, n. 1, 16 páginas, 2007.

MILLER, C. Ion channels: doing hard chemistry with hard ions. Current Opinion in Chemical Biology, v. 4, n. 2, p. 148-151, 2000.

MIZUSEKI, K.; SIROTA, A.; PASTALKOVA, E.; BUZSÁKI, G. Multiunit recordings from the rat hippocampus made during open field foraging. 2009. Acesso em 18-04-2016. Disponível em: <http://dx.doi.org/10.6080/K0Z60KZ9>.

MIZUSEKI, K.; SIROTA, A.; PASTALKOVA, E.; BUZSÁKI, G. Theta oscillations provide temporal windows for local circuit computation in the entorhinal-hippocampal loop. Neuron, v. 64 , n. 2, p. 267-280, 2009.

MONTEIRO, L.H.A. Sistemas dinâmicos. São Paulo: Editora Livraria da Física, 2011.

MOROZ, L.L.; KOCOT, K. M.; CITARELLA, M. R.; DOSUNG, S.; NOREKIAN, T. P.; POVOLOTSKAYA, I. S.; GRIGORENKO, A. P.; DAILEY, C.; BEREZIKOV, E.; BUCKLEY, K. M.; PTITSYN, A.; RESHETOV, D.; MUKHERJEE, K.; MOROZ, T. P.; BOBKOVA, Y.; YU, F.; KAPITONOV, V. V.; JURKA, J.; BOBKOV, Y. V.; SWORE, J. J.; GIRARDO, D. O.; FODOR, A.; GUSEV, F.; SANFORD, R.; BRUDERS, R.; KITTLER, E.; MILLS, C. E.; RAST, J. P.; DERELLE, R.; SOLOVYEV, V. V.; KONDRASHOV, F. A.; SWALLA, B. J.; SWEEDLER, J. V.; ROGAEV, E. I.; HALANYCH, K. M.; KOHN, A. B. The ctenophore genome and the evolutionary origins of neural systems. Nature, v. 510, n. 7503, p. 109-114, 2014. 
MOROZ, L. L. On the independent origins of complex brains and neurons. Brain, Behavior and Evolution, v. 74, n. 3, p. 177-190, 2009.

MULLEY, J.C.; SCHEFFER, I.E.; PETROU, S.; BERKOVIC, S.F. Channelopathies as a genetic cause of epilepsy. Current Opinion in Neurology, v. 16, n. 2, p. 171-176, 2003.

NARAHASHI, T. The properties of insect axons. In: BEAMENT, J.W.L.; TREHERNE, J.E.; WIGGLESWORTH, V.B. (Ed.). Advances in Insect Physiology. [S.I.]: Academic Press, 1963, (Advances in Insect Physiology, v. 1). p. 175 - 256.

NEISHABOURI, A.; FAISAL, A. A. Saltatory conduction in unmyelinated axons: clustering of na+ channels on lipid rafts enables micro-saltatory conduction in c-fibers. Frontiers in Neuroanatomy, v. 8, 10 páginas, 2014.

NEVES, G.; COOKE, S.F.; BLISS, T.V.P. Synaptic plasticity, memory and the hippocampus: a neural network approach to causality. Nature Reviews Neuroscience, v. 9, n. 1, p. 65-75, 2008.

NIELSEN, M.S.; L.A., Nygaard; SORGEN, P.L.; VERMA, V.; DELMAR, M.; HOLSTEINRATHLOU, N. Gap junctions. In: Comprehensive Physiology. Hoboken: Wiley Online Library, 2012. p. 1981-2035.

NIVEN, J.E.; LAUGHLIN, S.B. Energy limitation as a selective pressure on the evolution of sensory systems. Journal of Experimental Biology, v. 211, n. 11, p. 1792-1804, 2008.

NOEBELS, J.L.; AVOLI, M.; ROGAWSKI, M.A.; OLSEN, R.W.; DELGADO-ESCUETA, A.V. Jasper's Basic Mechanisms of the Epilepsies. Oxford: Oxford University Press, 2012. (Contemporary Neurology Series).

O'BRIEN, R.J.; LAU, L.F.; HUGANIR, R.L. Molecular mechanisms of glutamate receptor clustering at excitatory synapses. Current Opinion in Neurobiology, v. 8, n. 3, p. 364-369, 1998.

OLIVERA, B.M.; MILJANICH, G.P.; RAMACHANDRAN, J.; ADAMS, M.E. Calcium channel diversity and neurotransmitter release: the $\omega$-conotoxins and $\omega$-agatoxins. Annual Review of Biochemistry, v. 63, n. 1, p. 823-867, 1994.

O'REILLY, R.C.; MUNAKATA, Y. Computational Explorations in Cognitive Neuroscience: Understanding the Mind by Simulating the Brain. Cambridge, Mass.: MIT Press, 2000.

PAAS, Y. The macro-and microarchitectures of the ligand-binding domain of glutamate receptors. Trends in Neurosciences, v. 21, n. 3, p. 117-125, 1998.

PAKKENBERG, B.; PELVIG, D.; MARNER, L.; BUNDGAARD, M. J.; GUNDERSEN, H.J.G.; NYENGAARD, J.R.; REGEUR, L. Aging and the human neocortex. Experimental Gerontology, v. 38, n. 1, p. 95-99, 2003.

PAN, B.; ZUCKER, R.S. A general model of synaptic transmission and short-term plasticity. Neuron, v. 62, n. 4, p. 539-554, 2009. 
PATRICK, G.L. An Introduction to Medicinal Chemistry. Oxford: Oxford University Press, 2013.

PĂUN, G.; ROZENBERG, G. A guide to membrane computing. Theoretical Computer Science, v. 287, n. 1, p. 73-100, 2002.

PELAEZ, J.R.; ANDINA, D. Do biological synapses perform probabilistic computations? Neurocomputing, v. 114, p. 24-31, 2013.

PENDYAM, S.; MOHAN, A.; KALIVAS, P.W.; NAIR, S.S. Computational model of extracellular glutamate in the nucleus accumbens incorporates neuroadaptations by chronic cocaine. Neuroscience, v. 158, n. 4, p. 1266-1276, 2009.

PHILLIPS, G.R.; HUANG, J.K.; WANG, Y.; TANAKA, H.; SHAPIRO, L.; ZHANG, W.; SHAN, W.; ARNDT, K.; FRANK, M.; GORDON, R.E.; GAWINOWICZ, M.; ZHAO, Y.; COLMAN, D.R. The presynaptic particle web: ultrastructure, composition, dissolution, and reconstitution. Neuron, v. 32, n. 1, p. 63-77, 2001.

PINKER, S. The Language Instinct: How The Mind Creates Language. New York: Harper Perennial, 1995.

PLOPPER, G.; SHARP, D.; SIKORSKI, E. Lewin's Cells. Burlington: Jones \& Bartlett Learning, LLC, 2013.

PRENTICE, S.D.; PATLA, A.E.; STACEY, D.A. Artificial neural network model for the generation of muscle activation patterns for human locomotion. Journal of Electromyography and Kinesiology, v. 11, n. 1, p. 19-30, 2001.

PURVES, D.; AUGUSTINE, G.J.; FITZPATRICK, D.; HALL, W.C.; LAMANTIA, A.S.; WHITE, L.E. Neuroscience. Sunderland: Sinauer, 2012.

QUINN, D.M. Acetylcholinesterase: enzyme structure, reaction dynamics, and virtual transition states. Chemical Reviews, v. 87, n. 5, p. 955-979, 1987.

RABINOVICH, M.I.; VARONA, P.; SELVERSTON, A.I.; ABARBANEL, H.D.I. Dynamical principles in neuroscience. Reviews of Modern Physics, v. 78, n. 4, p. 1213-1265, 2006.

RAILSBACK, S.F.; GRIMM, V. Agent-Based and Individual-Based Modeling: A Practical Introduction. Princeton: Princeton University Press, 2011.

RALL, W. Distinguishing theoretical synaptic potentials computed for different somadendritic distribuitions of synaptic input. Journal of Neurophysiology, v. 30, n. 5, p. 1138-1168, 1967.

RALL, W. Distributions of potential in cylindrical coordinates and time constants for a membrane cylinder. Biophysical Journal, v. 9, n. 12, p. 1509-1541, 1969.

RALL, W. Time constants and electrotonic length of membrane cylinders and neurons. Biophysical Journal, v. 9, n. 12, p. 1483-1508, 1969. 
RAMACHANDRAN, V.S. Phantoms in the Brain: Probing the Mysteries of the Human Mind. New York: William Morrow, 1998.

RANGANATHAN, R. Evolutionary origins of ion channels. Proceedings of the National Academy of Sciences of the United States of America, v. 91, n. 9, p. 3484-3486, 1994.

RHOADES, R.; BELL, D.R. Medical Physiology: Principles for Clinical Medicine. Philadelphia: Lippincott Williams \& Wilkins, 2009.

RIGATOS, G. Advanced Models of Neural Networks: Nonlinear Dynamics and Stochasticity in Biological Neurons. Berlin: Springer, 2014.

RIZZOLI, S.O.; BETZ, W.J. Synaptic vesicle pools. Nature Reviews Neuroscience, v. 6, n. 1, p. 57-69, 2005.

ROGAWSKI, M.A. Revisiting ampa receptors as an antiepileptic drug target. Epilepsy Currents, v. 11, n. 2, p. 56-63, 2011.

ROJAS, R. Neural Networks: A Systematic Introduction. Berlin: Springer, 2013.

ROSENBLATT, F. The perceptron, a perceiving and recognizing automaton. Buffalo, 1957.

ROTH, A.; HÄUSSER, M. Electrical properties of dendrites relevant to dendritic transmitter release. In: Dendritic Neurotransmitter Release. Berlin: Springer, 2005. p. 55-67.

ROTH, B.L. The Serotonin Receptors: From Molecular Pharmacology to Human Therapeutics. Totowa, N.J.: Humana Press, 2008. (The Receptors).

ROTH, G.; DICKE, U. Evolution of the brain and intelligence. Trends in Cognitive Sciences, v. 9 , n. 5, p. 250-257, 2005.

ROUX, B. Theoretical and computational models of ion channels. Current Opinion in Structural Biology, v. 12, n. 2, p. 182-189, 2002.

ROUX, B.; ALLEN, T.; BERNECHE, S.; IM, W. Theoretical and computational models of biological ion channels. Quarterly Reviews of Biophysics, v. 37, n. 1, p. 15-103, 2004.

RUDY, Y. Molecular basis of cardiac action potential repolarization. Annals of the New York Academy of Sciences, v. 1123, n. 1, p. 113-118, 2008.

SAKARYA, O.; ARMSTRONG, K.A.; ADAMSKA, M.; ADAMSKI, M.; WANG, I.; TIDOR, B.; DEGNAN, B.M.; OAKLEY, T.H.; KOSIK, K.S. A post-synaptic scaffold at the origin of the animal kingdom. PLoS one, v. 2, n. 6, e506, 9 páginas, 2007.

SAKMANN, B.; NEHER, E. Patch clamp techniques for studying ionic channels in excitable membranes. Annual Review of Physiology, v. 46, n. 1, p. 455-472, 1984.

SANSOM, M.S.; BALL, F.G.; KERRY, C.J.; MCGEE, R.; RAMSEY, R.L.; USHERWOOD, P.N. Markov, fractal, diffusion, and related models of ion channel gating. a comparison with experimental data from two ion channels. Biophysical Journal, v. 56, n. 6, p. 1229-1243, 1989. 
SAYAMA, H. Introduction to the Modeling and Analysis of Complex Systems. Geneseo: SUNY, 2015.

SCHWARZ, S.K.W.; PUIL, E. Analgesic and sedative concentrations of lignocaine shunt tonic and burst firing in thalamocortical neurones. British Journal of Pharmacology, v. 124, n. 8, p. 1633-1642, 1998.

SCIMEMI, A.; BEATO, M. Determining the neurotransmitter concentration profile at active synapses. Molecular Neurobiology, v. 40, n. 3, p. 289-306, 2009.

SHENG, J.; HE, L.; ZHENG, H.; XUE, L.; LUO, F.; SHIN, W.; SUN, T.; KUNER, T.; YUE, D.T.; WU, L. Calcium-channel number critically influences synaptic strength and plasticity at the active zone. Nature Neuroscience, v. 15, n. 7, p. 998-1006, 2012.

SIGEL, A.; SIGEL, H.; SIGEL, R.K.O. The Alkali Metal lons: Their Role for Life. Berlin: Springer, 2016. (Metal lons in Life Sciences).

SKAUGEN, E.; WALLØE, L. Firing behaviour in a stochastic nerve membrane model based upon the hodgkin-huxley equations. Acta Physiologica Scandinavica, v. 107, n. 4, p. 343-363, 1979.

SOLTANI, A.; WANG, X. Synaptic computation underlying probabilistic inference. Nature Neuroscience, v. 13, n. 1, p. 112-119, 2010.

STACHOWIAK, H. Allgemeine Modelltheorie. Vienna: Springer, 1973.

STAFSTROM, C.E.; SCHWINDT, P.C.; CRILL, W.E. Repetitive firing in layer V neurons from cat neocortex in vitro. The Journal of Neurophysiology, v. 52, n. 2, p. 264-277, 1984.

STANLEY, E.F. The calcium channel and the organization of the presynaptic transmitter release face. Trends in Neurosciences, v. 20, n. 9, p. 404-409, 1997.

STEIN, A.; RADHAKRISHNAN, A.; RIEDEL, D.; FASSHAUER, D.; JAHN, R. Synaptotagmin activates membrane fusion through a ca2+-dependent trans interaction with phospholipids. Nature Structural \& Molecular Biology, v. 14, n. 10, p. 904-911, 2007.

STERRATT, D.; GRAHAM, B.; GILLIES, A.; WILLSHAW, D. Principles of Computational Modelling in Neuroscience. Cambridge: Cambridge University Press, 2011.

STRONG, M.; CHANDY, K. G.; GUTMAN, G. A. Molecular evolution of voltage-sensitive ion channel genes: on the origins of electrical excitability. Molecular Biology and Evolution, v. 10, n. 1, p. 221-242, 1993.

SÜDHOF, T.C. The synaptic vesicle cycle: a cascade of protein-protein interactions. Nature, v. 375, n. 6533, p. 645-653, 1995.

SÜDHOF, T.C. The synaptic vesicle cycle. Annual Review of Neuroscience, v. 27, p. 509-547, 2004.

SÜDHOF, T.C. The presynaptic active zone. Neuron, v. 75, n. 1, p. 11-25, 2012. 
SÜDHOF, T.C. A molecular machine for neurotransmitter release: synaptotagmin and beyond. Nature Medicine, v. 19, n. 10, p. 1227-1231, 2013.

SÜDHOF, T.C. Neurotransmitter release: the last millisecond in the life of a synaptic vesicle. Neuron, v. 80, n. 3, p. 675-690, 2013.

SUTTON, R.B.; FASSHAUER, D.; JAHN, R.; BRUNGER, A.T. Crystal structure of a SNARE complex involved in synaptic exocytosis at $2.4 \AA$ resolution. Nature, v. 395, n. 6700 , p. 347-353, 1998.

TANAKA, J.; MATSUZAKI, M.; TARUSAWA, E.; MOMIYAMA, A.; MOLNAR, E.; KASAI, H.; SHIGEMOTO, R. Number and density of ampa receptors in single synapses in immature cerebellum. The Journal of Neuroscience, v. 25, n. 4, p. 799-807, 2005.

TASAKI, I.; BYRNE, P.M. Heat production associated with a propagated impulse in bullfrog myelinated nerve fibers. The Japanese Journal of Physiology, v. 42, n. 5, p. 805-813, 1992.

TASAKI, I.; KUSANO, K.; BYRNE, P.M. Rapid mechanical and thermal changes in the garfish olfactory nerve associated with a propagated impulse. Biophysical Journal, v. 55, n. 6, p. 1033-1040, 1989.

TURING, A.M. The chemical basis of morphogenesis. Philosophical Transactions of the Royal Society of London. Series B, Biological Sciences, v. 237, n. 641, p. 37-72, 1952.

TURNER, K.M.; BURGOYNE, R.D.; MORGAN, A. Protein phosphorylation and the regulation of synaptic membrane traffic. Trends in Neurosciences, v. 22, n. 10, p. 459-464, 1999.

UHRMACHER, A.M.; WEYNS, D. Multi-Agent systems: Simulation and applications. Boca Raton: CRC press, 2009.

VAN DER LOOS, H.; GLASER, E.M. Autapses in neocortex cerebri: synapses between a pyramidal cell's axon and its own dendrites. Brain Research, v. 48, p. 355-360, 1972.

Van Winkle, L.J. Biomembrane Transport. Amsterdam: Elsevier Science, 1999.

VAZIRI, A.; PLENIO, M.B. Quantum coherence in ion channels: resonances, transport and verification. New Journal of Physics, v. 12, n. 8, 085001, 18 páginas, 2010.

VENKATESAN, K.; LIU, Y.; GOLDFARB, M. Fast-onset long-term open-state block of sodium channels by a-type fhfs mediates classical spike accommodation in hippocampal pyramidal neurons. The Journal of Neuroscience, v. 34, n. 48, p. 16126-16139, 2014.

VOLK, D. Spiking behavior and epileptiform oscillations in a discrete model of cortical neural networks. Theory in Biosciences, v. 120, n. 1, p. 33-44, 2001.

WAGNER, E.K.; HEWLETT, M.J.; BLOOM, D.C.; CAMERINI, D. Basic Virology. Malden: Wiley, 2009. 
WIENER, N. Cybernetics Or Control and Communication in the Animal and the Machine. Cambridge, Mass.: MIT Press, 1965. (MIT paperback series).

WIENER, N.; ROSENBLUETH, A. The mathematical formulation of the problem of conduction of impulses in a network of connected excitable elements, specifically in cardiac muscle. Archivos del Instituto de Cardiologia de Mexico., v. 16, n. 3, p. 205-265, 1946.

WILENSKY, U.; RAND, W. An Introduction to Agent-Based Modeling: Modeling Natural, Social, and Engineered Complex Systems with NetLogo. Cambridge, Mass.: MIT Press, 2015.

WOLFRAM, S. Statistical mechanics of cellular automata. Reviews of Modern Physics, v. 55, n. 3, p. 601-644, Jul 1983.

WU, X.; XUE, L.; MOHAN, R.; PARADISO, K.; GILLIS, K.D.; WU, L. The origin of quantal size variation: vesicular glutamate concentration plays a significant role. The Journal of Neuroscience, v. 27, n. 11, p. 3046-3056, 2007.

ZEBERG, H.; ROBINSON, H.P.C.; ÅRHEM, P. Density of voltage-gated potassium channels is a bifurcation parameter in pyramidal neurons. Journal of Neurophysiology, v. 113 , n. 2, p. 537-549, 2015.

ZHENG, J.; TRUDEAU, M.C. Handbook of Ion Channels. Boca Raton: CRC Press, 2015.

ZHOU, Y.; MACKINNON, R. The occupancy of ions in the k+ selectivity filter: Charge balance and coupling of ion binding to a protein conformational change underlie high conduction rates. Journal of Molecular Biology, v. 333, n. 5, p. 965-975, 2003.

ZIFF, E.B. Enlightening the postsynaptic density. Neuron, v. 19, n. 6, p. 1163-1174, 1997. 